\title{
Characterisation of Vti1b and Vti1a proteins and generation of knock-out mice
}

\author{
Dissertation \\ zur Erlangung des Doktorgrades \\ der Matematisch-Naturwissenschaftlichen Fakultäten \\ der Georg-August-Universität zu Göttingen
}

\author{
vorgelegt von \\ Vadim Atlachkine \\ aus Kwitok / \\ Russische Föderation
}

Göttingen 2002 
Atlachkine Vadim:

Characterisation of Vti1b and Vti1a proteins and generation of knock-out mice

D7

Referent:

Prof. Dr. Kurt von Figura

Korreferent:

Prof. Dr. G. Gottschalk

Tag der mündlichen Prüfung:

20.06.02 
To my parents and my daughter Anisja 





\section{Contents}

\begin{tabular}{|llr|}
\hline $\mathbf{1}$ & Introduction & $\mathbf{1}$ \\
\hline $\mathbf{1 . 1}$ & Membrane trafficking & $\mathbf{1}$ \\
\hline $\mathbf{1 . 2}$ & Molecular mechanisms of membrane transport & $\mathbf{4}$ \\
\hline $\mathbf{1 . 3}$ & SNARE proteins & $\mathbf{5}$ \\
\hline $\mathbf{1 . 4}$ & Classification of SNARE proteins & $\mathbf{8}$ \\
\hline $\mathbf{1 . 5}$ & Subcellular distribution of SNAREs & $\mathbf{9}$ \\
\hline $\mathbf{1 . 6}$ & Function of SNAREs & $\mathbf{1 1}$ \\
\hline $\mathbf{1 . 7}$ & Vti1 proteins & $\mathbf{1 4}$ \\
\hline 1.7 .1 & Yeast Vtilp & 14 \\
\hline 1.7 .2 & Vtil homologs & 15 \\
\hline 1.7 .2 .1 & Mammalian Vtilb & 16 \\
\hline 1.7 .2 .2 & Mammalian Vtila & 16 \\
\hline $\mathbf{1 . 8}$ & Targeted gene replacement as tool for studies of mammalian protein & \\
\hline & function & $\mathbf{1 7}$ \\
\hline $\mathbf{2}$ & Aim of the work & $\mathbf{1 9}$ \\
\hline $\mathbf{3}$ & Materials and methods & $\mathbf{2 0}$ \\
\hline 3.1 & Materials & $\mathbf{2 0}$ \\
\hline 3.1 .1 & Devices & 20 \\
\hline 3.1 .2 & Materials & 21 \\
\hline 3.1 .3 & Chemicals & 26 \\
\hline 3.1 .4 & Detergents & 26 \\
\hline 3.1 .5 & Enzymes and nucleotides & 26 \\
\hline 3.1 .6 & Kits for treating of DNA, RNA and proteins \\
\hline 3.1 .7 & Proteins, protease inhibitors and protein standards \\
\hline 3.1 .8 & Antibodies & 26 \\
\hline 3.1 .8 .1 & Primary antibodies & 26 \\
\hline 3.1 .8 .2 & Secondary antibodies & 26 \\
\hline 3.1 .9 & Radioactive substances & 26 \\
\hline 3.1 .10 & Vectors and DNA standard & \\
\hline 3.1 .11 & Bacterial strains and embryonic stem cells & \\
\hline & & 26 \\
\hline
\end{tabular}


\begin{tabular}{lll}
\hline 3.1 .12 & Antibiotics & 26 \\
\hline
\end{tabular}

\begin{tabular}{llr}
\hline .1 .13 & Mouse strains & 27 \\
\hline
\end{tabular}

\begin{tabular}{llr}
\hline 3.1 .14 & Frequently used buffers and stock solutions & 27 \\
\hline
\end{tabular}

\begin{tabular}{lll}
3.1 .15 & Media for cultivation of bacteria and phage $\lambda$ & 28 \\
\hline
\end{tabular}

\begin{tabular}{llll}
\hline 3.1 .16 & Media for eucaryotic cell culture and solutions for treating of these cells & 28 \\
\hline
\end{tabular}

\begin{tabular}{lll}
$3.1 .17 \quad$ Hardware and software & 30 \\
\hline 3.2
\end{tabular}

$3.2 \quad$ Methods of molecular biology 31

\begin{tabular}{lll}
\hline 3.2 .1 & Methods of DNA treatment & 31 \\
\hline
\end{tabular}

\begin{tabular}{|lll}
\hline 3.2 .1 .1 & Precipitation of DNA with ethanol & 31 \\
\hline
\end{tabular}

3.2.1.2 Phenol/chloroform/isoamylalcohol extraction of DNA 31

3.2 .1 .3 Determination of DNA concentration 31

3.2.1.4 Purification of DNA using Sephadex ${ }^{\circledR}$ G50 31

\begin{tabular}{lll}
3.2 .1 .5 & Restriction digestion of DNA with endonucleases & 32 \\
\hline
\end{tabular}

\begin{tabular}{|lll}
\hline 3.2 .1 .6 & DNA ligation & 33 \\
\hline 3.2 .1 .7 & Phosphatase & 33 \\
\hline
\end{tabular}

\begin{tabular}{lll}
\hline 3.2 .1 .7 & Phosphatase treatment of digested plasmid DNA & 33 \\
\hline
\end{tabular}

\begin{tabular}{lll}
3.2 .1 .8 & Site-directed mutagenesis & 33 \\
\hline
\end{tabular}

3.2 .2 DNA isolation 35

\begin{tabular}{lll}
\hline 3.2 .2 .1 & Mini preparation of plasmid DNA & 35 \\
\hline
\end{tabular}

\begin{tabular}{lll}
\hline 3.2 .2 .2 & Mini preparation of plasmid DNA (QIAGEN method) & 35 \\
\hline
\end{tabular}

\begin{tabular}{|lll}
\hline 3.2 .2 .3 & Midi preparation of plasmid DNA (QIAGEN method) & 36 \\
\hline
\end{tabular}

\begin{tabular}{lll}
\hline 3.2.2.4 & Maxi preparation of phage $\lambda$ DNA (QIAGEN method) & 37 \\
\hline
\end{tabular}

\begin{tabular}{lll}
\hline 3.2 .2 .5 & Genomic DNA isolation from mouse tissues & 38 \\
\hline
\end{tabular}

\begin{tabular}{lll}
3.2 .2 .6 & DNA isolation from embryonic stem cells & 38 \\
\hline
\end{tabular}

\begin{tabular}{lll}
\hline 3.2 .2 .7 & DNA isolation from mouse tail biopsy & 39 \\
\hline
\end{tabular}

\begin{tabular}{lll}
3.2 .3 & Agarose gel electrophoresis for DNA separation & 39 \\
\hline
\end{tabular}

\begin{tabular}{lll}
\hline $.2 .4 \quad$ Extraction of DNA fragments from agarose gels & 41 \\
\hline
\end{tabular}

\begin{tabular}{lll}
3.2 .5 & Transformation of E.coli via electroporation with plasmid DNA & 41 \\
\hline
\end{tabular}

\begin{tabular}{lll}
3.2 .6 & Cryoconservation of E.coli clones using DMSO solution & 42 \\
\hline
\end{tabular}

\begin{tabular}{lll}
3.2 .7 & DNA hybridisation techniques & 42 \\
\hline
\end{tabular}

3.2.7.1 DNA transfer to Hybond N membranes 42

3.2.7.2 DNA labelling with $\alpha-\left[{ }^{32} \mathrm{P}\right]-\mathrm{dCTP}$ (making of DNA probes) 43

3.2.7.3 Screening of phage $\lambda$ mouse genomic DNA libraries 4 
3.2.7.4 Hybridisation of HybondN membranes with radioactive labelled DNA probes

\begin{tabular}{|llr|}
\multicolumn{1}{l}{ (Amersham procedure) } & 46 \\
\hline 3.2 .8 & PCR method for DNA amplification & 47 \\
\hline 3.2 .9 & PCR on genomic DNA template for genotype analysis & 48 \\
\hline 3.2 .10 & Methods of working with RNA & 49 \\
\hline 3.2 .10 .1 & RNA extraction from mouse tissues & 49 \\
\hline 3.2 .10 .2 & Agarose gel electrophoresis for RNA separation and nothern blotting & 50 \\
\hline 3.2 .10 .3 & Hybridisation of Nothern blots & 51 \\
\hline 3.3 & Methods of cell biology and biochemistry & 53 \\
\hline 3.3 .1 & Methods for handling of eucaryotic cells & 53 \\
\hline 3.3 .1 .1 & Trypsination of cells & 53 \\
\hline 3.3 .1 .2 & Cryoconservation of cells & 53 \\
\hline 3.3 .1 .3 & Thawing and revitalising of cells & 54 \\
\hline 3.3 .1 .4 & Isolation of hepatocytes & 54 \\
\hline 3.3 .1 .5 & Preparing of mouse embryonic fibroblasts (MEF) \\
\hline 3.3 .2 & Methods of protein biochemistry & 57 \\
\hline
\end{tabular}

3.3.2.1 Preparing of tissue - and cell homogenates for enzymatic assays and western -

blot analyses

\begin{tabular}{|lll}
\hline 3.3 .2 .2 & Determination of protein concentration using Bradford reagent & 58 \\
\hline 33.33
\end{tabular}

3.3.2.3 Measuring of activities of lysosomal enzymes in cells and tissues 58

3.3.2.4 SDS - polyacrylamide - gel electrophoresis (SDS -PAGE) of proteins 60

\begin{tabular}{|lll}
\hline 3.3 .2 .5 & Semi-dry protein transfer (western - blotting) & 62 \\
\hline
\end{tabular}

3.3.2.6 Antibody - staining and enhanced chemiluminiscent (ECL) assay for protein

detection

3.3.2.7 Metabolic labelling of cells for immunoprecipitation of lysosomal protease

Cathepsin D

\begin{tabular}{lll}
$3.3 .2 .8 \quad$ Washing of pansorbin & 65 \\
\hline 3329 &
\end{tabular}

\begin{tabular}{|lll}
\hline 3.3 .2 .9 & Immunoprecipitation of metabolically labelled cathepsin D & 65 \\
\hline
\end{tabular}

\begin{tabular}{|lll}
3.3 .2 .10 & Degradation of long - live proteins by mouse hepatocytes & 66
\end{tabular}

\begin{tabular}{lll}
\hline 3.3 .2 .11 & Immunofluorescent localisation of proteins & 67 \\
\hline
\end{tabular}

\begin{tabular}{|lll}
\hline 3.3 .2 .12 & FITC-dextran uptake by mouse embryonic fibroblasts (MEF) & 69 \\
\hline
\end{tabular}

\begin{tabular}{|ll}
\hline 3.3 .2 .13 & Endocytosis of fluorescently labelled LDL \\
\hline
\end{tabular} 
3.3.2.14 Epidermal growth factor receptor (EGF-R) uptake and degradation in MEF and

cultivated hepatocytes

3.3.2.15 Uptake and degradation of ${ }^{125} \mathrm{I}$-asialofetuin in mouse hepatocytes

$4 \quad$ Results

$4.1 \quad$ Generation of Vti1b deficient mice

4.1.1 Isolation of genomic DNA for Vtilb, characterisation of Vtilb chromosomal

egion and construction of a targeting vector

\begin{tabular}{lll}
\hline $4.1 .2 \quad$ Obtaining of Vtilb null mutants & 75 \\
\hline
\end{tabular}

\begin{tabular}{lll}
\hline 4.2 & Analysis of Vti1b deficient mice & 79 \\
\hline
\end{tabular}

\begin{tabular}{lll}
\hline 4.2 .1 & The phenotypic manifestation of Vtilb deficiency & 79 \\
\hline
\end{tabular}

4.2.2 Immunofluorescent localisation of different proteins in mouse embryonic fibroblasts

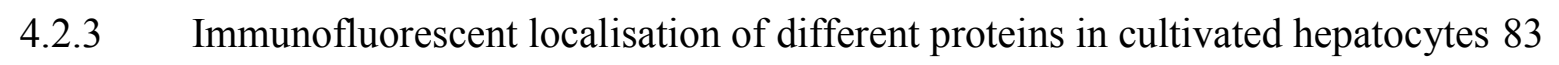

$4.2 .4 \quad$ Activities of lysosomal enzymes in serum and organs of these mice 15

$4.2 .5 \quad$ Levels of several proteins in Vtilb deficient cells and tissues 87

4.2.6 Syntaxin 8 and other SNAREs expression in Vtilb deficient cells and tissues 89

\begin{tabular}{lll}
\hline 4.2 .7 & Fluid-phase endocytosis in control and deficient MEFs & 90 \\
\hline
\end{tabular}

\begin{tabular}{lll}
\hline 4.2 .8 & Fluorescent-LDL uptake and degradation in control and knock-out MEFs & 92 \\
\hline
\end{tabular}

$4.2 .9 \quad$ EGF-R uptake and degradation in Vtilb deficient hepatocytes 93

$4.2 .10 \quad$ Uptake and degradation of ${ }^{125}$ I-asialofetuin in Vtilb deficient hepatocytes 95

4.2.11 Transport of newly synthesised cathepsin D in MEFs and cultivated hepatocytes

\begin{tabular}{rr}
\hline & 96 \\
\hline
\end{tabular}

$4.2 .12 \quad$ Rates of autophagocytosis in hepatocytes of normal size deficient mice 99

4.2.13 Electron-microscopic study of Vti1b deficient hepatocytes 101

4.3 Isolation of genomic DNA for Vtila, characterisation of the chromosomal

region of Vti1a and construction of targeting vectors 103

\begin{tabular}{|lll|}
\hline 5 & Discussion & 109 \\
\hline
\end{tabular}

5.1 Generation of deficient mice to characterise the role of Vtilb in endosomal

\begin{tabular}{ll}
\hline traffic & 109 \\
\hline
\end{tabular}

\begin{tabular}{|lll|}
\hline 5.1 .1 & Homology of mouse Vtil proteins & 109 \\
\hline
\end{tabular}

5.1.2 Phenotypic heterogeneity of Vtilb deficient mice 111

\begin{tabular}{lll}
5.1 .3 & Syntaxin 8 protein levels in deficient cells and tissues & 112 \\
\hline
\end{tabular} 
5.1.4 Retardation of endosomal cargo delivery to lysosomes in Vtilb deficient hepatocytes

5.1.5 Comparison of membrane traffic in Vtilb-deficient cells with in vitro studies of endosomal trafficking 115

5.1.6 What may be reasons for the phenotypic heterogeneity of Vtilb deficient mice?

5.1.7 Comparison of Vtilb deficiency to other knockout studies and an overview of existent organellar disease models

5.1.8 Outlook

\begin{tabular}{|llr|}
\hline 6 & Summary & 122 \\
\hline
\end{tabular}

$7 \quad$ References

123




\section{Abbreviations}

AP-1

AP-2

AP-3

AP-4

APS

ASA

ATP

BSA

cDNA

cpm

dATP

dCTP

dGTP

DMEM

DMSO

DNA

dNTP

DTT

dTTP

$\varepsilon$

E.coli

EDTA

ER

et al.

FCS

$\mathrm{h}$

HEPES

HPLC

$\mathrm{kb}$

$\mathrm{kD}$ adaptor complex 1

adaptor complex 2

adaptor complex 3

adaptor complex 4

ammonium peroxodisulfate

arylsulfatase A

adenosine triphosphate

bowine serum albumine

complimentary DNA

counts per minute

deoxy adenosine triphosphate

deoxy cytidine triphosphate

deoxy guanosine triphosphate

Dulbecco`s modified Eagle medium

dimethylsulfoxide

deoxy ribonucleic acid

deoxy ATP, CTP, GTP and TTP

dithiotreitol

deoxy thymidine triphosphate

molar extinction coefficient

Escherichia coli

disodiummethylendiamintetraacetate

endoplasmatic reticulum

et alii (lat: and others)

fetal calf serum

hour

2,4-(2-hydroxyethyl)-piperazinyl-1-ethansulfon acid

high performance liquid chromatography

kilo base pairs

kilo Dalton 


\begin{tabular}{|c|c|}
\hline LB & Luria Broth \\
\hline MEF & mouse embryonic fibroblasts \\
\hline MEM & minimal essential medium \\
\hline $\min$ & minute \\
\hline 4-MU & 4-methylumbelliferone \\
\hline MPR & mannose 6-phosphate receptor \\
\hline neo & neomycin (gentamycin G418®) \\
\hline OD & optical density \\
\hline $\mathrm{ON}$ & overnight \\
\hline PAGE & polyacrylamide gel electrophoresis \\
\hline PBS & phosphate buffered saline \\
\hline PCR & polymerase chain reaction \\
\hline rpm & rotations per minute \\
\hline RT & room temperature \\
\hline SDS & sodium dodecyl sulfate \\
\hline Taq & Termophilus aquaticus \\
\hline TBS & Tris-buffered saline \\
\hline TCA & trichlor acetic acid \\
\hline TEMED & N,N,N`,N`-tetramethylendiamine \\
\hline TGN & trans-Golgi-network \\
\hline Tris & tris-(hydroxymethyl)-aminomethane \\
\hline $\mathrm{U}$ & unit \\
\hline UV & ultra violet \\
\hline $\mathrm{v} / \mathrm{v}$ & volume to volume \\
\hline vol & volume \\
\hline $\mathrm{w} / \mathrm{v}$ & weight to volume \\
\hline $\mathrm{w} / \mathrm{w}$ & weight to weight \\
\hline wt & wild type \\
\hline
\end{tabular}

The chemical elements were abbreviated with trivial symbols 



\section{Introduction}

\subsection{Membrane trafficking}

Compartmentalization into membrane-bound organelles is one of the fundamental principles of eucaryotic cells. Membrane boundaries distinguish eucaryotic organelles from each other. However, these organelles have to exchange proteins and lipids. Plasma membrane, early endosomes, late endosomes, recycling endosomes, lysosomes, Golgi apparatus, endoplasmatic reticulum communicate through membrane enclosed vesicles containing membrane impermeable cargo molecules. Membrane material is continuously in movement; it buds and fuses, transferring cargo from one cellular compartment to another. Transport vesicles are essential intermediates maintaining structural integrity and function of organelles.

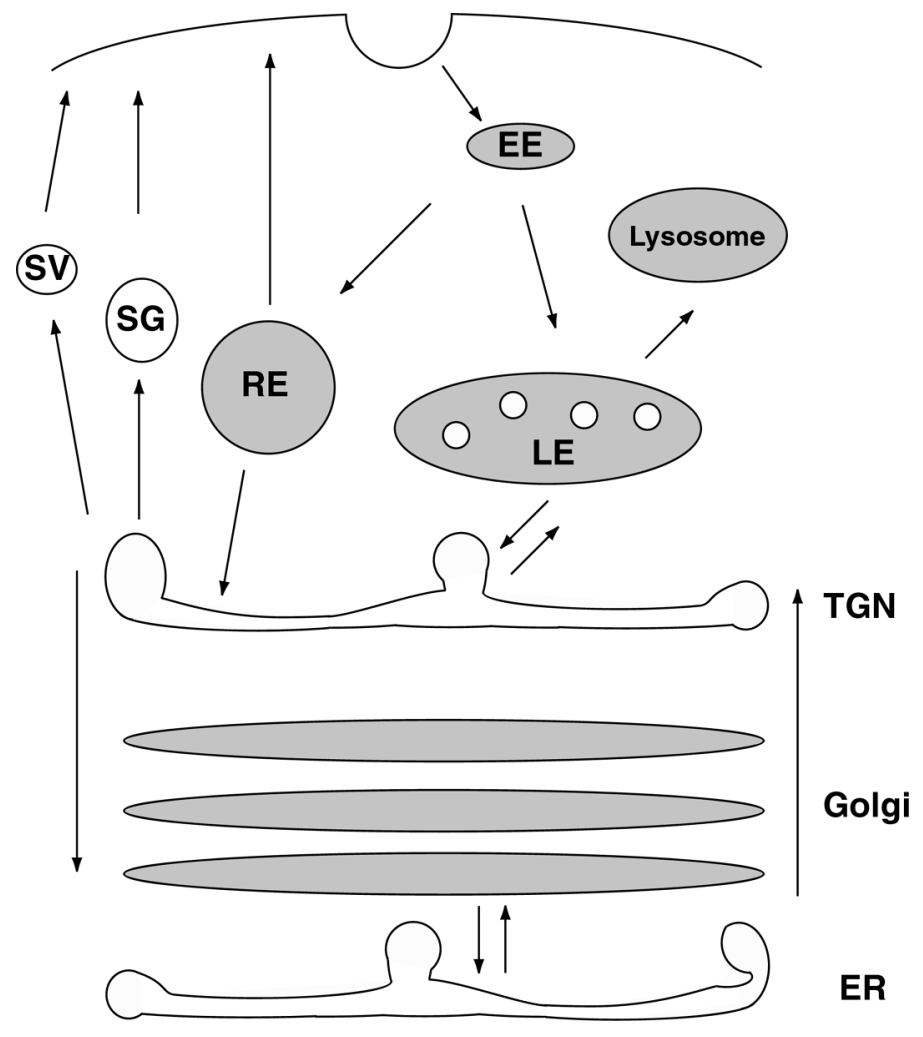

Figure 1: Schema of membrane trafficking pathways ER: endoplasmatic reticulum, TGN: transGolgi network, LE: late endosomes, EE: early endosomes, RE: recycling endosomes, SG: secretory granules, SV secretory vesicles 
Several pathways can be distinguished in membrane trafficking. Proteins, which should be secreted from the cell and membrane proteins of the plasma membrane, are going through the secretory pathway (fig.1). During their synthesis on ribosomes these proteins are translocated into the endoplasmatic reticulum (ER) and glycosylated there. Such proteins will be moved via the Golgi to the trans Golgi network (TGN), where they receive further glycosylation. Sorting of proteins occurs in the TGN: they can be packaged for regulated secretion into secretory granules (SG) or into constitutive secretory vesicles (SV). Lysosomal proteins are recognised in TGN and transported through late endosomes to lysosomes. Sorting signals for soluble lysosomal proteins are modifications with mannose6-phosphate, which is recognised in the TGN by mannose-6-phosphate receptors, mainly MPR-46 (Kornfeld and Mellman 1989). The complex of lysosomal protein and mannose6-phosphate receptor is transported to late endosome, where it dissociates. Mannose-6phosphate receptor then is transported back to the TGN via specific interactions with the transport machinery.

The functional role of lysosomes is degradation of extracellular and intracellular material. Lysosomal enzymes are transported from late endosomes to lysosomes. Some lysosomal proteins fail to be transported to late endosomes. In this case they go through the secretory pathway to the plasma membrane, then are recaptured by another kind of mannose-6phosphate receptor, MPR-300 and reach lysosomes via endocytosis. Sites for recognition and direction of membrane proteins to lysosomes are specific amino acid sequences in their cytoplasmic domains. Extracellular material reaches lysosomes through endocytosis via early endosomes (EE) and late endosomes (LE). Some of this material has to be returned back to the cell surface after being endocytosed. This takes place either directly from early endosomes or from recycling endosomes (RE). The best studied endocytic pathway involves clathrin, which forms coated membrane invaginations on the plasma membrane that recruit cell-surface receptors and then, through a series of highly regulated steps, pinch off to form clathrin-coated vesicles (Mukherjee et al. 1997; Kirchhausen 2000). Examples of receptor-mediated endocytic pathways are epidermal growth factor uptake mediated by its receptor EGF-R and asialoglycoprotein receptor (ASGR) mediated uptake of asialoglycoproteins. EGF-R is widely expressed by several cell types. The ASGR is galactose specific and plays an important role in endocytosis by hepatocytes. Clathrin 
coated pit formation is impossible without adaptorcomplexes (APs). Adaptor complexes are important for clathrin binding to a membrane to build clathrin-cages and for cargo selection (Ahle and Ungewickell 1989; Robinson 1994). Until now four different APs were described. AP-1 is predominantly associated with the Golgi-apparatus and mediates sorting and transport of MPRs from the TGN to endosomes (Le_Borgne and Hoflack 1998; Molloy et al. 1999). AP- 2 participates in internalisation of receptors from the cell surface (Schmid 1997). AP-3 is localised to the TGN and endosomes, its function is probably sorting of certain membrane proteins to lysosomes or related compartments like melanosomes. Mice lacking AP-3 complex subunits have pigmentation defects and storage pool deficiency (SPD). There are around 12 mouse mutants and several human diseases with similar phenotypes, which are probably all connected to that AP-3 dependent pathway. An example is the mouse pearl mutant, which is known to be a model for the rare case of Hermansky-Pudlak syndrome 2 (Huizing et al. 2000). AP-4 is associated with perinuclear compartments, possibly TGN. In experiments with MDCK cells AP-4 was shown to bind basolateral signals. This recent study connects its function to basolateral sorting in epithelial cells (Simmen et al. 2002). Less well characterised, but equally important, are non-clathrin endocytic pathways. These include phagocytosis, caveolaemediated uptake, macropinocytosis and constitutive non-clathrin uptake. Phagocytosis is usually restricted to macrophages and other phagocytes that specialise in uptake and digestion of large particles. Other distinct non-clathrin pathways mediate the uptake of smaller cargoes. They utilise either caveolae, macropinosomes or a little-understood constitutive process of plasma membrane internalization. A diverse array of molecular machinery is involved, including caveolin, ARF6, dynamin, ankyrin/spectrin, actin (Nichols and Lippincott_Schwartz 2001).

Autophagosomes are characterised by double membranes enclosing intracellular material. They fuse with lysosomes. Autophagy is a complex cellular process that involves dynamic membrane rearrangements under a range of physiological conditions for example amino acid starvation. It is a highly regulated process that plays a role in cellular maintenance and development, and has been implicated in a number of genetic diseases. Upon induction of autophagy, cytoplasm and organelles are sequestered into vesicles and delivered to a degradative organelle, the lysosome in mammalian cells. The process is unique in that it converts topologically intracellular material into topologically extracellular. A trait 
distingushing autophagosomes from endocytic organelles is the almost comlete lack of transmembrane proteins (Baba et al. 1995; Fengsrud et al. 2000). Autophagy is probably the main mechanism for degradation of long-lived proteins and the only mechanism for turnover of organelles including mitochondria and peroxisomes (Stromhaug and Klionsky 2001).

\subsection{Molecular mechanisms of membrane transport}

Membrane transport can be divided into different steps (see fig. 2) In the donor organell special proteins are responsible for sorting of cargo proteins into certain areas of the membrane. Coat proteins are recruited via small GTPases of the Arf or Sar-family. They allow construction of transport vesicles (Bednarek et al. 1996; Hirst and Robinson 1998).

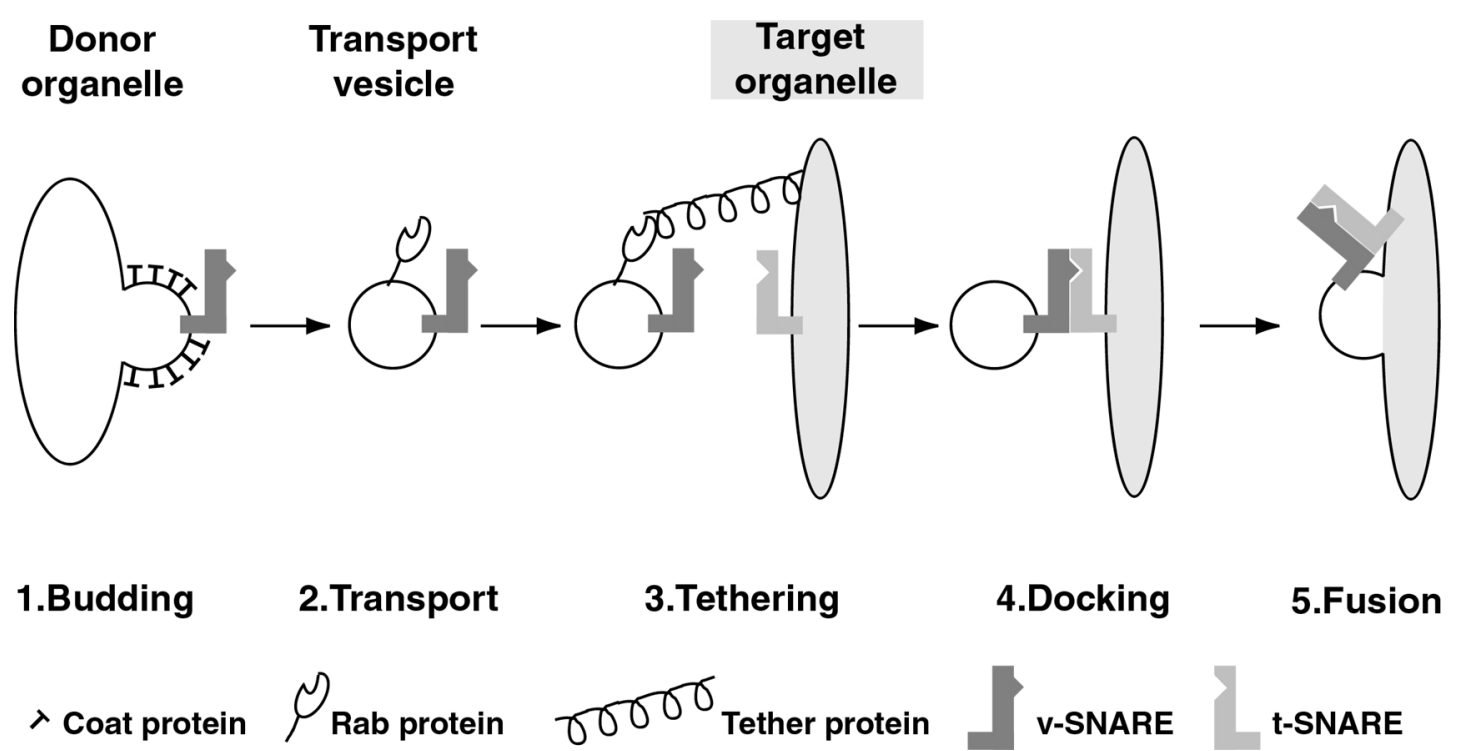

Figure 2: Schema of membrane transport through transport vesicles

Depending on the donor organelle different proteins are responsible for construction of transport vesicles. These vesicles will than be transported to the acceptor organelle through intractions of cytoskeleton and motor proteins (Govindan et al. 1995). Vesicles need to be recognised specifically by the acceptor organelle. This is mediated by an interaction of tethering proteins on a surface of an acceptor organelle with Rab proteins on the vesicle leading to a loose tethering. After membranes became attached, fusion is initiated in a step that involves SNAREs on both transport vesicle (v-SNARE) and target membrane (t-SNARE) which assemble into a SNARE complex. Merging of both the proximal and the distal leaflets of the fusing membranes opens the fusion pore and 
completes the fusion reaction. Finally, the fusion pore expands which is called fusion pore dilation (Jahn and Sudhof 1999). The specificity of membrane fusion is achieved by over 50 known rab-proteins and tethering proteins with specific membrane localisation (Martinez and Goud 1998). Tethering proteins form complexes with many subunits. Some of them can activate certain rab-proteins. It is thought that a signal arises due to the interaction of tether and $\mathrm{Rab}$ proteins which is then conducted to SNARE proteins $(\mathrm{SNARE}=\mathrm{SNAP}$ receptor, $\mathrm{SNAP}=$ soluble $\mathrm{NSF}$ attachment protein, $\mathrm{NSF}=\mathrm{N}-$ ethylmaleimide sensitive fusion protein). More then 40 known SNARE proteins have specific membrane localisation as well and thereby can contribute to specificity in membrane transport (Jahn and Sudhof 1999). NSF is an ATPase which dissociates SNARE complexes with the help of SNAP proteins after fusion allowing SNAREs to be transported to the donor organelle and to enter a new cycle of transport and fusion reaction (Grote et al. 2000).

\subsection{SNARE proteins}

Most SNARE proteins are attached to membranes through their C-terminal membrane anchor, a transmembrane domain or lipid modification. The SNARE superfamily is characterised by the presence of SNARE motif which is about 60 amino acid residues long (Jahn and Sudhof 1999). The SNARE motif is placed close to the membrane anchor and is responsible for SNARE-SNARE interactions and complex formations. SNARE proteins can contain one or two SNARE motifs. Criteria for the division of SNAREs into subfamilies are the sequences of the SNARE motifs. Up to now crystal structures of only two SNARE complexes have been solved. Well known now is the structure of the SNARE-complex, which takes part in fusion of synaptic vesicles with the plasma membrane. It is composed of the v-SNARE synaptobrevin 1 or synaptobrevin 2 , which is localised on synaptic vesicles and the plasma membrane t-SNARE proteins syntaxin 1 and SNAP-25 (Sutton et al. 1998). The crystal structure was obtained from recombinant SNARE motifs without transmembrane domains and corresponds probably to the stage after fusion (cis-SNARE-complex). The crystal structure showed a parallel bundle of four $\alpha$-helices formed by one helix of synaptobrevin 2, one of syntaxin 1 and two of SNAP-25 (fig.3a). 
A

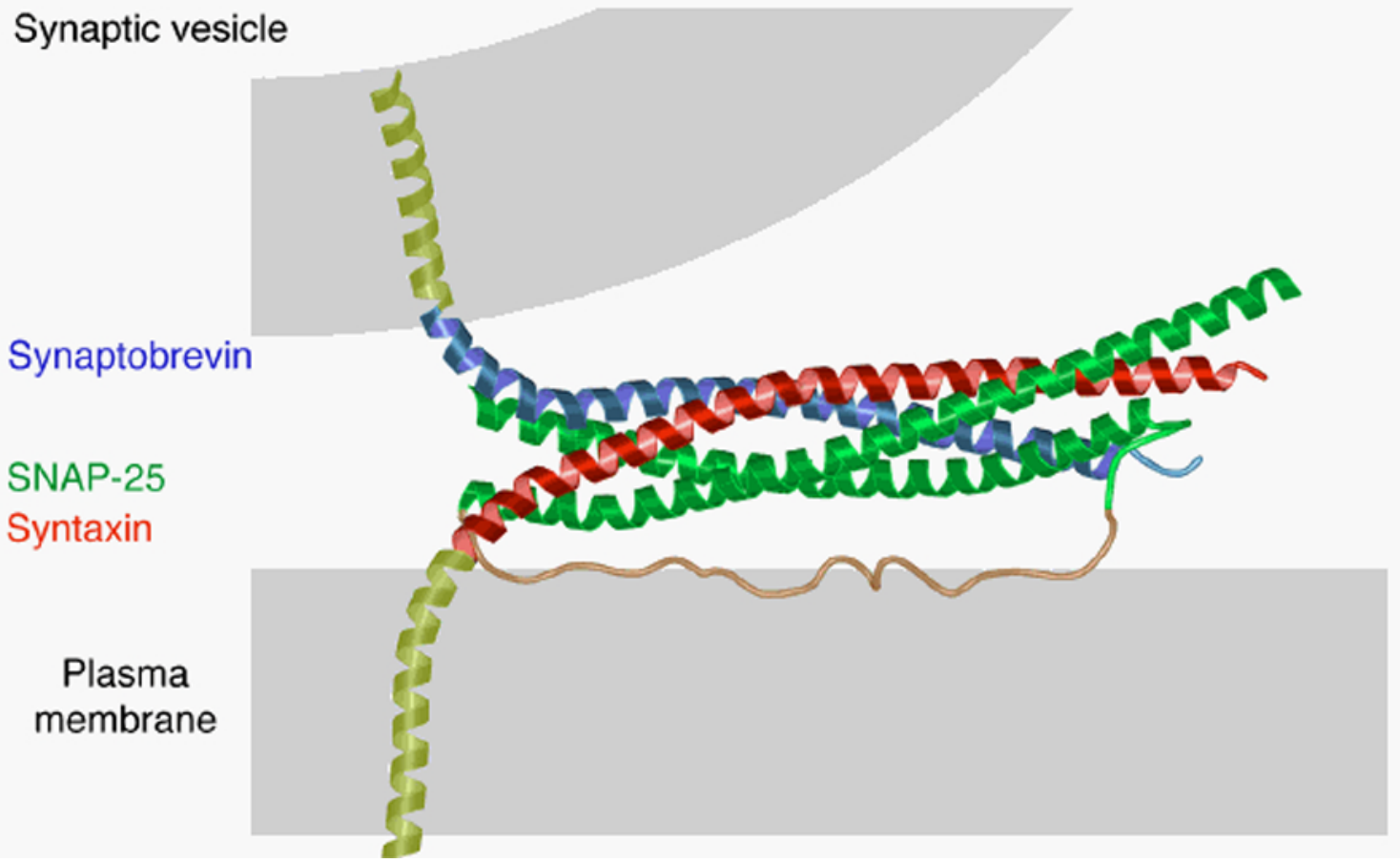

Sutton, Fasshauer, Jahn, Brunger (1998) Nature 395, 347-353

B

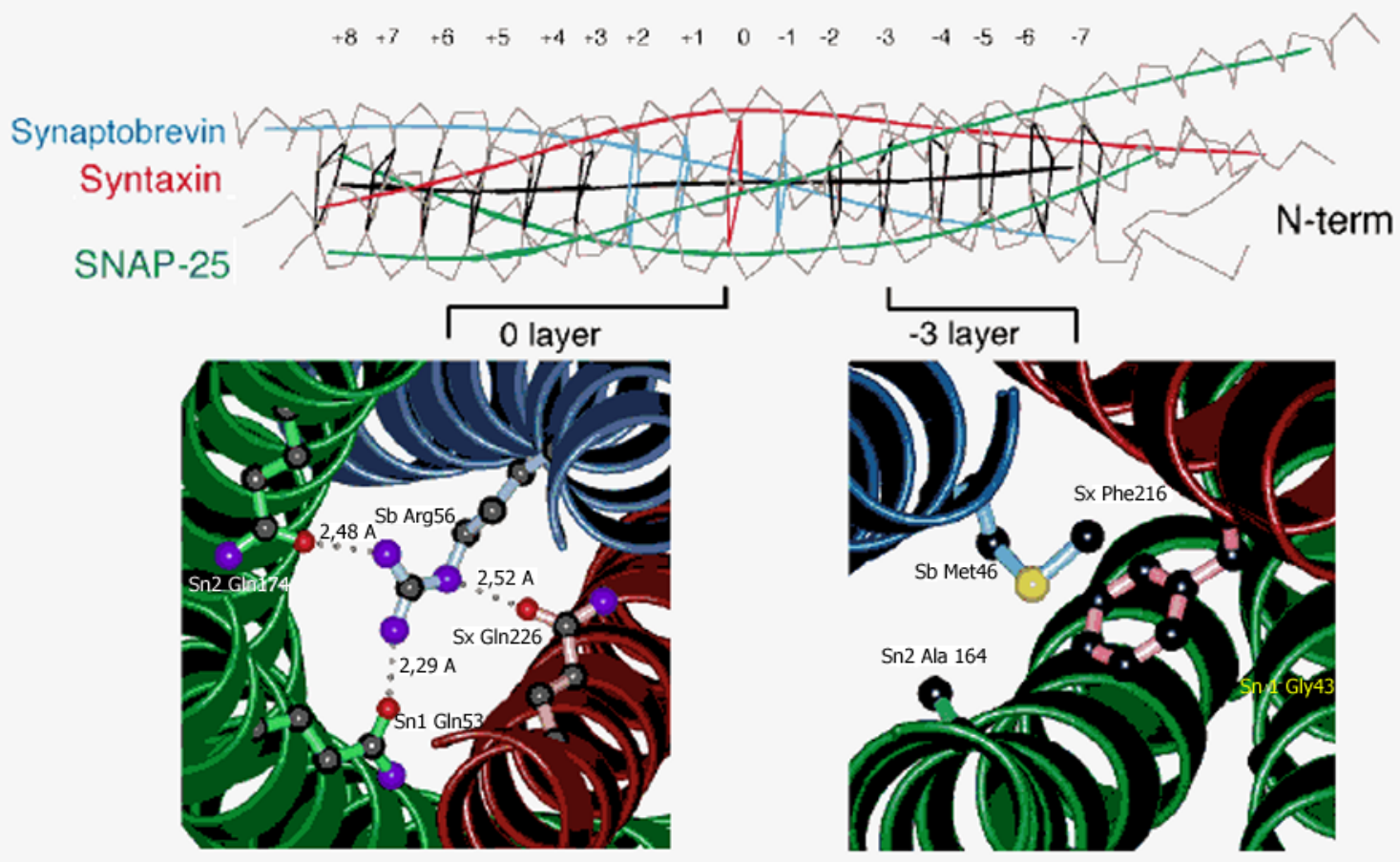

Sutton, Fasshauer, Jahn, Brunger (1998) Nature 395, 347-353

Figure 3: Modell of neuronal SNARE complex consisting of synaptobrevin, syntaxin, and SNAP-25 based on crystal structure 
In the SNARE complex 16 layers can be identified, in which amino acid residues from all four helices are oriented into the inside of the bundle and interact with each other (Fig.3b). In the layers most amino acid residues are hydrophobic, but one arginine $(\mathrm{R})$ residue of synaptobrevin interacts with three glutamine $(\mathrm{Q})$ residues of other helices in the middle of the bundle, in the so called 0 layer. The surface of the synaptic fusion complex is highly grooved and possesses distinct hydrophilic, hydrophobic and charged regions. These characteristics may be important for membrane fusion and for the binding of regulatory factors affecting neurotransmission (Sutton et al. 1998). Amino acid residues predicted to form all 16 layers of the bundle are highly conserved in different SNAREs. The highest degree of conservation is found in the ionic 0 layer. The (-3) layer is highly asymmetric, composed of two big and two small amino acid residues, which are methionine in the RSNARE synaptobrevin and phenylalanine in syntaxin 1, and glycine and alanine in SNAP25. The -3 layer of other SNARE complexes is also composed of two big and two small amino acid residues. Both big amino acid residues are contributed by syntaxin 1- and synaptobrevin- related SNAREs, the small ones come from SNAP-25 homologues, to which a subgroup of syntaxins and Vtil proteins belong. Mutations in these layers reduce complex stability and cause defects in membrane traffic even in distantly related SNAREs. When syntaxin 4 is modelled into the synaptic fusion complex as a replacement of syntaxin 1 , no major steric clashes arise and the most variable amino acids localize to the outer surface of the complex. Therefore the main structural features of the neuronal complex are highly conserved during evolution (Fasshauer et al. 1998b). Very recently a crystal structure of the late endosomal fusion complex has been solved at a resolution of $1,9 \AA$. Despite limited sequence homology, the helix alignment and the layer structure of the endosomal SNARE complex are remarkably similar to those of the neuronal complex (Antonin et al. 2002). More evidence supporting the four-helix bundle model is derived from other well characterised SNARE complex. Membrin, r-bet1, syntaxin5 and msec22b form a SNARE complex that operates in ER to Golgi transport in mammals and is equivalent to the yeast complex consisting of Bos 1p, Bet1p, Sed5p and Sec22p (Xu et al. 2000). In contrast with the four-helix-bundle model of SNARE complexes, there are data supporting existence of pentameric SNARE complex (Ungermann et al. 1999). Five SNAREs Vam3p, Vam7p, Nyv1p, Vtilp and Ykt6p are required for vacuolar homotypic fusion and were coimmunoprecipitated. However, another group demonstrated that the five 
vacuolar SNAREs can assemble into either of two alternative quaternary complexes, in which Nyv1p and Ykt6p competed for the same position. A pentameric complex was never detected (Fukuda et al. 2000).

\subsection{Classification of SNARE proteins}

In mammalians more then 40 SNAREs were identified within the last years. Well known is the classification of SNAREs into $\mathrm{v}$ - and $\mathrm{t}$ - SNAREs, where $\mathrm{v}$ - stands for vesicular and $\mathrm{t}$ for target membrane SNAREs. The division of SNAREs into only two groups according to localisation is problematic and does not allow to assign a functional role to each SNARE and to predict SNARE complexes. On one hand, there is no distinction between the membranes in homotypic fusion. On the other hand SNAREs are constantly transported with membranes and a single SNARE can be found in several membrane compartments. So localisation itself cannot determine in which transport step a certain SNARE protein functions and whether it is a v- or t- SNARE. There are sequence homologies between SNAREs supporting a new classification (Weimbs et al. 1998). The crystal structure of the neuronal complex gave a functional relevance for this novel classification of SNAREs. These proteins were divided into R- and Q- SNAREs on the basis of having an arginine or glutamine residue in the position predicted to form the 0 layer of the complex (Fasshauer et al. 1998a). In this case all t-SNAREs are Q-SNAREs, however v-SNAREs can be R- or QSNAREs. The conserved asymmetric -3 layer allows for further division of Q-SNAREs into syntaxin-related and SNAP-25 related Q-SNAREs: syntaxin 1 has here a big amino acid residue, phenylalanine, both SNAP-25 helices a small amino acid residues (glycine and alanine). Furthermore, a distinction can be made between SNAREs, more related to the N-terminal helix of SNAP-25 (SNAP-25N) and to the C-terminal helix of SNAP-25 (SNAP-25C). 


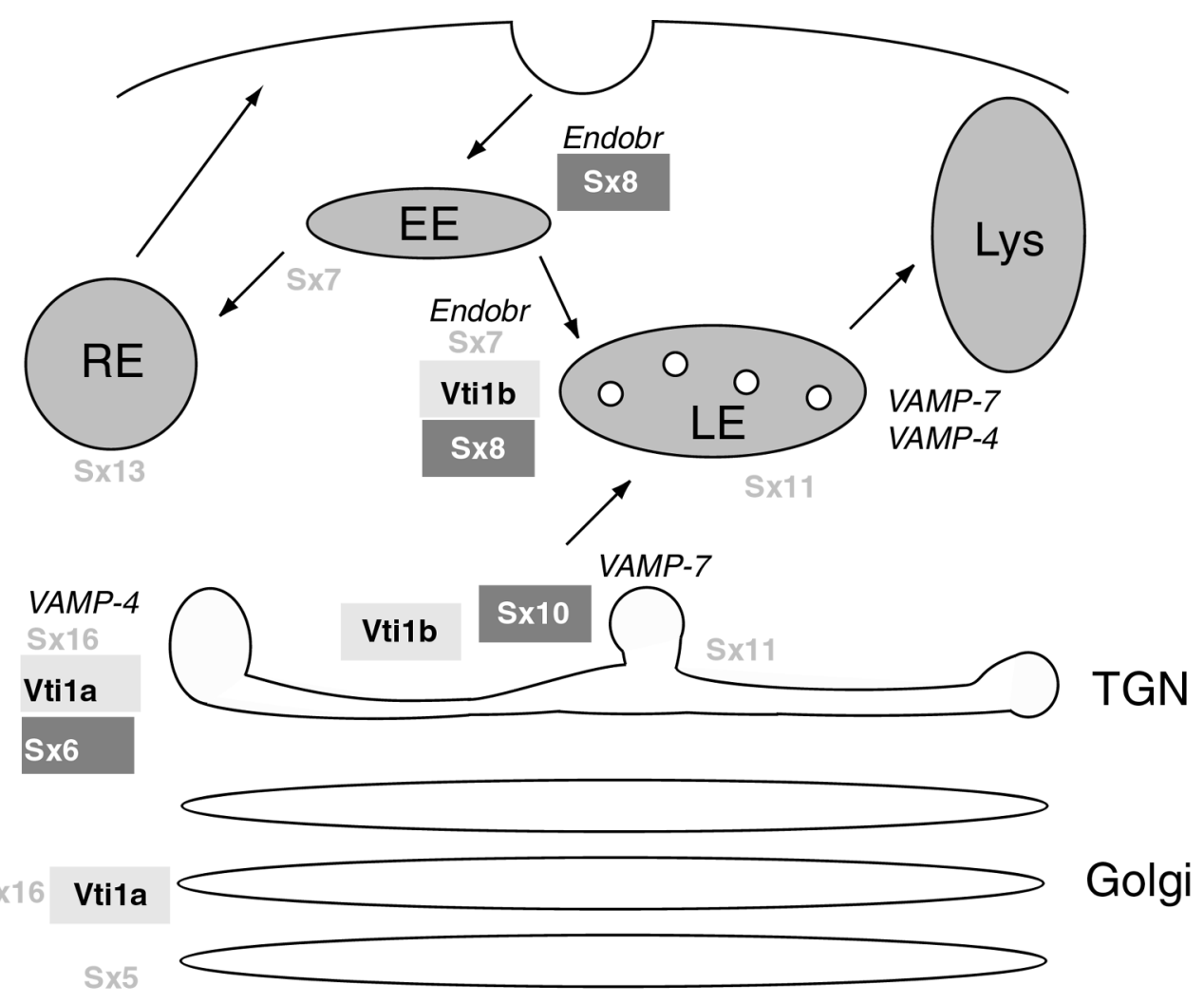

\section{R-SNARE Syntaxin, Qa SNAP-25 N, Qb SNAP-25 C, Qc}

\section{Figure 4: SNAREs of TGN and endosomal membrane system of mammals}

This classification is consistent with a division of SNAREs into Qa, Qb, Qc -SNAREs and R-SNAREs (Bock et al. 2001). That classification was done using a genomic approach, where similarities and differences in primary amino acid sequences were examined within the SNARE superfamily. Syntaxin 7 and 16 for example were placed into the Qa group (syntaxins), Vtil proteins into the Qb group (homologs of the N-terminal helix of SNAP25 ) and syntaxin 6 and 8 into the Qc group (SNAP-25 C terminal helix homologs). VAMPs $(4,5,7$ and 8$)$ are R-SNAREs. This reclassification is of great functional importance because it is predicted that each SNARE complex contains one helix of each of the four subgroups.

\subsection{Subcellular distribution of SNAREs}

SNARE proteins can be found on all intracellular compartments. Figure 4 shows the localisation of several SNAREs important for this work. As mentioned earlier, SNAREs are constantly moved from donor to acceptor compartment on the surface of transport 
vesicles. After membrane fusion a SNARE protein should be recycled back to the donor compartment. Therefore localisation of a SNARE is not sufficient to predict its function (Jahn and Sudhof 1999). Endobrevin (VAMP 8) is localised to early and late endosomes (Antonin et al. 2000b). Syntaxin 8 is preferentially associated with early endosomes, indicated by its co-labelling with Rab5 according to one study (Subramaniam et al. 2000) and with the TGN in another one (Prekeris et al. 1999). Functional studies and electronic microscopy data show syntaxin 7 localisation to late endosomes (Mullock et al. 2000) and to the early endosomes (Prekeris et al. 1999). Electron microscopy and fluorescent confocal microscopy allowed the localisation of Vtilb to endosomal structures and the TGN (Kreykenbohm et al. 2002). These data are all coherent with in vitro studies of late endosomal fusion and solving of the crystal structure of the endosomal SNARE complex (endobrevin /syntaxin 7/syntaxin 8/ Vti1b) (Antonin et al. 2002). Vtila is found predominantly in the Golgi and TGN and has therefore a localisation distinct from that of Vtilb (Kreykenbohm et al. 2002). A brain-specific splice variant of Vti1a, Vti1-ß is localised to small synaptic vesicles (Antonin et al. 2000c). Mechanisms of sorting of SNARE proteins to certain compartments are still unknown. It is likely that adaptor complexes play a role. It is intriguing that VAMP-7 contains a potential adaptor protein binding motif, D/EXXXLL (aa 162-167), within the SNARE coil domain. Perhaps each of the SNAREs contains specific sequences that direct binding to particular adaptor proteins. The small number of amino acid residues that are so far defined to be important for adaptor binding interactions makes it difficult to understand their significance simply by inspection of amino acid sequences of the SNAREs (Advani et al. 1999). Only VAMP-4 and VAMP7 contain recognizable di-leucine motifs, suggesting that alternative or additional motifs may regulate adaptor binding to SNARE or cargo molecules. Some experiments to clarify these issues were done recently. AP-1 specifically binds to VAMP-4, and this binding is dependent on the di-leucine motif of VAMP-4. Transfection of cells with VAMP-4 constructs lacking the di-leucine motif results in VAMP-4 mislocalisation. This shows that AP-1 and VAMP-4 interaction is required for proper sorting of VAMP-4 suggesting that other SNAREs may interact with adaptor complexes (Peden et al. 2001). 


\subsection{Function of SNAREs}

A link between SNAREs and exocytosis was established by the discovery that botulinum and tetanus toxins - a group of eight related paralytic neurotoxins producted by Clostridia - block neuronal exocytosis by selectively proteolysing individual SNARE proteins (Niemann et al. 1994; Montecucco and Schiavo 1995). Although the core complex itself is resistant to proteolysis, single SNAREs remain available to toxins and that prevents formation of new complexes and blocks membrane fusion in this way. Mutations in yeast SNAREs and in vitro transport assays confirmed that SNARE complexes are essential for fusion but not for membrane tethering (Mayer and Wickner 1997; Cao et al. 1998). Mutations affecting the core complex resulted in more or less severe loss-of-function phenotypes, supporting the key role of SNARE assembly in fusion (Jahn and Sudhof 1999). Nowadays, several steps in membrane fusion are distinguished: priming, tethering, docking, hemifusion (stalk formation), fusion pore formation, and fusion pore dilation. The "zipper" model of SNARE function in membrane fusion hypothesizes that SNARE proteins "zip" from their membrane distant amino terminal ends toward the membraneproximal carboxy termini. SNARE complex assembly may drive the establishment of a hemifusion stalk (Jahn and Sudhof 1999). Once the amino termini have found each other, they may partially zip together, probably establishing a stalk-like membrane merger that reflects the fusion of proximal, but continuity of distal, leaflets resulting in hemifusion state (Zimmerberg and Chernomordik 1999; Lentz et al. 2000; Bruns and Jahn 2002). In viral fusion events hemifusion is viewed as a bona fide state that can progress to full merger of membranes (Razinkov et al. 1999; Melikyan et al. 2000). Since a lot of SNAREs are already known and their localisation is specific, there are assumptions about their role in specificity of membrane transport. This complex problem now is a subject of discussion for several research groups. Liposome-based in-vitro fusion assay support the hypothesis that only cognate SNAREs can form a complex and that indeed plays a role in specificity of membrane trafficking (Fukuda et al. 2000; McNew et al. 2000; Parlati et al. 2000). The idea is that for example, the SNAREs on the ER-derived vesicle can form a complex only with those on the Golgi, ensuring specificity. Such SNAREs are said to be "cognate". Cognate SNAREs belong to four families: A designates Q-SNARE syntaxin, B and C the Q-SNAREs of the SNAP-25 family, and D the R-SNARE of the VAMP family (Sutton et al. 1998; Yang et al. 1999). However in vitro SNARE complex assembly from purified 
proteins showed that these four different types of helices are needed for complex formation but it did not matter from which SNARE protein these coils originated (Fasshauer et al. 1999; Yang et al. 1999). In contrast, another study showed that in cracked PC12 cells only cognate SNAREs when added in solution could compete with membrane-bound SNAREs. They inhibit vesicle fusion - with a couple of exceptions, non-cognate SNAREs in solution could not. It was then supposed that the information for SNARE pairing specificity is not completely determined by the ability to form stable complexes, but is probably determined through interactions with other proteins. Additional proteins may be required for formation of the core fusion complex in vitro and Rabs, rab effector proteins and sec1 family members are potential candidates for that (Scales et al. 2000). There are examples in which non-cognate $\mathrm{A}, \mathrm{B}, \mathrm{C}$ and D SNARE motifs result in fusion in vitro. With the plasma membrane $\mathrm{A}, \mathrm{B}$, and $\mathrm{C}$ helices, fusion can occur when any $\mathrm{D}$ helix with a transmembrane domain is used (McNew et al. 2000). So isolated SNAREs cannot solely account for the specificity observed in vesicle trafficking (Scales et al. 2000). Studies in yeast showed that the SNARE proteins Vtilp and Ykt6p can participate in three different transport steps. Functional data indicate that the R-SNARE Ykt6p together with the Q-SNARE Vtilp form three different SNARE complexes with the syntaxin-related Q-SNAREs Sed5p, Pep12p and Vam3p localised to the Golgi apparatus, the prevacuole and the vacuole respectively. Authors conclude that Ykt6p or Ykt6p and Vtilp on the transport vesicle are not sufficient to ensure specificity in membrane traffic (Dilcher et al. 2001). This would support participation of additional proteins in vesicular targeting (Fischer von Mollard et al. 1997; Lazar et al. 1997; Lupashin et al. 1997; Dilcher et al. 2001). It seems that the accuracy of vesicle targeting is safeguarded not through a single lock-and-key interaction between SNAREs, but rather through several layers of constraints - a situation common to many biological processes (Scales et al. 2000). The most fundamental question remains, namely whether SNARE proteins indeed operate in "zipper" mechanism as fusogenic motors or simply serve as workhorses to pull membranes together thus transferring them into a readily releasable state. Completion of fusion is then performed by an unknown downstream protein (Bruns and Jahn 2002). A very different point of view on the role of SNARE complex formation is suggested by Ungermann et al., 1998. Whereas in the "zipper" model of membrane fusion SNARE complex assembly is considered as driving force, these authors consider the transition from cis-SNARE complex to trans-SNARE 
complex as only a transient state, which preceeds fusion, and as a signal to downstream factors, which are the fusion machinery. In in vitro experiments on homotypic yeast vacuolar fusion it was shown that trans-SNARE complexes can be dissociated by excess Sec17(SNAP-homolog) and Sec18 (NSF-like ATPase). That had only a small effect on overall fusion, indicating that other factors may be required for the fusion reaction (Ungermann et al. 1998).

In the second class of hypotheses, the gap between the fusing membranes is bridged by a hypothetical protein complex whose opposite ends enter and/or span both bilayers. That model which is quite an old has an experimental backing. Several assumptions come from experiments on vacuolar fusion (Peters and Mayer 1998; Peters et al. 1999; Peters et al. 2001). A central point of this alternative mechanism of membrane fusion is the V-ATPase. The V-ATPase is a proton pump that acidifies various compartments. It can undergo regulated disassembly, shedding its periferal V1 sector into the cytosol and silencing its ATPase activity (Kane and Parra 2000). The membrane integral V0 sector consists of several subunits and includes a multimeric (probably hexameric) cylinder of proteolipids small tetraspanning membrane proteins. Purified reconstituted proteolipids can form $\mathrm{Ca}^{2+}$ inducible pores, which can expand to mediate passage of even large ions such as acetylcholine (Dunant and Israel 1998). After vacuoles have docked and trans-SNARE complexes have formed, but before fusion has occured, VO sectors from apposed membranes form trans-complexes (Peters et al. 2001). These trans complexes do not contain V1 sectors and are strongly enriched in calmodulin and the vacuolar Q-SNARE Vam3. It appears that interaction with the Q-SNARE Vam3 and calmodulin might recruit a subset of V0 sectors for the formation of trans complexes during fusion (Mayer 2001). Supportive for this hypothesis is that V0 is present on all compartments of the secretory and endocytic pathways, including the plasma membrane (Harvey and Wieczorek 1997). $\mathrm{Ca}^{2+}$ and calmodulin, which binds $\mathrm{V} 0$, is also required for intra-Golgi transport and endosome fusion (Colombo et al. 1997; Porat and Elazar 2000). Endosome-lysosome fusion is $\mathrm{Ca}^{2+}$ dependent (Pryor et al. 2000). Two apposed V0 sectors might establish a continuous proteinaceous channel with a central pore between the two membranes. Radial opening of this pore could initiate fusion, whereas lateral separation of the subunits could create amphiphilic clefts that could be invaded by lipids and thereby initiating fusion pore formation. However, strong functional evidence for involvement of V0 sectors in the late 
reaction stage remains to be established (Mayer 2001). Up to now it is not clear if one or another model of membrane fusion is true. It is possible that elements of the contradictory models are present in the real situation. Trans SNARE complex might initiate merging of the membrane leaflets and lipid transfer and only the completion of fusion pore formation or its expansion might be independent of trans-SNARE complexes. On this stage a poremediated fusion could act (Mayer 2001). It is also possible that there is no universal mechanism of membrane fusion and some reactions like exocytosis are mediated by transSNARE complexes machinery whereas vacuole fusion involves other mechanisms. There is novel evidence that vacuolar fusion is more complicated than vesicle exocytosis and may therefore require proteins after the action of SNAREs. Proteins involved in docking and fusion accumulate as a vertex ring in large contact zones between vacuoles. Membrane fusion is then coordinated around the vertex ring and needs vacuolar transporter chaperone complex (VTC) and Vac8p protein. Several fusion pores connect and leave an internal membrane which is located inside of fused vacuoles (Wickner 2002).

\section{$1.7 \quad$ Vti1 proteins}

\subsubsection{Yeast Vti1p}

Yeast Vtilp has been discovered in a 2-hybrid screen as a binding partner of the cytoplasmic domain of the CPY-receptor Vps10p but the relevance of this interaction is unclear. Vti1p has 217 amino acids, a C-terminal transmembrane domain and a luminal tail of four amino acids. The SNARE motif with a glutamine in the 0 layer is placed next to the transmembrane domain. Accordingly to its sequence homology Vtilp belongs to QSNAREs related to the N-terminal helix of SNAP-25. Vtilp is localised to the Golgi apparatus and endosomes using immunofluorescence microscopy and subcellular fractionation. VTI1 is an essential gene; its deletion is lethal (Fischer von Mollard et al. 1997; Fischer von Mollard and Stevens 1999). Functional studies revealed the importance of Vtilp in several transport steps in yeast cells: from the Golgi to late endosomes, retrograde transport to the cis-Golgi; biosynthetic transport to the vacuole, the equivalent of mammalian lysosome; homotypic vacuolar fusion (fig.5) and TGN homotypic fusion. Thus Vtilp is a part of four distinct SNARE complexes. 


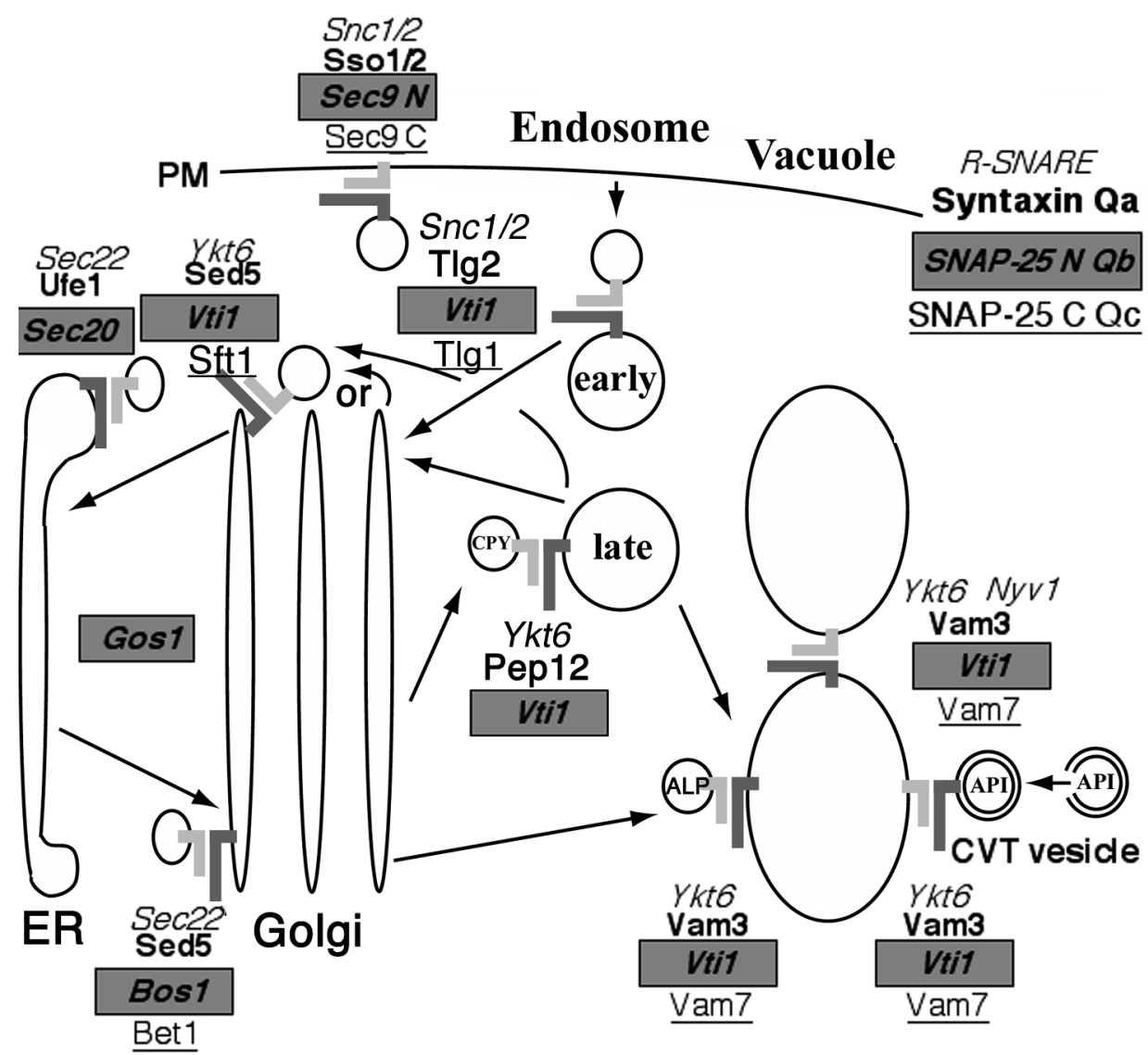

Figure 5: Transport pathways and SNARE complexes in yeast cells

\subsubsection{Vti1 homologs}

Database searches show homologs of Vtilp in model organisms such as Arabidopsis, C.elegans, and Drosophila. Mammals have two homologs of Vti1p, Vtila (27kDa) and Vtilb (29kDa). Vtilp has 33\% amino acid identity with Vtila and 27\% with Vtilb. Mouse Vtila and Vtilb share only $30 \%$ amino acid identity, indicating that they are very divergent proteins. In brain a splice form of Vtila, Vti1a- $ß$ was found (Antonin et al. 2000c). In contrast to other Q-SNAREs and all other Vtil proteins mouse and rat Vtila have an aspartate in place of the highly conserved glutamine. An aspartate residue should be able to make strong ionic interaction with an arginine residue of the ionic 0-layer (Antonin et al. 2000c). Are Vtila and Vtilb redundant proteins or did they evolve into more specialised proteins than their yeast homolog? In the second case Vtila and Vtilb should have distinct localisation, SNARE partners and function. 


\subsubsection{Mammalian Vti1b}

Vti1b has 233 amino acid residues. Preliminary studies on Vti1-rp1 (Vti1b) suggested that it is preferentially associated with the TGN and/or endosomal compartment (Xu et al. 1998) or with the Golgi and TGN (Advani et al. 1998). A recent study showed Vti1b localization to the perinuclear area with extention of the staining further into the perifery of the cell. Little overlap was observed with the Golgi marker protein giantin. Also localization of Vtilb was unchanged after brefeldin A treatment. Vtilb was localized to early endosomes, multivesicular late endosomes, and tubules and vesicles not connected with the TGN by immuno electron microscopy. The study clearly shows distinct localisations of Vtilb and Vtila (Kreykenbohm et al. 2002). hVtilb could functionally substitute for yeast v-SNARE Vtilp in two vesicle transport pathways in retrograde traffic to the cis-Golgi and in traffic from the Golgi via the late endosome to the vacuole (Fischer von Mollard and Stevens 1998). Vti1b is a member of a SNARE complex mediating fusion of late endosomes in vitro. In addition to Vtilb, the complex consists of syntaxin 7 , syntaxin 8, and endobrevin/VAMP-8. Antibodies against each member of the complex inhibit late endosomal fusion in vitro and retard delivery of epidermal growth factor to lysosomes in vivo. By contrast, fusion of early endosomes was not inhibited by antibodies directed against Vtilb (Antonin et al. 2000a). Syntaxin 7 interacted with Vtilb and endobrevin in B16 melanoma cells (Wade et al. 2001). A coimmunoprecipitation of syntaxin 8 with Vtilb was also described by Subramaniam et al.(Subramaniam et al. 2000). A complex with the SNARE motifs of Vtilb, syntaxin 7, syntaxin 8 and endobrevin/VAMP-8 was recently crystallised and it was found that the structure is a four helix-bundle, very similar to the neuronal SNARE complex (Antonin et al. 2002). Vtilb takes the position of the N-terminal helix of SNAP-25, whereas syntaxin 8 is equivalent to the C-terminal helix of SNAP-25.

\subsubsection{Mammalian Vti1a}

The existence of a second mammalian Vtilp homologue first was discovered through database searches. The deduced amino acid sequence of Vti1-rp2 (Vtila) has 217 residues with a $\mathrm{COOH}$-terminal membrane anchor. Affinity purified antibodies raised against the cytoplasmic region of this protein specifically detect a 29-kilodalton integral membrane protein enriched in the Golgi membrane (Xu et al. 1998). By immunofluorescence and 
immuno-electronmicroscopy Vtila was localised to the Golgi and the TGN.

(Kreykenbohm et al. 2002). Vtila was coimmunoprecipitated with syntaxin 5 and syntaxin 6 , but syntaxin 5 and syntaxin 6 were not part of the same complex, showing that Vtila might be a member of two distinct SNARE complexes (Xu et al. 1998). Vtila was coimmunoprecipitated with VAMP-4, syntaxin 6 and syntaxin 16 (Kreykenbohm et al. 2002). Vtila, syntaxin 6, syntaxin 16 in a t-SNARE complex interacted with VAMP-4 or VAMP-3 in two different quaternary SNARE complexes (Mallard et al. 2002). Using a novel permeabilised cell system, it was shown that these complexes have a role in transport from early endosomes/recycling endosomes to the TGN. Antibodies directed against Vtila inhibited fusion of early endosomes in vitro (Antonin et al. 2000a) as well as transport of VSV-G glycoprotein through the Golgi (Xu et al. 1998). Vtila has a brain-specific splice form Vti1a- $\beta$, which is localised to small synaptic vesicles. Vtila- $\beta$ was enriched on small synaptic vesicles using subcellular fractionation. Vtila- $\beta$ has seven additional amino acids (LIKLREE) directly N-terminal before the SNARE motif has in that can possibly play an important role for cellular distribution of that protein (Antonin et al. 2000c). Ultrathin cryosections obtained from mossy fiber synapses were stained with antibodies which recognise both Vti1a and VTila- $ß$. Nerve terminals were mainly decorated with antibodies against Vtila and protein A gold. Small synaptic vesicles stained with Vtila antibodies are visible in presynaptic nerve terminals at higher resolution.VAMP-4, syntaxin 6 and syntaxin 16 coenriched with purified small synaptic vesicles. These data support the view that these four SNAREs form a complex that might be functional in the life cycle of synaptic vesicles (Kreykenbohm et al. 2002).

\subsection{Targeted gene replacement as tool for studies of mammalian protein function}

Mutants are the most important tools for assigning biological functions to genes. Targeted mutation can be generated in a selected cellular gene by inserting mutant copies of the gene into cells and screening for cells in which the mutant copy has taken place of the original, healthy gene on a chromosome by homologous recombination. Such altered cells are helping researchers to produce mice carrying specific genetic mutations. The currently available technologies for in vitro manipulation of mouse embryonic stem cells have opened up new areas in mammalian genetics. Mutations can be generated at will in defined 
genes thought to be involved in any biological process, including those involved in human genetic diseases. A lot of examples can be named, where genetic "knock-out" in mice generated a model of severe human disease. Gene targeting technologies allow asking questions as to the in vivo functions of a specific gene in the context of the whole animal or its different cell types. 


\section{$2 \quad$ Aim of the work}

An aim of this work was to isolate mouse genomic DNA for Vtilb and Vtila, to characterise the chromosomal regions encodingVtilb and Vtila for targeted gene replacement and generation of null mutant mice to describe a role of mammalian Vti1b, a homolog of yeast Vtilp. Knockout mice have several important advantages compared to studies in vitro. The development of the organism can be analysed, defects in specific organs and cell types can be investigated. In case of success in Vtilb knock-out mice generation, special aims of this work were:

to describe phenotypic manifestation of Vtilb deficiency, to study the role of Vtilb in membrane traffic, to prove the proposed role of Vtilb in late endosomal fusion in vivo using endosomal tracer assays, to study properties of Vtilb deficient cells and tissues using biochemical and cell biological methods, to use Vtilb deficient cells as a tool for the identification of additional components of the fusion machinery.

A second general aim of this study was the deletion of mVtila in mice. Vtila deficiency in the whole organism can show the role of this protein in membrane traffic and define the function of its splice variant Vtila- $\beta$ in small synaptic vesicle biogenesis or recycling. 


\section{$3 \quad$ Materials and methods}

\subsection{Materials}

\subsubsection{Devices}

Analytical balances type 1602 MP and M5P

Autoclave type Technoclav 50

Balances type $1264 \mathrm{MP}$ and 1265

Chamber for agarose gel electrophoresis

Chamber for polyacrylamide gel electrophoresis

Centrifuges:

Biofuge Fresco

Cooling centrifuge, model J-21 C and J2-MC

Eppendorf centrifuges 5414 and 5415C

Megafuge 1.0

Rotors for cooling centrifuge:

JA-10 rotor, till $17680 \times \mathrm{g}$

JA-20 rotor, till $48300 \mathrm{x} g$

Laborfuge GL

Ultracentrifuge TL-100

Rotor for TL-100: TLA-100.3, till $430000 \mathrm{x} \mathrm{g}$

Electroporator 1000 Stratagene ${ }^{\circledR}$

Film developer Curix 60, automatic

Flake ice machine

Fluorescent spectrophotometer F1200

Freezer, $-80 \mathrm{C}^{\circ}$

Gel air dryer BioRad

Gene Pulser ${ }^{\mathrm{TM}}$ and Capacitance extender (125-960

$\mu \mathrm{F}$ )

Incubator type 2771

Incubator, water surrounded, stable $\mathrm{CO}_{2}$

atmosphere

Laboratory "rugged" rotator

Liquid nitrogen storage tank Biosafe Chronos

Liquid scintillation counter model 1900TR

Luminescent image analyser LAS - $1000 \mathrm{CH}$

Microscopes:

Axiovert 100 / CCD camera TILL Photonics

Laser Scanning Microscope LSM 310

ID 03 light microscope

Microwave oven
Sartorius, Göttingen

Tecnomara, Zürich, Switzerland

Sartorius, Göttingen

Self-made, workshop of the institute

Self-made, workshop of the institute

Schütt, Göttingen

Beckmann, München

Schütt, Göttingen

Heraeus, Göttingen

Beckmann, München

Heraeus, Osterode

Beckmann, München

Beckmann, München

Cortland NY, USA

AGFA-Gevaert, Leverkusen

Ziegra, Isernhagen

HITACHI, Tokyo, Japan

Colora Messtechnik, Lorch

Hercules, CA, USA

BioRad, München

Heraeus, Osterode;Köttermann, Häningsen

Forma Scientific, Marietta, USA

Self-made, workshop of the institute

Messer Griesheim, Frankfurt/M.

Packard, Frankfurt/M.

Fuji Film,

Zeiss, Oberkochen/Gräfelfing

Zeiss, Oberkochen

Zeiss, Oberkochen

Bosch, Stuttgart 
Mortar and pestle

Multichannel Finnpipette ${ }^{\circledR} 50-300 \mu 1$

Peristaltic pump P1

pH-meter CG 820

Phosphoimager, IPR1000

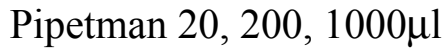

Power supply Gibco BRL Electrophoresis

Platform rocker

Semi-dry-blot-system

Shaker incubator G 25

Shaker waterbath GFL 1083

Spectrophotometer Uvikon 810

Standard power pack P25 Biometra ${ }^{\circledR}$ Bio105 LVD

Steri-kult-incubator, 3035/200

Sterile hood, A/B3 \& SG 400

Surgical scissors; small, formed

Surgical scissors; small, straight

Thermocycler Master cycler gradient

Thermocycler Gene Amp 9600

Thermo mixer compact Eppendorf

Thermo printer

Thermostat 5320

Transilluminator Modell IL-400-M

Tweezers

Ultrasound-disintegrator Sonifier W-450

Ultra-Turrax T25

Ultra low freezer $-80^{\circ} \mathrm{C}$

UV-hand lamp( $312 \mathrm{~nm}$ and $254 \mathrm{~nm}$ )

Video camera

Video printer

Vortex-Genie

Waterbath type HOR 7225
Schütt, Göttingen

Labsystems, Helsinki, Finland

Pharmacia, Uppsala, Sweden

Schott, Göttingen

Fuji, Tokyo, Japan

Gilson Medical Electronics,

Villers-le-bel, France

Gaitherburg, MD, USA

Self-made, workshop of the

institute

CTI GmbH, Idstein

News Brunswick Sc., Edison/USA

Köttermann, Häningsen

Kontron, Eching

Biomed Analytic, Göttingen

Forma Scientific, Marietta, USA

Baker Company,Inc., Stanford,

USA

Aesculap, Tuttlingen

Aesculap, Tuttlingen

Eppendorf, Hamburg

Perkin-Elmer Cetus, Norwalk,

USA

Kottberg, Göttingen

Intas, Göttingen

Eppendorf, Hamburg

Bachofer, Reutlingen

Aesculap, Tuttlingen

Branson Ultrasonic SA, Carouge-

Geneve, USA

Janke\&Kunkel, Staufen

New Brunswick Scientific, USA

Bachofer, Reutlingen

Intas, Göttingen

Intas, Göttingen

Bender\&Hobein AG, Zürich,

Switzerland

Köttermann, Häningsen

\subsubsection{Materials}

Catheter (for blood vessels) Jelco ${ }^{\mathrm{TM}}$

Criticon, Norderstedt

Cell culture flasks 25 and $75 \mathrm{~cm}^{2}$

Greiner, Nürtingen

Cell culture pipettes for single use, $2 \mathrm{ml}, 5 \mathrm{ml}, 10$

Greiner, Nürtingen

$\mathrm{ml}, 25 \mathrm{ml}$

Cell culture plates $35,60,100$ and150 mm $\varnothing$

Greiner, Nürtingen

Cellophane foil

Pütz-Folien, Taunusstein-Wehen 
Centrifuge glass:

JA-10 polypropylene

JA-20 polypropylene

Corex ${ }^{\circledR}$ II centrifuge tubes $15 \mathrm{ml}$

Cryotubes $1,8 \mathrm{ml}$

Disposable hypodermic needles for single use,

Braun

Glass beakers $25 \mathrm{ml}, 50 \mathrm{ml}, 100 \mathrm{ml}, 250 \mathrm{ml}, 1000$

$\mathrm{ml}$

Glass fibres Assistent ${ }^{\circledR}$

Hybond-N ${ }^{\mathrm{TM}}$ filters

Hypodermic syringe for single use

Nitrocellulose blotting membranes $0,2 \mu \mathrm{m}$

Parafilm ${ }^{\circledR}$

Pasteur pipettes

Pipette tips $10 \mu 1,200 \mu 1,1000 \mu 1$

Pipette tips filtered, sterile $10 \mu 1,200 \mu 1 / 1000 \mu 1$

$\mathrm{M}_{\beta} \mathrm{P}^{\mathrm{TM}}$

Pipette tips Finntip 300 $\mu 1$

Polycarbonate centrifuge tubes for rotor TLA100.3

Polyvials ${ }^{\circledR} \mathrm{V}$

PVDF blotting membranes

PVDF blotting membranes Westran ${ }^{\circledR}$

Reaction tubes: $0,2 \mathrm{ml}$

$$
\begin{aligned}
& 0,5 \mathrm{ml} \\
& 1,5 \mathrm{ml} \text { and 2,0 ml }
\end{aligned}
$$

Scalpels

Sephadex ${ }^{\circledR}$ G-50

Single use insulin syringe Omnican 40

Sterile filters $500 \mathrm{ml}$

Sterile filters Minisart NML, $\varnothing 0,45 \mu \mathrm{m}$ and $0,2 \mu \mathrm{m}$

Sterile tubes $10 \mathrm{ml}$

Sterile tubes Falcon ${ }^{\circledR} 50 \mathrm{ml}$

Tubes $5 \mathrm{ml}, 75 \times 13 \mathrm{~mm} \varnothing$

Whatman GB0002 paper

Whatman GB0003 paper, extra thick

X-ray films, XAR-5
Nalgene, München

Corning Inc., NY, USA

Nunc, Wiesbaden

Neoject, Gelnhausen

Schott, Mainz

Schütt, Göttingen

Amersham, Braunschweig

Braun, Melsungen

Sartorius, Göttingen

American National Can ${ }^{\mathrm{TM}}$,

Neenah, USA

Schütt, Göttingen

Sarstedt, Nümbrecht

Molecular Bioproducts inc., San

Diego, USA / Eppendorf,

Hamburg

Labsystems, Helsinki, Finland

Beckmann, München

Zinsser Analytic, Frankfurt/M

Roth, Karlsruhe

Schleicher\&Schuell, Dassel

Perkin-Elmer Cetus, Norwalk,

USA

Sarstedt, Braunschweig

Greiner, Nürtingen

Braun, Melsungen

Pharmacia, Uppsala, Sweden

Becton Dickinson, Heidelberg

Sarstedt, Braunschweig

Sartorius, Göttingen

Greiner, Nürtingen

Sarstedt, Braunschweig

Sarstedt, Braunschweig

Schleicher\&Schuell, Dassel

Schleicher\&Schuell, Dassel

Kodak, Stuttgart

\subsubsection{Chemicals}

If not otherwise indicated, chemicals of per analysis purity were purchased from following companies: Aldrich Chemical Company (Milwaukee, USA), Baker (Deventer, Netherlands), BioRad (München), Boeringer (Mannheim), Calbiochem (Frankfurt), Fluka 
(Buchs, Switzerland), GIBCO/BRL (Eggenstein), Merk (Darmstadt), Pharmacia

(Freiburg), Sigma (Deisenhofen), Serva (Heidelberg) and Roth (Karlsruhe).

Acetic acid

Acetone

Acetonitrile, HPLC

$30 \%$ acrylamide / $0,8 \%$ bisacrylamide

Agar

Agarose for electrophoresis

Ammonium acetate

Bacto-tryptone

Bacto-yeast extract

Bromphenol blue

Calcium chloride

Chloroform

DAKO ${ }^{\circledR}$ mounting media

Dimethylsulfoxide (DMSO), ultra pure

Dithiotreitol (DTT), ultra pure

DL-lactate (disodium salt)

Ethanol

Ethidiumbromide

Ethylendiamintetraacetic acid - disodium salt

(EDTA)

FITC-dextran, MW=14000

Formaldehyde (37\%) solution

Formamide

Glucose

Glycine

HEPES (N-2-Hydroxyethylpiperazine-N'-2-

ethansulfon acid

Liquid scintillation mix Lumasafe Plus

Magnesiumsulfate $\left(\mathrm{MgSO}_{4}\right)$

2-Mercaptoethanol (2-MSH)

Methanol

Morpholinopropanesulfon acid (MOPS)

NZYDT powder

Paraform aldehyde

Percoll $\AA$

Ponceau S solution

Phenol

Potassium chloride $(\mathrm{KCl})$

Rapid hyb buffer

Sodium acetate $(\mathrm{NaAc})$

Sodium azide $\left(\mathrm{NaN}_{3}\right)$

Sodium carbonate $\left(\mathrm{Na}_{2} \mathrm{CO}_{3}\right)$

Sodium chloride $(\mathrm{NaCl})$
Merck

Merck

Baker

Roth

Sigma

Roth

Fluka

Difco

Difco

BioRad

Merck

Merck

Carpinteria, CA, USA

Merck

Serva

Sigma

Merck

Serva

Merck

Sigma

Merck

Fluka

Merck

Roth

Serva

Packard Bioscience, Groningen, Netherlands

Merck

Sigma

Merck

Serva

Difco

Sigma

Amersham Pharmacia

Serva

Fluka

Merck

Amersham

Merck

Sigma

Merck

Roth 
Sodium citrate

Sodium dodecylsulfate (SDS)

Sodium hydrogen carbonate

Sodium hydroxide $(\mathrm{NaOH})$

Sodium pyruvate

Sucrose

TEMED N'N'N'N'Tetramethyethylendiamin

Trichloracetic acid (TCA)

Tris-(hydroxymethyl)-aminomethan (Tris)

Water, HPLC purity grade
Merck

Sigma

Merck

Merck

Merck

Roth

Sigma

Merck

Roth

Baker

\subsubsection{Detergents}

Nonidet - P40

Saponin

Triton X 100

Tween 20

\subsubsection{Enzymes and nucleotides}

Alkaline phosphatase type II: bacterial (from E.coli)

Proteinase K

Restriction endonucleases

RNAse A

T4 - DNA - ligase

Taq - DNA - polymerase

Ultra pure dNTP set
Sigma, Deisenhofen

Sigma, Deisenhofen

Sigma, Deisenhofen

Sigma, Deisenhofen

Boehringer, Deisenhofen

Boehringer, Mannheim

New England Biolabs, Bad

Schwalbach/ MPI Fermentas, St.

Leon- Rot

Boehringer, Mannheim

New England Biolabs, Bad

Schwalbach

Pharmacia, Freiburg

Pharmacia, Freiburg

\subsubsection{Kits for treating of DNA, RNA and proteins}

HiSpeed $^{\mathrm{TM}}$ Plasmid midi kit QIAGEN

Megaprime DNA labelling kit

QIAEX II gel extraction kit

QIAGEN Lambda maxi kit

QIAprep Spin ${ }^{\mathrm{TM}}$ miniprep kit

RNeasy® Protect mini kit

Super Signal ${ }^{\circledR}$ west pico chemiluminiscent substrate
Diagen, Hilden

Amersham, Braunschweig

Diagen, Hilden

Diagen, Hilden

Diagen, Hilden

Diagen, Hilden

PIERCE, Rockford, IL, USA

\subsubsection{Proteins, protease inhibitors and protein standards}

Albumin bovine Fr.V (BSA) standard grade

Asialofetuin

BODIPY ${ }^{\circledR}-L D L$
Serva, Heidelberg

Sigma, Deisenhofen

Molecular probes, USA 
EGF, murine

Gelatine, research grade

Jodacetamide (JAA)

Leupeptin

Pansorbin - cells (heat - inactivated Staphylococcus aureus cells suspension)

Pepstatin A

Phenylmethylsulfonylfluoride (PMSF)

Prestained protein MW - standard
Calbiochem, Frankfurt

Serva, Heidelberg

Serva, Heidelberg

Sigma, Deisenhofen

Calbiochem, Frankfurt

Sigma, Deisenhofen

Serva, Heidelberg

Calbiochem, Frankfurt

\subsubsection{Antibodies}

\subsubsection{Primary antibodies}

\begin{tabular}{|c|c|c|c|}
\hline Antigen & $\begin{array}{l}\text { Immunised } \\
\text { species }\end{array}$ & Preparation & Reference \\
\hline$\gamma$-adaptin & $\begin{array}{c}\text { Mouse, } \\
\text { monoclonal }\end{array}$ & $\begin{array}{l}\text { Affinity purified } \\
\text { (AP) }\end{array}$ & Transduction laboratories \\
\hline $\begin{array}{l}\text { Cathepsin D, } \\
\text { murine }\end{array}$ & $\begin{array}{c}\text { Rabbit, } \\
\text { polyclonal KIIS3 }\end{array}$ & Serum & (Pohlmann et al. 1995) \\
\hline Lamp1, murine & $\begin{array}{c}\text { Rat, monoclonal } \\
\text { 1D4B }\end{array}$ & Hybridoma medium & $\begin{array}{l}\text { Hybridoma Bank, Iowa, } \\
\text { USA;(Kasper et al. 1996) }\end{array}$ \\
\hline Lamp2, murine & $\begin{array}{l}\text { Rat, monoclonal } \\
\text { ABL93 }\end{array}$ & Hybridoma medium & $\begin{array}{l}\text { Hybridoma Bank, Iowa, } \\
\text { USA;(Kasper et al. 1996) }\end{array}$ \\
\hline $\begin{array}{l}\text { LimpII, rat, } \\
\text { luminal domane }\end{array}$ & $\begin{array}{c}\text { Rabbit, } \\
\text { polyclonal, } \\
\text { Igp85 }\end{array}$ & Serum & Tanaka, unpublished \\
\hline $\begin{array}{l}\text { MPR46, } \\
\text { cytoplasmic } \\
\text { domain }\end{array}$ & $\begin{array}{l}\text { Rabbit, } \\
\text { polyclonal }\end{array}$ & $\begin{array}{l}\text { Affinity purified } \\
\text { (AP) }\end{array}$ & (Klumperman et al. 1993) \\
\hline mVtila & $\begin{array}{l}\text { Rabbit, } \\
\text { polyclonal }\end{array}$ & $\begin{array}{l}\text { Serum and affinity } \\
\text { purified (AP) }\end{array}$ & (Antonin et al. 2000c) \\
\hline mVtilb & $\begin{array}{l}\text { Rabbit, } \\
\text { polyclonal }\end{array}$ & $\begin{array}{l}\text { Serum and affinity } \\
\text { purified (AP) }\end{array}$ & (Antonin et al. 2000c) \\
\hline SNAP - 29 & $\begin{array}{l}\text { Rabbit, } \\
\text { polyclonal }\end{array}$ & Serum & (Antonin et al. 2000a) \\
\hline Syntaxin 7 & $\begin{array}{l}\text { Rabbit, } \\
\text { polyclonal }\end{array}$ & Serum & (Antonin et al. 2000a) \\
\hline Syntaxin 8 & $\begin{array}{l}\text { Rabbit, } \\
\text { polyclonal }\end{array}$ & Serum & (Antonin et al. 2000a) \\
\hline $\begin{array}{l}\text { Transferrin } \\
\text { receptor, human }\end{array}$ & $\begin{array}{c}\text { Mouse, } \\
\text { monoclonal }\end{array}$ & $\begin{array}{l}\text { Affinity purified } \\
\text { (AP) }\end{array}$ & ZYMED \\
\hline EGF-R & $\begin{array}{l}\text { Rabbit, } \\
\text { polyclonal }\end{array}$ & (AP) & Santa Cruz Biotech. \\
\hline Adipophilin & $\begin{array}{l}\text { Guinea pig, } \\
\text { polyclonal }\end{array}$ & (AP) & PROGEN \\
\hline
\end{tabular}




\subsubsection{Secondary antibodies}

FITC - conjugated: goat anti mouse, goat anti rabbit, goat anti rat and goat anti guinea pig.

Texas Red conjugated: goat anti mouse, goat anti rabbit and goat anti rat. $\mathrm{Cy} 2$ - conjugated goat anti mouse and anti rabbit.

HRP - conjugated: goat anti mouse, goat anti rabbit, goat anti rat and goat anti guinea pig.

All these antibodies were purchased through Dianova, Hamburg.

\subsubsection{Radioactive substances}

$\alpha-\left[{ }^{32} \mathrm{P}\right]-\mathrm{dCTP}$, Redivue

$3000 \mathrm{Ci} / \mathrm{mmol}$

$\mathrm{L}-\left[{ }^{35} \mathrm{~S}\right]-$ methionine / cystein, aqueous solution

$14 \mathrm{mCi} / \mathrm{mmol}$

$\mathrm{L}-\left[{ }^{14} \mathrm{C}\right]-$ valine, aqueous solution

$263 \mathrm{mCi} / \mathrm{mmol}$

$\mathrm{Na}\left[{ }^{125} \mathrm{I}\right]$ in $\mathrm{NaOH}$ solution

$105 \mathrm{mCi} / \mathrm{ml}$
Amersham- Buchler, Braunschweig

Amersham- Buchler, Braunschweig Amersham- Buchler, Braunschweig Amersham- Buchler, Braunschweig

\subsubsection{Vectors and DNA standard}

pBluescript SK ${ }^{+}$

pCMV - SPORT2, containing mVti1b coding sequence

pT7T3D - Pac, containing mVtila coding sequence Phage $\lambda$ - 2FixII DNA library of sv129 mouse type DNA ladder
Stratagene

AA105524, ATCC, USA

AA16379, ATCC, USA

A gift of Dr. Nils Brose

Gibco/BRL, Eggenstein

\subsubsection{Bacterial strains and embryonic stem cells}

E-14 mouse embryonic stem cell line (type sv129 Ola)

Mouse embryonic fibroblasts, G418 resistant

MPI-ES embryonic stem cells

E.coli XL - blue (genotype $\mathrm{F}^{\prime}:$ :Tn10 pro $\mathrm{A}^{+} \mathrm{B}^{+}$ laq ${ }^{q} \Delta$ (laqZ)M15recA1 endA1 gyrA96( $\left.\mathrm{NaI}^{\mathrm{r}}\right)$ thi hsd $\mathrm{R} 17\left(\mathrm{r}_{\mathrm{k}}^{-} \mathrm{m}_{\mathrm{k}}^{+}\right)$supE44 relA 1 lac $)$ E.coli LE392 (genotype hsdR514 supE44 supF58 lacY1 or $\Delta($ lacIZY)6 galK2 galT22 metB1 trpR55 mcrA lambda')

\subsubsection{Antibiotics}

Ampicilline hydrate
Work group of Dr. K. Rajewsky, Köln (Hooper et al. 1987) BRL, Basel, Switzerland, self prepared

A gift of Dr. Paul Saftig 
Geneticin G418 (Neomycin)

Kanamycin disulfate

Mitomycin C

Penicillin/Streptomycin (100x)

$10000 \mathrm{U} / 10000 \mu \mathrm{g}$ per $\mathrm{ml}$
Gibco/BRL, Eggenstein

Merck

Sigma

Gibco/BRL, Eggenstein

\subsubsection{Mouse strains}

C57BL/6 $\mathrm{J}$ female mice were used as surrogate mothers and for crossing with chimerical males (Source: BRL, Basel, Switzerland).

\subsubsection{Frequently used buffers and stock solutions}

\begin{tabular}{|c|c|}
\hline $\begin{array}{l}50 \mathrm{x} \\
\mathrm{TAE}:\end{array}$ & $\begin{array}{l}2 \mathrm{M} \text { Tris-base } \\
0,1 \mathrm{M} \text { EDTA } \\
\text { adjust } \mathrm{pH} 8,0 \text { with acetic acid }\end{array}$ \\
\hline TE: & $\begin{array}{l}\text { 10mM Tris/HCl } \mathrm{pH} 8,0 \\
1 \mathrm{mM} \text { EDTA }\end{array}$ \\
\hline TBS: & $\begin{array}{l}150 \mathrm{mM} \mathrm{NaCl} \\
50 \mathrm{mM} \text { Tris/HCl pH 7,4 }\end{array}$ \\
\hline $\begin{array}{l}\mathrm{M} \\
\text { Tris/HCl }\end{array}$ & $\begin{array}{l}12,1 \mathrm{~g} \text { Tris }- \text { base were dissolved in } 80 \mathrm{ml} \text { bidistilled } \mathrm{H}_{2} \mathrm{O}, \mathrm{pH}-\text { value }(7,4 ; \\
7,5 ; 8,0 ; 8,5 \text { or } 9,0) \text { was adjusted and volume was enlarged till } 100 \mathrm{ml}\end{array}$ \\
\hline $\begin{array}{l}10 \% \\
\text { SDS: }\end{array}$ & $\begin{array}{l}100 \mathrm{~g} \text { Sodium dodecylsulfate were dissolved in } 1000 \mathrm{ml} \text { bidistilled } \mathrm{H}_{2} \mathrm{O} \text { at } \\
65^{\circ} \mathrm{C}\end{array}$ \\
\hline $\begin{array}{l}0,5 \mathrm{M} \\
\text { EDTA: }\end{array}$ & $\begin{array}{l}\text { 18,1 } \mathrm{g} \text { Disodiumethylendiamintetraacetate } \times 2 \mathrm{H}_{2} \mathrm{O} \text { were in } 80 \mathrm{ml} \text { bidistilled } \\
\mathrm{H}_{2} \mathrm{O} \text { upon addition of several drops of concentrated } \mathrm{NaOH}, \mathrm{pH} 8,0 \text { was } \\
\text { adjusted with concentrated } \mathrm{NaOH} \text { and volume enlarged till } 100 \mathrm{ml}\end{array}$ \\
\hline $\begin{array}{l}3 \mathrm{M} \\
\mathrm{NaAc}:\end{array}$ & $\begin{array}{l}\text { 40,8 g Sodium acetate } \times 3 \mathrm{H}_{2} \mathrm{O} \text { were dissolved in } 80 \mathrm{ml} \mathrm{H}_{2} \mathrm{O} \text {, pH 5,2 was } \\
\text { adjusted with ice acetic acid and volume enlarged till } 100 \mathrm{ml}\end{array}$ \\
\hline $\begin{array}{l}20 \mathrm{x} \\
\text { SSC: }\end{array}$ & $\begin{array}{l}175,3 \mathrm{~g} \mathrm{NaCl} \\
88,2 \mathrm{~g} \mathrm{Na}-\mathrm{Citrate} \\
\text { were dissolved in } 800 \mathrm{ml} \mathrm{H}_{2} \mathrm{O}, \mathrm{pH} 7,0 \text { was adjusted with concentrated } \mathrm{HCl} \\
\text { and volume enlarged till } 1000 \mathrm{ml}\end{array}$ \\
\hline $\begin{array}{l}\text { 10X } \\
\text { PBS: }\end{array}$ & $\begin{array}{l}80 \mathrm{~g} \mathrm{NaCl} \\
1,6 \mathrm{~g} \mathrm{Na}_{2} \mathrm{HPO}_{4} \\
\text { were dissolved in } 800 \mathrm{ml} \text { bidistilled } \mathrm{H}_{2} \mathrm{O}, \mathrm{pH} 7,4 \text { was adjusted and volume } \\
\text { enlarged till } 1000 \mathrm{ml}\end{array}$ \\
\hline CI: & $\mathrm{d}$ isoamylalcohol were mixed in proportion of $24: 1$ \\
\hline
\end{tabular}




\subsubsection{Media for cultivation of bacteria and phage $\lambda$}

\begin{tabular}{|c|c|}
\hline LB - medium: & $\begin{array}{l}10 \mathrm{~g} \text { bactotrypton } \\
5 \mathrm{~g} \text { bacto yeast extract } \\
5 \mathrm{~g} \mathrm{NaCl} \\
\text { were dissolved in } 800 \mathrm{ml} \text { bidistilled } \mathrm{H}_{2} \mathrm{O}, \mathrm{pH} 7,5 \text { was adjusted and } \\
\text { volume enlarged till } 1000 \mathrm{ml} \text {, autoclaved }\end{array}$ \\
\hline $\begin{array}{l}\text { LB - medium } \\
\text { for host bacteria }\end{array}$ & $\begin{array}{l}10 \mathrm{~g} \text { bactotrypton } \\
5 \mathrm{~g} \text { bacto yeast extract } \\
5 \mathrm{~g} \mathrm{NaCl} \\
\text { were dissolved in } 800 \mathrm{ml} \text { bidistilled } \mathrm{H}_{2} \mathrm{O}, \mathrm{pH} 7,5 \text { was adjusted and } \\
\text { volume enlarged till } 1000 \mathrm{ml} \text {, autoclaved. The mixture was stored at } \\
4^{0} \mathrm{C} \text {. } \\
\mathrm{MgSO}_{4} \times 7 \mathrm{H}_{2} \mathrm{O} \text { solution sterile (till } 10 \mathrm{mM} \text { ) and } \\
\mathrm{x} \mathrm{ml} \mathrm{sterile} \mathrm{Maltose} \mathrm{solutions} \mathrm{(till} 0,2 \% \text { ) were added before use }\end{array}$ \\
\hline $\begin{array}{l}\text { LB - ampicillin } \\
\text { and kanamycin } \\
\text { agar plates: }\end{array}$ & $\begin{array}{l}\text { For cultivation of bacterial transformants, the } \mathrm{LB}-\text { medium was } \\
\text { supplemented by agar (end concentration } 1,5 \% \text { ) and then } \\
\text { autoclaved. The liquid was chilled till approx. } 50^{0} \mathrm{C} \text { and ampicillin } \\
\text { or kanamycin was added (end concentration } 200 \mu \mathrm{g} / \mathrm{ml} \text { ). The } \\
\text { mixture was transferred into } 10 \mathrm{~cm} \text { plates, cooled at RT and stored at } \\
4^{0} \mathrm{C} \text {. }\end{array}$ \\
\hline $\begin{array}{l}\text { NZYDT agar } \\
\text { plates: }\end{array}$ & $\begin{array}{l}21,1 \mathrm{~g} \text { NZYDT powder } \\
15 \mathrm{~g} \text { agar } \\
\text { were mixed in } 1000 \mathrm{ml} \text { bidistilled } \mathrm{H}_{2} \mathrm{O} \text { and autoclaved. The mixture } \\
\text { was transferred into } 10 \mathrm{~cm} \text { and } 15 \mathrm{~cm} \text { plates, cooled at RT and stored } \\
\text { at } 4^{0} \mathrm{C} \text {. }\end{array}$ \\
\hline $\begin{array}{l}\text { NZYDT top - } \\
\text { agarose for } \\
\text { NZYDT agar } \\
\text { plates: }\end{array}$ & $\begin{array}{l}21,1 \mathrm{~g} \text { NZYDT powder } \\
7 \mathrm{~g} \text { agarose for electrophoresis } \\
\text { were mixed in } 1000 \mathrm{ml} \text { bidistilled } \mathrm{H}_{2} \mathrm{O} \text { and autoclaved. The mixture } \\
\text { was stored at } 4^{0} \mathrm{C} \text {. }\end{array}$ \\
\hline SM - buffer: & $\begin{array}{l}5,8 \mathrm{~g} \mathrm{NaCl} \\
2 \mathrm{~g} \mathrm{MgSO}_{4} \times 7 \mathrm{H}_{2} \mathrm{O} \\
50 \mathrm{ml} 1 \mathrm{M} \text { Tris }-\mathrm{HCl} \mathrm{pH} \mathrm{7,5} \\
\text { were mixed in } 1000 \mathrm{ml} \text { bidistilled } \mathrm{H}_{2} \mathrm{O} \text { and autoclaved, afterwards } 5 \\
\text { ml } 2 \% \text { gelatine were added. }\end{array}$ \\
\hline
\end{tabular}

\subsubsection{Media for eucaryotic cell culture and solutions for treating of these cells}

\begin{tabular}{|l|l|}
\hline Cryogenic conservation medium for ES cells & $60 \%$ DMEM \\
& $20 \%$ FKS (Boehringer) \\
& $20 \%$ DMSO \\
\hline Dulbeccos Modified Eagles Medium (DMEM) & Gibco BRL , Eggenstein \\
\hline Electroporation buffer for ES cells & $20 \mathrm{mM} \mathrm{HEPES} \mathrm{pH} \mathrm{7,0}$ \\
& $137 \mathrm{mM} \mathrm{NaCl}$ \\
\hline
\end{tabular}




\begin{tabular}{|c|c|}
\hline & $\begin{array}{l}0,7 \mathrm{mM} \mathrm{Na}_{2} \mathrm{HPO}_{4} \\
6 \mathrm{mM} \text { glucose } \\
0,1 \mathrm{mM} \beta \text {-mercaptoethanol } \\
\text { Sterile filtered and stored at } \\
-20^{\circ} \mathrm{C}\end{array}$ \\
\hline Fetal calf serum (FKS) & $\begin{array}{l}\text { Gibco BRL, Eggenstein } \\
\text { Boehringer, Mannheim }\end{array}$ \\
\hline $\mathrm{L}$ - glutamine $(200 \mathrm{mM})$ & Gibco BRL, Eggenstein \\
\hline $\mathrm{LIF}$ - factor $\mathrm{ESGRO}^{\mathrm{TM}}$ & $\begin{array}{l}\text { Chemicon International, Inc., } \\
\text { CA, USA }\end{array}$ \\
\hline $\begin{array}{l}\text { Medium for "DNA"- mouse embryonic stem cells } \\
(\mathrm{E}-14) \text { culture }\end{array}$ & $\begin{array}{l}\text { DMEM } \\
15 \% \text { FKS Gibco } \\
2 \mathrm{mM} \mathrm{L} \text {-glutamine } \\
100 \mathrm{U} / \mathrm{ml} \\
\text { Penicilline/Streptomycin } \\
1 \mathrm{x} \text { sodium pyruvate } \\
1 \mathrm{x} \text { non essential aminoacids } \\
0,5 \mathrm{ml} \text { ß-mercaptoethanol } \\
335 \mu \mathrm{g} / \mathrm{ml} \mathrm{G} 418\end{array}$ \\
\hline $\begin{array}{l}\text { Medium for mouse embryonic fibroblasts (MEF) } \\
\text { culture }\end{array}$ & $\begin{array}{l}\text { DMEM } \\
10 \% \text { FKS Gibco BRL } \\
2 \mathrm{mM} \mathrm{L}-\text { glutamine } \\
100 \mathrm{U} / \mathrm{ml} \\
\text { Penicilline/Streptomycin } \\
\end{array}$ \\
\hline $\begin{array}{l}\text { Medium for mouse embryonic stem cells }(\mathrm{E}-14) \\
\text { culture }\end{array}$ & $\begin{array}{l}\text { DMEM } \\
15 \% \text { FKS Boehringer } \\
2 \mathrm{mM} \mathrm{L} \text {-glutamine } \\
100 \mathrm{U} / \mathrm{ml} \\
\text { Penicilline/Streptomycin } \\
1 \mathrm{x} \text { sodium pyruvate } \\
1 \mathrm{x} \text { non essential aminoacids } \\
0,5 \mathrm{ml} ß \text {-mercaptoethanol } \\
5 \times 10^{5} \text { Units LIF-factor } \\
\end{array}$ \\
\hline Non essential aminoacids (100x) & Gibco BRL, Eggenstein \\
\hline PBS (for ES cell culture) & Gibco BRL, Eggenstein \\
\hline PBS (for fibroblast cell culture) & $\begin{array}{l}150 \mathrm{mM} \mathrm{NaCl} \\
120 \mathrm{mM} \mathrm{KCl} \\
10 \mathrm{mM} \mathrm{Na}_{2} \mathrm{HPO}_{4} / \mathrm{KH}_{2} \mathrm{PO}_{4}, \mathrm{pH} \\
7,4 \\
0,002 \%(\mathrm{w} / \mathrm{v}) \text { phenol red }\end{array}$ \\
\hline Sodium pyruvate(100x) & Gibco BRL, Eggenstein \\
\hline B-mercaptoethanol & $\begin{array}{l}35 \mu \mathrm{l} \text { diluted in } 5 \mathrm{ml} \text { PBS were } \\
\text { sterile filtered to obtain } 1000 \mathrm{x} \\
\text { solution }\end{array}$ \\
\hline
\end{tabular}




\begin{tabular}{|l|l|}
\hline Trypsin/EDTA solution & $0,05 \%(\mathrm{w} / \mathrm{v})$ trypsin \\
& $0,02 \%(\mathrm{w} / \mathrm{v})$ EDTA \\
& in Puck's modified salt solution \\
& Gibco BRL, Eggenstein \\
\hline
\end{tabular}

\subsubsection{Hardware and software}

Hardware:

Apple laser writer 16/600 PS

iMac

Laser Jet $4050 \mathrm{~N}$

PC type pentium III

Scanner ScanJet 4C/T

Apple computers

Apple computers

Hewlett Packard, Palo Alto, USA

IBM compatible

Hewlett Packard, Palo Alto , USA

Software:

Windows 98SE

Microsoft

Word 2000

Microsoft

Adobe Photoshop 5.5

Adobe Systems

Cricket III pro

Computer Associates Int.

Image Reader

Fuji

Image Gauge

Fuji

AIDA

Fuji 


\subsection{Methods of molecular biology}

\subsubsection{Methods of DNA treatment}

If not otherwise indicated, all following methods were taken from laboratory manual "Molecular cloning" of (Sambrook et al. 1989).

\subsubsection{Precipitation of DNA with ethanol}

A volume of DNA was determined and concentration of $\mathrm{Na}$ - Acetate was adjusted till 0,3 $\mathrm{M}$, then 2 volumes of ethanol were added and mixed. The precipitation proceeds 20 minutes at $-70^{\circ} \mathrm{C}, 10$ minutes on dry ice or overnight at $-20^{\circ} \mathrm{C}$. DNA was pelleted for 10 minutes at $12000 \mathrm{x} \mathrm{g}$, then washed in $70 \%$ ethanol and centrifuged again for 5 minutes. The DNA precipitate was dried on air for $5-15$ minutes.

\subsubsection{Phenol/chloroform/isoamylalcohol extraction of DNA}

This is a standard method of treating DNA. An equal volume of Phenol/ chloroform/ isoamylalcohol (25/24/1 mixture) was added to DNA solution, shaked till emulsion was formed and centrifuged for 3-5 minutes. Upper phase was removed and kept for downstream preparations.

\subsubsection{Determination of DNA concentration}

A photometric estimation of DNA concentration was done at $260 \mathrm{~nm}$ in quartz cuvette against $\mathrm{H}_{2} \mathrm{O}$. One OD corresponds a concentration of $50 \mu \mathrm{g} / \mathrm{ml}$ of double-stranded DNA and $31 \mu \mathrm{g} / \mathrm{ml}$ of oligonucleotides.

\subsubsection{Purification of DNA using Sephadex ${ }^{\circledR}$ G50}

Sephadex ${ }^{\circledR}$ G50: $\quad$ 5g Sephadex G50 were mixed with $50 \mathrm{ml} \mathrm{TE}$ and autoclaved.

Gelfiltration through Sephadex G50 was done for removing of unbound radioactive nucleotides and salts from DNA labelled probes.

A blue pipette tip was plugged with siliconised glas fibres and filled with Sephadex suspension (ca. $1 \mathrm{ml}$ ). The tip was put in a $5 \mathrm{ml}$ plastic tube and centrifuged in a $10 \mathrm{ml}$ cell culture tube for 2 minutes at $3000 \mathrm{rpm}$. A new portion of Sephadex was filled in the same 
tip and centrifuged again. Eluates were thrown away. DNA probe $(200 \mu 1)$ labelled by Ready Prime ${ }^{\mathrm{TM}}$ was transferred onto the Sephadex column and again centrifuged for 4 minutes at $3000 \mathrm{rpm}$. The flow-through was transferred in an eppendorf tube, the volume determined and incorporation of radioactive nucleotides in DNA probe was determined in a ß-counter using Cerenkov coefficient (Berger 1984).

\subsubsection{Restriction digestion of DNA with endonucleases}

An activity of restriction endonucleases is estimated in units $(\mathrm{U})$. One unit corresponds to an amount of enzyme, which is enough for digestion of $1 \mu \mathrm{g}$ of lambda phage DNA completely in one hour on all available sites. To be sure that restriction digestion proceed quantitatively, the amount of enzyme and the incubation time will be increased by factor of two.

\section{Reaction mix for digestion of plasmid DNA:}

$\begin{array}{ll}\mathrm{x} \mu \mathrm{g} & \text { DNA } \\ 2 \mu \mathrm{l} & \text { corresponding 10x buffer (for ex. N1 - } \\ & \text { N4) } \\ 2 \mathrm{x} \mathrm{x} \mathrm{U} & \text { restriction endonuclease } \\ \text { adjust to } & \text { double distillated } \mathrm{H}_{2} \mathrm{O} \\ 20 \mu \mathrm{l} & \end{array}$

The mixture was incubated for 2 hours at $37^{\circ} \mathrm{C}$ and then analysed in an agarose gel. Preparative restriction digestions were done in bigger volumes and with increased amounts of enzymes.

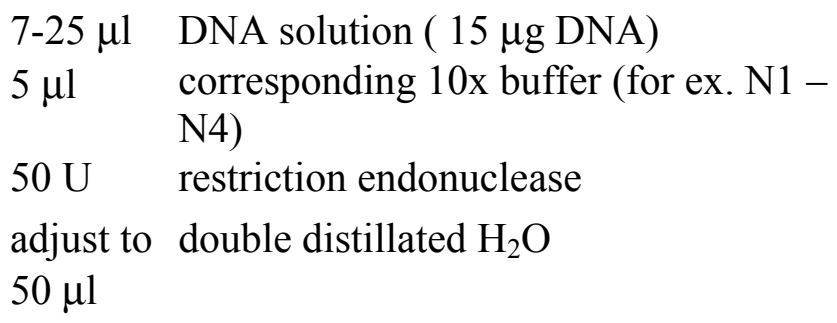

\section{Reaction mix for digestion of genomic DNA:}

The mixture was incubated overnight at $37^{\circ} \mathrm{C}$ and then used completely to separate fragments in an agarose gel for southern blot analysis.

As reaction buffers, New England Biolabs buffers were used (NEB). These buffers were 10x concentrated by supplier and purchased together with enzymes. 


\subsubsection{DNA ligation}

Plasmid vector pBluescript $\mathrm{SK}^{+}$was cut at an appropriate polylinker site. A desired fragment was cut out from the DNA of interest. Both, the vector and the desired fragment were extracted from agarose gels using the QIAEXII kit (QIAGEN). The amounts of DNA in the eluates were estimated on agarose gels (ethidium bromide staining is proportional to the amount of base pairs). 1,5 $\mu 1$ of 10x ligase buffer were mixed with the vector and fragment eluates, the volume was adjusted with double distilled $\mathrm{H}_{2} \mathrm{O}$ to $14 \mu \mathrm{l}$ and $1 \mu \mathrm{l}$ of T4 DNA ligase was added. The mixture was incubated at $14^{\circ} \mathrm{C}$ overnight and then used for E.coli transformation.

\subsubsection{Phosphatase treatment of digested plasmid DNA}

To prevent re-ligation of single digested plasmids, they were treated with alkaline phosphatase. $5 \mu \mathrm{g}$ plasmid DNA was digested with the desired endonuclease for $2-3$ hours in $50 \mu \mathrm{l}$ reaction volume. $2 \mu \mathrm{l}$ of alkaline phosphatase (Boehringer) were added (if digestion was done in the buffer N1, $5 \mu$ of 10x buffer N3 were added simultaneously) and the reaction mix was incubated for 1 hour at $37^{0} \mathrm{C}$. Then $0,5 \mu \mathrm{l}$ of $500 \mathrm{mM}$ EDTA (final concentration should be $5 \mathrm{mM}$ ) were added and heated for 20 minutes at $75^{\circ} \mathrm{C}$. A preparative agarose gel was run and a plasmid extracted accordingly to QIAEXII (QIAGEN) kit protocol.

\subsubsection{Site-directed mutagenesis}

For introduction of new restriction sites into cloned genomic fragments of interest an oligonucleotide directed mutagenesis was used.

\section{Primer construction}

A pair of PCR primers was constructed to amplify plasmid completely so that on the 5' end and on the complimentary on 3' end they would introduce a new or destroy an existing restriction site. The mutation in a plasmid can be monitored in comparison with native one by restriction digestion.

\section{Phosphorylation of primers}

To allow ligation at the end of the procedure primers were phosphorylated: 


\begin{tabular}{|c|c|}
\hline $\begin{array}{l}1 \mu 1 \\
1 \mu 1 \\
1 \mu 1 \\
6 \mu 1 \\
1 \mu 1\end{array}$ & $\begin{array}{l}200 \text { pmol of the primer } 1 \text { (same } \\
\text { for primer 2) } \\
10 x \text { T4 kinase buffer } \\
10 \text { mM ATP } \\
\text { dd water } \\
\text { T4 kinase }\end{array}$ \\
\hline & $\begin{array}{l}\text { hix was incubated for } 30 \\
\text { C }\end{array}$ \\
\hline
\end{tabular}

\title{
PCR
}

Pfu DNA polymerase was used because it has low rate of mistakes. The Pfu DNA polymerase needs 2 minutes to amplify $1 \mathrm{~kb}$.

$\begin{array}{llll}1 \mu \mathrm{l} & 1: 10 \text { or } 1: 50 \text { diluted plasmid } & \text { PCR cycles, example: } \\ 5 \mu \mathrm{l} & \text { 10x Pfu buffer } & & \\ 5 \mu \mathrm{l} & \text { dNTP } & & \\ 1,5 \mu \mathrm{l} & \text { primer } 1-\mathrm{PO}_{4} & 1 \mathrm{~min} & 95^{\circ} \mathrm{C} \\ 1,5 \mu \mathrm{l} & \text { primer } 2-\mathrm{PO}_{4} & 1 \mathrm{~min} & 52^{\circ} \mathrm{C} \\ 35 \mu \mathrm{l} & \mathrm{H}_{2} \mathrm{O} & 10 \mathrm{~min} & 72^{0} \mathrm{C}\end{array}$

The reaction mix was incubated 4 minutes at $95^{\circ} \mathrm{C}$, then $1 \mu \mathrm{Pfu}$ was $\quad 10$ cycles total $(\max 12)$ added

\section{DpnI restriction digestion}

To eliminate native unchanged plasmid, the restriction enzyme DpnI was used, which digests only methylated DNA. $1 \mu 1$ of DpnI was added after the PCR reaction indicated above and the reaction incubated for 1 hour at $37^{\circ} \mathrm{C}$. For inactivation of the enzyme the tube was heated for 30 minutes at $80^{\circ} \mathrm{C} .12,5 \mu$ of the reaction were used directly for ligation or the mixture was loaded on preparative agarose gel and a fragment of interest was extracted using the QIAEXII method.

\section{Ligation}

\author{
$12,5 \mu \mathrm{l} \quad$ DNA \\ $1,5 \mu 1 \quad 10 x$ ligase buffer \\ $1 \mu \mathrm{l} \quad$ concentrated T4 ligase \\ The mixture was incubated at \\ $16^{\circ} \mathrm{C}$ overnight and used for E.coli \\ transformation
}




\subsubsection{DNA isolation}

\subsubsection{Mini preparation of plasmid DNA}

\begin{tabular}{|c|c|}
\hline Lysozyme solution & $\mathrm{NaOH}$ / SDS solution \\
\hline $\begin{array}{l}50 \mathrm{mM} \text { glucose } \\
10 \mathrm{mM} \text { EDTA } \\
25 \mathrm{mM} \text { Tris- } \mathrm{HCl} \mathrm{pH} 8.0 \\
\left(\text { store at } 4{ }^{0} \mathrm{C} \text { ) }\right.\end{array}$ & $\begin{array}{l}0,2 \mathrm{M} \mathrm{NaOH} \\
1 \% \text { SDS } \\
\text { (prepare fresh) }\end{array}$ \\
\hline
\end{tabular}

Two $\mathrm{ml}$ of LB medium containing $200 \mu \mathrm{g} / \mathrm{ml}$ ampicilline were inoculated with a single bacterial colony from a LB - plate and an overnight culture was obtained. 1,5 $\mathrm{ml}$ of the suspension was transferred into an eppendorf tube and centrifuged for 2 minutes at 13000 rpm. The liquid phase was removed and the pellet was resuspended in $100 \mu$ of lysozyme solution. The mixture was incubated for 5 minutes on ice, then $200 \mu 1$ of $\mathrm{NaOH} / \mathrm{SDS}$ solution were added and mixed gently by inversion. A viscous lysate was incubated at RT for 10 minutes and $150 \mu \mathrm{l}$ of $3 \mathrm{M} \mathrm{NaAc}(\mathrm{pH} 5,2)$ pipetted into a tube, followed by incubation on ice for 10 minutes. The obtained fluffy solution was centrifuged 10 minutes in microfuge on high at RT. The supernatant was transferred into a new tube. If nessesary, the DNA was purified by a phenol/chlorophorm extraction. $1 \mathrm{ml}$ (2,5 volumes) cold $100 \%$ ethanol were added to the supernatant and then centrifuged 15 minutes in microfuge at $4{ }^{0} \mathrm{C}$ on high. The supernatant was then aspirated off and $0,5 \mathrm{ml}$ of cold $70 \%$ ethanol were added and span for 5 minutes. The liquid phase was removed and pellet was dried at $37^{\circ} \mathrm{C}$ for 30 minutes. The dry pellets were dissolved in $40 \mu \mathrm{l}$ of TE containing $100 \mu \mathrm{g} / \mathrm{ml}$ RNAse A and used for restriction digestion analysis.

\subsubsection{Mini preparation of plasmid DNA (QIAGEN method)}

Plasmid preparations for later preparative usage were done accordingly to protocols and using the original mini prep QIAGEN reagents (QIAGEN handbook, April 1997). $2-5$, or $10 \mathrm{ml}$ of LB medium (depending on copy number of the plasmid used for transformation) with $200 \mu \mathrm{g} / \mathrm{ml}$ ampicilline were inoculated with a single E.coli bacterial colony from LB - plate and an overnight culture was obtained. The whole amount of the overnight culture was centrifuged in a Megafuge 1.0 for 5 minutes at $5000 \mathrm{rpm}$. The cell 
pellets were resuspended in $250 \mu 1$ of $\mathrm{P} 1$ buffer $\left(4^{0} \mathrm{C}\right)$, mixed with $250 \mu 1$ of buffer P2 and incubated for 5 minute at RT. After addition of $350 \mu 1$ buffer P3 and mixing, a cloudy solution was centrifuged for 10 minutes at $13000 \mathrm{rpm}$ at RT. The supernatant was loaded onto mini-column and centrifuged for 1 minute at $13000 \mathrm{rpm}$. The flow-through was thrown away and $750 \mu$ of PE buffer were loaded onto column followed by a centrifugation for 1 minute again. The flow-through was again thrown away and the column was centrifuged for 1 minute to remove traces of ethanol. To elute DNA, $50 \mu 1$ of $10 \mathrm{mM}$ Tris-HCl, $\mathrm{pH}=8,5$ were added and the column left for 5 minutes. The column was centrifuged and the DNA concentration was determined in the eluate.

\subsubsection{Midi preparation of plasmid DNA (QIAGEN method)}

Plasmid preparations for preparative usage were done accordingly to protocols and using original midi prep QIAGEN reagents (QIAGEN handbook, April 1997).

Using a sterile toothpick, a bit of a culture frozen in 7\% DMSO was transferred into $5 \mathrm{ml}$ LB-ampicilline medium and incubated at $37^{\circ} \mathrm{C}$ for $6-8$ hours. 100 or $500 \mathrm{ml}$ of LB medium (depending on copy number of the plasmid used for transformation) with $200 \mu \mathrm{g} / \mathrm{ml}$ ampicilline were inoculated with 100 or $500 \mu \mathrm{l}$ E.coli bacterial suspension and an overnight culture was obtained. The whole volume was centrifuged at $8000 \mathrm{rpm}$ for 10 minutes in a JA-10 rotor. The pellet was resuspended in 4 $\mathrm{ml}$ of P1 buffer and transferred into JA-20 centrifuge tubes. $4 \mathrm{ml}$ of P2 buffer were added to the suspension and mixed followed by incubation for 5 minutes at RT. The mixture was neutralised by addition of $4 \mathrm{ml}$ of $\mathrm{P} 3$ buffer and incubated then for 20 minutes on ice. After that the lysate was centrifuged 30 minutes at $18000 \mathrm{rpm}$ in JA-20 rotor at $4^{0} \mathrm{C}$ and a supernatant loaded onto a type 100 column equilibrated by QBT-buffer. The plasmid DNA binds to the QIAGEN resin in these columns. The column was washed with $10 \mathrm{ml}$ QCbuffer and the DNA eluted in $5 \mathrm{ml}$ of QF-buffer and collected in a Corex ${ }^{\circledR}$ tube. The DNA was precipitated with 0,7 volumes of isopropanol and centrifuged at $18000 \mathrm{rpm}$ for 30 minutes at $4^{0} \mathrm{C}$. The pellet was washed with $70 \%$ ethanol twice, air-dried and resuspended in 300-500 $\mu \mathrm{l}$ of $10 \mathrm{mM}$ Tris-HCl, $\mathrm{pH} 8,5$. Finally, the concentration of the DNA was determined at OD $260 \mathrm{~nm}$. 


\subsubsection{Maxi preparation of phage $\lambda$ DNA (QIAGEN method)}

An E.coli LE392 culture was grown overnight in $5 \mathrm{ml} \mathrm{NZYDT} \mathrm{supplemented} \mathrm{with} 10 \mathrm{mM}$ $\mathrm{Mg}_{2} \mathrm{SO}_{4}$ and $0,2 \%$ maltose. The culture was diluted with $45 \mathrm{ml}$ of the same medium and grown for more then 1 hour upon measuring of OD $600 \mathrm{~nm}$ (should be below 2, one OD is $8 \times 10^{8}$ cells). To reach a ratio of bacteria / phages of $30 / 1,10^{10}$ cells were infected with $3,3 \times 10^{8}$ pfu $\lambda$ phages for 30 minutes at $37^{0} \mathrm{C}$ without shaking. The mix was added to 250 $\mathrm{ml}$ of NZYDT supplemented with $10 \mathrm{mM} \mathrm{Mg}_{2} \mathrm{SO}_{4}$ and $0,2 \%$ maltose and grown till complete lysis (6 - 8 hours) at $37^{0} \mathrm{C}$ in a shaking incubator. $5 \mathrm{ml}$ of chloroform $(2 \%)$ were added to the lysate and incubated for 15 minutes at $37^{\circ} \mathrm{C}$. The lysate was span down for 15 minutes at $8000 \mathrm{rpm}$ in a JA 10 rotor and the supernatant treated accordingly to QIAGEN lambda handbook. To $250 \mathrm{ml}$ supernatant $400 \mu \mathrm{l}$ of buffer L1 were added and incubated for 30 minutes at $37^{\circ} \mathrm{C}$. During this time all bacterial RNA and chromosomal DNA are digested. $50 \mathrm{ml}$ of ice-cold buffer L2 were added to the lysate and incubated on ice for 60 minutes. Buffer L2 contains PEG for precipitation of the phage particles. The mixture was centrifuged at $18000 \mathrm{rpm}$ for 10 minutes and the supernatant was discarded. The pellet was resuspended in $9 \mathrm{ml}$ of buffer L3 by pipetting up and down and $9 \mathrm{ml}$ of buffer L4 were added. The mixture was incubated at $70^{\circ} \mathrm{C}$ for 20 minutes and then cooled on ice. Buffer L4 contains SDS which denatures phage proteins and releases the DNA. $9 \mathrm{ml}$ of buffer L5 were added to the liquid and immediately but gently mixed by inverting the tube 6 times and then centrifuged for 30 minutes, $4^{0} \mathrm{C}$ at $18000 \mathrm{rpm}$. The supernatant was transferred promptly to a fresh tube and the step repeated for 10 minutes. The obtained clear liquid was loaded onto a QIAGEN tip 500 equilibrated by QBT buffer and allowed it to enter the resin by gravity flow. The tip was washed with $30 \mathrm{ml}$ of buffer QC and the DNA was eluted in $15 \mathrm{ml}$ of buffer QF. The DNA was precipitated by adding of 10,5 $\mathrm{ml}$ of roomtemperature isopropanol and centrifuged at $18000 \mathrm{rpm}$ for 30 minutes at $4^{0} \mathrm{C}$. The obtained pellet was washed twice with room temperature $70 \%$ ethanol and centrifuged each time for 5 minutes at $18000 \mathrm{rpm}$ for 10 minutes. The supernatant was removed and the pellet airdried for 15 minutes followed by redissolving it in $300 \mu \mathrm{l}$ of $10 \mathrm{mM}$ tris- $\mathrm{HCl}, \mathrm{pH} 8,5$. Finally, a concentration of the DNA was determined at OD $260 \mathrm{~nm}$. 


\subsubsection{Genomic DNA isolation from mouse tissues}

\begin{tabular}{|l|l|}
\hline Digestion buffer & for $50 \mathrm{ml}:$ \\
& \\
\hline $100 \mathrm{mM} \mathrm{NaCl}$ & $1 \mathrm{ml} 5 \mathrm{M} \mathrm{NaCl}$ \\
$10 \mathrm{mM}$ Tris-HCl pH 8.0 & $500 \mu 11 \mathrm{M}$ \\
$25 \mathrm{mM}$ EDTA & $2,5 \mathrm{ml} 0,5 \mathrm{M}$ \\
$0,5 \%$ SDS & $2,5 \mathrm{ml} 10 \%$ \\
\hline \multicolumn{2}{|l|}{ directly before use add $0,1 \mathrm{mg} / \mathrm{ml}$ proteinase $\mathrm{K}$} \\
\hline
\end{tabular}

Mouse liver or kidney was cut into small pieces, put into a mortar filled with liquid nitrogen and grind with a pestle. Obtained powder was filled into a $15 \mathrm{ml}$ tube weighted before and weight of it was determined. For every $100 \mathrm{mg}$ tissue $1,2 \mathrm{ml}$ of digestion buffer were added and the mixture was incubated for $12-18$ hours at $56^{\circ} \mathrm{C}$ in a water bath. A sample was extracted twice with equal amounts of phenol / chloroform and spun for 5 minutes at $3000 \mathrm{rpm}$ in a cold room. A blue pipette tip was cut off and the viscous supernatant was transferred into a new tube. Two volumes of cold $100 \%$ ethanol were added, after that DNA pellet was seen. The DNA pellet was fished out of the tube with a a a glass hook molten from a pasteur pipette and washed twice in $500 \mu 1$ of $70 \%$ ethanol. The pellet was air-dried for 15 minutes and dissolved in $500 \mu \mathrm{l}$ of $10 \mathrm{mM}$ Tris- $\mathrm{HCl} \mathrm{pH} 8,5$ during an incubation of 3 hours at $37^{\circ} \mathrm{C}$. The concentration of the DNA was determined at OD $260 \mathrm{~nm}$ and $15 \mu \mathrm{g}$ were used for a restriction digestion.

\subsubsection{DNA isolation from embryonic stem cells}

\begin{tabular}{|l|l|}
\hline NET - buffer & for $50 \mathrm{ml}:$ \\
\hline $100 \mathrm{mM} \mathrm{NaCl}$ & $1 \mathrm{ml} 5 \mathrm{M} \mathrm{NaCl}$ \\
$10 \mathrm{mM}$ Tris-HCl pH 8.0 & $500 \mu 11 \mathrm{M}$ \\
$25 \mathrm{mM}$ EDTA & $2,5 \mathrm{ml} 0,5 \mathrm{M}$ \\
\hline
\end{tabular}

Proteinase $\mathrm{K}$ solution $2 \mathrm{mg} / \mathrm{ml}$ in NET buffer, store at $-20^{0} \mathrm{C}$

Frozen cell pellet were resuspended in $700 \mu$ of NET-buffer using a vortex. $70 \mu 1$ of proteinase $\mathrm{K}$ solution were added and vortexed, then $70 \mu \mathrm{l}$ of $10 \%$ SDS were added and 
vortexed again. The mixture was incubated for $3-4$ hours at $56^{\circ} \mathrm{C}$ followed by a new addition of proteinase $\mathrm{K}$ solution. The obtained lysate was incubated overnight at $56{ }^{\circ} \mathrm{C}$, extracted with phenol / chloroform / isoamylalcohol, with chloroform / isoamylalcohol and the DNA was precipitated upon addition of 3 volumes of $100 \%$ ethanol. The DNA pellet was fished out with a glass hook molten from a pasteur pipette, washed twice with $70 \%$ ethanol and air - dried for 15 minutes. Depending on amount of the pellet, it was

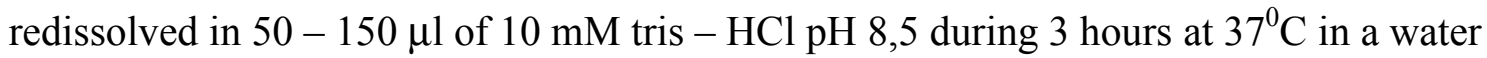
bath. The concentration of the DNA was determined at OD $260 \mathrm{~nm}$ and $15 \mu \mathrm{g}$ were used for a restriction digestion.

\title{
3.2.2.7 DNA isolation from mouse tail biopsy
}

\author{
Proteinase K solution $\quad 10 \mathrm{mg} / \mathrm{ml}$ in NET - \\ buffer, store at $-20^{\circ} \mathrm{C}$
}

Fresh $1 \mathrm{~cm}$ pieces of mouse tails were put each into a 1,5 ml eppendorf tube, $500 \mu \mathrm{lof}$ NET-buffer were added and vortexed. $50 \mu \mathrm{l}$ of proteinase $\mathrm{K}$ solution were added and vortexed, then $50 \mu 1$ of $10 \%$ SDS were added and vortexed again. The mixture was incubated with vigorous shaking at $56^{\circ} \mathrm{C}$ overnight. Hairs and other insoluble rests were spun down for 5 minutes at $13000 \mathrm{rpm}$ and the supernatant transferred into a new tube. DNA was precipitated upon addition of $500 \mu \mathrm{l}$ of isopropanol. The DNA pellet was fished out with a glass hook molten from a pasteur pipette, washed twice with $70 \%$ ethanol and air - dried for 15 minutes. The pellet was dissolved in $100 \mu \mathrm{l}$ of $10 \mathrm{mM}$ Tris $-\mathrm{HCl} \mathrm{pH} 8,5$ during 20 minutes and $1 \mu 1$ or $0,6 \mu 1$ used for PCR.

\subsubsection{Agarose gel electrophoresis for DNA separation}

For separation of DNA fragments of different length agarose gels were used. Suitable agarose concentration was chosen depending on the size of separating the DNA fragments: 


\begin{tabular}{|c|c|}
\hline $\begin{array}{c}\text { Concentration of } \\
\text { agarose }(\% \mathbf{w} / \mathbf{v})\end{array}$ & DNA size (kb) \\
\hline 0,7 & $20-1$ \\
\hline 1,0 & $7-0,5$ \\
\hline 1,5 & $4-0,2$ \\
\hline 2,0 & $3-0,1$ \\
\hline
\end{tabular}

\begin{tabular}{|l|l|}
\hline Sample buffer 6x: & for $50 \mathrm{ml}:$ \\
\hline $\begin{array}{l}0,15 \% \text { bromphenolblue } \\
0,15 \% \text { xylenecyanate FF }\end{array}$ & $75 \mathrm{mg}$ \\
$70 \%(\mathrm{mg} / \mathrm{v})$ Sucrose & $20 \mathrm{~g}$ \\
\hline
\end{tabular}

The necessary amount of agarose was boiled in $500 \mathrm{ml}$ of 1x TAE buffer (40 mM Tris $\mathrm{HCl}, 2 \mathrm{mM}$ EDTA, $\mathrm{pH} 8,0$ ) using a microwave oven and stored at $65^{\circ} \mathrm{C}$. For small analytical gels, $30 \mathrm{ml}$ (for small preparative gels, $50-60 \mathrm{ml}$ ) of agarose was put into a chamber for electrophoresis directly and chilled at RT till the gel was solidified. The chamber was then filled with 1x TAE buffer, DNA probes were mixed with sample buffer (end concentration 1x) and put into gel pockets. The left gel pocket was always filled with $10 \mu 1$ of $1 \mathrm{~kb}$ - DNA - ladder as standard. After electrophoresis, the gel was soaked in ethidium bromide solution for $15-20$ minutes and pictures were taken. For big preparative gels, 200 - $400 \mathrm{ml}$ agarose were used for a gel. After boiling of the appropriate amount of agarose in $1 \mathrm{x}$ TAE buffer, the liquid was chilled till $55^{\circ} \mathrm{C}$, ethidium bromide was added (final concentration $0,5 \mu \mathrm{g} / \mathrm{ml}$ ) and put on a gel rack. The rack was immersed into a chamber for electrophoresis filled with 1x TAE. DNA probes were mixed with sample buffer (end concentration 1x) and put into gel pockets. The left gel pocket was always filled with $30 \mu \mathrm{l}$ of $1 \mathrm{~kb}$ - DNA - ladder. Electrophoresis was done at a voltage of 3 
$-4 \mathrm{~V} / \mathrm{cm}$. Due to intercalation of ethidium bromide, DNA fragments are visible as stripes under UV - light. Photo pictures of gels were taken together with a ruler for later adjustment of fragment lengths on southern blots.

\subsubsection{Extraction of DNA fragments from agarose gels}

The QIAEXII DNA extraction kit was used for extraction of DNA from agarose gels. All solutions and protocols were taken from QIAGEN - supplier. The desired DNA fragment was cut out from a gel under UV - light (hand lamp, $312 \mathrm{~nm}$ ) and weighted. For each 100 mg of gel $300 \mu 1$ of QX1-buffer were added and, in dependence on DNA amount, 10 - 30 $\mu 1$ of QIAEXII glass milk pipetted to a probe. The mixture was incubated 5 times for 2 minutes at $50^{\circ} \mathrm{C}$ with mixing each time to keep the glass milk in suspension. The glass milk was spun down for 30 seconds at $13000 \mathrm{rpm}$, resuspended in $500 \mu 1$ of QX1-buffer and centrifuged again. The supernatant was removed, the pellet was resuspended in $500 \mu \mathrm{l}$ of PE- buffer followed by a new centrifugation step. The liquid was completely removed with a pipette and the pellet was air-dried till it became white. The DNA was eluted in $20-$ $25 \mu \mathrm{l}$ of $10 \mathrm{mM}$ tris- $\mathrm{HCl} \mathrm{pH} 8,5$ during 5 minutes at RT or if the length of the DNA fragment was more then $3000 \mathrm{bp}$ at $50^{\circ} \mathrm{C}$. Elution efficiency was controlled on agarose gels.

\subsubsection{Transformation of E.coli via electroporation with plasmid DNA}

$40 \mu \mathrm{l}$ of competent E.coli (strain XL1 blue) cells frozen in 10\% sterile glycerol were thawed on ice, immediately mixed with $1,2 \mu$ DNA ligation mix and placed into an icecold sterile electoporation cuvette (Stratagene). Cells were transformed by an impulse of $1800 \mathrm{~V}$ at a constant capacitance of $10 \mu \mathrm{F}$. Immediately after electroporation cells were resuspended in $500 \mu \mathrm{l}$ of room temperature SOC medium, transferred into a sterile eppendorf tube and incubated for 30 minutes at $37^{\circ} \mathrm{C}$. Finally the whole suspension was put onto $10 \mathrm{~cm} \mathrm{LB} \mathrm{-} \mathrm{ampicilline} \mathrm{(or} \mathrm{kanamycine)} \mathrm{agar} \mathrm{plate,} \mathrm{distributed} \mathrm{homogeneously}$ with a spatula, dried for 10 minutes and the plate left overnight in an incubator at $37^{\circ} \mathrm{C}$. The colonies obtained were analysed by plasmid miniprep method. 


\subsubsection{Cryoconservation of E.coli clones using DMSO solution}

Positive E.coli transformants were plated from liquid culture onto LB - ampicilline (or kanamycine) agar plate using a wolfram loop and grown overnight at $37^{\circ} \mathrm{C}$. Obtained E.coli layer was harvested by a sterile toothpick, resuspended in $1 \mathrm{ml}$ of sterile $7 \%$ DMSO in water and immediately frozen at $-80^{\circ} \mathrm{C}$.

\subsubsection{DNA hybridisation techniques}

\subsubsection{DNA transfer to Hybond N membranes}

This method is famous as southern-blotting (Southern 1975; Alwine et al. 1977).

The presence of a fragment of interest in a mixture of DNA fragments after enzymatic restriction digestion was determined using southern blotting followed by DNA hybridisation.

\begin{tabular}{|l|l|}
\hline Denaturation solution & \multicolumn{1}{|c|}{$\begin{array}{c}1,5 \mathrm{M} \mathrm{NaCl} \\
0,5 \mathrm{M} \mathrm{NaOH}\end{array}$} \\
\hline \multirow{3}{*}{ Neutralisation solution } & $\begin{array}{l}1,5 \mathrm{M} \mathrm{NaCl} \\
0,5 \mathrm{M} \text { tris- } \mathrm{HCl}, \mathrm{pH} 7,2 \\
1 \mathrm{mM} \text { EDTA }\end{array}$ \\
\hline Transfer buffer & $\begin{array}{l}3 \mathrm{M} \mathrm{NaCl} \\
\text { (20x SSC) }\end{array}$ \\
\hline
\end{tabular}

DNA after electrophoresis was denatured in the gel. To do that, the gel was incubated in the denaturation solution (a volume was taken so that the gel was completely immersed in it) twice for 15 minutes. Neutralisation was done twice for 15 minutes in the appropriate solution and the gel was then equilibrated for 20 minutes in 20x SSC. After these preincubation steps the capillary transfer were assembled as indicated in figure 6 . 


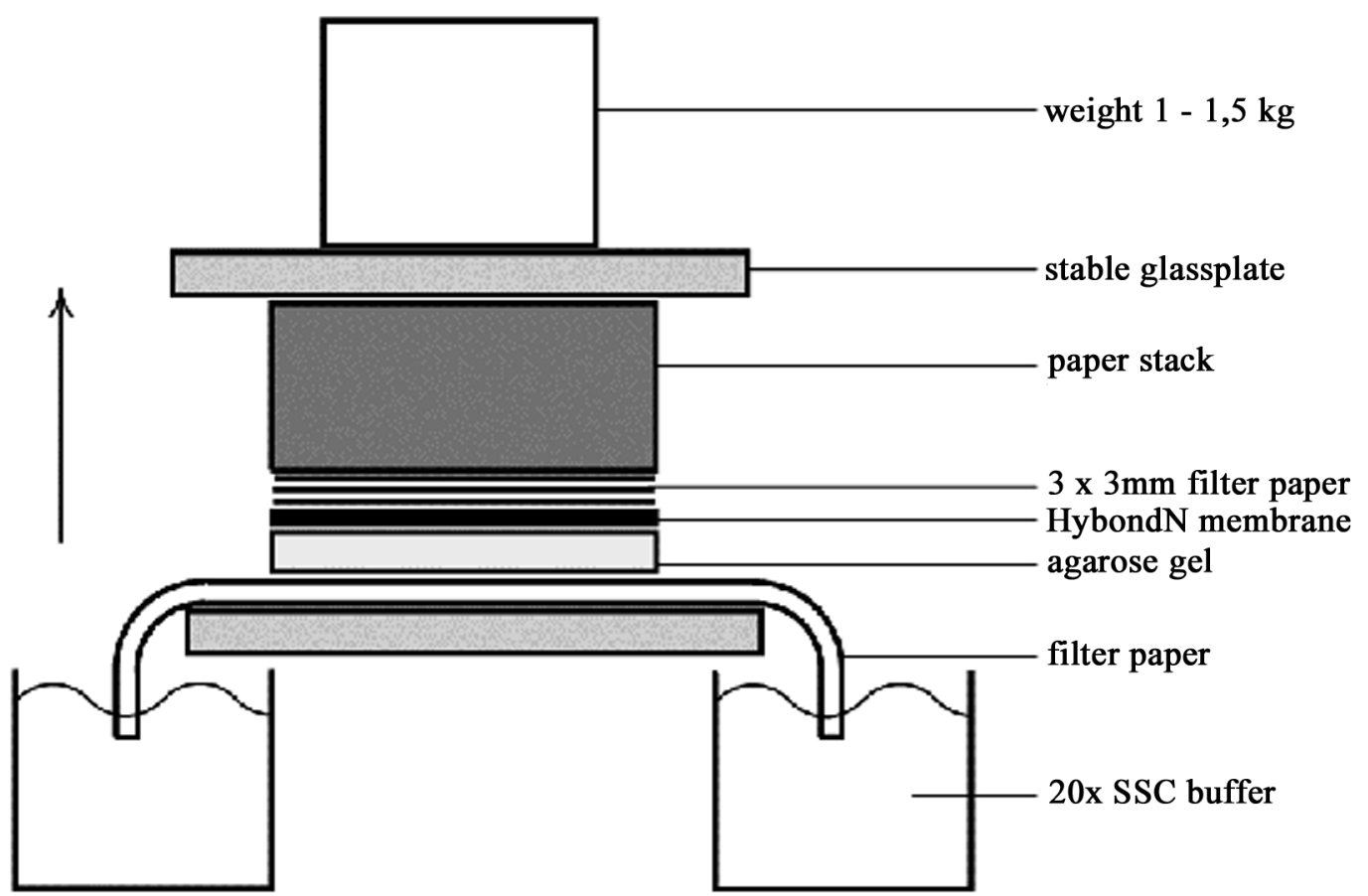

Figure 6: A schema of capillary transfer of DNA to nylon membrane (southern blotting)

A nylon (HybondN) membrane was soaked for 3 minutes in $\mathrm{dd}_{2} \mathrm{O}$ and then for 10 minutes in 20x SSC before placing it onto a gel. An arrow shows the direction of liquid movement, which transfers DNA from agarose onto membrane. The transfer was always done overnight (16-24 hours). Then the membrane was air-dried for $1-2$ hours and the DNA cross-linked to the membrane with UV light (15-30 seconds on the transilluminator).

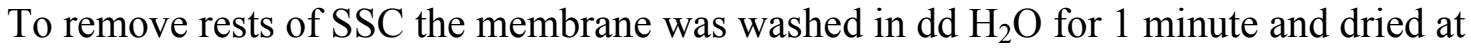
$65^{\circ} \mathrm{C}$ for at least 30 minutes.

\subsubsection{DNA labelling with $\alpha-\left[{ }^{32} P\right]-$ dCTP (making of DNA probes)}

This method is adopted from Feinberg and Vogelstein (Feinberg and Vogelstein 1983). A random priming procedure was used to get radioactive single stranded DNA of the desired sequence (a probe). Rediprime ${ }^{\mathrm{TM}}$ II DNA labelling kit (Amersham Pharmacia Biotech) was used for that. 
Denaturation of DNA: approximately $25 \mathrm{ng}$ of DNA fragment were mixed in $45-47,5$ $\mu 1 \mathrm{H}_{2} \mathrm{O}$ (HPLC), denatured for 5 minutes at $95^{\circ} \mathrm{C}$ and centrifuged shortly

Labelling:

$45-47,5 \mu 1$ of denatured DNA

1 tube of labelling pre-mix (contains dATP, dGTP, dTTP, Klenow-fragment of DNA polymeraseI, random primers) $50-25 \mu \mathrm{Ci} \alpha-\left[{ }^{32} \mathrm{P}\right]-\mathrm{dCTP}$ (Redivue, Amersham) were mixed together and incubated at $37^{\circ} \mathrm{C}$ for 15 minutes After that the reaction was stopped upon addition of $150 \mu \mathrm{TE}$ buffer and kept on ice till further usage.

For separation of non-incorporated $\alpha-\left[{ }^{32} \mathrm{P}\right]-\mathrm{dCTP}$ the reaction volume was gel filtered on a Sephadex ${ }^{\circledR} G 50$ column (see under 3.2 .1 .4 ). The incorporated radioactivity in the flow through was counted according to the Cerenkov procedure (Berger 1984) in a ß-counter. The percentage of incorporated radioactivity was calculated from the fact that $50 \mu \mathrm{Ci}$ corresponds to $111 \times 10^{6} \mathrm{cpm}$ (Cooper 1981). Specific radioactivity usually was $10^{9}$ $\mathrm{cpm} / \mu \mathrm{g}$ DNA.

The following probes were used for $\lambda$-phage mouse genomic library screenings and for genotyping of embryonic stem cell transformants:

\section{mVti1a:}

$\lambda$-phage library

"probe 237"

contained 100bp upstream from ATG codon and 60bp downstream from stop codon from pT7T3D- Pac (AA016379) were cut out with XhoI + NotI; contains 900 bp mVtila cDNA sequence "EST probe" contained 100bp 5 untranslating region, first exon and $750 \mathrm{bp}$ intron sequence of Vti1a; cut out from pT7T3D (AA097517) with XhoI/NotI 
ES cell clones

NdeI screening

"pVA45 derived probe"

900 bp from pVA45 were cut out by XbaI + EcoRI

XbaI screening

"pVA42 derived probe"

1300 bp from pVA42 were cut out by XbaI + EcoRI

mVti1b:

$\lambda$-phage library

"probe 235 "

Nothern blot

$1000 \mathrm{bp}$ from pCMV - SPORT2 (AA105524) were cut out by

SalI + NotI; contains mVtilb cDNA sequence

ES cell clones

EcoRI screening

"EcoRI 400bp probe"

400 bp from pVA12 were cut out by EcoRI

XbaI screening

"XbaI PCR probe"

$490 \mathrm{bp}$ were PCR amplified with using of primer 1

(CCATGEATTGTCACTGTCC, pos 3598 - 3616) and primer

2 (CATGTATAACATTAATAGCTTG, pos 4069 - 4089) on

pVA7 template

\subsubsection{Screening of phage $\lambda$ mouse genomic DNA libraries}

\section{Preparation of host bacteria}

E.coli strain LE392 was grown ON in LB medium as host bacteria (see 3.1.15). $10 \mathrm{ml}$ of stationary culture were diluted 1:10 with the same medium and the bacteria were grown to an $\mathrm{OD}_{600}$ of $0,5-0,8$. The bacteria were pelleted for $10 \mathrm{~min}$ at $2800 \mathrm{rpm}$ and resuspended in $50 \mathrm{ml}$ of $10 \mathrm{mM} \mathrm{MgSO}_{4}$. Obtained bacterial suspension was incubated for $1 \mathrm{~h}$ at $37^{\circ} \mathrm{C}$ with rotation and then kept at $4^{0} \mathrm{C}$ till use.

\section{Plating of the library}

The prepared bacteria were incubated with phage library diluted in SM-buffer (see 3.1.15)

1:1000. The amount of bacteria and phage solution for infection was always tested experimentally on one small plate before plating of large number of plates. For optimal was taken the amount of phage suspension added resulting in total lysis of the bacteria on plates. In our case $1 \mathrm{ml}$ of prepared bacteria was infected with $40 \mu \mathrm{l}$ of phage suspension and left standing without shaking at $37^{\circ} \mathrm{C}$ for $20 \mathrm{~min}$. After that $14 \mathrm{ml}$ of top-agarose (see 3.1 .15 ) of $60^{\circ} \mathrm{C}$ were added and immediately poured onto $15 \mathrm{~cm}$ agar-plate (see 3.1.15). Plates were dried opened for $20 \mathrm{~min}$ in a sterile hood and incubated upside down at $37^{\circ} \mathrm{C}$ for about $6 \mathrm{~h}$ till plaques were visible. Afterwards "lysed" plates were kept at $4^{0} \mathrm{C}$ to increase solidity of the top-agarose for making of filter replicas. 


\section{Generating HybondN replica filters}

\begin{tabular}{|c|c|}
\hline Denaturation solution & $\begin{array}{l}1,5 \mathrm{M} \mathrm{NaCl} \\
0,5 \mathrm{M} \mathrm{NaOH}\end{array}$ \\
\hline Neutralisation solution & $\begin{array}{l}0,5 \mathrm{M} \mathrm{NaCl} \\
1 \mathrm{M} \text { tris-HCl, pH 7,2 } \\
1 \mathrm{mM} \text { EDTA }\end{array}$ \\
\hline $\begin{array}{l}\text { Equilibration solution } \\
\text { ( } 2 \mathrm{x} \text { SSC) }\end{array}$ & $\begin{array}{l}0,3 \mathrm{M} \mathrm{NaCl} \\
0,03 \mathrm{M} \text { trisodium } \\
\text { citrate, } \mathrm{pH} 7,0\end{array}$ \\
\hline
\end{tabular}

A HybondN filter was placed onto the cooled top of the plate lysed by phage and left there for $30 \mathrm{sec}$. The plate and filter were marked with pencil and 5 holes (through the filter and agar) during that time for orientation of the filter later. A second filter was put onto the same plate for $1 \mathrm{~min}$ and the procedure was repeated completely. Filters were put upside down onto filter paper soaked with denaturation solution for $5 \mathrm{~min}$. Then filters were placed with DNA facing up for 2x10 min on filter paper soaked with neutralisation solution. Filters were submerged for about $5 \mathrm{~min}$ in a tray filled with $2 \mathrm{x}$ SSC solution and then air-dried for about $2 \mathrm{~h}$. To cross-link the DNA, filters were put onto a clean UVtransilluminator and exposed to UV light for $15 \mathrm{sec}$. Fully treated filters were dried at $60^{\circ} \mathrm{C}$ for $30 \mathrm{~min}$ and used for DNA hybridisation with an appropriate probe (see 3.2.7.2 and 3.2.7.4).

\subsubsection{Hybridisation of HybondN membranes with radioactive labelled DNA probes (Amersham procedure)}

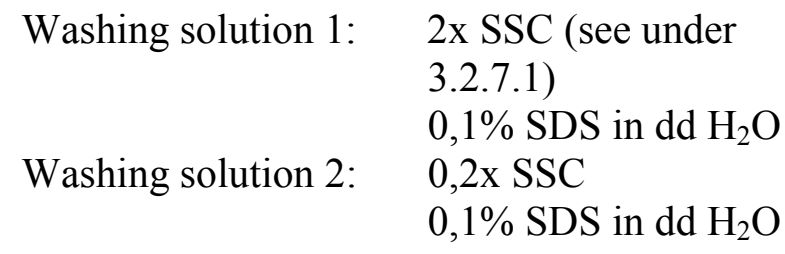

Rapid hyb buffer was heated at $65^{\circ} \mathrm{C}$ for at least 30 minutes in a hybridisation oven. Before hybridisation DNA blots were pre-incubated in 5-15 $\mathrm{ml}$ of hot Rapid hyb buffer (Amersham Pharmacia Biotech) for 30 minutes at $65^{\circ} \mathrm{C}$. The labelled DNA probe was denatured for 7 minutes at $95^{\circ} \mathrm{C}$, chilled on ice for 1 minute, pipetted directly into the buffer and mixed. For every $5 \mathrm{ml}$ of buffer, $25 \%$ of the labelled probe was taken (see under 3.2.7.2). The blot was incubated in the hybridisation oven overnight with slow rotation at 
$65^{\circ} \mathrm{C}$. The blot was washed once for 20 minutes at RT in solution 1 and twice for 15 minutes at $65^{\circ} \mathrm{C}$ in solution 2 (water bath). The efficiency of washing was controlled with a hand monitor and at the end was $35-45$ desintegrations per second. The membrane was then sealed between plastic sheets to prevent its drying and exposed to a phosphoimager screen for $5-24$ hours

In the present work murine cellular and mouse DNA were analysed to determine genotypes for $\mathrm{mVtil} b$ and $\mathrm{mVtila}$ by hybridisation technique indicated above. Structures of wild type and homologous recombinated loci and sequences of the chosen probes can be viewed in chapter "Results". The expected fragments sizes for wild type and null-allele are indicated in table 1:

Table 1: Size of restriction fragments upon genotype analysis of ES cell transformants of $\mathbf{m V t i 1 b}$ and mVti1a gene targeting

\begin{tabular}{|l|c|c|c|c|}
\hline & $\begin{array}{c}\text { mVtilb } \\
\text { gene }\end{array}$ & $\begin{array}{c}\text { mVti1b } \\
\text { gene }\end{array}$ & $\begin{array}{c}\text { mVtila } \\
\text { gene }\end{array}$ & $\begin{array}{c}\text { mVti1a } \\
\text { gene }\end{array}$ \\
\hline Digestion with & EcoRI & XbaI & NdeI & XbaI \\
\hline Wild type allele & $4,0 \mathrm{~kb}$ & 8,0 & $4,0 \mathrm{~kb}$ & $6,0 \mathrm{~kb}$ \\
\hline Null allele & $4,8 \mathrm{~kb}$ & 7,0 & $5,0 \mathrm{~kb}$ & $4,0 \mathrm{~kb}$ \\
\hline
\end{tabular}

\subsubsection{PCR method for DNA amplification}

(adopted from Saiki et al. (Saiki et al. 1986; Saiki et al. 1988))

The polymerase chain reaction (PCR) is a method for amplification of certain fragments of DNA. The method was used for generation of DNA probes (see under 3.2.7.2) and for clarification of mice genotypes on certain loci.

The PCR is based on 3 steps, which are necessary for every DNA synthesis:

1.Template DNA denaturation to get single stranded DNA.

2.Annealing (binding of oligonucleotide primers to single strands).

3.Extension (synthesis of DNA, starting from bound primers) 


\begin{tabular}{|l|l|}
\hline 10x PCR-dNTP-mix: & $25 \mathrm{mM}$ of every dATP, dCTP, dGTP, dTTP in dd $\mathrm{H}_{2} \mathrm{O}$ \\
\hline $10 \mathrm{x}$ reaction buffer & $500 \mathrm{mM} \mathrm{KCl}$ \\
& $100 \mathrm{mM}$ tris- $\mathrm{HCl} \mathrm{pH} 9,0$ \\
\hline Oligonucleotide primer 1 & $2 \mathrm{pmol} / \mu \mathrm{l}$ \\
\hline Oligonucleotide primer 2 & $2 \mathrm{pmol} / \mu \mathrm{l}$ \\
\hline Taq DNA polymerase & $5 \mathrm{U} / \mu \mathrm{l}$ \\
\hline $\mathrm{MgCl}_{2}$ was added till end concentration of $1,25 \mathrm{mM}$ \\
\hline
\end{tabular}

Cycles (example):

$1.95^{\circ} \mathrm{C} \quad 40 \mathrm{sec}$

2. $50^{\circ} \mathrm{C} \quad 40 \mathrm{sec} \quad$ for certain oligos the temperature was increased or decreased

3. $72^{\circ} \mathrm{C} \quad 60 \mathrm{sec} \quad$ the time was increased or decreased if the length of amplified fragment was more or less then $1 \mathrm{~kb}$

Typical 30 cycles

\subsubsection{PCR on genomic DNA template for genotype analysis}

To elucidate genotypes of mice obtained from breeding"mVtilb clone114 mouse strain", two PCR series were applied using tail biopsy DNA (see under 3.2.2.7) as template.

To amplify $500 \mathrm{bp}$ of wild type or $1500 \mathrm{bp}$ of neo+ interrupted fragment of exon 123-180 of the mVtilb loci a PCR was done with the primers Seq5-Seq50.

Seq5-Seq50 PCR:

\begin{tabular}{|c|c|}
\hline dd $\mathrm{H}_{2} \mathrm{O}$ & $33,5 \mu 1$ \\
\hline 10x reaction buffer & $5 \mu \mathrm{l}$ \\
\hline dNTP & $5 \mu l$ \\
\hline $\mathrm{MgCl}_{2} 25 \mathrm{mM}$ & $2,5 \mu \mathrm{l}(1,5 \mathrm{mM})$ \\
\hline Oligonucleotide primer Seq 5 & $5 \operatorname{pmol}(1 \mu \mathrm{l})$ \\
\hline Oligonucleotide primer Seq 50 & 5 pmol $(1 \mu \mathrm{l})$ \\
\hline Genomic DNA & $1 \mu 1$ \\
\hline \multicolumn{2}{|c|}{$\begin{array}{l}\text { The mixture was heated at } 95^{\circ} \mathrm{C} \\
\text { for } 5 \text { minutes, then Taq polymerase was added }\end{array}$} \\
\hline Taq DNA polymerase & $1 \mu \mathrm{l}(5 \mathrm{U})$ \\
\hline
\end{tabular}

PCR reactions were done in a Thermocycler Master cycler gradient (Eppendorf) under the following conditions: 
$1.95^{0} \mathrm{C} \quad 40 \mathrm{sec}$

2. $52^{0} \mathrm{C} \quad 40 \mathrm{sec}$

3. $72^{0} \mathrm{C} \quad 50 \mathrm{sec}$

Total 30 cycles

$10 \mu 1$ were then loaded onto an analytical agarose gel to estimate the length of amplified fragments.

To detect the presence or absence of neo+ interrupting cassette a Neo PCR was applied (amplifies $374 \mathrm{bp}$ of neo+ cassette)

Neo PCR:

\begin{tabular}{|l|l|}
\hline $\mathrm{dd} \mathrm{H}_{2} \mathrm{O}$ & $13,8 \mu \mathrm{l}$ \\
\hline $10 \mathrm{x}$ reaction buffer & $2 \mu \mathrm{l}$ \\
\hline $\mathrm{dNTP}$ & $0,4 \mu \mathrm{l}$ \\
\hline $\mathrm{MgCl}_{2} 25 \mathrm{mM}$ & $1 \mu \mathrm{l}(1,5 \mathrm{mM})$ \\
\hline Oligonucleotide primer AK30 & $5 \mathrm{pmol}(1 \mu \mathrm{l})$ \\
\hline Oligonucleotide primer AK31 & $5 \mathrm{pmol}(1 \mu \mathrm{l})$ \\
\hline Genomic DNA & $0,6 \mu \mathrm{l}$ \\
\hline Taq DNA polymerase & $0,2 \mu \mathrm{l}(1 \mathrm{U})$ \\
\hline
\end{tabular}

PCR reactions were done in GeneAmp9600 (Perkin Elmer) under following conditions:

$1.96^{\circ} \mathrm{C} \quad 15 \mathrm{sec}$

2. $58^{0} \mathrm{C} \quad 30 \mathrm{sec}$

3. $72^{0} \mathrm{C} \quad 40 \mathrm{sec}$

Total 30 cycles

For analysis $10 \mu \mathrm{l}$ were then loaded onto an analytical agarose gel.

\subsubsection{Methods of working with RNA}

\subsubsection{RNA extraction from mouse tissues}

RNeasy ${ }^{\circledR}$ protect mini kit (see 3.1.6) was used to extract RNA from mouse liver, brain, kidney and spleen. The whole procedure was done according to the manual supplied. Briefly $20 \mathrm{mg}$ of each tissue was cut into a pre-weighted tube and immersed in $300 \mu \mathrm{l}$ of RNAprotect buffer. The tissue sample was then cut into small (several millimetres) pieces 
and left at $4^{0} \mathrm{C}$ till use. The tissue sample was then transferred into $350 \mu 1$ of lysis buffer RLT and the sample homogenised using Ultra-Turrax. The obtained homogenate was centrifuged for $3 \mathrm{~min}$ at maximal speed and $350 \mu \mathrm{l}$ of $70 \%$ ethanol were added to the supernatant. The obtained mixture was loaded onto a RNeasy column sitting in a $2 \mathrm{ml}$ collection tube, centrifuged for $15 \mathrm{sec}$ at $10000 \mathrm{rpm}$ and the flow-through was discarded. $700 \mu 1$ of RW1 buffer were pipetted onto a column and centrifuged again with the same conditions. The column was placed into a new collection tube and loaded with $500 \mu 1$ of RPE buffer followed by a new centrifugation for $15 \mathrm{sec}$ at $10000 \mathrm{rpm}$. That step was repeated once again with a centrifugation for $2 \mathrm{~min}$. The column was placed into a 1,5 $\mathrm{ml}$ collection tube and the RNA was eluted in $2 \times 40 \mu l$ of RNAse-free water for $1 \mathrm{~min}$ at RT with centrifugation for $1 \mathrm{~min}$ at $10000 \mathrm{rpm}$. The concentration was determined at $\mathrm{OD}=260$ nm. One $\mathrm{OD}_{260}$ corresponds $40 \mu \mathrm{g} / \mathrm{ml}$ RNA. The RNA samples were kept frozen at $-80^{\circ} \mathrm{C}$ till use.

\subsubsection{Agarose gel electrophoresis for RNA separation and nothern blotting}

\begin{tabular}{|l|l|}
\hline $\begin{array}{l}\text { Diethylpyrocarbonate (DEPC) - } \\
\mathrm{H}_{2} \mathrm{O}:\end{array}$ & $\begin{array}{l}\text { 2,5 } \mathrm{L} \text { dd } \mathrm{H}_{2} \mathrm{O} \text { were mixed with } 25 \mathrm{ml} \text { of DEPC in a } \\
\text { glass bottle at } 37^{\circ} \mathrm{C} \text { with rotation } \mathrm{ON} \text {. The mixture } \\
\text { was then autoclaved to destroy DEPC. }\end{array}$ \\
\hline $\begin{array}{l}\text { 10x buffer for RNA } \\
\text { electrophoresis: }\end{array}$ & $\begin{array}{l}200 \mathrm{mM} \text { MOPS } \\
50 \mathrm{mM} \text { Sodium acetate } \\
10 \mathrm{mM} \text { EDTA } \\
\text { in DEPC - } \mathrm{H}_{2} \mathrm{O}\end{array}$ \\
\hline $2 \%$ agarose gel for RNA & $10 \mathrm{ml} 10 \mathrm{x}$ buffer \\
separation: & adjust volume till $100 \mathrm{ml}$ with $\mathrm{DEPC}-\mathrm{H}_{2} \mathrm{O}$, \\
& boil in microwave oven and chill to approx. $60^{0} \mathrm{C}$, \\
& then add: \\
& 1,66 ml formaldehyde \\
& $15 \mu$ lethydiumbromide \\
\hline Sample-buffer: & 1 volume part of bromphenolblue \\
& 4 volume parts of DEPC - $\mathrm{H}_{2} \mathrm{O}$ \\
& 4 volume parts of formamide \\
& 2 volume parts of formaldehyde \\
& 2 volume parts of MOPS $10 \mathrm{x}$ buffer \\
\hline
\end{tabular}

Glass beakers, measuring cylinders and chamber for electrophoresis were soaked in $1 \mathrm{M}$ $\mathrm{NaOH}$ for $2 \mathrm{~h}$ at RT to eliminate any RNAse activity. All stuff treated by $\mathrm{NaOH}$ was then rinsed several times with $\mathrm{dd}_{2} \mathrm{O}$ and air dried. A gel was prepared as indicated above and 
covered with 1x buffer for electrophoresis. DEPC-water was used for dilution of the buffer in $\mathrm{NaOH}$ treated glass beaker. Each pocket of the gel was loaded with $10 \mu \mathrm{g}$ RNA in sample buffer. Electrophoresis was done in a small chamber at a voltage of $3-4 \mathrm{~V} / \mathrm{cm}$. After electrophoresis the gel was put into a tray with 20x SSC for 20 min for equilibration and RNA was transferred onto HybondN membrane (nothern blot) as shown for DNA under 3.2.7.1, figure 6 .

\subsubsection{Hybridisation of Nothern blots}

\begin{tabular}{|c|c|}
\hline Hybridisation solution: & $\begin{array}{l}\text { 72ml Formamide } \\
\text { 36ml 20x SSC } \\
\text { 1,5ml Tris- } \mathrm{HCl} 1 \mathrm{M}, \mathrm{pH}=7,5 \\
\text { 1,5g SDS } \\
\text { 3ml Denhardt solution } 50 \mathrm{x} \\
\text { 30ml 50\% dextransulfate (Pharmacia) }\end{array}$ \\
\hline \multicolumn{2}{|c|}{$\begin{array}{l}15 \mathrm{~g} \text { dextransulfate were filled with } \mathrm{ddH}_{2} \mathrm{O} \text { till } 30 \mathrm{ml} \text { and dissolved at } 80^{\circ} \mathrm{C} \text {; } \\
\text { subsequently all other components were added and the volume was adjusted till } \\
150 \mathrm{ml} \text { with } \mathrm{ddH}_{2} \mathrm{O} \text {. The mixture was then incubated overnight at RT on a } \\
\text { rocker with weak agitation and stored at } 4^{0} \mathrm{C} \text {. }\end{array}$} \\
\hline
\end{tabular}

\begin{tabular}{|l|l|}
\hline $\begin{array}{l}\text { For Vtilb mRNA blot the } \\
\text { "probe 235" was used }\end{array}$ & $\begin{array}{l}\text { 1000bp from pCMV-SPORT2 (AA105524) were } \\
\text { cut out by SalI + NotI; contains mVtilb cDNA } \\
\text { sequence }\end{array}$ \\
\hline $\begin{array}{l}\text { For syntaxin 8 mRNA blot } \\
\text { following probe was used: }\end{array}$ & $\begin{array}{l}\text { 600bp from pBK } 45 \text { were cut out by BamHI and } \\
\text { EcoRI; contains cDNA of the syntaxin 8 soluble } \\
\text { domain, encoding amino acids 1-213 (Antonin et } \\
\text { al. 2000a); cDNA was amplified from lung } \\
\text { cDNA library }\end{array}$ \\
\hline
\end{tabular}

\begin{tabular}{|l|l|}
\hline Washing solution 1: & 2x SSC (see under \\
& 3.2 .7 .1 ) \\
& $0,1 \%$ SDS in $\mathrm{dd}_{2} \mathrm{O}$ \\
\hline Washing solution 2: & $0,2 \mathrm{SSC}$ \\
& $0,1 \%$ SDS in $\mathrm{dd}_{2} \mathrm{O}$ \\
\hline
\end{tabular}

\section{The syntaxin 8 mRNA detection}

The hybridisation buffer was heated at $42^{\circ} \mathrm{C}$ for at least 30 minutes in a hybridisation oven. Before hybridisation RNA blots were pre-incubated in $5 \mathrm{ml}$ of hot hybridisation buffer for 30 minutes at $42^{\circ} \mathrm{C}$. The labelled DNA probe was denatured for 7 minutes at $95^{\circ} \mathrm{C}$, chilled on ice for 1 minute, pipetted directly into the buffer and mixed. For every $5 \mathrm{ml}$ of buffer, $25 \%$ of the labelled probe was taken (see under 3.2.7.2). The blot was incubated in the 
hybridisation oven overnight with slow rotation at $42^{\circ} \mathrm{C}$. The blot was washed once for 20 minutes at RT in solution 1 and once for 30 minutes at $55^{\circ} \mathrm{C}$ in solution 2 (water bath). The efficiency of washing was controlled with a hand monitor and at the end was $35-45$ desintegrations per minute. The membrane was then sealed between plastic sheets to prevent its drying and exposed to a phosphoimager screen for $5-24$ hours.

\section{Vti1b mRNA detection}

The procedure for Southern blot hybridisation in the RapidHyb ${ }^{\circledR}$ buffer (Amersham, Braunschweig) was applied as described under 3.2.7.4, without any modifications. 


\subsection{Methods of cell biology and biochemistry}

\subsubsection{Methods for handling of eucaryotic cells}

Cells were cultivated in water-saturated atmosphere under $5 \% \mathrm{CO}_{2}$ at $37^{0} \mathrm{C}$. If not otherwise indicated, all media were pre-warmed till $37^{\circ} \mathrm{C}$. In general cultivation was done in following media:

$$
\mathrm{DMEM}+10 \% \mathrm{FKS}+1 \mathrm{x} \text { penicillin/streptomycin }
$$

Media for transfected embryonic stem cells contained additionally $335 \mu \mathrm{g} / \mathrm{ml}$ of Gentamycine $418 \circledR$

\subsubsection{Trypsination of cells}

$\begin{array}{ll}\text { Trypsin - EDTA solution: } & 0,05 \%(\mathrm{w} / \mathrm{v}) \text { Trypsin } \\ & 0,02 \%(\mathrm{w} / \mathrm{v}) \text { EDTA in modified Puck's } \\ & \text { salt solution }\end{array}$

Passaging of cells was done regularly after they reached confluence. To do that medium was sucked off using a peristaltic pump and the cells were washed once with PBS. After PBS was removed by the same way, cells were incubated with trypsin - EDTA solution for about 5 minutes at $37^{0} \mathrm{C}$ till their attachment to each other and the culture dish was lost. The reaction was stopped by addition of serum - rich medium and cells were resuspended with pipette up and down several times till single cell suspension was obtained. Cells were counted in a Neubauer - chamber. Cells were then plated in desiraed amounts per plate or pelleted (1000 rpm, $5 \mathrm{~min}$, Labofuge) for cryoconservation.

\subsubsection{Cryoconservation of cells}

Cryo - medium:

$10 \%(\mathrm{v} / \mathrm{v}) \mathrm{DMSO}$ in corresponding cell culture medium

Cells were trypsinated, resuspended in medium, pelleted (1000 rpm, 5 min, Labofuge). After the supernatant was removed, cells were resuspended in $1 \mathrm{ml}$ ice - cold cryo medium and transferred into a marked cryotube. The cryotube was immediately placed into a freezer $\left(-80^{\circ} \mathrm{C}\right)$ and transferred by the next day into liquid nitrogen for storage. 


\subsubsection{Thawing and revitalising of cells}

After taking a cryotube from liquid - nitrogen storage it was incubated at RT for about 1 min. The tube was thawed in $70 \%$ ethanol at $37^{\circ} \mathrm{C}$ till only a small piece of ice was seen inside. The cell suspension was transferred into a tube with $9 \mathrm{ml}$ of ice - cold medium using an aseptic pasteur pipette and the cell pellet were sedimented (1000 rpm, $5 \mathrm{~min}, \mathrm{RT}$, Labofuge). The supernatant was removed and the cells were resuspended in $5 \mathrm{ml}$ of medium $\left(37^{0} \mathrm{C}\right)$ and transferred into a cell culture flask or plate. The medium was changed the next day to remove rests of DMSO, dead cells and cell debris.

\subsubsection{Isolation of hepatocytes}

A collagenase independent method was applied for preparation of hepatocytes (Meredith 1988). The disintegration of liver tissue is based on disintegration $\mathrm{Ca}^{2+}$ dependent cell-cell contacts through $\mathrm{Ca}^{2+}$ depletion.

\begin{tabular}{|c|c|}
\hline \multicolumn{2}{|c|}{ Solutions and buffers for isolation of hepatocytes } \\
\hline Anesthetic mixture of drugs: & $\begin{array}{l}1 \mathrm{ml} \mathrm{Ketavet}{ }^{\circledR}(\text { Parke Davis; } 100 \mathrm{mg} / \mathrm{ml}) \\
\left.1 \mathrm{ml} \text { Rompun }{ }^{\circledR} \text { (Bayer; } 20 \mathrm{mg} / \mathrm{ml}\right) \\
8 \mathrm{ml} 0,9 \% \mathrm{NaCl} \text { water solution } \\
\text { were mixed and sterile filtered }\end{array}$ \\
\hline 10x perfusion stock solution: & $\begin{array}{l}1400 \mathrm{mM} \mathrm{NaCl} \\
50 \mathrm{mM} \mathrm{KCl} \\
8 \mathrm{mM} \mathrm{MgCl}_{2} \times 2 \mathrm{H}_{2} \mathrm{O} \\
16 \mathrm{mM} \mathrm{Na}_{2} \mathrm{HPO}_{4} \times 2 \mathrm{H}_{2} \mathrm{O} \\
4 \mathrm{mM} \mathrm{K}_{2} \mathrm{HPO}_{4} \\
\text { Resulting pH of the solution is } 7,4 . \text { The solution } \\
\text { was sterile filtered }\end{array}$ \\
\hline Perfusion buffer: & $\begin{array}{l}\text { 1x perfusion stock solution } \\
25 \mathrm{mM} \text { NaHCO} \\
1 \mathrm{mM} \text { EDTA } \\
15 \mathrm{mM} \text { D-glucose } \mathrm{x} \mathrm{H}_{2} \mathrm{O} \\
2 \mathrm{mM} \text { DL-lactate } \\
0,2 \mathrm{mM} \text { Na-pyruvate } \\
\text { The solution was always prepared fresh, sterile } \\
\text { filtered and equilibrated with carbogen }\left(95 \% \mathrm{O}_{2} /\right. \\
\left.5 \% \mathrm{CO}_{2}\right) \text { for at least } 20 \text { minutes before usage, so } \\
\text { that the resulting pH of the solution was } 7,4 \text {. }\end{array}$ \\
\hline Wash buffer: & $\begin{array}{l}1 \mathrm{x} \text { perfusion stock solution } \\
1 \mathrm{mM} \mathrm{CaCl} \\
\text { The solution was sterile filtered and kept at room } \\
\text { temperature }\end{array}$ \\
\hline
\end{tabular}




\begin{tabular}{|l|l|}
\hline $\begin{array}{l}\text { Percoll }{ }^{\circledR} \text { gradient centrifugation } \\
\text { medium }\end{array}$ & $13,9 \mathrm{ml}$ Percoll \\
\hline Gelatine solution & 1g gelatine in $100 \mathrm{ml}$ PBS (1\%) was autoclaved and \\
& diluted with sterile PBS 1:10 (final concentration \\
& $0,1 \%)$ \\
\hline
\end{tabular}

\section{Gelatine treatment of coverslips and $3 \mathrm{~cm}$ plates}

$0,5 \mathrm{ml}$ or $1 \mathrm{ml}$ of gelatine solution in PBS (see above) were put onto sterile coverslips or 3 $\mathrm{cm}$ plates and left overnight in an incubator at $37^{\circ} \mathrm{C}$. Before using, the gelatine solution was removed and the surface was washed twice with sterile PBS. Coverslips and plates were left closed in the incubator till use.

\section{In situ perfusion of mouse liver and generation of a hepatocyte suspension:} (modified from Seglen P.O.(Seglen 1976))

A mouse was anesthetised by injection of $8,6 \mu$ of narcotic solution per gram of body weight intraperitoneal. An abdominal cavity was opened along of linea alba, the liver with the vena portae was exposed by the displacement of the abdominal contents to the right (see figure 7). A ligature was placed around of vena portae to fix it on the catheter later (a 2 in figure 7). The catheter was inserted into the vena portae and pushed till a little bit before the porta of the liver and then fixed. After the catheter was filled with blood coming out, the pre-warmed and $\mathrm{CO}_{2}$ equilibrated perfusion buffer was injected into the liver. The vena cava inferior must be cut immediately (a 1 in figure 7) to lower the pressure. The liver was perfused for 20 minutes at flow rate of $10 \mathrm{ml} /$ minute using a peristaltic pump (Pharmacia).

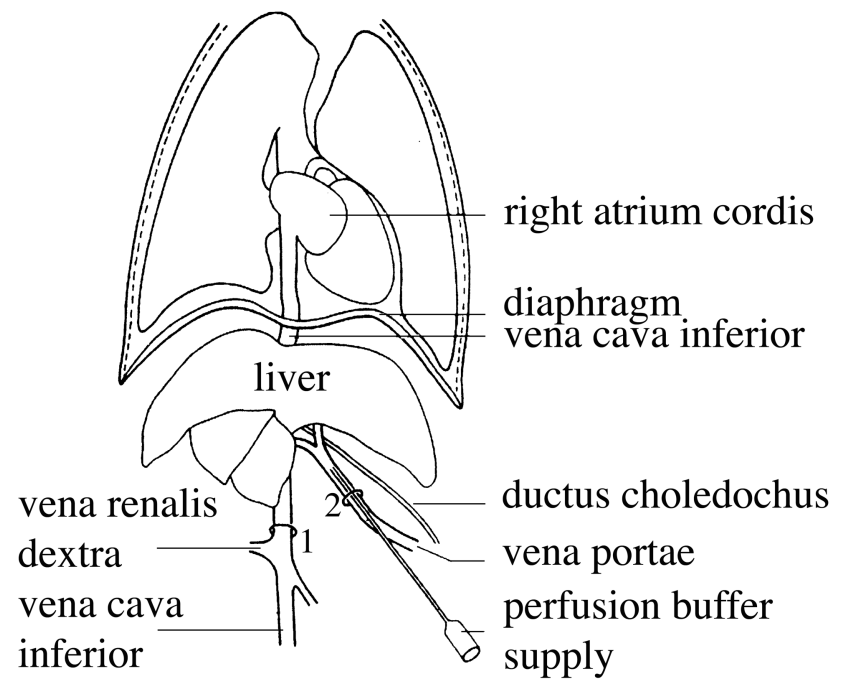

Figure 7: Schema of in situ liver perfusion 
After completion of the perfusion, the liver was cut out carefully, without any damage to the liver capsule, and transferred into a $10 \mathrm{~cm}$ petri dish. About $25 \mathrm{ml}$ of warm $\left(37^{0} \mathrm{C}\right)$ washing solution was added and all connective tissue, and the gallbladder were removed. The liver capsule was destroyed using tweezers and nearly all cells were brought into suspension. The suspension was filtered through aseptic cotton gauze to remove the rest of the connective tissue. The suspension was centrifuged 5 minutes at $600 \mathrm{rpm}$ for removal of non-parenchymal liver cells (kupffer-cells, ito-cells, endothelial cells). The obtained cell pellet was resuspended in $8 \mathrm{ml}$ washing buffer and intact hepatocytes were fractionated through Percoll® density gradient.

\section{Fractionation of hepatocytes via Percoll@ density gradient:}

To enrich vital hepatocytes in the cell pellet, the cell suspension described above $(8 \mathrm{ml}$ in washing solution) was mixed with $16 \mathrm{ml}$ of warm $\left(37^{0} \mathrm{C}\right)$ Percoll ${ }^{\circledR}$ gradient centrifugation medium (final concentration of Percoll ${ }^{\circledR} 58 \%$ ) and centrifuged 5 minutes at $2800 \mathrm{rpm}$ in a Heraeus -Megafuge. Dead hepatocytes, debris and non-parenchymal cells concentrated of surface of the gradient were removed together with centrifugation medium using a peristaltic pump. The remaining cell pellet with vital hepatocytes was resuspended in RPMI $/ 10 \%$ FKS. Around $6,5 \times 10^{5}$ cells were plated onto gelatine treated $3 \mathrm{~cm}$ plate and $1,5 \times 10^{5}$ cells were put onto each coverslip. After $3-4$ hours of cultivation the medium was changed. Cells were left in culture overnight and used for experiments.

\subsubsection{Preparing of mouse embryonic fibroblasts (MEF)}

$$
\begin{array}{ll}
\text { Trypsin - EDTA solution: } & 0,25 \%(w / v) \text { Trypsin, GIBCO BRL, Eggenstein } \\
& 0,02 \%(w / v) \text { EDTA in modified Puck's salt } \\
& \text { solution }
\end{array}
$$

A pregnant female of F1 generation was killed at the day 15 th of pregnancy. The abdominal cavity was opened and the uterus was taken out. Embryos were released from the uterus into a petri dish with sterile PBS and washed. All next steps were done in aseptic environment. Heads and livers of embryos were removed. Heads of embryos were kept at $4^{0} \mathrm{C}$ to extract DNA from them later (genotyping via PCR). The rest of each embryo was cut into several pieces and put into a separate Erlenmeyer flask. Bottoms of the $25 \mathrm{ml}$ Erlenmeyer flasks were covered with sterile glass beads and $5 \mathrm{ml}$ of trypsin solution were put inside. The embryonic tissues were digested for $15 \mathrm{~min}$ at $37^{\circ} \mathrm{C}$ with vigorous shaking. 
The reaction was stopped with $25 \mathrm{ml}$ of medium and a cell suspension was obtained by pipetting the liquid up and down. Embryonic cells were pelleted in $50 \mathrm{ml}$ Falcon ${ }^{\circledR}$ tubes at RT for $5 \mathrm{~min}$ at $1000 \mathrm{rpm}$ in a Heraeus -Megafuge. Cell pellets were resuspended in $10 \mathrm{ml}$ medium and placed onto $10 \mathrm{~cm}$ culture plates for overnight cultivation. Medium was changed the next day and cultivation was proceed till cells reached confluence. Fibroblasts of the first passage were divided in 3 cryotubes and frozen (see 3.3.1.2). One part of cultivated fibroblasts was kept in culture for establishment of the stable cell line. Fibroblasts of passage 7 and older were used for the experiments.

\subsubsection{Methods of protein biochemistry}

\subsubsection{Preparing of tissue - and cell homogenates for enzymatic assays and western - blot analyses}

\begin{tabular}{|ll|}
\hline $\begin{array}{l}\text { Set of protease } \\
\text { inhibitors, final } \\
\text { concentrations: }\end{array}$ & $\begin{array}{l}\text { 1mM PMSF } \\
\text { 1mM EDTA }\end{array}$ \\
$\begin{array}{ll}\text { For cultivated cells } \\
\text { homogenates used in }\end{array}$ & $1 \mathrm{mM}$ PMSF \\
$\begin{array}{l}\text { western blot } \\
\text { analyses: }\end{array}$ & $1,0 \mu \mathrm{g} / \mathrm{ml}$ Leupeptin \\
\hline
\end{tabular}

\section{Tissue - homogenates:}

For estimation of activities of lysosomal enzymes and analyses of different protein expression levels, fresh organs were weighted and each $100 \mathrm{mg}$ tissue were supplemented with $900 \mu \mathrm{TBS}$ ). Tissues were then homogenised using Ultra - Turrax. The obtained 10\% homogenate was supplemented with0,05\% (w/v) Triton X-100 and diluted 1:10 and 1:100. These dilutions and $10 \%$ homogenate were frozen in aliquots at $-80^{\circ} \mathrm{C} .500 \mu \mathrm{l}$ of each $10 \%$ homogenate was supplemented with $1 \%$ Triton X-100 and set of protease inhibitors. That sample was stored at $-20^{\circ} \mathrm{C}$, used for protein concentration determination and western blot analyses.

\section{Cell homogenates:}

MEF or hepatocytes cultivated for one day were washed once with PBS and scraped in 400 $-600 \mu \mathrm{l}$ of TBS, supplemented with protease inhibitors and $0,1 \%$ Triton X-100, and frozen at $-20^{\circ} \mathrm{C}$. Frozen homogenates were sonicated till homogenisation was complete and the protein concentration was determined. 


\subsubsection{Determination of protein concentration using Bradford reagent}

Bradford reagent 4x: BIORAD, München

The reagent was diluted 1:4 right before usage from the stock solution. $1-5 \mu$ of tissue or cell homogenate were adjusted to a volume of $200 \mu$ l. A solution of BSA protein $(0,1 \mathrm{mg} / \mathrm{ml})$ was used as standard. $5,10,15,20 \mu \mathrm{g}$ were pipetted and the volumes were adjusted till $200 \mu \mathrm{l}$. In interval of $15 \mathrm{sec}$ the reaction was started in the protein standards and then in the probes by addition of $800 \mu$ the BIORAD ${ }^{\circledR}$ reagent. After 20 minutes incubation at RT the extinction at $\lambda=660 \mathrm{~nm}$ was measured. A curve was plotted from the standard values and the protein concentrations in the probes were determined from that curve.

\subsubsection{Measuring of activities of lysosomal enzymes in cells and tissues}

\begin{tabular}{|c|c|}
\hline \multicolumn{2}{|c|}{ Substrates for fluorometric estimation of enzymatic activities: } \\
\hline Enzyme & Substrate \\
\hline ß-Hexosaminidase (ß-Hex) & $\begin{array}{l}1 \mathrm{mM} \text { 4-Methyl-Umbelliferyl- } \\
\text { 2-acetamido-deoxy-ß-D-glucopyranosid }\end{array}$ \\
\hline ß- Mannosidase (ß-Man) & $\begin{array}{l}1 \mathrm{mM} 4 \text { Methyl-Umbelliferyl- } \\
\text { ß-D-mannopyranosid }\end{array}$ \\
\hline$\beta-$ Glucuronidase (ß-GlucUA) & $\begin{array}{l}1 \mathrm{mM} 4 \text { Methyl-Umbelliferyl- } \\
\text { ß-D-glucuropyranosid }\end{array}$ \\
\hline$ß-$ Galactosidase (ß-Gal) & $\begin{array}{l}1 \mathrm{mM} 4 \text { Methyl-Umbelliferyl- } \\
\text { ß-D-galaktopyranosid }\end{array}$ \\
\hline
\end{tabular}

Substrate buffer:

$0,1 \mathrm{M} \mathrm{Na}$ citrate $\mathrm{pH} 4,6$

$0,08 \%(\mathrm{w} / \mathrm{v}) \mathrm{NaN}_{3}$

$0,4 \%(\mathrm{w} / \mathrm{v}) \mathrm{BSA}$

Stop - solution:

0,2 M Glycine / NaOH pH 10,8

Assay mixture (see table 2):

$1-10 \mu$ l homogenate $(1: 10$ or $1: 100$ diluted $)$

$50 \mu 1$ substrate solution

were mixed on ice and incubated in a shaking water bath at $37^{\circ} \mathrm{C}$ for the time indicated in table 2

Stop:

$2 \mathrm{ml}$ stop solution

Measuring:

$365 \mathrm{~nm}$ excitation

$410 \mathrm{~nm}$ emission

in fluorescence spectrophotometer 
The measured values were corrected with help of 4-Methylumbelliferone solution as reference probe values. To get stock solution, the powder of 4-MU (Sigma) was dissolved in methanol. Standard solutions of known $0,1 \mathrm{nmol}$ and 1,0 nmol concentrations were obtained by dilution of the stock with $\mathrm{ddH}_{2} \mathrm{O}$ and used to draw a calibration curve for estimation of experimental product amounts. As 0 reference probe $\mathrm{ddH}_{2} \mathrm{O}$ was used. All volumes of standard and 0 reference probes were adjusted till $60 \mu 1$ with $\mathrm{ddH}_{2} \mathrm{O}$ and immediately supplemented with stop-solution. The activities of homogenate were calculated as $\mathrm{mU} / \mathrm{ml}$ :

$1 \mathrm{mU}$ of enzymatic activity corresponds to the accumulation of $1 \mathrm{nmol}$ product per minute of incubation.

\section{Determination of arylsulfatase A activity:}

Substrate solution:

Stop - solution:

Assay mixture (see table 2):

Stop:

Measuring of OD at:
$10 \mathrm{mM}$ p-Nitrocatecholsulfate $10 \%(\mathrm{w} / \mathrm{v}) \mathrm{NaCl}$ $1 \mathrm{mM} \mathrm{Na}$ - pyrophosphate $0,5 \mathrm{M} \mathrm{Na}$ - acetate $\mathrm{pH} \mathrm{5,0}$

\section{$1 \mathrm{M} \mathrm{NaOH}$}

$1-10 \mu$ homogenate $(1: 10$ diluted $)$

$200 \mu$ substrate solution were mixed on ice and incubated in a shaking water bath at $37^{\circ} \mathrm{C}$ for the time indicated in table 2

$600 \mu 1$ of stop - solution were added

$515 \mathrm{~nm}\left(\varepsilon=12400 \mathrm{~cm}^{2} / \mathrm{mmol}\right)$

Calculating the enzymatic activity:

Measured values were corrected with the help of reference probe value $(\Delta \mathrm{E})$. To prepare a reference probe cell homogenates were mixed with the substrate solution and immediately supplemented with the stop solution. Reference probes were incubated together with other probes and then measured. The ASA activity resulted from:

$$
\begin{aligned}
& \text { Assay - vol. in } \mu 1 \text { x } 1000 \text { x } \Delta \mathrm{E} \\
& \text { Probe vol. in } \mu 1 \text { x 12,4 x min }
\end{aligned}
$$


Table 2: Probe volumes and incubation times for measuring of lysosomal enzymes activities.

\begin{tabular}{|l|c|c|c|c|c|c|}
\hline & liver & kidney & brain & spleen & $\begin{array}{c}\text { fibro- } \\
\text { blasts }\end{array}$ & serum \\
\hline B - Hex & $\begin{array}{c}0,05 \\
30\end{array}$ & $\begin{array}{c}0,05 \\
30\end{array}$ & $\begin{array}{c}0,05 \\
30\end{array}$ & $\begin{array}{c}0,05 \\
30\end{array}$ & $\begin{array}{c}0,1 \\
30\end{array}$ & $\begin{array}{c}10 \\
30\end{array}$ \\
\hline ß-Gal & 0,1 & 0,1 & 0,1 & 0,1 & 1 & 1 \\
120 & 120 & 180 & 120 & 120 & 120 \\
\hline B - GlcUA & 0,1 & 0,1 & 1 & 1 & 1 & 1 \\
\hline B -Man & 120 & 120 & 120 & 120 & 120 & 120 \\
\hline ASA & 0,1 & 0,1 & 1 & 1 & 2 & 1 \\
& 60 & 60 & 60 & 60 & 60 & 60 \\
\hline
\end{tabular}

The upper number indicates the probe volume of undiluted homogenate in $\mu \mathrm{l}$.

The lower number shows the incubation time in min. Abbrevations are explaned in the text.

\subsubsection{SDS -polyacrylamide - gel electrophoresis (SDS -PAGE) of proteins}

Separation of protein mixes was done using discontinuous SDS-polyacrylamide-gel electrophoresis.

\begin{tabular}{|c|c|}
\hline Buffer for SDS-PAGE (10x), 11: & $\begin{array}{l}30,2 \mathrm{~g} \text { Tris } \\
144 \mathrm{~g} \text { glycine } \\
10 \mathrm{~g} \text { SDS } \\
\text { in bidistilled } \mathrm{H}_{2} \mathrm{O}\end{array}$ \\
\hline $3 \mathrm{x}$ probe buffer, $45 \mathrm{ml}:$ & $\begin{array}{l}4,5 \mathrm{~g} \text { SDS } \\
18,8 \mathrm{ml} 1 \mathrm{M} \text { Tris- } \mathrm{HCl} \mathrm{pH} 6,8 \\
15 \mathrm{~g} \text { Sucrose } \\
\text { ca. } 5 \mathrm{mg} \text { bromphenolblue (1 spatula -tip) } \\
\text { add } 100 \mu 1 \text { of } ß-\text { mercaptoethanol to each } 900 \mu 1 \text { of } \\
\text { buffer before use }\end{array}$ \\
\hline Acrylamide solution: & $\begin{array}{l}30 \%(\mathrm{w} / \mathrm{v}) \text { acrylamide } \\
0,8 \%(\mathrm{w} / \mathrm{v}) \text { bisacrylamide } \\
\text { in bidistilled } \mathrm{H}_{2} \mathrm{O}\end{array}$ \\
\hline $\begin{array}{l}\text { Ammoniumperoxidisulfate } \\
\text { (APS): }\end{array}$ & $\begin{array}{l}10 \%(\mathrm{w} / \mathrm{v}) \text { ammoniumperoxidisulfate in bidistilled } \\
\mathrm{H}_{2} \mathrm{O}\end{array}$ \\
\hline
\end{tabular}


Table 3: Composition of resolving gel of different polyacrylamide (PAA) concentrations.

\begin{tabular}{|l|c|c|c|c|}
\hline PAA - concentration & $\mathbf{5 \%}$ & $\mathbf{8 \%}$ & $\mathbf{1 1} \%$ & $\mathbf{1 2 , 5 \%}$ \\
\hline $1,5 \mathrm{M}$ Tris- $\mathrm{HCl} \mathrm{pH} 8,8(\mathrm{ml})$ & \multicolumn{4}{|c|}{3,75} \\
\hline acrylamide solution $(\mathrm{ml})$ & 2,5 & 4,0 & 5,5 & 6,25 \\
\hline bidistilled $\mathrm{H}_{2} \mathrm{O}$ & 8,4 & 6,9 & 5,45 & 4,65 \\
\hline $10 \% \mathrm{SDS}(\mu \mathrm{l})$ & \multicolumn{4}{|c|}{150} \\
\hline $10 \% \mathrm{APS}(\mu \mathrm{l})$ & \multicolumn{4}{|c|}{7,50} \\
\hline TEMED $(\mu \mathrm{l})$ & \multicolumn{4}{|c|}{ adjust till $15 \mathrm{ml}$} \\
\hline $\mathrm{H}_{2} \mathrm{O}$ & \multicolumn{4}{|c|}{} \\
\hline
\end{tabular}

Table 4: Composition of stacking gels

\begin{tabular}{|l|l|}
\hline PAA concentration: & $5,5 \%$ \\
\hline $1 \mathrm{M}$ Tris- $\mathrm{HCl} \mathrm{pH} 6,8$ & $936 \mu \mathrm{l}$ \\
\hline Acrylamide solution & $1,39 \mathrm{ml}$ \\
\hline $10 \%$ SDS & $75 \mu \mathrm{l}$ \\
\hline $10 \%$ APS & $150 \mu \mathrm{l}$ \\
\hline TEMED & $7,5 \mu \mathrm{l}$ \\
\hline $\mathrm{H}_{2} \mathrm{O}$ & adjust till $7,5 \mathrm{ml}$ \\
\hline
\end{tabular}

Electrophoresis was done always in vertical directed glass plates (the size of glass plates is: $18 \times 14 \mathrm{~cm}, 1 \mathrm{~mm}$ spacer). Glass plates were put together with spacers between them and were hermetically sealed with $1 \%$ agarose in water. Freshly mixed separating gel was poured between plates and $500 \mu \mathrm{l}$ of $\mathrm{H}_{2} \mathrm{O}$ was put on the top. After $30 \mathrm{~min}$ of polymerisation at $\mathrm{RT}, \mathrm{H}_{2} \mathrm{O}$ was sucked out using a pump, stacking gel was poured and a comb was inserted. After 10 min of polymerisation, the rack was removed and gel pockets were rinsed with water. Rests of polymerised gel were removed from the pockets with a hypodermic needle. Gel pockets were filled with buffer for electrophoresis (see above). Protein probes were mixed with $3 \mathrm{x}$ buffer $(2: 1)$, denaturated for $5 \mathrm{~min}$ at $95^{\circ} \mathrm{C}$, centrifuged $1 \mathrm{~min}$ at $14000 \mathrm{rpm}$ at RT and loaded into gel pockets. Electrophoresis was run at $32 \mathrm{~mA}$ for $2-3$ hours. 


\subsubsection{Semi-dry protein transfer (western - blotting)}

\begin{tabular}{|l|l|}
\hline A buffer for semi - dry protein & $5,8 \mathrm{~g}$ Tris \\
transfer (1L): & $2,92 \mathrm{~g}$ glycine \\
& 3,7 ml SDS $10 \%$ \\
& pH about 9,2 and add $\mathrm{H}_{2} \mathrm{O}$ to $800 \mathrm{ml}$ \\
& and $200 \mathrm{ml}$ of methanol \\
\hline
\end{tabular}

6 pieces of whatman GB 003 paper and nitrocellulose membrane (or PVDF membrane) were cut out in a size of the gel. PVDF membrane was soaked for $1 \mathrm{~min}$ in absolute methanol (Roth) or in $60 \%$ methanol (Westran ${ }^{\circledR}$ ) depending on kind of purchased membrane. Whatman paper and membrane were pre- wet in a semi - dry buffer for $1 \mathrm{~min}$. Whatman paper was placed directly onto an electrode surface (3 layers), then membrane and all air bubbles were removed between them. After SDS-PAGE, the stacking gel was removed and the resolving gel was soaked in the semi - dry buffer shortly, before placing it onto the membrane. The gel surface was covered again by 3 layers of wet whatman paper and air bubbles were removed. A second electrode was put onto the top of the unit so the device was fully assembled and then connected to a power supply. The transfer followed from cathode to anode for $1 \mathrm{~h}$ under $1 \mathrm{~mA} / \mathrm{cm}^{2}$. The efficiency of the transfer was controlled using Ponceau ${ }^{\circledR}$ solution that stains protein bands on membranes. The membrane was soaked in the solution for $5-20$ min and rinsed with water till an excess of Ponceau was removed. The membrane was air - dried and stored at RT till use in ECL protein detection assay.

\subsubsection{Antibody - staining and enhanced chemiluminiscent (ECL) assay for protein detection}

\section{Background information:}

The protein of interest was identified via interaction with a mouse or rabbit antibody specific to that protein, which was detected by goat-HRP (horse-redish-peroxidase) conjugated antibody directed against either mouse or rabbit IgG. 
Table 5: Antibodies dilutions for ECL-detection assay

\begin{tabular}{|l|c|c|c|}
\hline \multicolumn{1}{|c|}{ Protein } & MW & $\begin{array}{c}\text { Primary } \\
\text { antibody } \\
\text { dilution }\end{array}$ & $\begin{array}{c}\text { Secondary } \\
\text { antibody } \\
\text { dilution }\end{array}$ \\
\hline $\begin{array}{l}\text { Cathepsin D, } \\
\text { murine }\end{array}$ & $50,30,14$ & $1: 200$ & $1: 20000$ \\
\hline Lamp1, murine & 110 & $1: 300$ & $1: 10000$ \\
\hline Lamp2, murine & 110 & $1: 100$ & $1: 10000$ \\
\hline $\begin{array}{l}\text { LimpII, rat, luminal } \\
\text { domane }\end{array}$ & 90 & $1: 500$ & $1: 10000$ \\
\hline $\begin{array}{l}\text { MPR-46, } \\
\text { cytoplasmic domain }\end{array}$ & 46 & $1: 272$ & $1: 10000$ \\
\hline mVti1a & 29 & $1: 3000$ & $1: 20000$ \\
\hline mVti1b & 29 & $1: 1000$ & $1: 20000$ \\
\hline SNAP - 29 & 30 & $1: 1000$ & $1: 20000$ \\
\hline Syntaxin 7 & 170 & $1: 200$ & $1: 10000$ \\
\hline Syntaxin 8 & 180 & $1: 1000$ & $1: 10000$ \\
\hline $\begin{array}{l}\text { Transferrin receptor, } \\
\text { human }\end{array}$ & 17000 & $1: 20000$ \\
\hline EGF-R & 27 & $1: 20000$ \\
\hline
\end{tabular}

Solutions:

\begin{tabular}{|l|l|}
\hline PBST: & PBS with 0,1\% Tween-20® \\
\hline Blotto: & $\begin{array}{l}2 \% \text { milk powder in PBST (for nitrocellulose } \\
\text { membrane) } \\
\text { or } \\
5 \% \text { milk powder in PBST (for PVDF } \\
\text { membrane) }\end{array}$ \\
\hline $\begin{array}{l}\text { SuperSignal }{ }^{\circledR} \text { chemiluminiscence } \\
\text { substrate }\end{array}$ & $\begin{array}{l}\text { PIERCE } \\
\text { mix in equal amounts directly before use }\end{array}$ \\
\hline
\end{tabular}

A protein - blot (see under 3.3.2.5) was washed in water till the Ponceau disappeared and soaked in blotto for $30 \mathrm{~min}$. The desired primary antibody was diluted (see 3.1.8.1) in blotto and the blot was put into its solution in a sealed plastic bag ( to reduce volume of antibody used). The blot was then incubated for $1-2 \mathrm{~h}$, followed by washing in PBST 3 times for $5 \mathrm{~min}$ and then incubated again for $1 \mathrm{~h}$ with anti- mouse or anti- rabbit secondary 
antibody diluted in PBST. Finally the blot was washed 5 times 5 min with PBST and one time with PBS. The membrane was put into SuperSignal ${ }^{\circledR}$ mixture for 5 minutes with shaking and then exposed to KODAK film or luminescent image analyser for different times, depending on signal intensity.

\subsubsection{Metabolic labelling of cells for immunoprecipitation of lysosomal protease Cathepsin D}

Adherent mouse embryonic fibroblasts and hepatocytes were incubated in the presence of radioactive $\left[{ }^{35} \mathrm{~S}\right]-$ methionine for later immunoprecipitation of the lysosomal enzyme cathepsin D.

\begin{tabular}{|l|l|}
\hline Starvation medium: & $\begin{array}{l}5 \%(\mathrm{v} / \mathrm{v}) \text { dialysed, heat - inactivated FKS in DMEM } \\
\text { without methionine }\end{array}$ \\
\hline Labelling medium: & $\begin{array}{l}100-200 \mu \mathrm{Ci} / \mathrm{ml}\left[{ }^{35} \mathrm{~S}\right]-\text { methionine in starvation } \\
\text { medium }\end{array}$ \\
\hline $\begin{array}{l}\text { Chase medium supplement } \\
(100 \mathrm{x}):\end{array}$ & $25 \mathrm{mg} / \mathrm{ml}$ L-methionine in $\mathrm{H}_{2} \mathrm{O}$, sterile filtered \\
\hline Lysis - buffer: & $\begin{array}{l}0,1 \%(\mathrm{w} / \mathrm{v}) \text { Triton } \mathrm{X}-100 \\
1 \mathrm{mM} \text { PMSF } \\
1 \mathrm{mM} \text { EDTA } \\
5 \mathrm{mM} \mathrm{JAA} \\
\text { in TBS pH } 7,4\end{array}$ \\
\hline
\end{tabular}

Methabolic labelling of adherent cells with $\left[{ }^{35} \mathrm{~S}\right]$ - methionine:

Cells were plated in $3 \mathrm{~cm}$ culture dishes one day before labelling. The amount of fibroblasts was chosen so that on the day of the experiment cells were almost confluent. Hepatocytes were always plated after their isolation at $6,5 \times 10^{5}$ cells per plate (see under 3.3.1.4). Cells were washed once with PBS and once with starvation medium and then incubated in $1 \mathrm{ml}$ of starvation medium for $1 \mathrm{~h}$ at $37^{\circ} \mathrm{C}, 5 \% \mathrm{CO}_{2}$. After that the medium was changed to $0,6 \mathrm{ml}$ of radioactive labelling medium and plates were put into an incubator again for $1 \mathrm{~h}$ ("pulse"). For starting of the chase period (1-6h) $6 \mu \mathrm{l}$ of 100x methionine stock - solution were added to the labelling medium (end concentration: $250 \mu \mathrm{g} / \mathrm{ml})$. Media after the chase periods were collected, centrifuged $1 \mathrm{~min}$ at $14000 \mathrm{rpm}$ to remove cell debris and upernatants were frozen at $-20^{\circ} \mathrm{C}$ till use in the immunoprecipitation experiment. Cells were washed twice with cold PBS and scraped off in 2 x $200 \mu \mathrm{l}$ cold lysis buffer using a cell scraper. The obtained cell lysates were stored at $-20^{0} \mathrm{C}$ till use. 


\subsubsection{Washing of pansorbin}

The desired amount of pansorbin (usually $1 \mathrm{ml}$ ) was put into a $2 \mathrm{ml}$ eppendorf tube and centrifuged $1 \mathrm{~min}$ at $10000 \mathrm{rpm}$ at RT. The obtained pellet was resuspended in $1 \mathrm{ml}$ of PBS and centrifuged again with same conditions. The procedure was repeated 4 times and then pellet was resuspended in starting volume of PBS and stored at $4^{0} \mathrm{C}$ overnight till use.

\subsubsection{Immunoprecipitation of metabolically labelled cathepsin D}

All steps for the immunoisolation were done in a cold room, or on ice using cold solutions.

\begin{tabular}{|c|c|}
\hline Wash - immunomix (IMM): & $\begin{array}{l}1 \%(\mathrm{w} / \mathrm{v}) \text { Triton } \mathrm{X}-100 \\
0,05 \%(\mathrm{w} / \mathrm{v}) \mathrm{Na}-\text { deoxycholate } \\
10 \mathrm{mM} \mathrm{Na}-\mathrm{phosphate}, \mathrm{pH} 7,4 \\
0,15 \mathrm{M} \mathrm{NaCl} \\
\text { store at }-20^{0} \mathrm{C}\end{array}$ \\
\hline $2 \mathrm{M} \mathrm{KCl}$ - immunomix & $\begin{array}{l}2 \mathrm{M} \mathrm{KCl} \text { in wash - immunomix } \\
\text { store at }-20^{\circ} \mathrm{C}\end{array}$ \\
\hline Neufeld - buffer: & $\begin{array}{l}10 \mathrm{mM} \text { Tris, } \mathrm{pH} 8,5 \\
0,6 \mathrm{M} \mathrm{NaCl} \\
0,1 \% \mathrm{SDS} \\
0,05 \% \mathrm{NP}-40 \\
\text { store at }-20^{\circ} \mathrm{C} \\
\end{array}$ \\
\hline $\begin{array}{l}\text { Precipitation - immunomix } \\
\text { (PIM): }\end{array}$ & $\begin{array}{l}0,2 \% \text { SDS } \\
10 \% \text { BSA } \\
1 \mathrm{mM} \text { PMSF } \\
1 \mathrm{mM} \text { EDTA } \\
5 \mathrm{mM} \mathrm{JAA} \\
\text { in wash - immunomix }\end{array}$ \\
\hline Protaminsulfate: & $\begin{array}{l}3 \% \text { protaminsulfate, }(\mathrm{SERVA}) \text { in } \mathrm{H}_{2} \mathrm{O} \\
\text { always fresh prepared }\end{array}$ \\
\hline Pansorbin: & was washed as described under 3.3.2.8 \\
\hline $\begin{array}{l}\text { Destaining solution for SDS- } \\
\text { PAGE: }\end{array}$ & $\begin{array}{l}50 \% \text { methanol (technical grade) } \\
10 \% \text { acetic acid (technical grade) } \\
40 \% \mathrm{H}_{2} \mathrm{O}\end{array}$ \\
\hline
\end{tabular}

Cell lysates and media after metabolic labelling (see under 3.3.2.7) were thawed and put on ice. Cell lysates were then sonicated (30 sec at max) till complete homogenisation was achieved. Cell debris was removed by centrifugation for $5 \mathrm{~min}$ at $14000 \mathrm{rpm}$ and clear cell lysates were transferred into new tubes. 0,8 volume precipitation immunomix (PIM) (480 $\mu 1$ to each media and $320 \mu 1$ to each cell lysate) was added to each tube. To remove 
genomic DNA, 1/100 volume of protamin sulfate solution was added to each tube of cell lysate and incubated on ice for $10 \mathrm{~min}$ with following centrifugation for $2 \mathrm{~min}$ at 14000 rpm. Clear lysates were transferred into new tubes. Afterwards $3 \mu 1$ of preimmune serum and $60 \mu 1$ of non-washed pansorbin were added to all tubes. Tubes were incubated on a lab - rotator for $6 \mathrm{~h}$ followed by centrifugation for $10 \mathrm{~min}$ at $14000 \mathrm{rpm}$. Clear liquids were transferred into new tubes without taking any pansorbin and $3 \mu 1$ of $\alpha$-mouse cathepsin D antibody were added. Tubes were incubated on a rotator $\mathrm{ON}$ with slow rotation. $60 \mu 1$ of pre - washed pansorbin were added and tubes incubated for $1 \mathrm{~h}$ with rotation. Tubes were centrifuged $10 \mathrm{~min}$ at $14000 \mathrm{rpm}$, supernatants transferred into new tubes and frozen at $20^{\circ} \mathrm{C}$. Pansorbin pellets were washed with $0,8 \mathrm{ml}$ of:

1) neufeld buffer

2) wash-immunomix

3) $\mathrm{KCl}$-immunomix

4) PBS (1:10)

; each time resuspended and centrifuged $1 \mathrm{~min}$ at $14000 \mathrm{rpm}$, the supernatant was removed with a peristaltic pump. The pellet was resuspended in $60 \mu 1$ of $2 \mathrm{x}$ stop buffer (see under 3.3.2.4) and incubated $5 \mathrm{~min}$ at $95^{\circ} \mathrm{C}$ to solubilize immunoprecipitated protein. Tubes were again centrifuged $3 \mathrm{~min}$ at $14000 \mathrm{rpm}$ at RT and $35 \mu \mathrm{l}$ of the supernatants were loaded onto $12,5 \%$ SDS-PAGE. After electrophoresis (see under 3.3.2.4) the gel was soaked in destaining solution for $30 \mathrm{~min}$ with shaking on a rocker. The gel was then rinsed 3 times with water and left on a rocker for $5 \mathrm{~min}$ in water, placed between 2 cellophane sheets and dried for about $1,5 \mathrm{~h}$. The dry gel was exposed with a phosphoimager - screen for 1-4 days and the image obtained was quantified using the Image Gauge software (Fuji).

\subsubsection{Degradation of long - live proteins by mouse hepatocytes}

To estimate rates of autophagocytosis in control and mVtilb deficient cells an in-vivo labelling with $\left[{ }^{14} \mathrm{C}\right]$ - valine was applied.

Krebs-Heinseleit buffer:

RPMI medium:
SIGMA, Deisenhofen add $2,1 \mathrm{~g} / \mathrm{L} \mathrm{NaHCO}_{3}$ to solution, store at $4^{0} \mathrm{C}$ GIBCO BRL, Eggenstein $5 \%$ FKS dialysed, heat inactivated 
Mouse hepatocytes were isolated as described under 3.3.1.4. Each time 6 plates of control and 6 plates of Vtilb deficient hepatocytes cultivated overnight were taken for an experiment. Cells were washed with PBS once to remove dead cells and incubated in $1 \mathrm{ml}$ $\left[{ }^{14} \mathrm{C}\right]$ - valine RPMI medium for $24 \mathrm{~h}(0,63 \mu \mathrm{Ci} / \mathrm{ml})$. The medium was removed and cells were washed twice with Krebs-Heinseleit buffer to remove radiactive valine in the medium. Two plates were then incubated for $1 \mathrm{~h}$ with $1 \mathrm{ml}$ of Krebs-Heinseleit buffer + $0,1 \%$ BSA $+15 \mathrm{mM}$ "cold" valine to induce autophagocytosis because of the removal of serum and four plates were incubated same time with $15 \mathrm{mM}$ non-radioactive valine containing RPMI medium. After finishing of the $1 \mathrm{~h}$ chase period, media were collected to compare how fast short-live proteins were degraded in both groups of cells studied. New portions of buffer and medium were added to the plates. Cells were incubated with KrebsHeinseleit buffer for $3 \mathrm{~h}$ more, medium was then collected and cells were scraped up in $500 \mu 1$ of PBS $+0,1 \%$ Triton X-100. Two plates were incubated with non radioactive valine medium for $11 \mathrm{~h}$ and two plates for $23 \mathrm{~h}$, medium was then collected and cells were scraped off in $500 \mu \mathrm{l}$ of PBS $+0,1 \%$ Triton $\mathrm{X}-100$. Soluble radioactivity was separated from unsoluble via TCA precipitation. 1/5 volume of 50\% TCA (trichloracetic acid) were added to collected media and cells and mixed. After $10 \mathrm{~min}$ of incubation on ice, precipitates were separated from supernatants after $10 \mathrm{~min}$ centrifugation at $14000 \mathrm{rpm}, 4^{0} \mathrm{C}$. Pellets were solubilised in $500 \mu \mathrm{l}$ of $500 \mathrm{mM} \mathrm{NaOH}$ solution. All soluble and unsoluble radioactivity was counted in a scintillation counter and protein degradation was expressed as $\%$ of soluble radioactivity in relation to total radioactivity.

\subsubsection{Immunofluorescent localisation of proteins}

For comparison of protein distribution in MEF and cultivated hepatocytes an immunofluorescent localisation was done on control and knock-out cells.

Mouse embryonic fibroblasts were plated on coverslips about 3-4 days before experiment so, that on a day of experiment cells were almost confluent. Hepatocytes were plated in an amount of $1,5 \times 10^{5}$ cells per coverslip (see under 3.3.1.4). 
Table 6: Antibodies dilutions for immunofluorescent protein localisation

\begin{tabular}{|c|c|c|c|c|}
\hline Protein & $\begin{array}{l}\text { Primary } \\
\text { antibody } \\
\text { dilution }\end{array}$ & $\begin{array}{c}\text { Secondary } \\
\text { antibody } \\
\text { type }\end{array}$ & $\begin{array}{l}\text { Secondary } \\
\text { antibody } \\
\text { dilution }\end{array}$ & $\begin{array}{l}\text { Method of } \\
\text { fixation }\end{array}$ \\
\hline $\begin{array}{l}\text { Cathepsin } \mathrm{D} \text {, } \\
\text { murine }\end{array}$ & $1: 100$ & $\alpha$-rabbit & \multirow{9}{*}{$1: 200$} & methanol \\
\hline Lamp1, murine & $1: 200$ & $\alpha$-rat & & methanol \\
\hline Lamp2, murine & $1: 200$ & $\alpha$-rat & & methanol \\
\hline $\begin{array}{c}\text { MPR-46, } \\
\text { cytoplasmic } \\
\text { domain }\end{array}$ & $1: 100$ & $\alpha$-rabbit & & PFA \\
\hline mVtila & $1: 400$ & $\alpha$-rabbit & & PFA \\
\hline mVtilb & $1: 400$ & $\alpha$-rabbit & & PFA \\
\hline Syntaxin 7 & $1: 200$ & $\alpha$-rabbit & & PFA \\
\hline Syntaxin 8 & $1: 200$ & $\alpha$-rabbit & & PFA \\
\hline$\gamma$-adaptin & $1: 100$ & $\alpha$-mouse & & methanol \\
\hline
\end{tabular}

\section{Paraformaldehyde (PFA) fixation method for immunofluorescent localisation:}

Cells were washed once with PBS at RT and incubated for 30 min with 3\% PFA in PBS. Fixed cells were washed twice with PBS and blocked with $50 \mathrm{mM} \mathrm{NH}_{4} \mathrm{Cl}$ solution in PBS for $10 \mathrm{~min}$. Then cells were permeabilised with $0,05 \%$ Triton X-100 in PBS and blocked with 1\% BSA in PBS solution. Primary antibodies were diluted as indicated in table 6 in $1 \%$ BSA - PBS and $15 \mu 1$ of the solution was dropped onto parafilm. Coverslips were taken out from a 24 -well culture plate with tweezers and turned upside down onto the antibody solution. Cells were incubated in that way for $1 \mathrm{~h}$ in a humid dark chamber and then returned to the 24-well plate (turned again, so cells were always exposed to the solution). Coverslips were washed with PBS 3 times for $5 \mathrm{~min}$ and incubated with $10 \%$ goat serum in PBS for $20 \mathrm{~min}$. Secondary antibodies (Cy2, Cy3, FITC or TR-conjugates) were diluted as indicated in table 6 and coverslips were incubated with $15 \mu$ of the appropriate solution in a humid dark chamber like it was done before with the primary antibodies. Cells were then washed 5 times for 5 min with PBS and rinsed 3 times with 
water. Fully treated coverslips were mounted into a special mounting medium $\left(\mathrm{DAKO}{ }^{\mathrm{B}}\right.$, Carpinteria, CA) and left ON at RT to solidify the mounting medium.

\section{Methanol fixation method for immunofluorescent localisation:}

Cells were washed twice with pre-warmed at $37^{\circ} \mathrm{C}$ PBS $+5 \mathrm{mM}$ glucose and put on ice. One washing step more with ice-cold PBS was done before cells were fixed with $-20^{\circ} \mathrm{C}$ methanol for $5 \mathrm{~min}$. Coverslips were then washed twice with PBS-glucose at RT and twice with PBS at RT. After that cells were blocked with 1\% BSA in PBS solution.

Incubation with diluted primary antibodies as well as all later steps were done as described above for the PFA fixation method.

\subsubsection{FITC-dextran uptake by mouse embryonic fibroblasts (MEF)}

Control and mVtilb deficient MEF were grown on coverslips till they almost reached confluence. FITC-dextran $(\mathrm{MW}=14000)$ solution $(100 \mathrm{mg} / \mathrm{ml})$ was thawed and span down for $15 \mathrm{sec}$ at $13000 \mathrm{rpm}, 4^{0} \mathrm{C}$. The supernatant was used for the experiment. $2,8 \mathrm{ml}$ of DMEM supplemented with $10 \%$ FKS were mixed with $56 \mu 1$ of the supernatant. $200 \mu 1$ of the mixture obtained was used to cover cells and they were put immediately into an incubator at $37^{\circ} \mathrm{C}$ for $1 \mathrm{~h}$ (pulse). After the FITC-dextran incubation cells were washed once with PBS at $37^{\circ} \mathrm{C}$ and kept for the chosen chase periods with DMEM at $37^{\circ} \mathrm{C}$.

Following chase periods were done afterwards:

1) $0 \mathrm{~min}$

2) $30 \mathrm{~min}$

3) $1 \mathrm{~h}$

4) $2 \mathrm{~h}$

The cells were then fixed with 3\% PFA in PBS for 30 min at RT, washed twice with PBS, rinsed with water and mounted in DAKO ${ }^{\circledR}$ medium (see 3.3.2.11)

\subsubsection{Endocytosis of fluorescently labelled LDL}

Vtilb deficient and control MEF were grown on coverslips till they were almost confluent. Cells were washed twice with PBS to remove dead cells and FKS from the medium and incubated with serum-free DMEM supplemented with $1 \% \mathrm{BSA}$ for $2 \mathrm{~h}$ at $37^{\circ} \mathrm{C}$ (starvation). Starvation medium was then replaced with DMEM $+1 \% \mathrm{BSA}+10 \mu \mathrm{g} / \mathrm{ml}$ fluorescently labelled low-density-lipoprotein (BODIPY®, Molecular Probes, USA) and cells were put 
on ice for $90 \mathrm{~min}$ (receptor binding). Cells were washed with PBS at RT twice and incubated for following chase periods at $37^{0} \mathrm{C}$ in DMEM + $1 \%$ BSA:

1) $0 \mathrm{~min}$

2) $15 \mathrm{~min}$ (fluorescent signal in lysosomes)

3) 30 min (fluorescent signal in lysosomes)

4) $1 \mathrm{~h}$ (partial degradation was expected)

5) $3 \mathrm{~h}$ (complete degradation was expected)

After finishing of each chase period coverslips were washed twice with PBS at RT, then fixed with 3\% PFA in PBS for 30 min at RT, washed twice with PBS, rinsed with water and mounted in DAKO ${ }^{\circledR}$ medium (see 3.3.2.11).

\subsubsection{Epidermal growth factor receptor (EGF-R) uptake and degradation in MEF and cultivated hepatocytes}

\section{Background information:}

EGF is known to be endocytosed together with its receptor, which is then transported to lysosomes for degradation.

\begin{tabular}{|l|l|}
\hline Starvation medium for MEF: & DMEM + 1\% BSA, without FKS \\
\hline $\begin{array}{l}\text { Starvation medium for } \\
\text { hepatocytes: }\end{array}$ & RPMI + 1\% BSA, without FKS \\
\hline Lysis - buffer: & $\begin{array}{l}0,1 \%(\mathrm{w} / \mathrm{v}) \text { Triton X-100 } \\
1 \mathrm{mM} \text { PMSF } \\
1 \mathrm{mM} \text { EDTA } \\
5 \mathrm{mM} \mathrm{JAA} \\
\text { in TBS pH 7,4 }\end{array}$ \\
\hline $\begin{array}{l}\text { Epidermal growth factor (EGF), } \\
\text { murine }\end{array}$ & $\begin{array}{l}\text { sterile } 100 \mu \mathrm{g} / \mathrm{ml} \text { stock solution in } \mathrm{H}_{2} \mathrm{O}, \text { Calbiochem, } \\
\text { Frankfurt }\end{array}$ \\
\hline rabbit $\alpha$ EGF-R antibody: & $\begin{array}{l}200 \mu \mathrm{g} / \mathrm{ml}, 1: 200 \text { dilution, Santa Cruz Biotechnology } \\
\text { Inc. } ; 1: 10000 \text { dilution of secondary antibody }\end{array}$ \\
\hline
\end{tabular}

Mouse embryonic fibroblasts were plated on $3 \mathrm{~cm}$ plates so that on the day of the experiment they were confluent. Hepatocytes were plated at $6,5 \times 10^{5}$ cells per $3 \mathrm{~cm}$ plate (see 3.3.1.4). 6 control and 6 "knock-out" plates were used for each experiment.

On the day of the experiment, cells were washed twice with $1 \mathrm{ml}$ of starvation medium and left in same medium at $37^{\circ} \mathrm{C}$ for $1 \mathrm{~h}$ (starvation). One experiment was done with starvation for $2 \mathrm{~h}$ resulting in more strong EGF-R signal. Two control and two "knock-out" plates were then put on ice for collecting the cells, which have the starting amount of EGF-R. 
Medium was replaced with medium containing $500 \mathrm{ng} / \mathrm{ml}$ (for MEF) or $100 \mathrm{ng} / \mathrm{ml} \mathrm{EGF}$ (for hepatocytes) and cells were left in an incubator at $37^{\circ} \mathrm{C}$ for different chase periods:

$2 \mathrm{~h}$

$4 \mathrm{~h}$

After finishing of every chase period, plates were put on ice, washed twice with cold PBS and scraped off in $2 \times 200 \mu$ of lysis buffer. Cell lysates were frozen at $-20^{\circ} \mathrm{C}$ till use for determination of the protein concentration (see 3.3.2.2). 100 $\mu \mathrm{g}$ protein was separated by an SDS-PAGE using a 5\% gel (3.3.2.4), western blotting (3.3.2.5). Western blots were incubated with anti-EGF-R antibodies and protein bands were visualised after using ECL assay in the CCD-camera. Bands were quantified using AIDA software (Fuji). Finally EGF-R degradation rate was expressed in \% of intensity of the band after the chase in comparison to its starting amount ( $0 \mathrm{~min})$ after detection of EGF-R bands in ECL assay (3.3.2.6)

\subsubsection{Uptake and degradation of ${ }^{125}$ I-asialofetuin in mouse hepatocytes}

(modified from Tolleshaug et al.(Tolleshaug et al. 1977))

\section{Background information:}

The asialoglycoprotein receptor (ASGR) expressed in hepatocytes allows for the endocytosis of asialogycoproteins within short periods of time. ASGR is then recycled back to the plasma membrane whereas endocytosed material is transported to lysosomes for degradation. Iodinated asialofetuin is used in this assay as tracer of endocytosis, lysosomal delivery and degradation. Upon measuring of the soluble radioactivity in medium and cells, rates of lysosomal degradation can be calculated as percents of total radioactivity.

\section{Iodination of asialofetuin:}

\begin{tabular}{|l|l|}
\hline Elution buffer & $0,1 \% \mathrm{KJ}, 0,05 \%$ BSA in PBS \\
\hline NAP-column (Pharmacia): & Equilibrate with $30 \mathrm{ml}$ of elution buffer \\
\hline IODO-Gen ${ }^{\circledR}$ pre-iodinated tubes & PIERCE, Rockford, IL, USA \\
\hline $\mathrm{Na}^{125} \mathrm{I}$ & Amersham- Buchler, Braunschweig \\
\hline Asialofetuin & Sigma, Diesenhofen \\
\hline
\end{tabular}


One $\mathrm{mg} / \mathrm{ml}$ of asialofetuin was dissolved in PBS and $64 \mu \mathrm{l}(64 \mu \mathrm{g}=1 \mathrm{nmol})$ were diluted with $186 \mu 1$ PBS. The obtained solution was loaded onto the bottom of a IODO-Gen $\AA$ tube and $1 \mu \mathrm{l}(100 \mu \mathrm{Ci})$ of $\mathrm{Na}^{125}$ I was added under a fume hood. The tube was incubated at RT for $15 \mathrm{~min}$ with careful flicking. After incubation the radioactive mixture was removed from the IODO-Gen ${ }^{\circledR}$ tube and transferred into an eppendorf tube containing $250 \mu 1$ of elution buffer. The obtained mixture was loaded onto a NAP-column, rests of the mixture from eppendorf tube were diluted with $500 \mu \mathrm{l}$ of elution buffer and also loaded onto the column. The protein was eluted in $10 \mathrm{x} 500 \mu \mathrm{l}$ of elution buffer with collecting all 10 fractions in separate tubes. Two $\mu 1$ of each fraction were measured for radioactivity in $\gamma$ counter. In our case fractions 7 and 8 contained the desired radioactive asialofetuin. These fractions were pooled and used for the uptake assay. Labelled asialofetuin solution was stored at $4^{0} \mathrm{C}$ for up to four weeks.

\section{Uptake and degradation of labelled asialofetuin by adherent hepatocytes:}

Hepatocytes were prepared as described in 3.3.1.4. Eight plates of each type, control and Vtilb deficient hepatocytes were used. Cells were washed twice with RPMI without FKS supplemented with $0,1 \%$ BSA and starved in that medium for $4 \mathrm{~h}$. Starvation medium was replaced with new starvation medium containing $10 \mathrm{pmol} / \mathrm{ml}$ of ${ }^{125} \mathrm{I}$-asialofetuin $(1: 100$ dilution of labelled solution, $6 \mu \mathrm{l}$ in $600 \mu \mathrm{l}$ of medium for each plate).Two $600 \mu \mathrm{l}$ aliquotes of radioactive medium were pipetted into separate tubes for control of background degradation of asialofetuin in the medium. The first tube was placed on ice immediately and second one after the end of the last chase period. All plates were exposed to the radioactive medium for $20 \mathrm{~min}$ (pulse). After the end of the pulse period, plates were washed once with $1 \mathrm{ml}$ non-radioactive medium and supplemented with $600 \mu \mathrm{l}$ of new medium. The following chase periods were started:

$0 \mathrm{~min}$

$30 \mathrm{~min}$

$60 \mathrm{~min}$

$120 \mathrm{~min}$

Two control and two Vtilb knock-out plates were used for each time point. After the end of the chase period, medium was collected in separate tubes and plates were washed twice with PBS. Cells were scraped off in $500 \mu \mathrm{l}$ of PBS $+0,2 \%$ Triton X-100 and lysates were transferred into screw cup tubes. The collected medium and cell lysates were precipitated 
with $10 \%$ TCA for 10 min on ice. Soluble and unsoluble radioactivity was separated by centrifugation at $14000 \mathrm{rpm}, 4^{0} \mathrm{C}$ and supernatants were transferred into new tubes. TCA pellet were dissolved in $500 \mu \mathrm{l}$ of $0,5 \mathrm{M} \mathrm{NaOH}$. The radioactivity of all obtained probes was then measured in $\gamma$-counter. Degradation of asialofetuin was calculated as $\%$ of the sum of soluble radioactivity in the medium and cells compared to the sum of soluble radioactivity and the insoluble radioactivity in the cells. 


\section{$4 \quad$ Results}

\subsection{Generation of Vti1b deficient mice}

\subsubsection{Isolation of genomic DNA for Vti1b, characterisation of Vti1b chromosomal region and construction of a targeting vector}
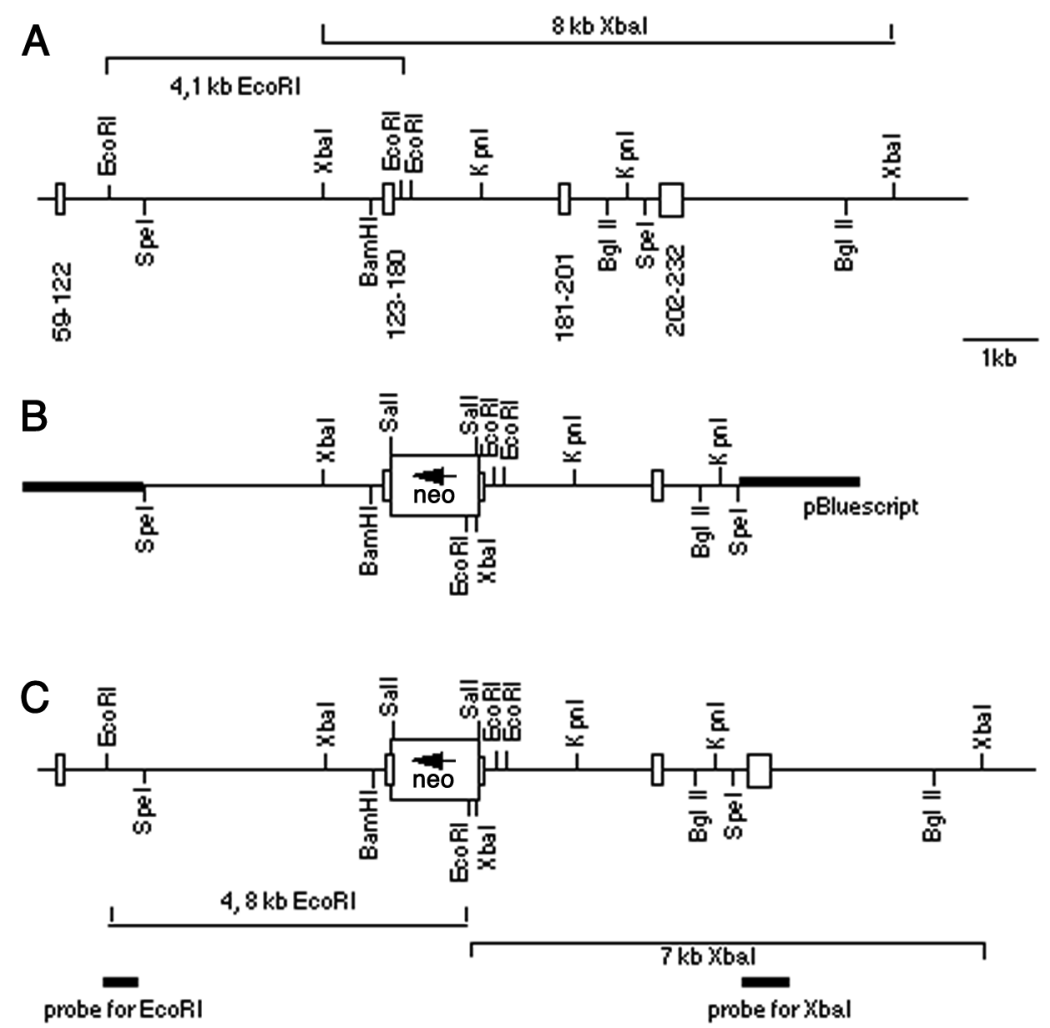

Figure 8: Schema of Vti1b genomic sequence, targeting vector and the screening strategy for detection of positive ES clones. A) mVtilb genomic sequence; B) targeting construct; C) strategy for detection of positive ES cell clones using DNA hybridisation techniques

An EST (express sequence tag) clone (Genebank accession number AA105524) was purchased from american type culture collection (ATCC). The clone " 235 " contained the whole coding sequence of mVtilb, 70bp 5 untranslated region and 200bp 3 'untranslated region as cDNA in a pCMV-SPORT2 vector. The insert was cut out by SalI+NotI digestion and used as DNA probe for screening of a $\lambda$-phage mouse genomic DNA library of the strain Sv129 Ola as described under 3.2.7.2, 3.2.7.3 and 3.2.7.4. One phage clone was detected ("phage A"), its DNA amplified and the $15 \mathrm{~kb}$ mouse DNA insert was cut out of the phage vector using NotI. This chromosomal DNA fragment was subcloned into the 
$\mathrm{pSK}^{+}$Bluescript vector and mapped. A simplified map of the mVtilb chromosomal region is shown in fig. 8

The obtained mVtilb chromosomal DNA fragment contains 4 exones, starting from the exon encoding amino acids "59-122" and ending with the exon encoding the C-terminal amino acid residues 202-232 and the 3 'untranslated region. The exon "123-180" encodes part of the SNARE motif that is crucial for Vtilb function. Disruption of the exon "123180 " by the Neo-cassette would prevent synthesis of Vtilb protein even in the unlikely case that the resulting mRNA is stable. The subcloned $7 \mathrm{~kb}$-long SpeI DNA fragment containing the exon 123-180 was used for making a targeting construct. A SalIendonuclease recognition site was introduced into the exon "123-180" by site-directed mutagenesis and a targeting vector constructed by inserting the Neo-cassette into this side. The construct has 3,5kb DNA for homological recombination on each side of the exon interrupted by the Neo-cassette. Sequences on both sides of the SpeI fragment were known from phage mapping and used for design of DNA probes. The plasmid $\mathrm{pVA}_{12}$ was obtained by SpeI shrinking of the plasmid $\mathrm{pVA}_{4}$ containing the complete $15 \mathrm{~kb}$ of the phage DNA insert. $\mathrm{pVA}_{12}$ contains the first part of the phage with exon 59-122 til the first SpeI site. The 5 ' external probe "EcoRI-derived probe" consists of a 400bp fragment obtained by restriction digestion of the $\mathrm{pVA}_{12}$ DNA with EcoRI. pVA 7 contained exon "202-232" inside of a 3,2kb BglII DNA fragment from phage A . Using oligonucleotides CCATGAATTGTCACTGTCC as forward and CAAGCTATTAATGTTATACATG as reverse primers and $\mathrm{pVA}_{7}$ as template the 3 'external probe "XbaI PCR probe" was obtained by PCR and has 490bp in length. The targeting vector was transferred into embryonic stem cells (E-14) via electroporation. Selection of transformants was done using Gentamycin 418®.

\subsubsection{Obtaining of Vti1b null mutants}

Isolated DNA of each transformed ES-cell clone was digested with EcoRI and loaded onto $0,7 \%$ agarose gels and southern-blots were obtained. Using DNA hybridisation techniques all clones were checked for homologous recombination with the "EcoRI-derived probe". The probe recognises a $4 \mathrm{~kb}$ wild-type EcoRI fragment and a 4,8kb mutant one because of the presence of an EcoRI site inside of the Neo-cassette. DNA of clones turned out to be positive (8) in that screening was checked for homologous recombination again using XbaI 
digestion. "XbaI PCR probe" detects an $8 \mathrm{~kb}$ wild-type XbaI fragment and a $7 \mathrm{~kb}$ recombinated one because of the presence of a $\mathrm{XbaI}$ site at the beginning of the coding region for the Neo-cassette.

7 clones were double positive out of 96 clones analysed (see fig. 9). These clones had homologous recombination in the Vti1b locus. Clones 114 and 177 were used for blastocyst microinjection.

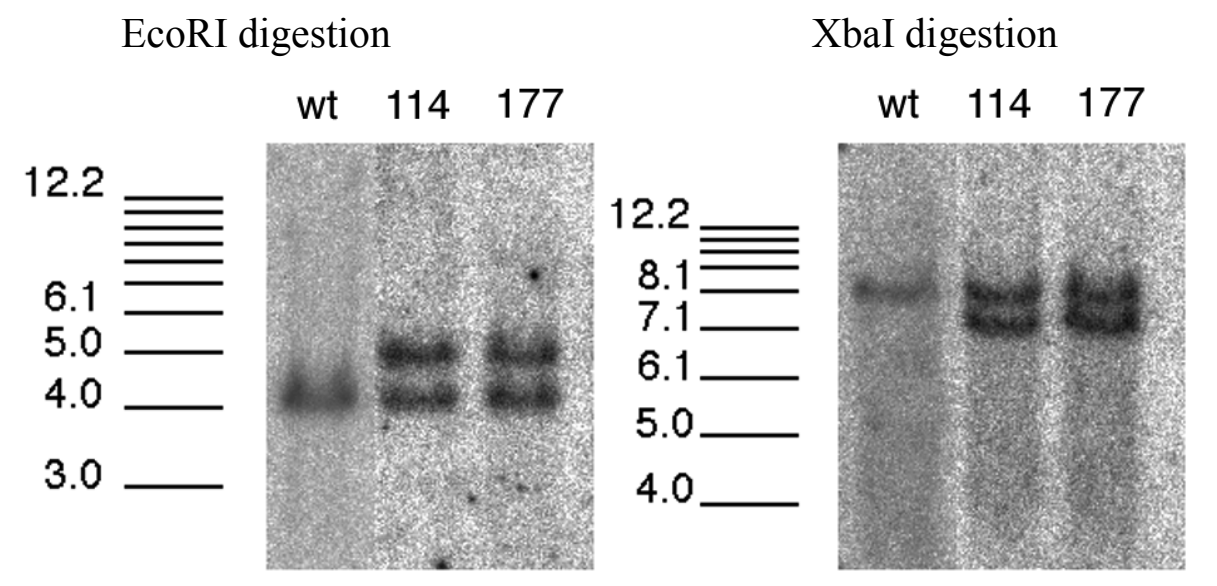

Figure 9: Analysis of ES mutant cells Clones 114 and 177 have one wild type and one mutant copy of Vtilb

Two male mice with 50-60\% of chimerism were obtained after injection of clone 114 . These chimeras were used for crossing with C57BL females to obtain F1 generation with mice heterozygote for the mutant Vtilb locus. To check for their genotype, a PCR strategy was developed (fig. 10). 
$100 \mathrm{bp}$
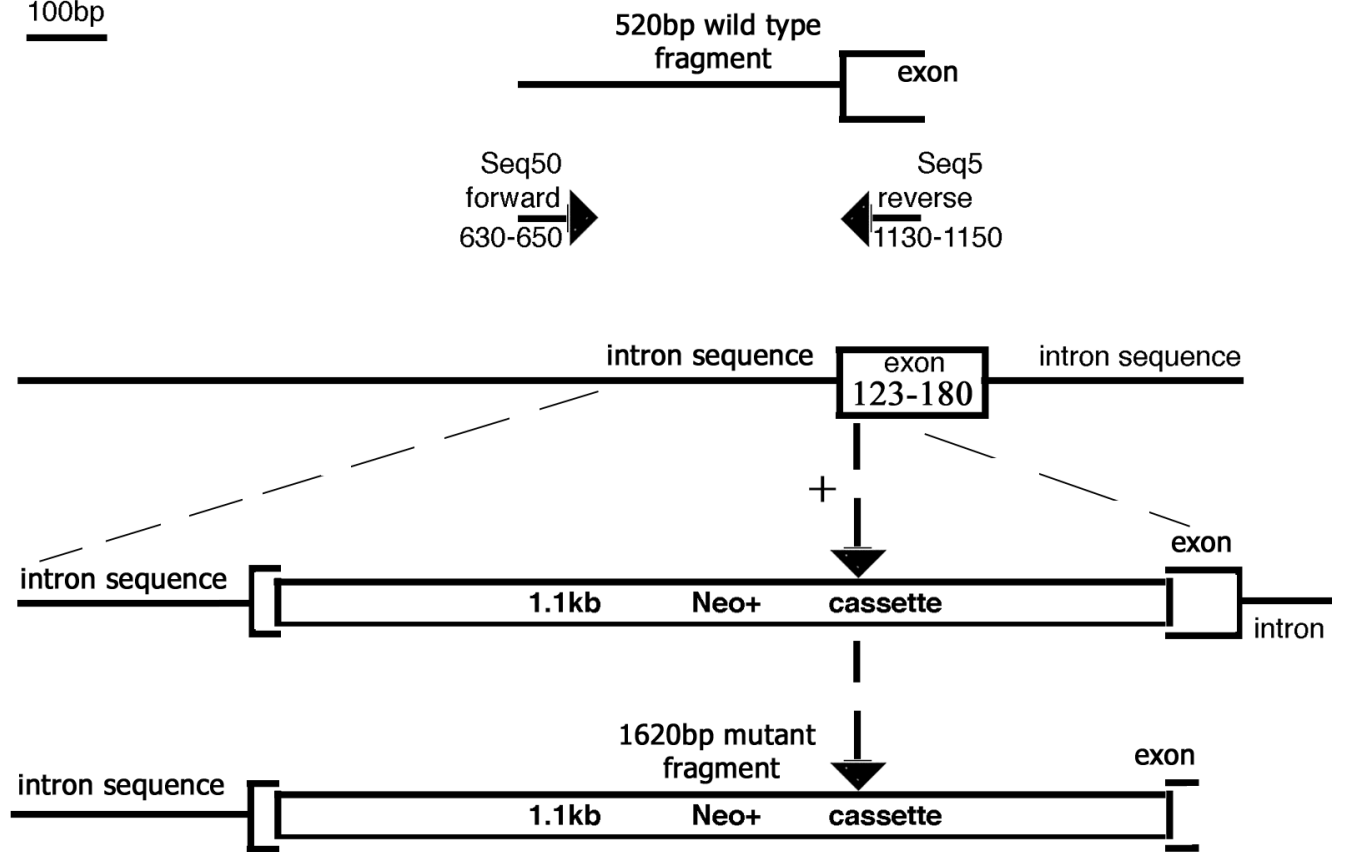

Figure 10: PCR strategy for determination of wild type and Vti1b mutant genotypes

Primers Seq5 and Seq50 (nucleotide sequences are CTCTTCTATGATTTCTGTACC and GAGGGATCCAATACCTTCTC respectively), amplifying a 520bp fragment of the wild type genomic region including exon 123-180 and a $1620 \mathrm{bp}$ fragment of the mutated Vtilb region were used for routine PCR analysis (fig.11). In addition, a 375bp fragment derived from the neo-gene was amplified using primers AK30 and AK31 (nucleotide sequences are CGGATCAAGCGTATGCAGCCG and CAAGATGGATTGCACGCAGG respectively).

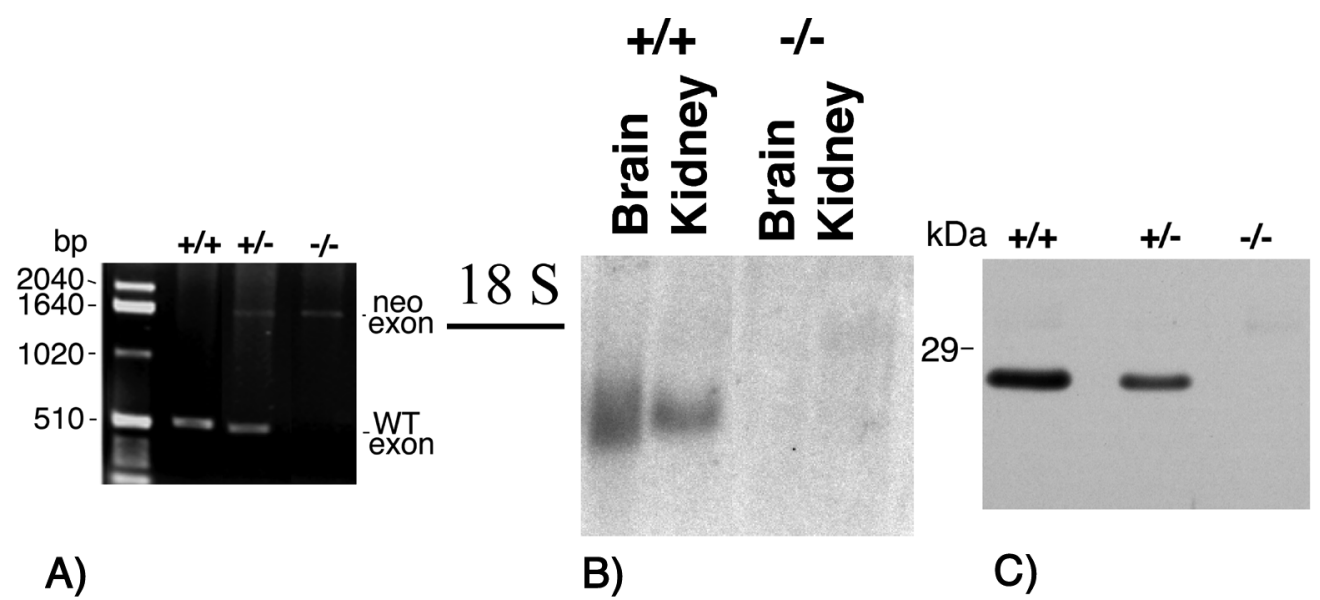

Figure 11: Vti1b mRNA and protein is missing in vti1b -/- cells

A) PCR analysis of genomic DNA using seq5 and seq50 oligos; B) nothern-blot analysis of Vtilb mRNA using probe "235"; C) western-blot analysis of MEF protein extracts using Vtilb antibodies 
After crossing of heterozygous F1 mice, homozygous mVtilb deficient mice were obtained.

Vtilb deficiency was inherited with almost mendelian distribution. 24,8\% wild type mice, $55,3 \%$ heterozygote and 19,9\% homozygote Vtilb deficient mice (expected would be $25 \%$ ) were detected among 226 mice from 24 litters. An interruption of exon "123-180" with the Neo-cassette resulted in total loss of Vtilb mRNA (fig 11). Moreover, a total loss of Vtilb protein was seen in deficient fibroblasts by western-blot with anti-Vtilb antibodies. Reduced levels of Vti1b protein was observed in heterozygous mice because of a gen-dosis effect (fig 11). 


\subsection{Analysis of Vti1b deficient mice}

\subsubsection{The phenotypic manifestation of Vti1b deficiency}

Vtilb deficient mice were viable and fertile. The phenotype of Vtilb deficient mice was heterogenous, there were mice of normal size and small ones (fig 12).

From 162 deficient mice 28 ones became small, that is $17,3 \%$. These mice were of normal size during the first two - three weeks after birth. At the age of 3 weeks (this period corresponds to changing from mother-milk to self-dependent feeding) these mice have a critical point of their life and some of them die (fig 13 A).
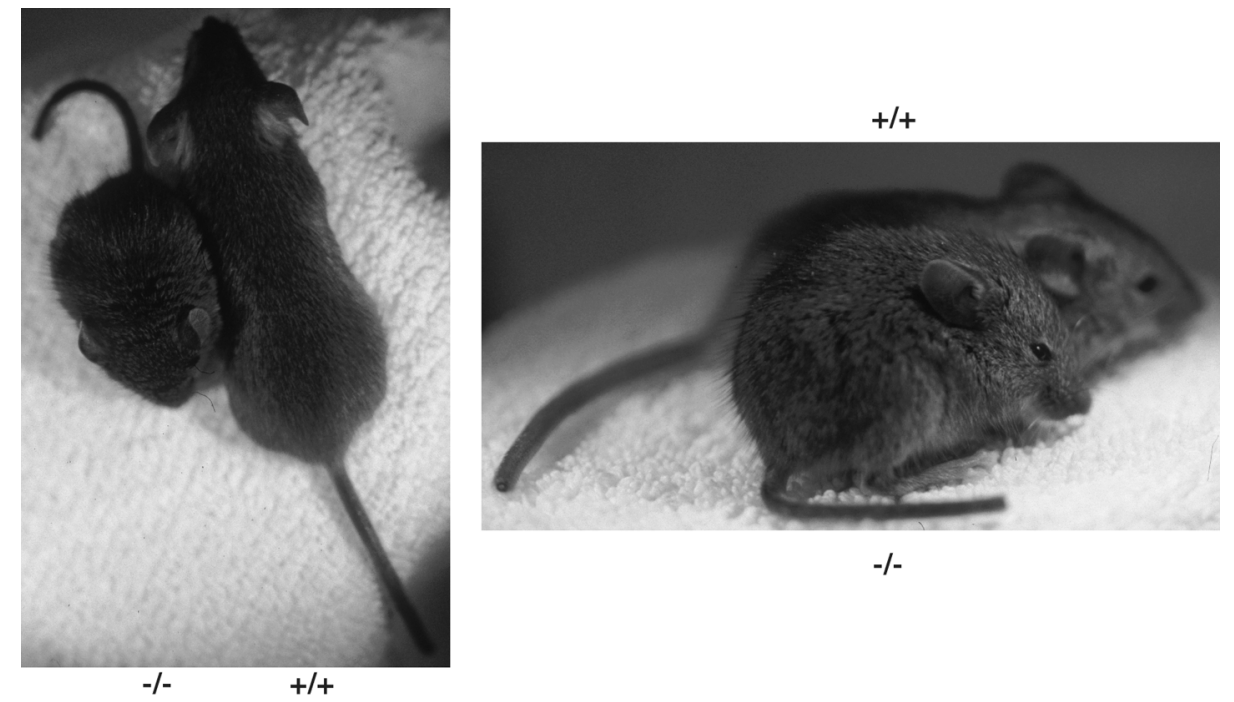

$-1-$

Figure 12: Some Vti1b deficient mice are smaller 
In that period 6 deficient mice died that is $3,7 \%$ of the Vtilb knock-outs. Altogether, one newborn and 8 small Vtilb knock out mice were found dead after different periods of postnatal development. Some mice lost weight in that time period and stayed smaller than their litter mates(fig $13 \mathrm{~B}$ ). The small mice were fertile and had both small and normal size descendants.

Some Vtilb deficient mice had different pathologies of internal organs. Three small knockout mice had abnormally big gallbladders (fig 14 ). One of them had an obsruction of the colon. One small deficient mouse had multiple liver cysts, of up to $3 \mathrm{~cm}$ of size. One deficient mouse of normal size had gall stones. Another -/- mouse of normal size was killed at an age of 16 months because it looked sick.
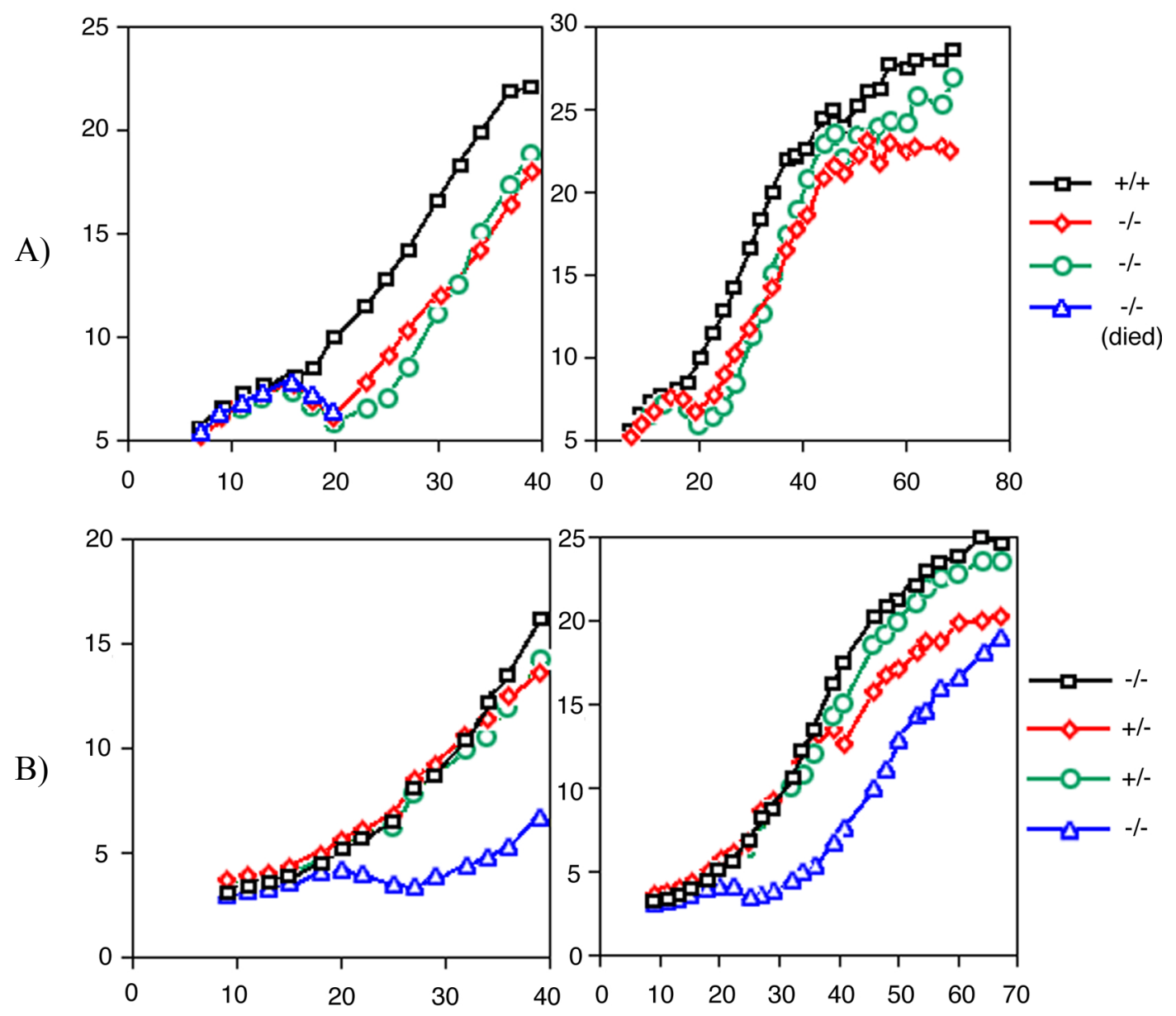

Figure 13: Growth of Vtilb litter/mates

$\mathrm{X}$ axis represents age in days, $\mathrm{Y}$ axis - weight in grams. A) Some small Vtilb deficient mice die when they are 3 weeks old. B) Development of surviving small mouse. 


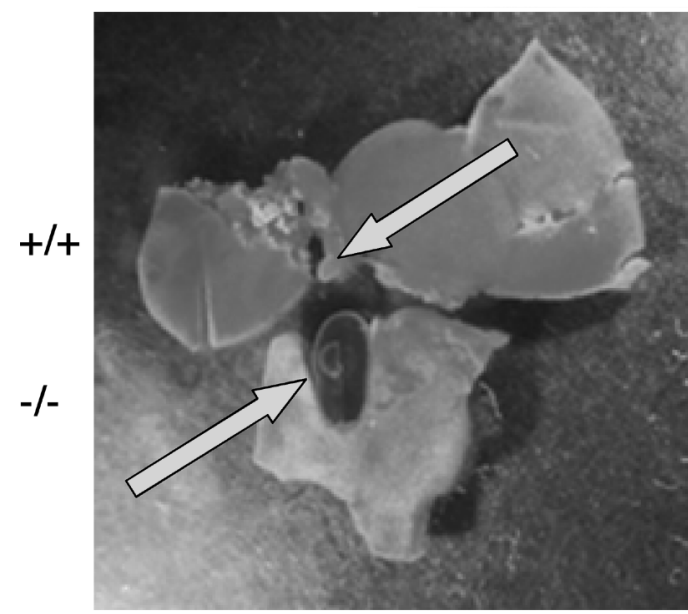

A)

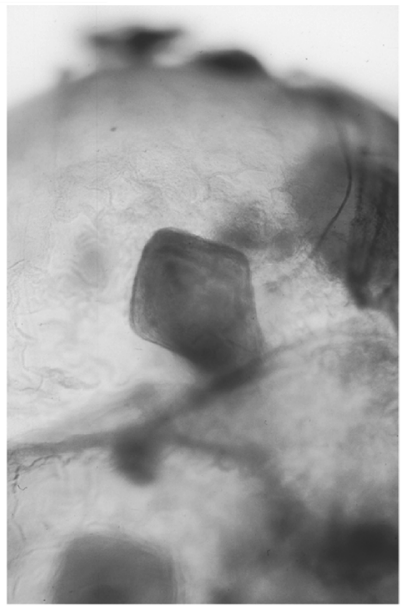

B)

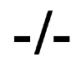

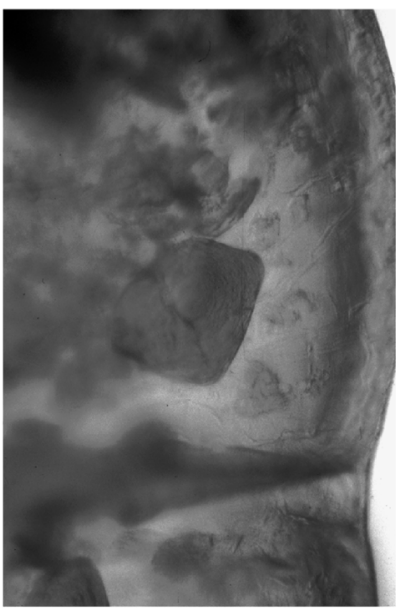

C)
$-/-$

Figure 14: Gallbladder abnormalities in a few Vti1b deficient mice

A) Arrows (left) indicate gallbladder of wild type and Vti1b knockout mouse; B) and C) Gall stones of normal size Vtilb deficient mouse

It had an abnormally shaped gallbladder, splenomegaly and the stomach, appendix, intestines were abnormally enlarged and filled. No wild-type mice examined in parallel had any visible pathologies.

\subsubsection{Immunofluorescent localisation of different proteins in mouse embryonic fibroblasts}

Mouse embryonic fibroblasts (MEF) were obtained from embryos of day 13,5.

Experiments were started after 4 passages. Morphologically Vtilb deficient fibroblasts were indistinguishable from wild type MEFs. Both cell types reached confluency at similar rates. To check if the patterns of distribution of several SNAREs, lysosomal and receptor proteins were changed in knock-out cells, immunofluorescent microscopy was performed. Vtilb in control cells was localized to the perinuclear area and extended into the periphery of the cell. No Vtilb staining was observed in deficient cells (fig 15 B). 


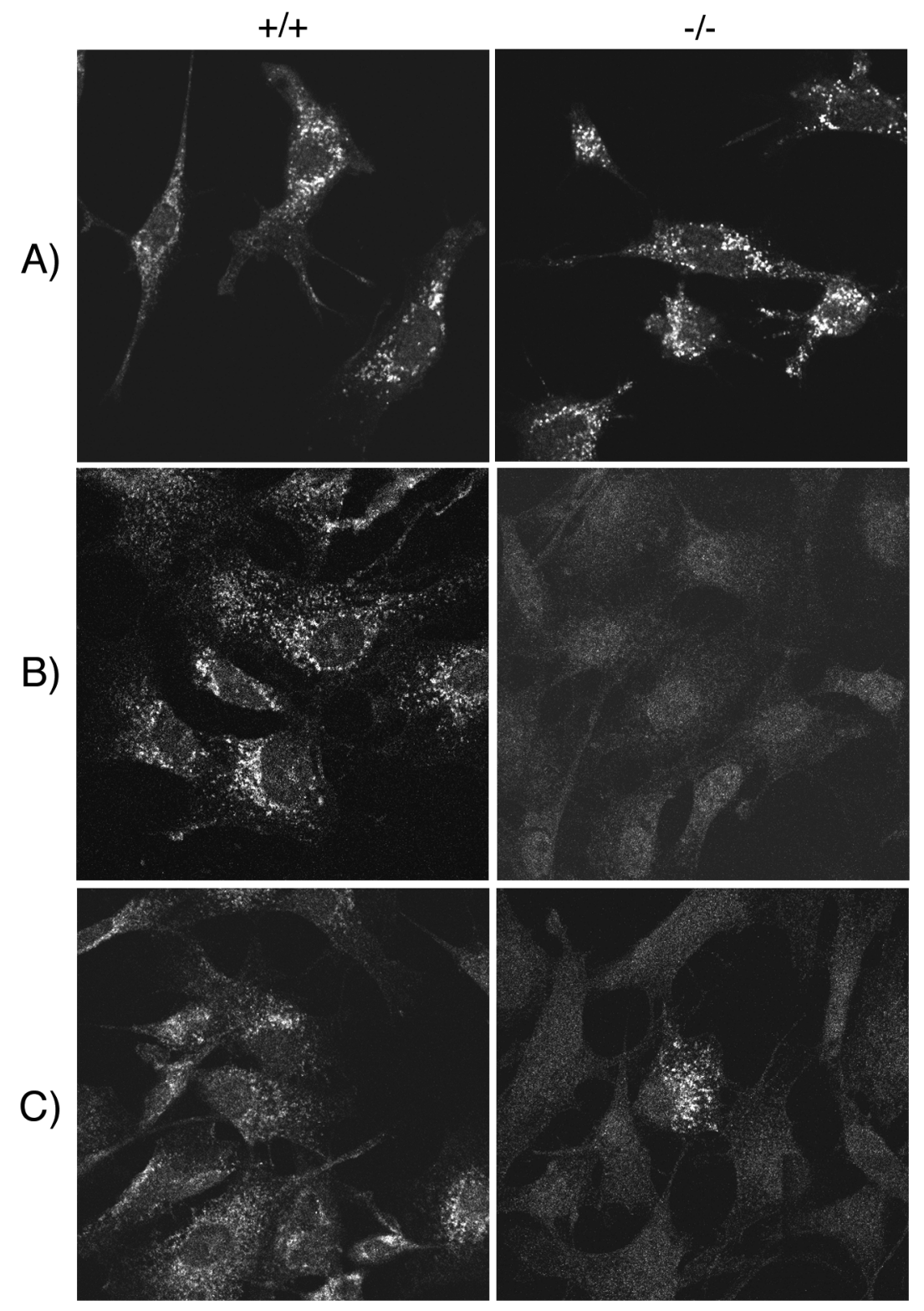

\section{Figure 15: Immunofluorescent localisation of LIMPII, Vti1b and syntaxin 8 in wild type and Vtilb deficient MEF}

A) Similar distribution of LIMPII; B) Vtilb staining in wild type cells and no signal in Vtilb knockout MEF ;C) Low levels of syntaxin-8 in Vtilb -/- embryonic fibroblasts

Vtila was found on perinuclear structures in both cell types compared (not shown). MPR-

46 antibodies stained parinuclear area and many vesicular structures throughout cytoplasm. LAMP1, LAMP2, LIMPII showed similar patterns marking distributed vesicular structures. Vti1a, LAMP1, LAMP2, LIMPII and MPR-46 showed distributions in Vtilb -/- 
cells very similar to that of wild type cells. Figure 15 A) illustrates the similar staining for LIMPII indicating that lysosomal morphology is not affected in Vtilb -/- MEF.

By contrast, syntaxin- 8 had low levels of fluorescent staining in deficient MEFs. Figure $15 \mathrm{C}$ ) shows staining of Vtilb deficient and wild type cells with syntaxin-8 antibodies. As syntaxin-8 forms a SNARE complex with Vtilb this indicates that the absence of Vtilb may destabilise its SNARE partner.

\subsubsection{Immunofluorescent localisation of different proteins in cultivated hepatocytes}

Hepatocytes of normal size Vtilb deficient and wild type mice were cultivated for one day and also used for localisation of several proteins using different antibodies (Fig16)

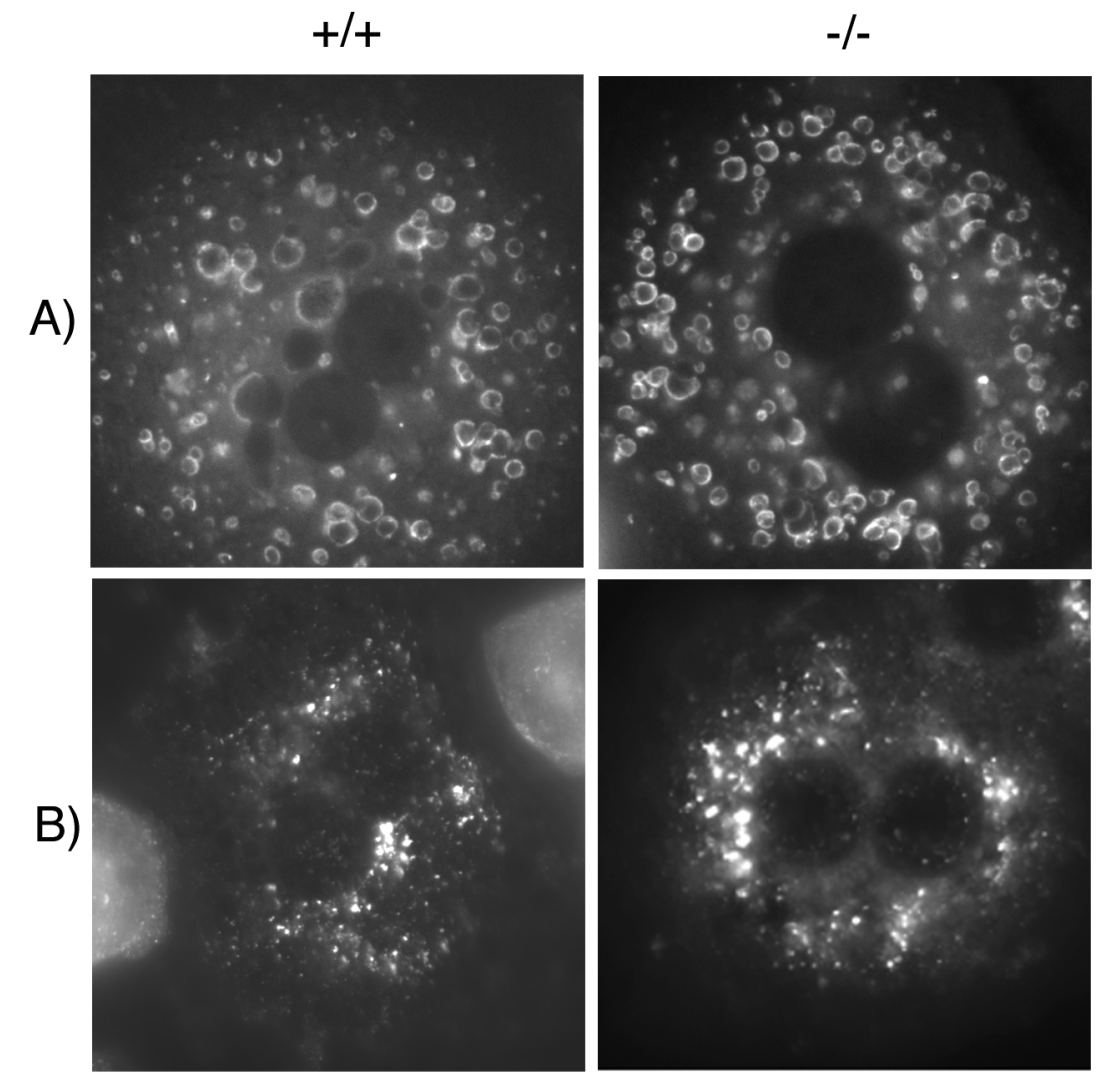

Figure 16: Localisation of adipophilin and MPR-46 in hepatocytes isolated from wild type and normal size Vtilb deficient mice A) Staining with anti-adipophilin antibodies; B) Staining with anti- mannose 6-phosphate receptor antibodies

LAMP1, LAMP2 containing structures were stained similarly (fig 17 B) or were slightly enlarged in cells of Vtilb -/- mice. The soluble lysosomal hydrolase cathepsin D (fig $17 \mathrm{~A}$ ) 
colocalised with LAMP1 and LAMP2 in both -/- and +/+ hepatocytes (not shown). MPR46 and LAMP1 did not colocalise with each other (not shown).

A)
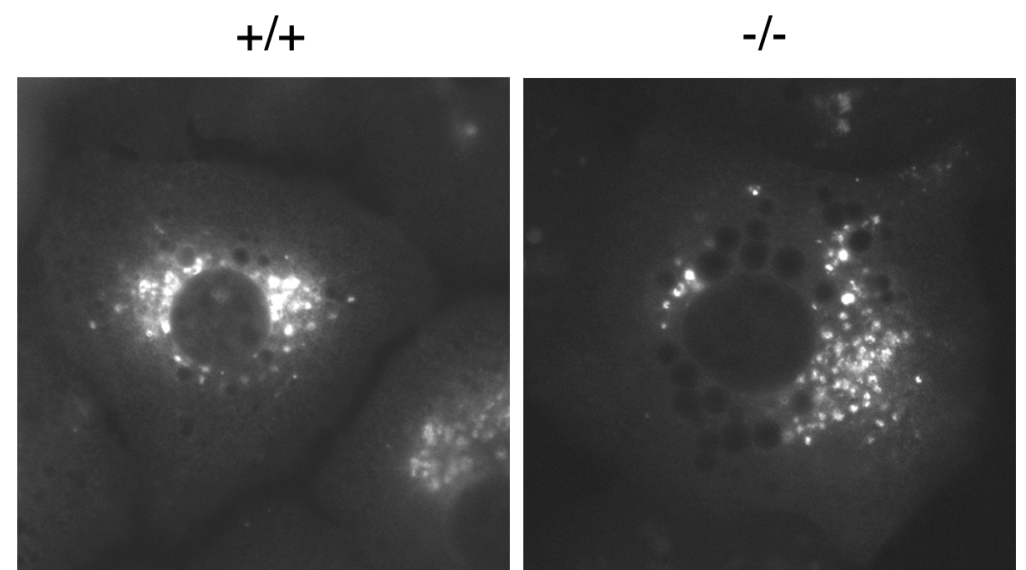

B)
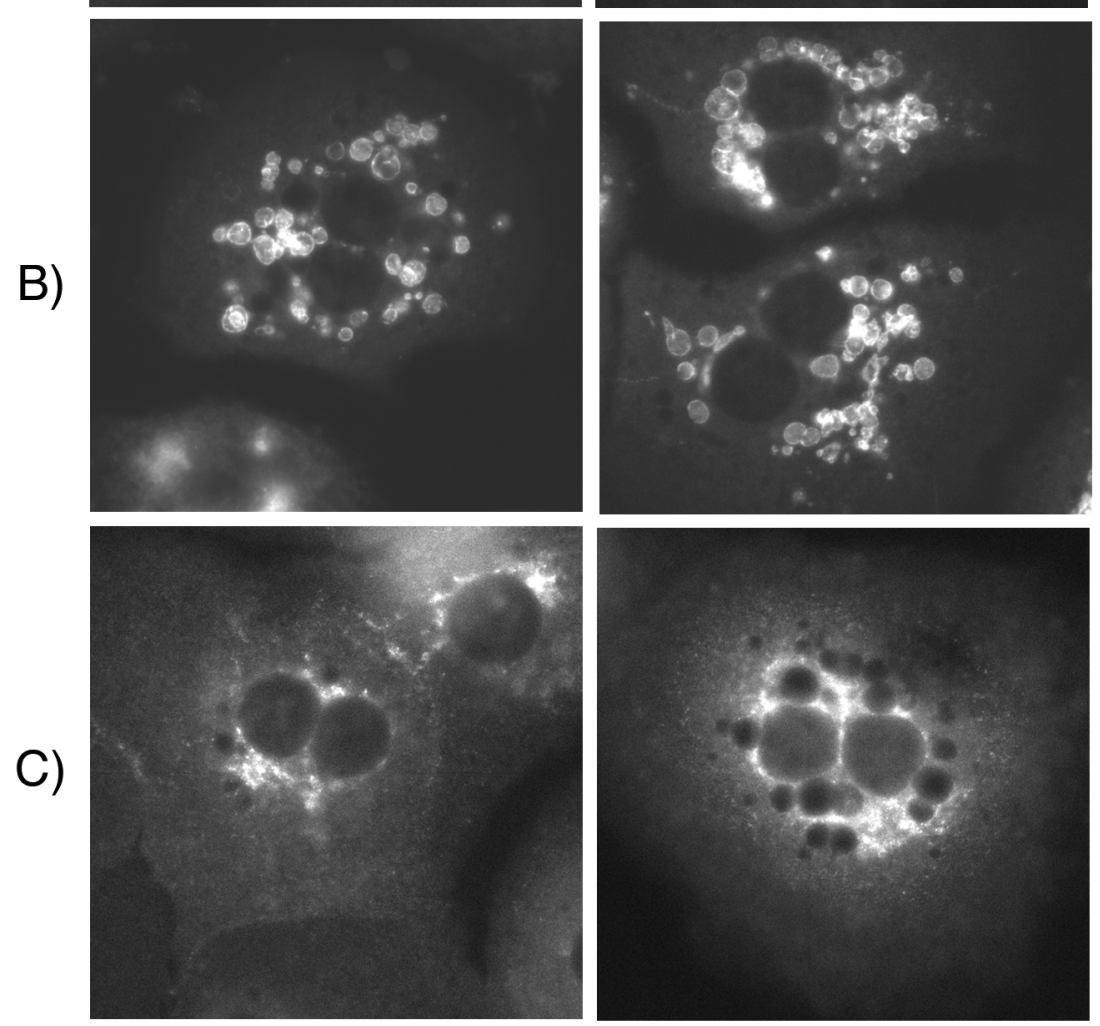

Figure 17: Localisation of cathepsin D, LAMP1 and $\gamma$ adaptin in hepatocytes isolated from wild type and normal size Vti1b deficient mice A) Cathepsin D antibodies; B) LAMP1 antibodies; C) $\gamma$-adaptin antibodies

Similar distribution of the TGN protein $\gamma$-adaptin was seen in cells of both genotypes (fig $17 \mathrm{C})$. The number and size of lipid droplets which were stained by neutral lipid dye nile red or by adipophilin (fig $16 \mathrm{~A}$ ), a marker protein of lipid-containing vesicles, had 
probably no connection to the absence of Vtilb and was dependent on stored body fat. The more fat mice had on their internal organs, the more and bigger structures stained with adipophilin antibodies were seen in cells of both genotypes. The absence of Vti1b did not alter distribution of the examined lysosomal, TGN and late endosomal proteins in hepatocytes of normal size Vtilb deficient mice.

\subsubsection{Activities of lysosomal enzymes in serum and organs of these mice}

Activities of lysosomal hydrolases were determined in serum and organe homogenates of control and Vtilb deficient mice. Calculation of these activities in blood serum is shown in table 7:

\begin{tabular}{|c|c|c|}
\hline \multirow{2}{*}{$\begin{array}{l}\text { Lysosomal } \\
\text { enzyme }\end{array}$} & \multicolumn{2}{|c|}{ Activity, mU/ml } \\
\hline & $\begin{array}{l}\text { Deficient mice } \\
\qquad \mathrm{n}=4\end{array}$ & $\begin{array}{c}\text { Control mice } \\
n=2\end{array}$ \\
\hline ß-Hexosaminidase & $62,9 \pm 16,8$ & $61,9 \pm 5,1$ \\
\hline ß- Galactosidase & $0,5 \pm 0,1$ & $0,6 \pm 0,1$ \\
\hline ß-Mannosidase & $2,4 \pm 0,7$ & $1,4 \pm 0,6$ \\
\hline ß-Glucuronidase & $0,6 \pm 0,3$ & $0,6 \pm 0,3$ \\
\hline
\end{tabular}

Numbers show average values \pm standard deviation.

Activities of lysosomal hydrolases were measured in liver, brain, kidney and spleen homogenates at an age of 3 - 9 months. The activities were very variable for all analysed enzymes even within wild type mice. 

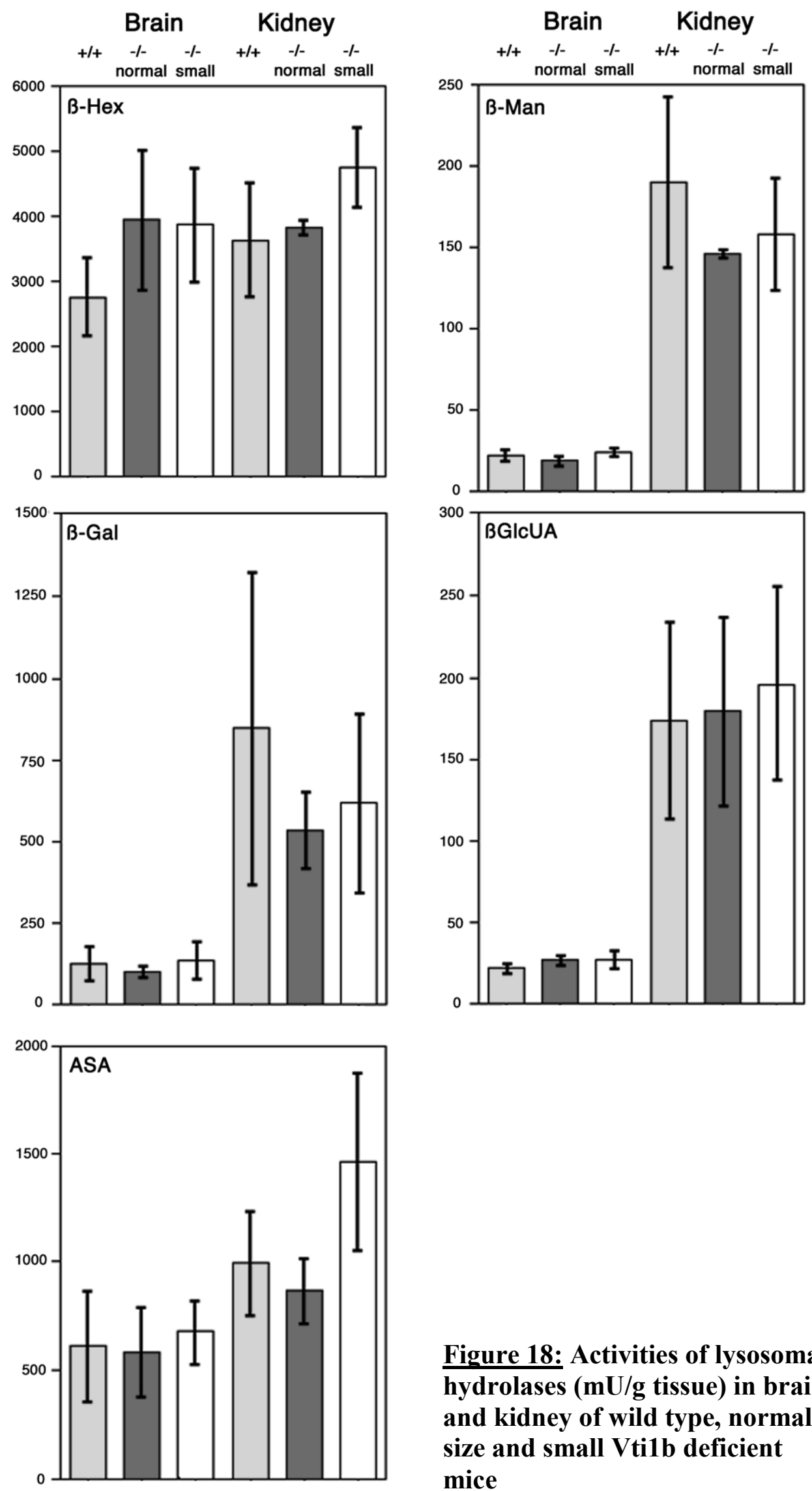

Figure 18: Activities of lysosomal hydrolases ( $\mathrm{mU} / \mathrm{g}$ tissue) in brain and kidney of wild type, normal size and small Vti1b deficient mice 
Figure 18 shows that in brain and kidney activities of $\beta$-Hexosaminidase ( $\beta$-Hex), $\beta$ Mannosidase (ß-Man), ß-Glucuronidase (ß-GlcUA) and Arylsulfatase A (ASA) in Vtilb deficient mice in general stay within limits of control values.In liver and spleen activities of lysosomal enzymes also stay within limits of control values in case of normal size and small deficient mice. In a single case, lower $\beta$-Galactosidase activity of $118 \mathrm{mU} / \mathrm{g}$ in a liver of small Vtilb deficient mouse could be seen. The average control value for $\beta-$ galactosidase in liver was $293 \pm 133 \mathrm{mU} / \mathrm{g}$, the activity of $\beta$-galactosidase in liver of normal size knock-out mice was $300 \pm 229 \mathrm{mU} / \mathrm{g}$. The activities of lysosomal enzymes did not increase or decrease significantly during lifetime of knock-out mice, as seen in Vtilb deficient and wild type analysed at an age of 9 months. MEF homogenates also showed very similar pattern of activities.

\subsubsection{Levels of several proteins in Vti1b deficient cells and tissues}

Expression of several proteins was compared in control and deficient cells and tissues to determine whether Vtilb deficiency had an influence on lysosomal and receptor protein levels. Cultivated MEFs and hepatocytes were homogenised and protein suspensions were separated using SDS-PAGE. The same was done for tissue homogenates.

LAMP1, LAMP2, LIMPII are equally abundant in cultivated MEFs as well as in liver, brain and kidney of control and Vtilb deficient mice. There was no obvious difference in the amount of these proteins in tissues between control, normal size knock-out mice and small knock-out mice (fig19). 


\begin{tabular}{llll} 
Liver & \multicolumn{2}{c}{ Brain } & \multicolumn{2}{c}{ Kidney } \\
+ & $\frac{1}{+}+\frac{1}{+}$ & $\frac{1}{+}$ & $\frac{1}{+}$
\end{tabular}

\section{7kDa}

A)

\section{7ka}

B)

\section{7kDa}

C)

D)

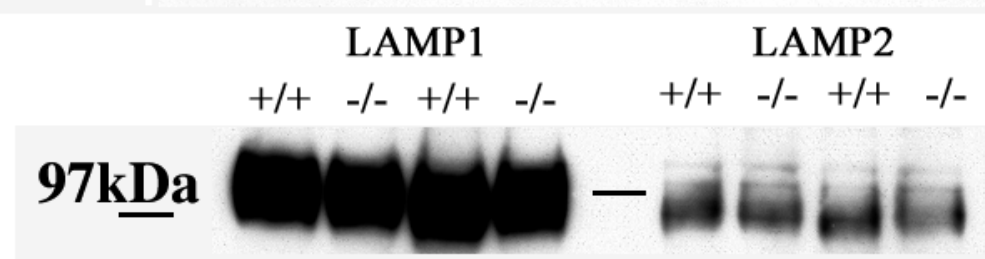

Figure 19: Levels of lysosomal proteins in control, heterozygote and Vti1b deficient tissues and MEFs A)LAMP1 antibodies used; B)LAMP2 antibodies used; C)LIMPII antibodies used; D) Levels of lysosomal proteins in wild type and Vtilb deficient MEFs

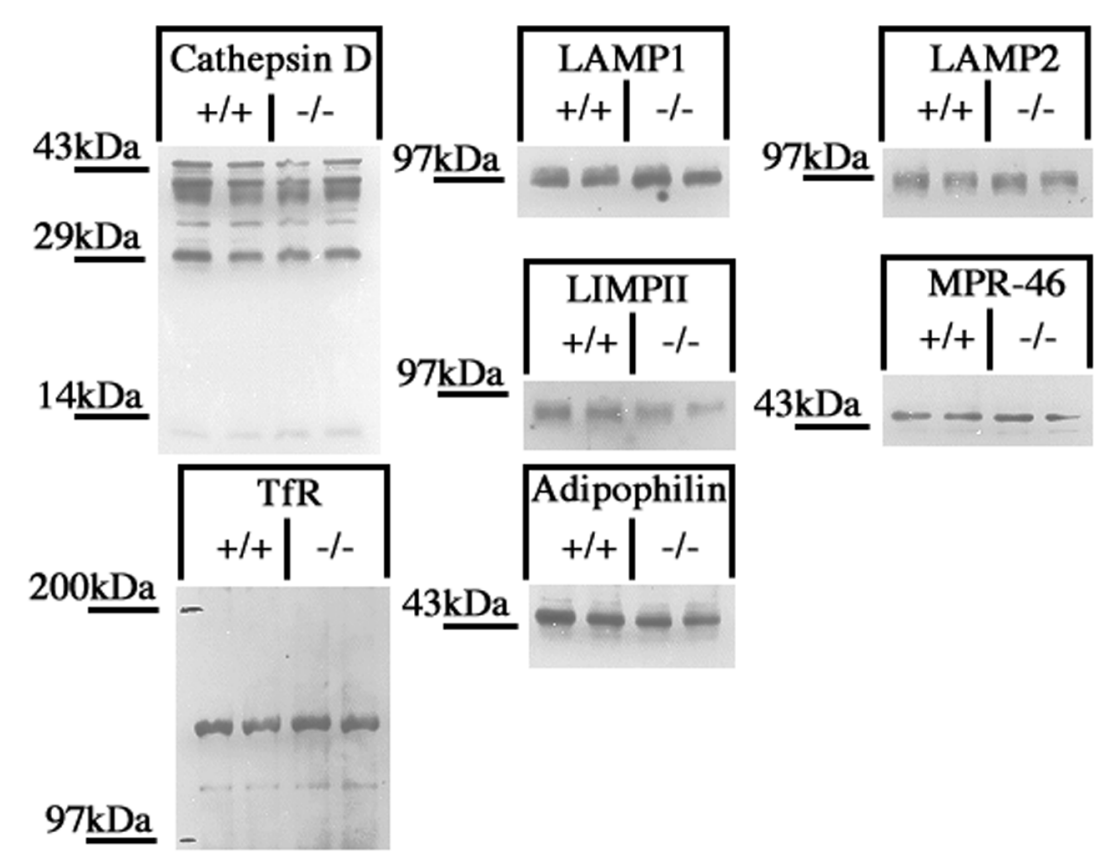

Figure 20: Analysis of the amounts of several lysosomal and receptor proteins in control and Vtilb deficient hepatocytes from normal size mice 
The lysosomal proteins cathepsin D, LAMP1, LAMP2, LIMPII were equally abundant in wild type and Vtilb deficient hepatocytes. The same could be observed for MPR-46, transferrin receptor (TfR) and adipophilin, a marker protein of lipid droplets (fig 20). In summary Vtilb deficiency had no obvious effect on the levels of the analysed proteins in cells isolated from normal size mice.

\subsubsection{Syntaxin 8 and other SNAREs expression in Vti1b deficient cells and tissues}

Syntaxin 8 is a SNARE partner of Vtilb in a SNARE complex mediating fusion of late endosomes together with syntaxin 7 and endobrevin (Antonin et al. 2000a). The first indication that syntaxin 8 levels were affected in Vtilb deficient cells came from the immunofluorescence (4.1.5). In Vtilb deficient MEFs only a few cells showed a fluorescent signal after staining them with anti-syntaxin 8 antibodies (see fig.15C). The levels of the Vtilb SNARE partners were examined in control and Vtilb deficient tissue homogenates. Figure 21 shows that syntaxin 7 and endobrevin had amounts similar to control in Vtilb deficient tissues. On the contrary amounts of syntaxin 8 were reduced already in Vtilb heterozygous tissues. Vtilb deficient tissues had much less syntaxin 8 than Vtilb heterozygous tissues and of course wild type ones (fig 21). These results were in agreement with data of the immunofluorescence.

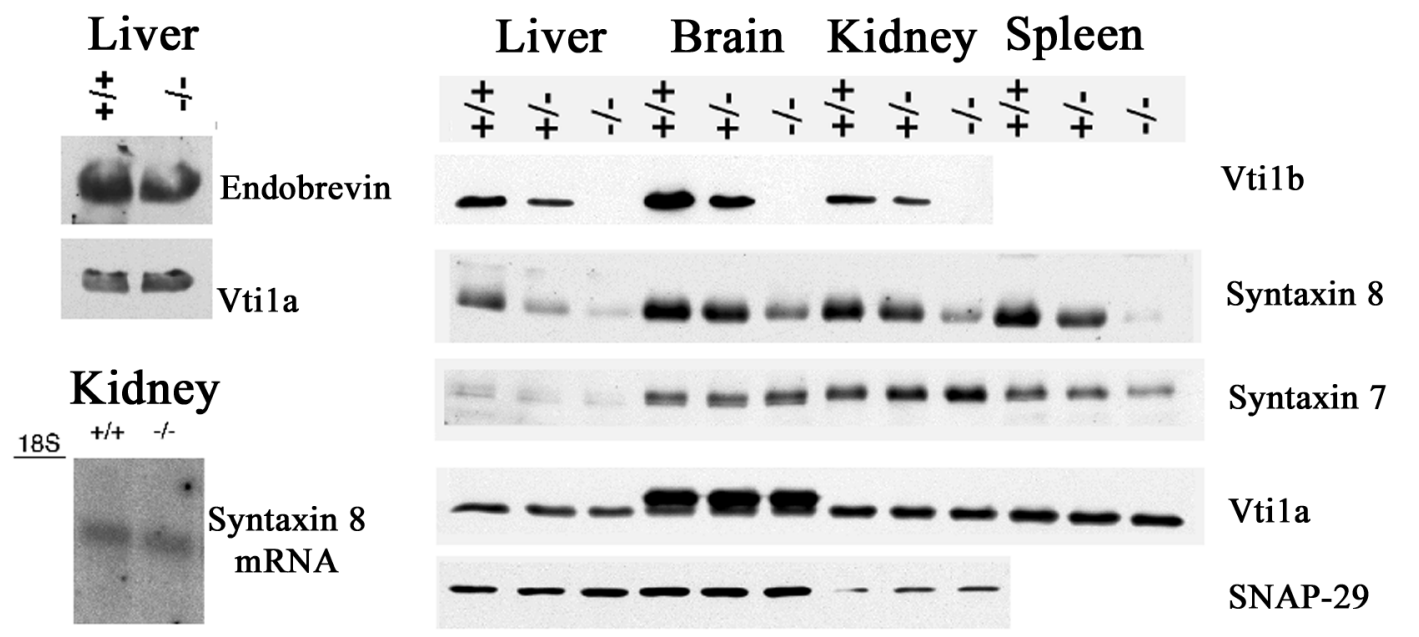

Figure 21: Levels of SNARE proteins in wild type, heterozygote and Vti1b deficient mice

Syntaxin 8 was a very long-lived protein. Even though syntaxin 8 could be immunoprecipitated the radioactive labelled form was not visible even after $4 \mathrm{~h}$ in vivo labelling with $\left[{ }^{35} \mathrm{~S}\right]$-methionine (not shown). Expression of syntaxin 8 mRNA was 
unchanged in Vtilb deficient tissues (fig 21) compared to wild type tissues. Therefore a possible explanation for the low syntaxin 8 protein levels would be that the protein is degraded due to the absence of its complex partner Vtilb.

Vti1b deficient mice are viable and fertile. Most of these mice show no visible abnormalities in their postnatal development. An explanation for this lack of phenotype could be that some SNARE or SNAREs fulfil the function of the absent Vtilb and the reduced syntaxin 8 in tissues of knock-out mice. As Vtilb and Vtila are homologes, the expression of Vtila was checked in control and knock-out tissues. A second candidate for overtaking the functions of both Vtilb and syntaxin 8 in the late endosomal SNARE complex is SNAP-29, which has two SNARE motifs. Its expression was also checked in both control and knock-out mice. Results are shown in figure 21. The levels of these proteins stayed similar to control in deficient tissues. There was no visible difference in the amounts of Vtila and SNAP-29 in control, normal size (not shown) and small Vti1b deficient tissues (figure 21). However this does not exclude their possible role in a functional compensation for Vtilb and syntaxin 8 deficiency.

\subsubsection{Fluid-phase endocytosis in control and deficient MEFs}

In order to get a deeper insight into fluid phase endocytosis along the endosomal/lysosomal apparatus in MEFs, the fate of internalised fluorescein isothiocyanate-labeled dextran (FITC-dextran) during constitutive fluid-phase endocytosis was studied. This fluid-phase and $\mathrm{pH}$ marker is taken up by cells without being absorbed to membranes and is not degraded inside lysosomes ((Thilo and Vogel 1980; de_Chastellier et al. 1983; Klein and Satre 1986). The fluid-phase internalisation is partially clathrin-mediated. Clathrin heavy chain-deficient mutants of amoeba Dictyostelium discoideum had a 90\% reduced fluidphase endocytosis activity (O_Halloran and Anderson 1992). Constitutive fluid-phase endocytosis (pinocytosis) has attracted less attention although most cell types are capable of internalizing quite large volumes of medium by this pathway (Steinman et al. 1983) in a clathrin independent way. 


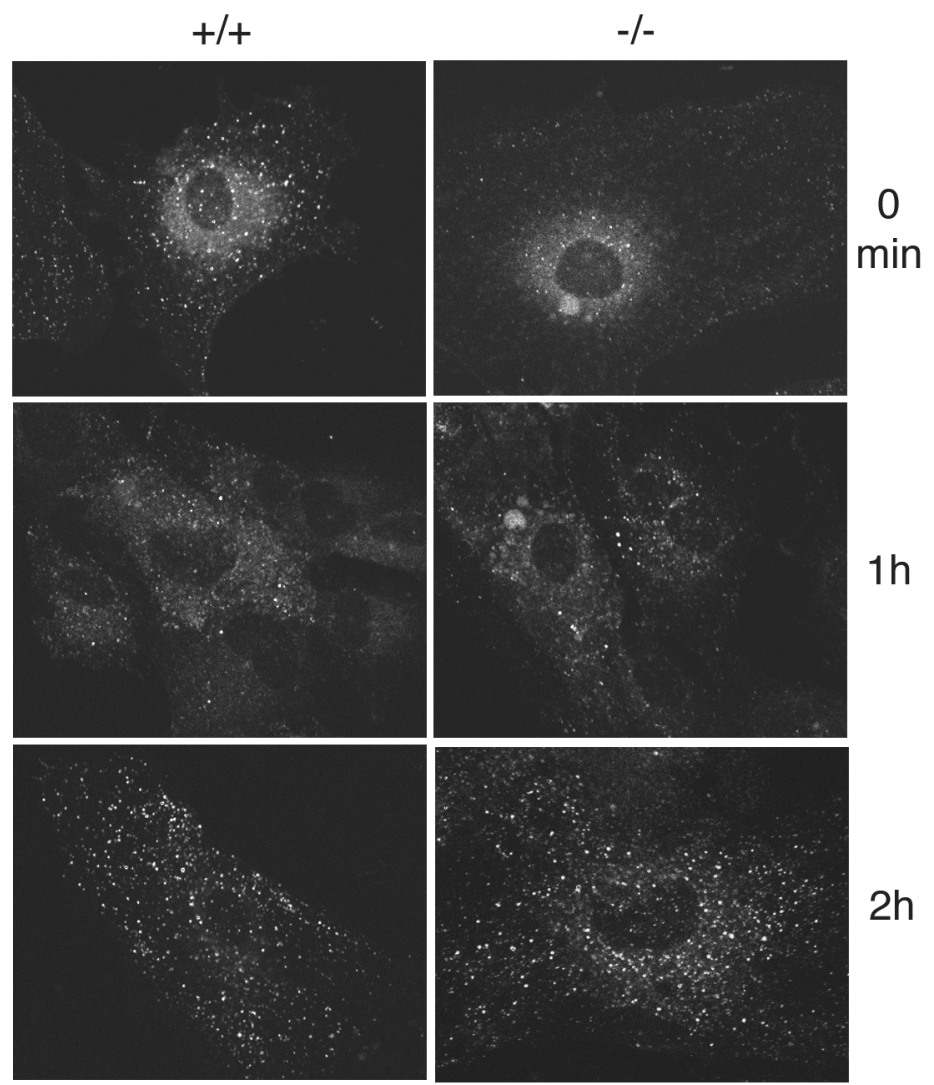

\section{Figure 22: FITC-dextran uptake by control and Vti1b knock-out MEFs}

Cells were grown on coverslips till they reached confluency. To stimulate uptake, cells were incubated in serum-free medium for $1 \mathrm{~h}$. Afterwards $200 \mu \mathrm{l} \mathrm{FITC-dextran}$ $(\mathrm{MW}=14000)$ solution $(2 \mathrm{mg} / \mathrm{ml})$ in medium was added for $1 \mathrm{~h}$ (pulse). Cells were washed with PBS and incubated for chosen chase periods of $0 \mathrm{~min}, 1 \mathrm{~h}$ and $2 \mathrm{~h}$ with fresh medium. Figure 22 shows that control and Vtilb deficient cells internalised FITC-dextran in a similar way. There was no retardation of the uptake of FITC-dextran into endosomes in deficient fibroblasts (0min). After 1h FITC dextran reached lysosomes and accumulated there ( $2 \mathrm{~h}$ chase). There was no visible differences in its accumulation between control and Vtilb knock-out MEFs. These data indicate that fluid-phase endocytosis and transport to lysosomes was not affected enough in Vtilb deficient cells to produce an obvious defect in this microscopical assay. 


\subsubsection{Fluorescent-LDL uptake and degradation in control and knock- out MEFs}

Lysosomal degradation of ligands following receptor mediated endocytosis via clathrin coated vesicles is a major pathway. Examples for ligands are asialoglycoproteins, epidermal growth factor (Dunn and Hubbard 1984), and low-density lipoproteins, LDL (Anderson et al. 1976). LDL receptors are found on nearly all human and animal cells (Brown and Goldstein 1976). The LDL-receptor pathway is a model for receptors which participate in receptor-mediated endocytosis and are reutilized or recycled, thus allowing each receptor molecule to deliver many ligands to their ultimate destination through multiple rounds of endocytosis. It is recycled very efficiently since each LDL receptor can internalize more than 150 LDL particles during its 30-hour life-span (Brown et al. 1982). Cells were washed twice with PBS to remove dead ones and FKS from the medium and incubated with serum-free medium for a time period of $2 \mathrm{~h}$ (starvation). Starvation medium was then replaced with fluorescently labeled low-density-lipoprotein $(10 \mu \mathrm{g} / \mathrm{ml}$, BODIPY ${ }^{\circledR}$, Molecular Probes, USA) in starvation medium and cells were put on ice for 90 min (receptor binding). Cells were washed with PBS at room temperature twice and incubated for several chase periods.

Control and Vtilb deficient cells internalised and processed fluorescently-labelled LDL in a similar way (fig 23). There was no retardation of the uptake of labelled-LDL into endosomes in Vtilb deficient fibroblasts (30min). After $1 \mathrm{~h}$ LDL reached lysosomes and accumulated there, starting to degrade. 

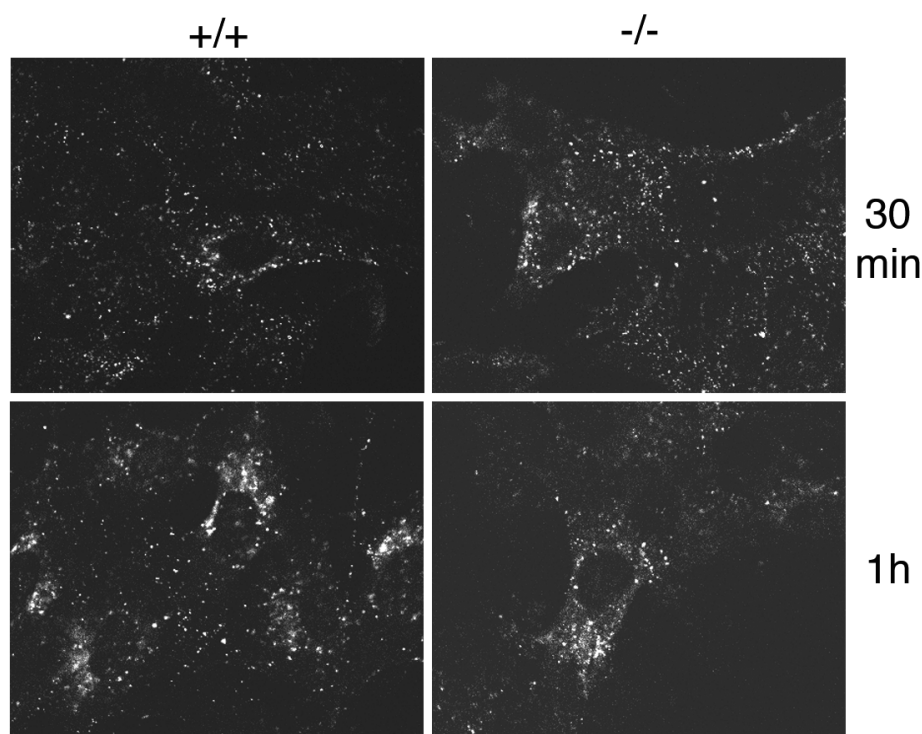

30

$\min$
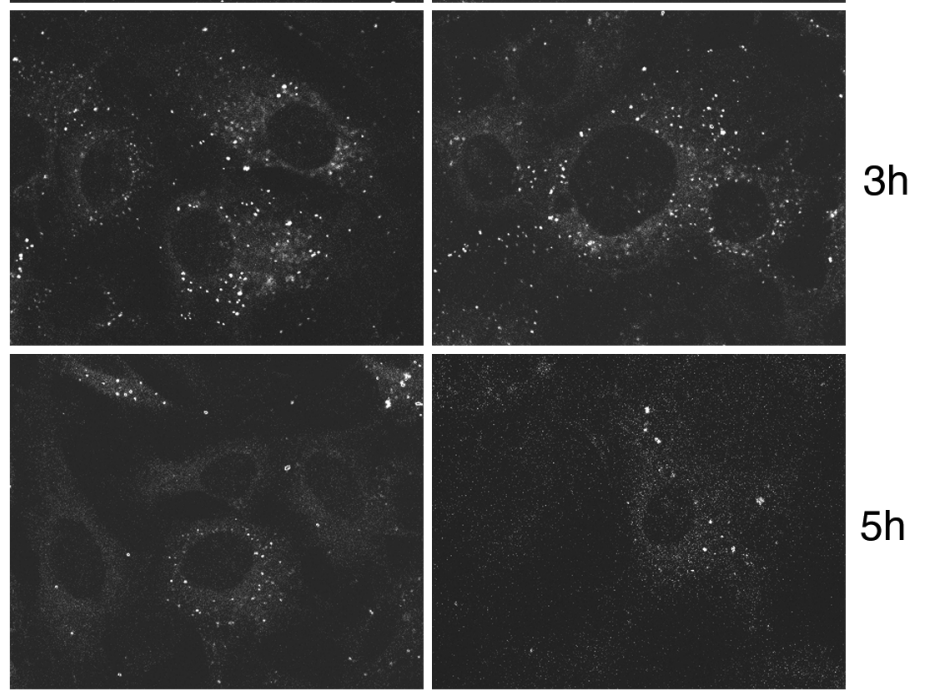

$1 \mathrm{~h}$

$5 \mathrm{~h}$

\section{Figure 23: Fluorescent LDL uptake and degradation in control and knock-out MEFs}

There was no visible differences in its degradation between control and knock-out MEFs (3h chase). After $5 \mathrm{~h}$ chase almost all internalised LDL was degraded in both cell types. These data indicate that Vtilb deficiency has no visible effect on LDL traffic in MEF cells in this microscopical assay.

\subsubsection{EGF-R uptake and degradation in Vti1b deficient hepatocytes}

Epidermal growth factor (EGF) is known to bind its receptor, EGF-R at the plasma membrane and to induce endocytosis of the complex. The receptor and EGF are then transported to lysosomes for degradation. EGF-R typically recycles through the early endosome back to the plasma membrane an estimated 3-5 times before it is selected for degradation in a stochastic manner by transport via the late endosomal compartments. At 
steady state, $70-80 \%$ of the EGF-occupied EGF-R is endosomal (Sorkin et al. 1988). Using antibodies directed against EGF-R the rates of ligand induced receptor degradation can be compared after different chase periods.

Mouse hepatocytes were isolated using a collagenase-independent method and Percoll ${ }^{\circledR}$ density gradient centrifugation as described under 3.3.1.4 and cultivated overnight in RPMI medium supplemented with $10 \%$ FKS. Isolated hepatocytes were starved for $2 \mathrm{~h}$ in serum-free medium. Two plates of each type were put on ice and cells were collected (0min). To the other plates $100 \mathrm{ng} / \mathrm{ml}$ purified EGF in serum-free medium was added followed by an incubation for $4 \mathrm{~h}$. Cells were scraped off in $200 \mu \mathrm{l}$ of $0,1 \%$ TritonX-100 in TBS, sonicated and protein concentration was determined. $100 \mu \mathrm{g}$ total protein of the obtained homogenate per lane was separated using 5\% SDS-PAGE followed by westernblotting. EGF-R was detected in western-blots by antibodies using an ECL-detection assay. Pictures were taken with an luminiscent image analyser and AIDA software was used for quantification of blots. An average amount of EGF-R in homogenates obtained from cells without EGF addition was used as $100 \%$.

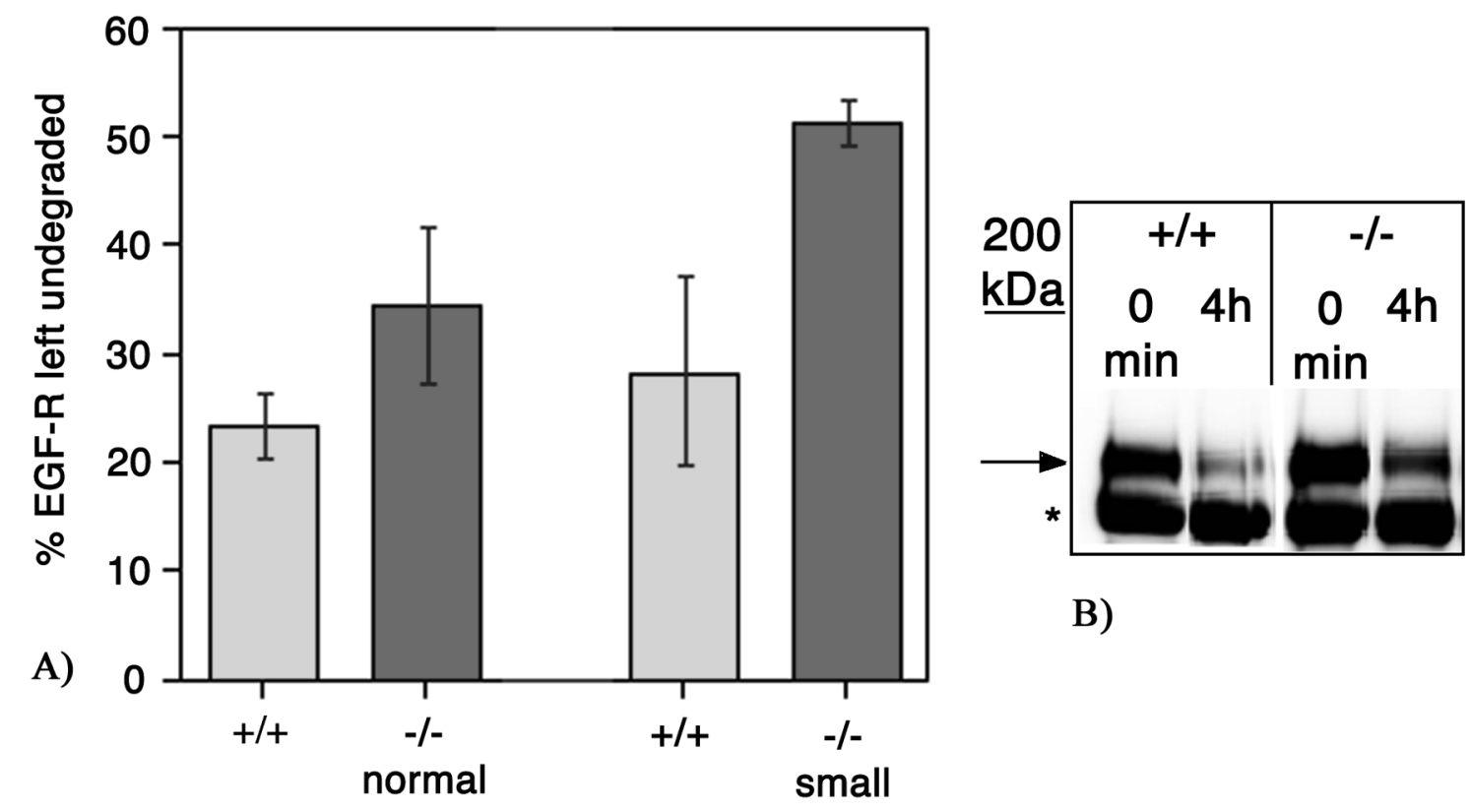

Figure 24: EGF-R degradation after $4 \mathrm{~h}$ in control and knockout Vti1b hepatocytes

A) Quantitative comparison; B) Original western-blot data; An arrow shows EGF-R band, an asterisk non-specific band ; -/- is small mouse N33

After $4 \mathrm{~h} 23,3 \pm 3,5 \%$ of the EGF-R remained in wild type hepatocytes, whereas Vtilb deficient cells from normal size mice had 34,4 \pm 7,6 \% undegraded EGF-R ( $n=4$, two 
independent experiments). The difference in EGF-R degradation between control hepatocytes and hepatocytes from small knock-out mice was greater. Control cells had $28,2 \pm 8,9 \%$ of the EGF-R left over after $4 \mathrm{~h}$ and hepatocytes from small knock-out mice kept 51,2 $\pm 2,0 \%(\mathrm{n}=2$, one experiment) (fig 24$)$. So there was a retardation of EGF-R delivery to or degradation in lysosomes.

\subsubsection{Uptake and degradation of ${ }^{125} \mathrm{I}$-asialofetuin in Vti1b deficient hepatocytes}

The cell biology of the asialoglycoprotein receptor (ASGP-R) system provides insights into the fundamental process of receptor-mediated endocytosis. The asialoglycoprotein receptor is found exclusively in hepatic parenchymal cell membranes. It recognises carbohydrate moieties with a terminal galactose in ligand molecules. The ASGP-R mediates the specific recognition and receptor-mediated hepatic uptake of glycoproteins with a terminal galactose (Breitfeld et al. 1985). After internalisation with its bound ligand, this empty receptor is recycled back to the cell surface, whereas the ligand is transported to lysosomes for degradation. Products of degradation can be detected in the medium.

${ }^{125} \mathrm{I}$-asialofetuin was used as ligand of ASGP-R to monitor receptor-mediated endocytosis in wild type and Vtilb deficient hepatocytes. Cells were starved in serum-free RPMI medium supplemented by $0,1 \%$ BSA for $4 \mathrm{~h}$. Starvation medium was replaced with starvation medium containing 10pmol/ml (126600 cpm/plate) of ${ }^{125}$ I-asialofetuin (1:100 dilution of labelled solution, $6 \mu \mathrm{l}$ in $600 \mu \mathrm{l}$ of medium for each plate for $4 \mathrm{~h}$ and iodinated asialofetuin was added and incubated with the cells for $20 \mathrm{~min}$ at $37^{\circ} \mathrm{C}$ (pulse). Afterwards, the radioactive medium was removed, cells were washed with medium and incubated with new portions of fresh medium for 30min, $60 \mathrm{~min}$ and 120min (chase). Medium and cells were collected, soluble (amino acids) and insoluble (protein bound) radioactivity was separated after TCA precipitation. Degradation rates were calculated as $\%$ of TCA soluble radioactivity in comparison to the sum of soluble radioactivity and cell associated insoluble radioactivity for each time point. About $8000-16000 \mathrm{cpm}$ were taken up by the cells depending on cell density.

Wild type hepatocytes and hepatocytes of normal size Vtilb knockout mice degraded asialofetuin at similar rates(fig 25). An average of 46,5 $\pm 4,1 \%$ of the asialofetuin was degraded in wild type hepatocytes after $30 \mathrm{~min}$ of chase (three independent experiments with double values). Vtilb deficient hepatocytes from normal size mice degraded 47,6 \pm 
$3,6 \%$ asialofetuin in same time (double values of one experiment). Other chase periods also showed insignificant differences between these cells (see fig 25)

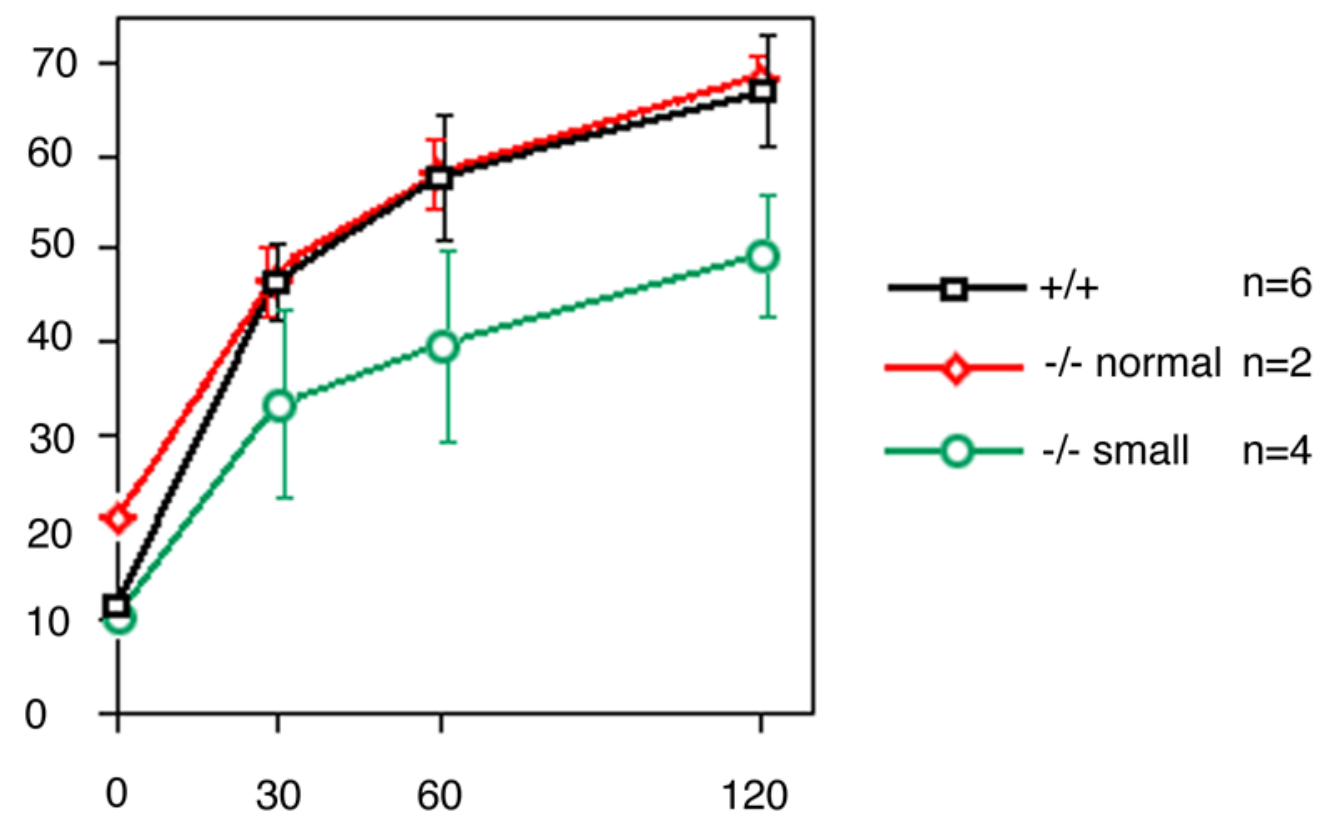

Figure 25: J125-asialofetuin degradation after 20 min pulse, different chase periods

$\mathrm{X}$ axis indicates time in min, $\mathrm{Y}$ axis - \% of degradation of asialofetuin (soluble radioactivity in the assay); -/-small are mice N33 and N101

However, hepatocytes from small Vtilb deficient mice had slower rates of asialofetuin degradation. After $30 \mathrm{~min}$ they had only $33,1 \pm 8,8 \%$ soluble radioactivity (two independent experiments with double values). The same tendency could be observed after 60min and 120min. After 60min deficient hepatocytes from small mice had 39,6 $\pm 9,0 \%$ asialofetuin which was much less then 58,1 $\pm 6,9 \%$ for wild type cells. After two hours chase control hepatocytes had $66,7 \pm 6,3 \%$ soluble radiactivity which was significantly higher then 49,4 \pm 4,3\% for hepatocytes from small Vtilb knockout mice.

Asialofetuin degradation in hepatocytes from small Vtilb deficient mice was retarded. By contrast, no defect in asialofetuin degradation was observed in hepatocytes derived from normal size Vtilb deficient mice.

\subsubsection{Transport of newly synthesised cathepsin D in MEFs and cultivated hepatocytes}

Usually the lysosomal protease cathepsin D is transported from the TGN to endosomes and then lysosomes via a manose-6-phosphate receptor dependent pathway. Some fraction of 
the precursor, procathepsin D, fails to be captured by the MPR-46 receptor. This procathepsin D is secreted and then endocytosed with the help of MPR-300. Procathepsin $\mathrm{D}(55 \mathrm{kDa})$ is processed in lysosomes to an intermediate form of about $45 \mathrm{kDa}$ which is then cleaved into two mature forms of $30 \mathrm{kDa}$ and $14 \mathrm{kDa}$.

To trace procathepsin D processing wild type and Vtilb deficient MEFs were incubated for $1 \mathrm{~h}$ with $\left[{ }^{35} \mathrm{~S}\right]$-methionine (pulse). An excess of non-radioactive L-methionine was was then added and cells were incubated for $1 \mathrm{~h}, 2 \mathrm{~h}$ and $4 \mathrm{~h}$ (chase). For hepatocytes chase periods of $2 \mathrm{~h}$ and $4 \mathrm{~h}$ were applied. Afterwards cathepsin D was immunoprecipitated from medium and cell homogenates, separated by SDS-PAGE and analysed using a phosphoimager.

\section{Experiments using MEFs}

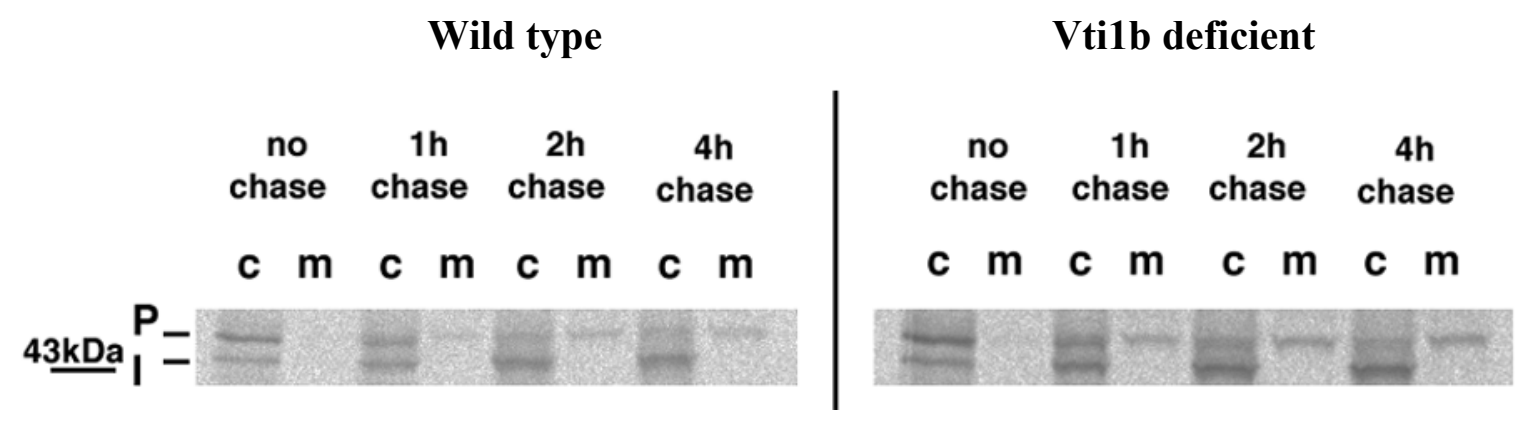

Figure 26: Processing of cathepsin D in control and Vti1b deficient MEFs

P- precursor; I - intermediate form; "c"- precursor and intermediate form in cell homogenates, "m"- cathepsin D secreted into the medium

Figure 26 shows processing of cathepsin D precursor to intermediate form in MEFs. The sum of procathepsin D, intermediate form and secreted cathepsin D is set to $100 \%$ for each time point.

Control fibroblasts secrete $10 \%$ of the new synthesised precursor into the medium after $4 \mathrm{~h}$. Vtilb deficient MEFs secreted slightly more (15\%).

In general strong differences between control and Vtilb deficient fibroblasts in cathepsin D maturation were not observed (three independent experiments). Table 8 shows quantified results of a single experiment. 
Table 8: Quantitative analysis of cathepsin D processing in MEFs

\begin{tabular}{|l|cc|cc|cc|}
\hline & \multicolumn{2}{|c|}{ Precursor } & \multicolumn{2}{|c|}{$\begin{array}{c}\text { Intermediate } \\
\text { form }\end{array}$} & \multicolumn{2}{|c|}{$\begin{array}{c}\text { Secreted into } \\
\text { medium }\end{array}$} \\
\hline & $+/+$ & $-/-$ & $+/+$ & $-/-$ & $+/+$ & $-/-$ \\
\hline no chase & 72 & 71 & 28 & 29 & --- & -- \\
\hline 1h chase & 47 & 36 & 47 & 51 & 6 & 13 \\
\hline 2h chase & 23 & 23 & 67 & 63 & 10 & 14 \\
\hline 4h chase & 20 & 15 & 70 & 70 & 10 & 15 \\
\hline
\end{tabular}

Values show \% of cathepsin D from total amount

\section{Experiments using isolated hepatocytes}

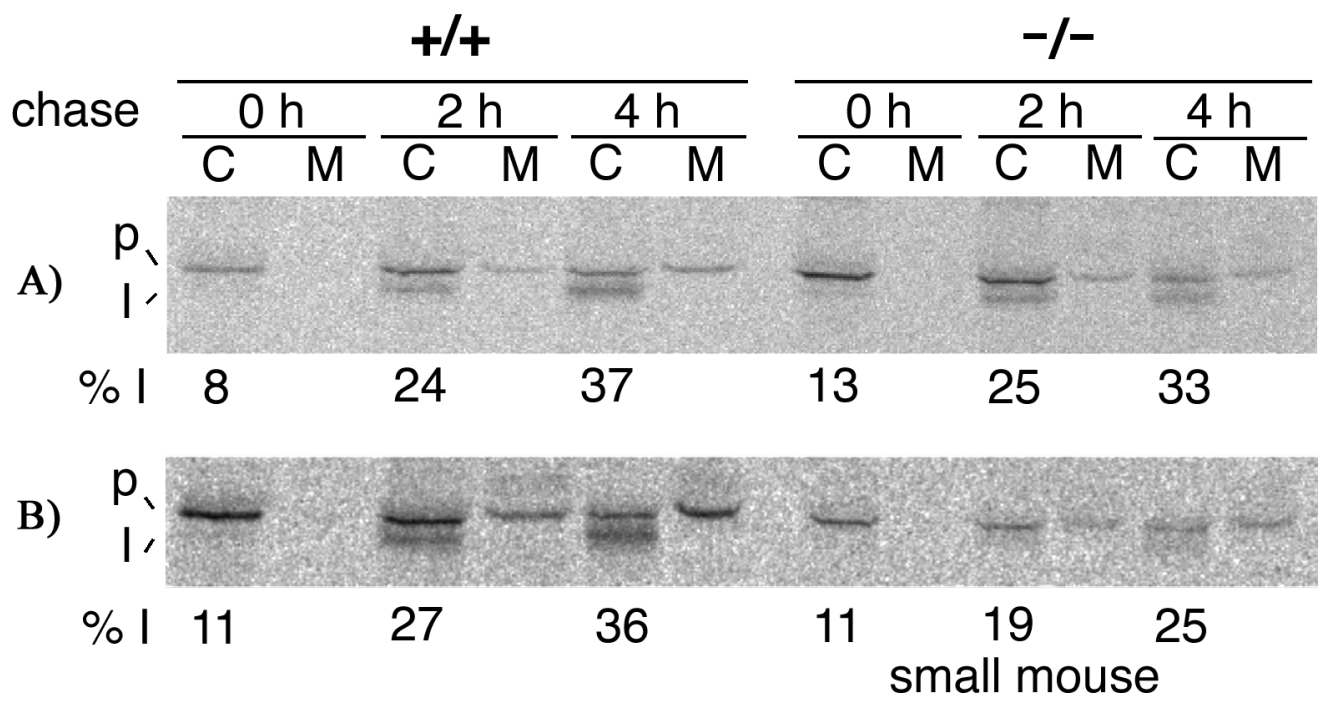

Figure 27: Visible delay of Cathepsin D maturation in hepatocytes of small Vti1b deficient mice

Panel A: Similarity of cathepsin D processing in hepatocytes of control and of normal size Vtilb knock-out mice; Panel B: Difference in the amounts of cathepsin D intermediate form between wild type hepatocytes and hepatocytes of small size Vtilb knock-out mouse N101. Numbers under the panel indicate percents of intermediate form

Figure 27 shows the processing of new synthesised cathepsin D in wild type and Vtilb deficient hepatocytes. Wild type hepatocytes and hepatocytes of normal size Vtilb knockout mice showed similar cathepsin D maturation (panel A).Control hepatocytes had 23,8 \pm $5,0 \%$ intermediate form after $2 \mathrm{~h}$ and $36,6 \pm 6,8 \%(\mathrm{n}=6)$ after $4 \mathrm{~h}$ of chase. This was not 
significantly different in hepatocytes of normal size Vti1b deficent mice $(24,6 \pm 3,4 \%$ intermediate form after $2 \mathrm{~h}, 33,3 \pm 5,7 \%$ after $4 \mathrm{~h}$ ) Hepatocytes of small deficient mice (panel B) had slightly less intermediate form after $2 \mathrm{~h}(18,5 \pm 2,5 \%)$ and $4 \mathrm{~h}(25 \pm 2 \%)$ (fig 28). This experiment was not repeated due to the limited number of small Vtilb deficient mice but fits with the defects in endocytosis and lysosomal degradation seen in these mice (4.1.11 and 4.1.12).

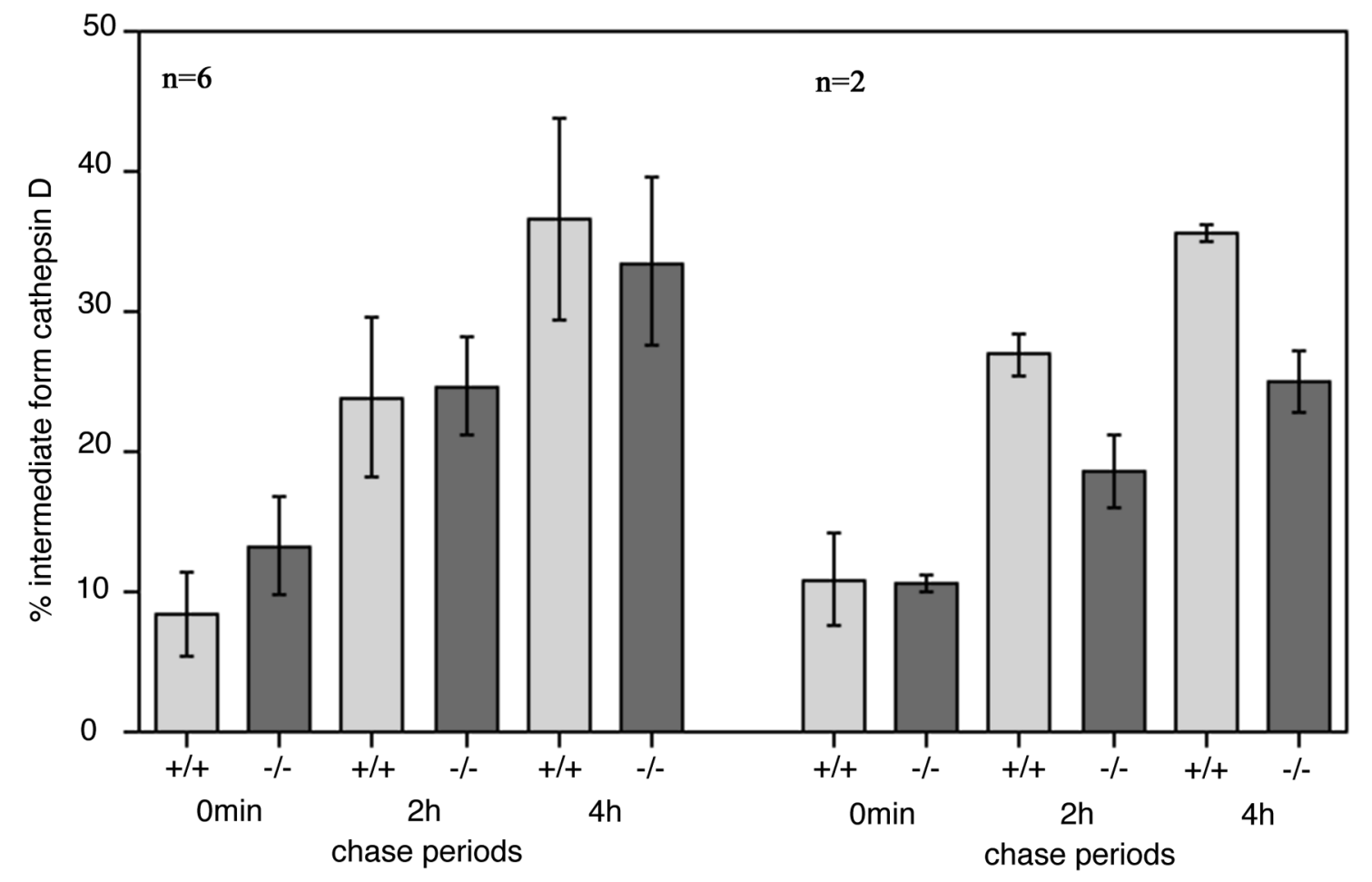

Figure 28: Quantitative comparison of the cathepsin D processing in hepatocytes of wild type, normal size (left panel) and small (right panel) Vtilb deficient mice

The left panel of figure 28 shows similar maturation pattern of cathepsin D in control and normal size Vtilb knock-out mice ( $\mathrm{n}=6$, three independent experiments with double values). The right panel demonstrates a slight retardation of cathepsin $\mathrm{D}$ processing in small knock-out mice ( $\mathrm{n}=2$, one experiment with double values).

\subsubsection{Rates of autophagocytosis in hepatocytes of normal size deficient mice}

Degradation of long-lived proteins occurs mainly by autophagy (Henell et al. 1987). Cells lacking LAMP-2 accumulate autophagic vacuoles (Tanaka et al. 2000). To find out if autophagy is affected in Vtilb deficient cells, an assay applied by Tanaka et al.was used. 
Autophagosomes fuse with lysosomes during their maturation resulting in the subsequent degradation of the enclosed material. Amino acid deprivation is a potent inducer of autophagy. For labelling of all newly synthesised proteins hepatocytes were incubated with $\left[{ }^{14} \mathrm{C}\right]$-valine for 24 hours then washed with medium twice and exposed to salt solution or fresh medium for $1 \mathrm{~h}$. During that time short-lived proteins were degraded. Medium was changed and one group of hepatocytes was incubated for $3 \mathrm{~h}$ with basic salts solution (no amino acids) to stimulate autophagocytosis strongly. Other groups of hepatocytes were incubated with normal medium supplemented by $5 \%$ serum for $11 \mathrm{~h}$ and $23 \mathrm{~h}$ to observe background levels of autophagocytosis. Medium and cell homogenates were collected. After TCA precipitation insoluble radioactive material (proteins) was separated from soluble (amino acids). Rates of autopagocytosis were calculated as \% soluble radioactivity of the total radioactivity in cell homogenates and medium.

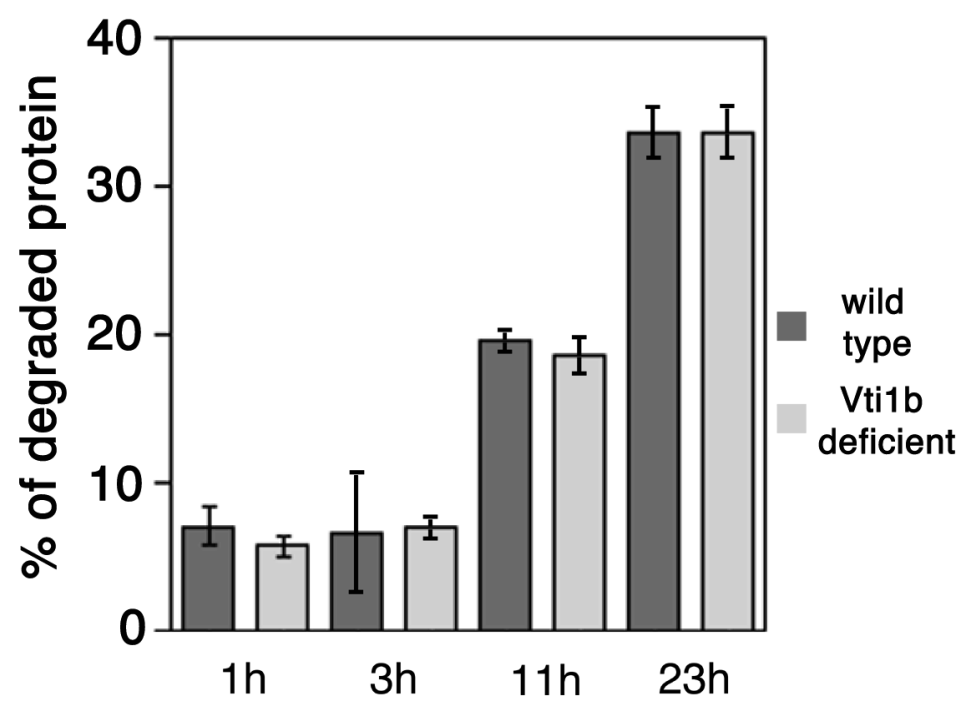

Figure 29: Induced and basic autophagy in control and Vtilb-/- hepatocytes

$\mathrm{n}=4$, two independent experiments with double values

Wild type hepatocytes and hepatocytes of normal size knock-out mice showed similar behaviour in this assay (fig 29). The average values of protein degradation after stimulation for $3 \mathrm{~h}$ without amino acids were $6,6 \pm 3,4 \%$ in wild type and 6,9 $\pm 0,9 \%$ in Vtilb knock-out hepatocytes. The basic autophagic degradation of long-lived proteins after $11 \mathrm{~h}$ was $19,5 \pm 0,6$ and $18,6 \pm 1,6 \%$ in wild type and Vtilb deficient hepatocytes, respectively. After $23 \mathrm{~h}$ identical values were obtained in control and deficient cells $(33,5 \pm$ $1,8 \%$ and $33,5 \pm 1,8 \%)$. 
This information correlates with data of electron microscopy, where autophagic vacuoles are morphologically very similar in control hepatocytes and cells of normal size knock-out mice (fig 30, under 4.2.13).

\subsubsection{Electron-microscopic study of Vti1b deficient hepatocytes}

Cultivated hepatocytes of wild type and Vtilb deficient mice were studied by electron microscopy by Eeva Liisa Eskelinen, University of Dundee, UK. This gives information about morphology of endosomal and lysosomal structures and autophagic vacuoles. Isolated hepatocytes were fixed in $2 \%$ glutaraldehyde in $0,2 \mathrm{M}$ Hepes, $\mathrm{pH} 7,4$. The cells were scraped off the culture dish and postfixed in $1 \% \mathrm{OsO}_{4}$ for $1 \mathrm{~h}$, dehydrated in ethanol and embedded in Epon. Micrographs were taken with a primary magnification of x10,000. Vacuoles were classified as early (AVi), containing morphologically intact cytoplasm or late(AVd), containing partially degraded but identifiable cytoplasmic material.

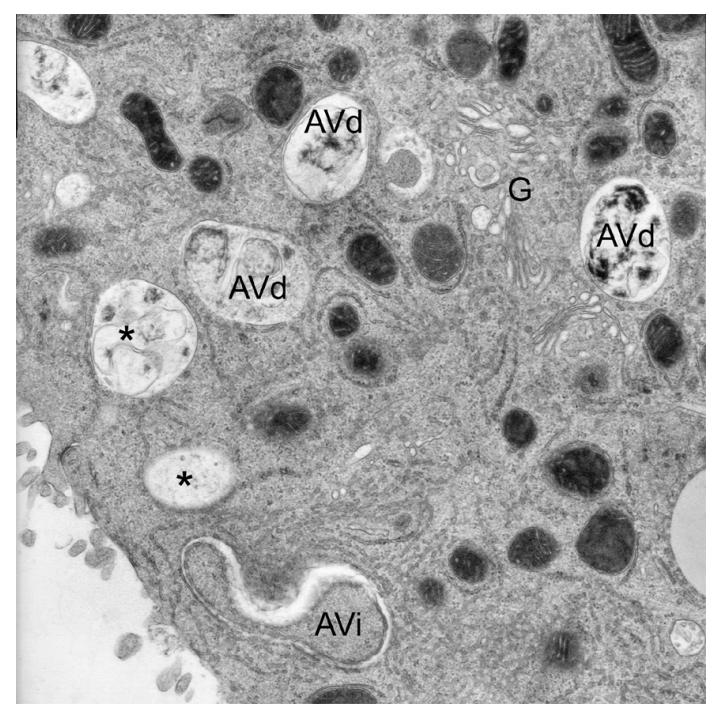

A)

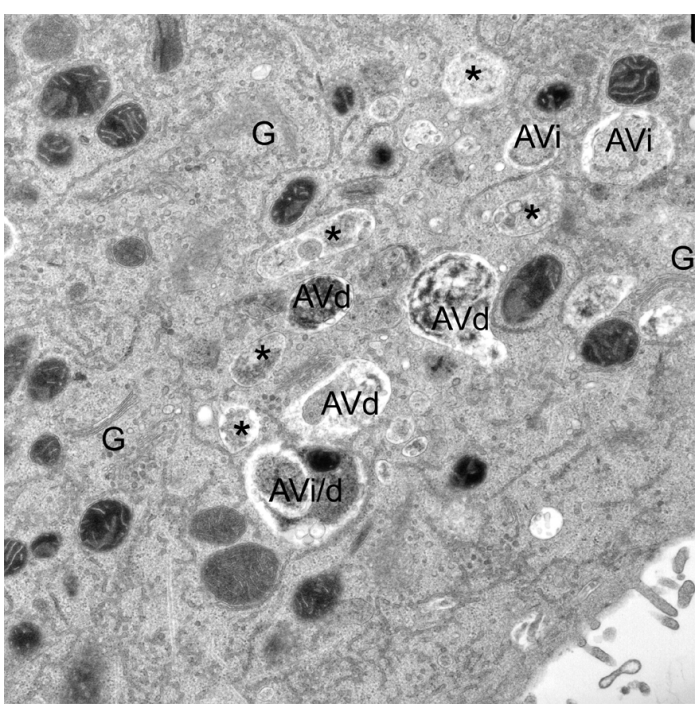

B)

Figure 30: Morphology of endosomes, lysosomes and autophagic vacuoles in wild type hepatocytes and hepatocytes from Vtilb deficient mice of normal size

(provided by Eeva Liisa Eskelinen) AVi - early, AVd - late autophagic vacuoles; G indicates Golgi stack, stars present endosomes and lysosomes; Panel A) represents wild type, panel B) - Vti1b deficient hepatocytes

There were no obvious morphological differences between wild type hepatocytes and hepatocytes from Vtilb deficient mice of normal size. Both showed some autophagic vacuoles in the cytoplasm, both early $(\mathrm{AVi})$ and late $(\mathrm{AVd})$. There was no accumulation of AVi or AVd in the deficient cells, as compared to controls. Endosomes and lysosomes had 
similar morphology in Vtilb deficient hepatocytes from mice of normal size and wild type hepatocytes (fig 30).

Hepatocytes of small deficient mice showed a very different pattern. They accumulated both early and late autophagic vacuoles. Interestingly, a close contact between different autophagic vacuoles and/or between multivesicular bodies was often observed. In addition, several of these vacuoles had lost their limiting membranes in the contact zone but had still retained their morphology, indicating they were in the process of fusion (fusion profiles). There were a lot of small multivesicular bodies in hepatocytes of small size knock-out mice. Some multivesicular bodies were inside of autophagic vacuoles(fig 31).

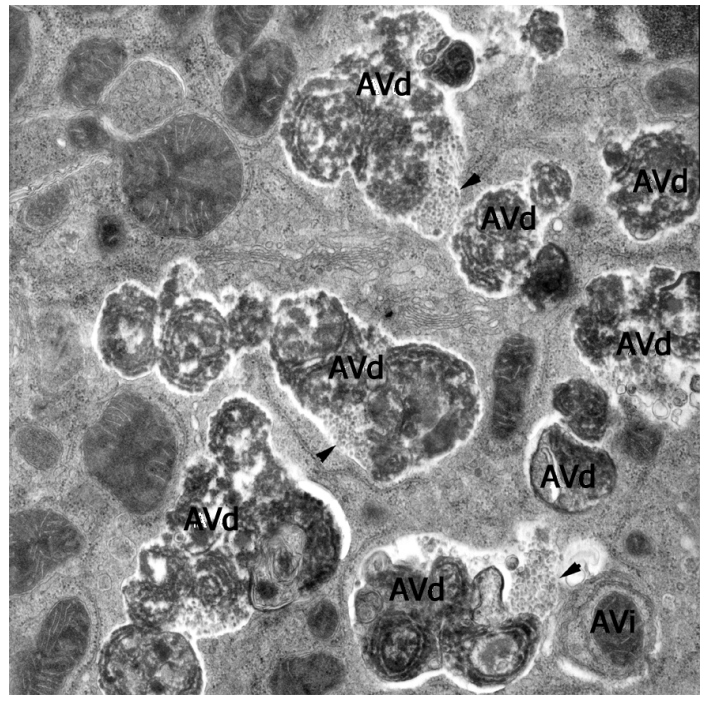

A)

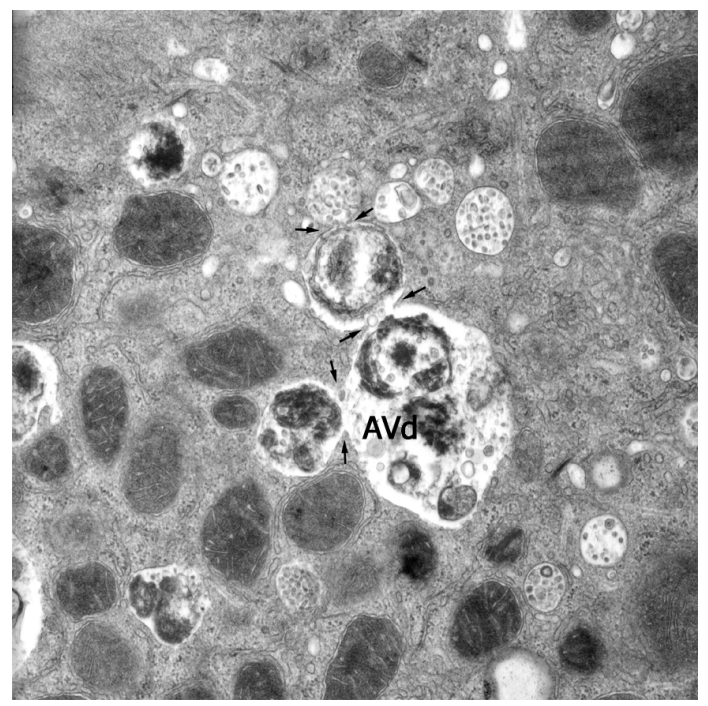

B)

\section{Figure 31: Morphology of endosomes, lysosomes and autophagic vacuoles in} hepatocytes from Vti1b deficient mouse of small size N101

(provided by Eeva Liisa Eskelinen) AVi - early, AVd - late autophagic vacuoles Panel A) shows accumulation of late autophagic vacuoles, arrows indicate multivesicular areas; panel B) shows a close contact between different autophagic vacuoles (fusion profiles), arrows indicate contact zones 


\subsection{Isolation of genomic DNA for Vti1a, characterisation of the chromosomal region of $\mathrm{Vti1} a$ and construction of targeting vectors}

Two EST (express sequence tag) clones containing Vtila coding sequence were used as DNA probes to screen a $\lambda$-phage mouse strain Sv129 Ola genomic DNA library for Vtila genomic fragments. One of them, probe "237", contained the complete coding sequence for Vtila plus $100 \mathrm{bp}$ upstream of the ATG codon and 60bp downstream of the stop codon as cDNA.

brain-specific exon inserted between Phages C1 and C2
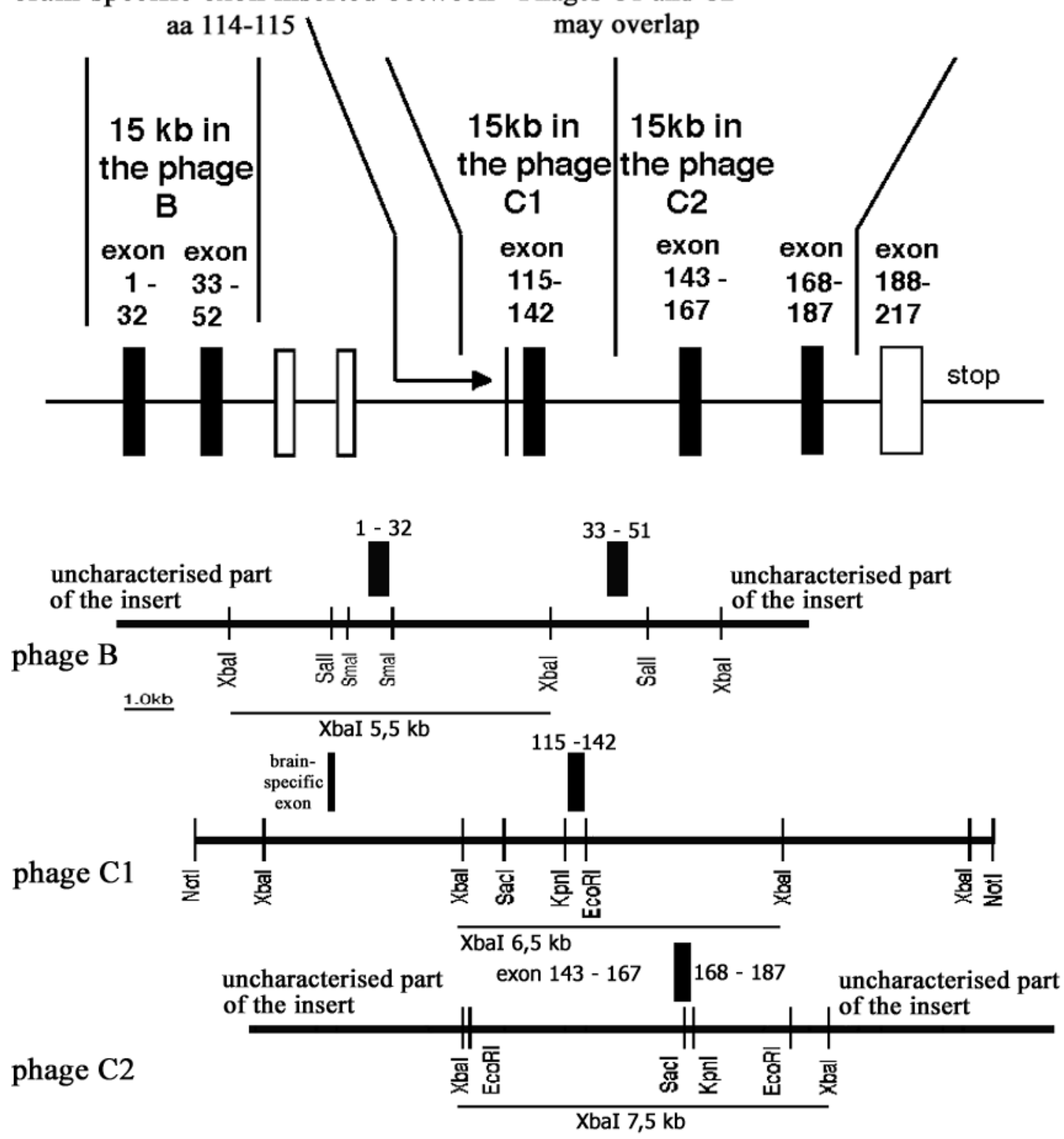

Figure 32: Fragments obtained of the Vti1a genomic region 
The probe was obtained from the EST clone AA016379 which contains these sequences inside of the pT7T3D plasmid by XhoI/NotI digestion. The second one, "EST probe", contained 100bp 5 untranslated region, the first exon and $750 \mathrm{bp}$ intron sequence of Vtila. This probe was obtained after digestion of the plasmid pT7T3D (AA097517) with XhoI/NotI. Three phage clones were detected ("phage B”, "phage C1", "phage C2”). Probe "EST" allowed to detect phage "B", probe "237" detected phages "C1" and "C2".

The chromosomal region for Vtila was at least three times larger than the one for Vtilb. Not all exons were present in the three phages isolated (fig 32). Important for working out the knock-out strategy was to obtain the exon encoding amino acids 115-142 which was contained inside of "phage C1". This exon encodes part of the SNARE motif which is responsible for complex formation and is therefore critical for Vtila function. Desruption of exon 115-142 would prevent synthesis of functional Vtila protein even in the unlikely case that its mRNA should be stable.

Phage B contained exons "1-32" and "33-52" (figure 32), phage C1 contained a small exon encoding 7 amino acids of the brain specific insertion and exon "115-142", phage C2 contained exons "143-167" and "168-187".

\section{A) Strategy for constitutive knock-out}

A chromosomal DNA insert of $6,5 \mathrm{~kb}$ length was cut out from "phage $\mathrm{Cl}$ " by $\mathrm{XbaI}$ and subcloned into pBluescript $\mathrm{SK}+$ plasmid for characterisation $\left(\mathrm{pVA}_{28}\right)$. A $6 \mathrm{~kb}$ fragment of that DNA subcloned using XbaI/AvrII endonucleases and used for targeting vector construction. Since the exon of interest (“exon 115-142") contains a KpnI site it was possible to subclone the $\mathrm{Neo}+$ desruption cassette into this KpnI site with the coding sequence on the opposite strand as Vtila without other DNA - manipulations (fig 33). 
A)

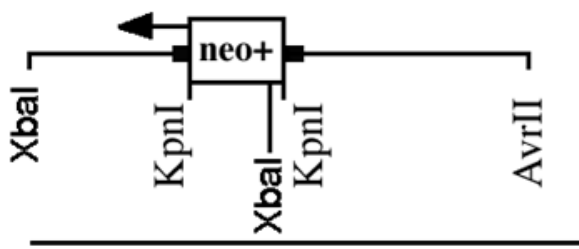

Xbal $6.5 \mathrm{~kb}$

NdeI $4 \mathrm{~kb}$

exon

$1.0 \mathrm{~kb}$

115-142

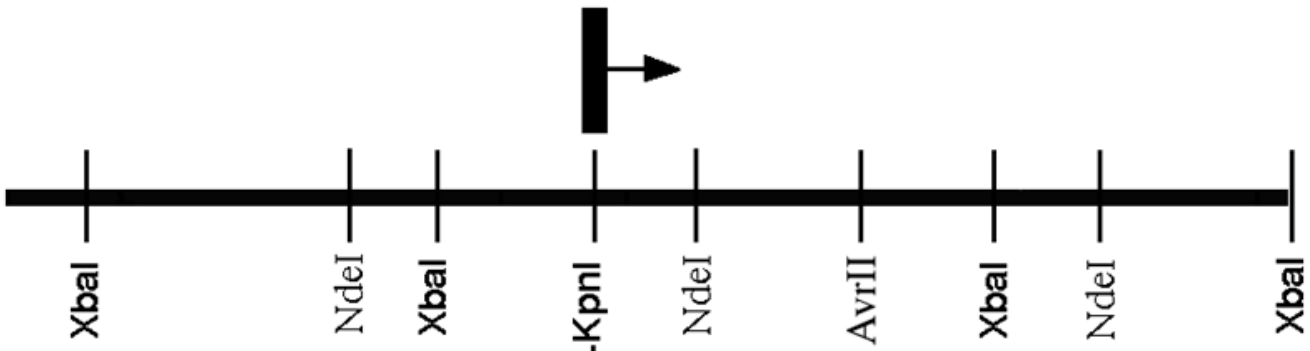

B)

C)

pVA45 derived probe

pVA42 derived probe

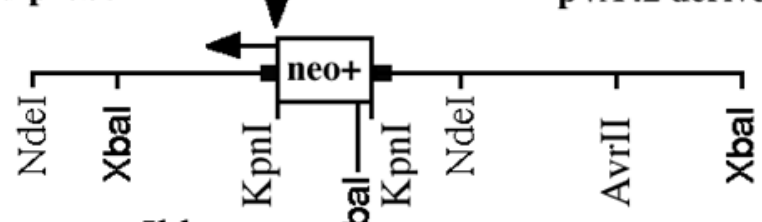

D) pVA45 derived probe

$5 \mathrm{~kb}$

$\stackrel{2}{x}$

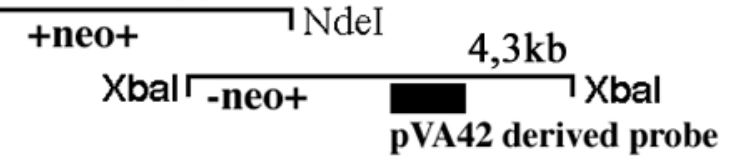

\section{Figure 33: Scheme of the Vti1a targeting construct and screening strategy}

A) the insert of the Vtila targeting vector; B) scheme of Vtila chromosomal region;

C) Vtila chromosomal region after homologous recombination; D) size of fragments to be recognised by the chosen probes

Two DNA probes were designed for screening for positive ES cell transformants. "pVA $\mathrm{A}_{42}$ derived" probe was obtained after SpeI/AvrII shrinking of $\mathrm{pVA}_{28}$ bearing an insert of 1,4 $\mathrm{kb}\left(\mathrm{pVA}_{42}\right)$. This probe was $700 \mathrm{bp}$-long and was cut out by $\mathrm{XbaI} / \mathrm{EcoRV}$ enzymes.

"pVA 45 derived" probe was obtained after EcoRI shrinking of the phage DNA insert of $\mathrm{pVA}_{41}$ which contained 4,3kb upstream of the XbaI fragment with exon "115-142". This probe was 490 bp-long was cut out by XbaI/EcoRI enzymes.

Upon screening for positive ES clones using DNA hybridisation techniques, the 5' outside probe derived from $\mathrm{pVA}_{45}$ would recognise a $5 \mathrm{~kb}$ NdeI fragment with the Neo-insertion after homologous recombination together with a $4 \mathrm{~kb}$ wild type one. The 3 'outside probe 
derived from $\mathrm{pVA}_{42}$ would recognise a 4,3kb XbaI fragment with the Neo-insertion after homologous recombination and a $6,5 \mathrm{~kb}$ wild type one.

The targeting vector was introduced into embryonic stem cells of MPI ES cell line. A homologous recombination was observed in only one clone among 130 clones tested. Figure 34 shows that clone number 8 had an insertion of the Neo-cassette into the Vtila locus. It was used for microinjection of blastocysts.

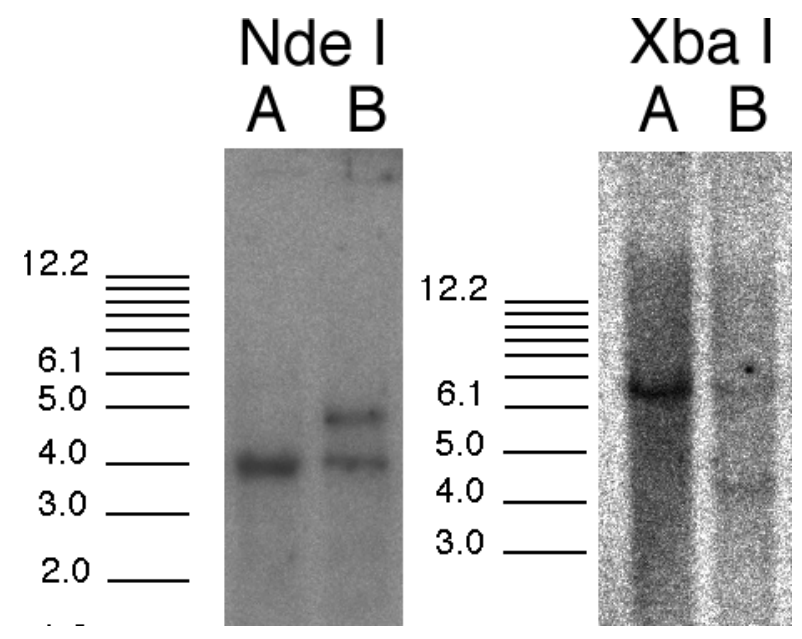

Figure 34: MPI ES clone 8 is positive Vti1a targeted $\mathrm{A}$ - wild type, $\mathrm{B}$ - mutant clone 8

Chimeric mice were obtained. Six male mice with low chimerism (5-20\%) and one mouse with $60 \%$ chimerism were used for mating but no germ line transmission was obtained. Recently a new positive clone was obtained (clone 132) which belongs to another ES cell type E-14. Transfer of the clone 132 into blastocysts was done recently.

\section{B) Strategy of conditional knock-out}

It is unknown if Vtila deficiency is lethal. In case of early embryonic lethality it would be impossible to get any embryonic fibroblasts and study the functional role of Vti1a. Another knock-out strategy was worked out, namely a conditional knock-out (fig 35) 
A)

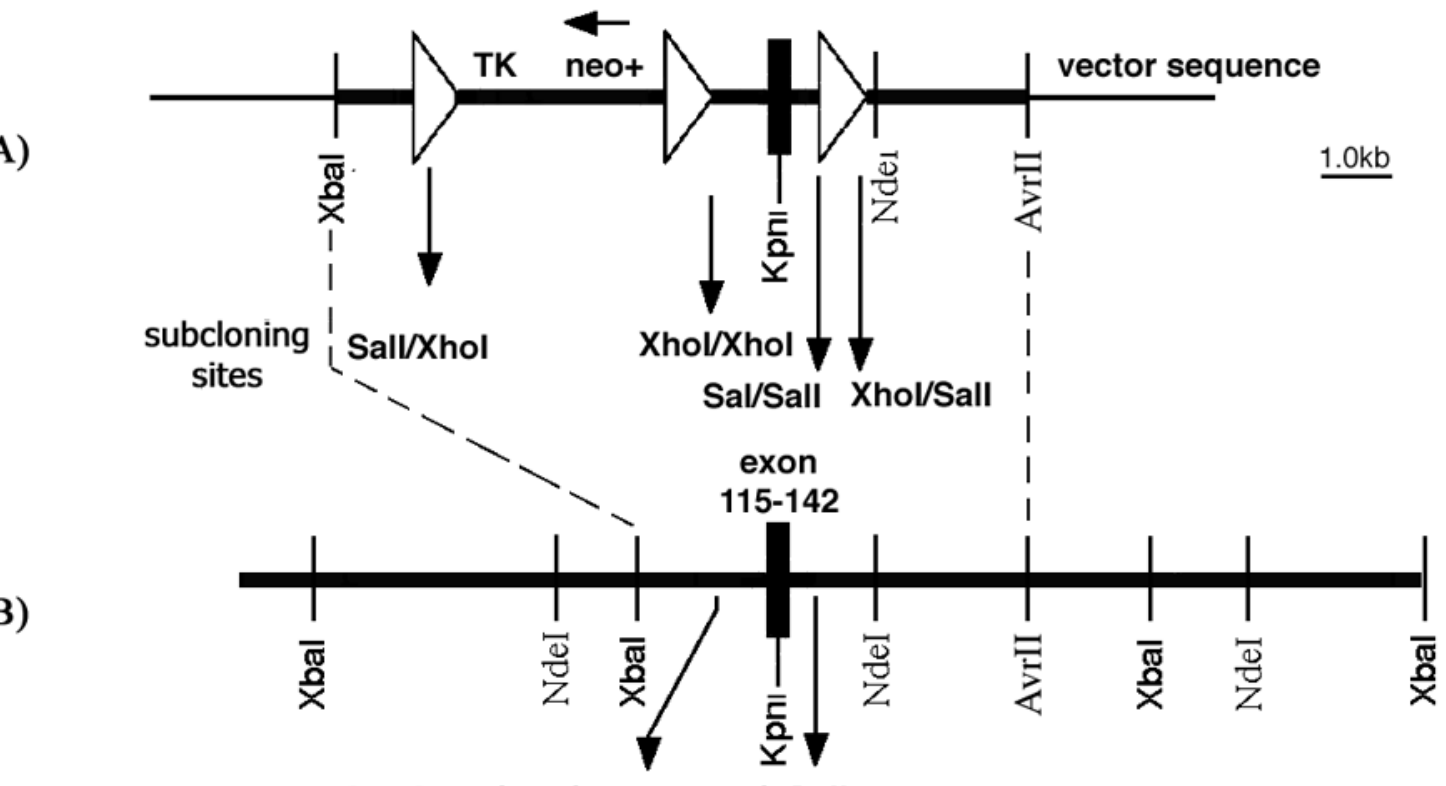

sites introduced: Xhol and Sall

B)

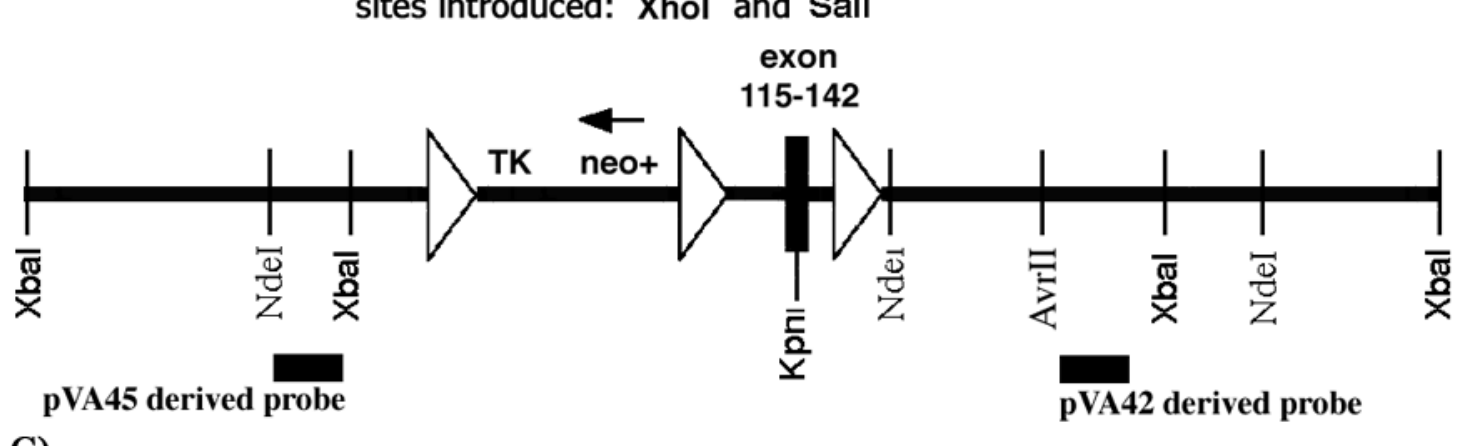

C)

Figure 35: Scheme of the targeting strategy and the construct for Vtila conditional knock-out
A) Targeting construct; B) chromosomal region after homological recombination
C) Mutant Vtila

The same genomic fragment containing "exon 115-142" that was shorted by XbaI/AvrII endonucleases was used to make a new construct. LoxP sites for recognition of DNA by Cre-recombinase were introduced before and behind the exon of interest. Using oligonucleotide-directed mutagenesis SalI and XhoI sites were introduced into the $6,5 \mathrm{~kb}$ $\mathrm{XbaI}$ chromosomal Vtila region contained in $\mathrm{pVA}_{54}$. For introducing a SalI site $120 \mathrm{bp}$ downstream of the exon into $\mathrm{pVA}_{54}$ following primers were used CGACAATTGGGAGCTTATTTGC and ACCCAATATGTAAACCACATC. The resulting plasmid $\mathrm{pVA}_{56}$ was used as template to introduce a XhoI site $134 \mathrm{bp}$ upstream of the exon. The following PCR primer pair was used for that:

GAGAACTGTCTGCTAAAATTTAAC and GAGAGGAAACACAACAATAGAC. 
Thymidin-kinase and Neo+ cassettes flanked by two LoxP sites (altogether $3 \mathrm{~kb}-\mathrm{long}$ ) were subcloned into the XhoI site of the plasmid $\mathrm{pVA}_{57}$ obtained after two mutagenesis. One additional 140 bp-long DNA fragment containing a LoxP site of same orientation was subcloned into the SalI site, giving raise to $\mathrm{pVA}_{59}$ (targeting construct). Upon screening for positive ES clones using DNA hybridisation techniques, one of the chosen probes would recognise a mutant $7,2 \mathrm{~kb}$ NdeI fragment together with a $4 \mathrm{~kb}$ original one. The other probe would recognise a 9,5kb mutant $\mathrm{XbaI}$ fragment and a 6,5 $\mathrm{kb}$ native one.

Positive clones will be expanded and Cre-recombinase will be added to induce excision of the TK-Neo+ containing DNA fragment. In this case the same probes will be used for the screening strategy. Upon screening for positive ES clones using DNA hybridisation techniques, one of the chosen probes ("pVA 45 derived") would recognise the exon flanked by two LoxP sites as $4.4 \mathrm{~kb}$ NdeI fragment and a 3,9kb fragment if the exon has been excised. Another probe ("pVA 42 derived") would recognise a 4,5kb fragment after $\mathrm{XbaI}+\mathrm{KpnI}$ digest if the exon is flanked by two LoxP-sites and a $6,5 \mathrm{~kb}$ fragment if the exon has been removed. 


\section{Discussion}

\subsection{Generation of deficient mice to characterise the role of Vtilb in endosomal traffic}

The present work demonstrates that Vtilb is a non-essential protein in mice. Lack of Vtilb does not causes abnormalities in most mice, but a few mice are smaller in size. Vtilb is needed in vivo for proper endosomal traffic in hepatocytes of small Vtilb deficient mice, but its absence can be compensated for Vtilb deficient mice of normal size. The absence of Vtilb leads to reduced levels of syntaxin 8.

\subsubsection{Homology of mouse Vti1 proteins}

Vtilb and Vtila are SNAREs. They possess each a SNARE motif and a transmembrane domain. The overall homology between them is only $30 \%$ amino acid identity. Vtilb and Vtila are Qb-SNAREs, however Vtila has an aspartate in the 0 layer. Aspartate like glutamine has a carbonyl group as side chain and is similar in size to glutamine. Because arginine interacts with the carbonyl group of glutamine in the 0 layer, an aspartate residue should therefore be able to interact with the arginine of the R-SNAREs. The amino acid identity of Vtilb and Vtila in the SNARE motif is $42 \%$ and that makes it possible that they have different functions in membrane traffic.

Vtilb and Vtila genes are located on different chromosomes. Human Vtilb is located on chromosome 14q23 at 65,5 Mb. Accordingly to chromosomal homologies between mouse and human it can be proposed that mouse Vtilb is encoded on chromosome 12 at 39-40 cM. In both organisms the $3{ }^{`}$ untranslated ends of Vtilb and Arginase II cDNAs overlap. Vtila is encoded on human chromosome 10q25 and probably on mouse chromosome 19 at $50 \mathrm{cM}$. In this work it is shown that the chromosomal region encoding Vti1a is at least three times larger than the chromosomal region of Vtilb.

An alignment of sequences with exon/intron boundaries of mammalian Vti1 proteins is shown in fig 36 


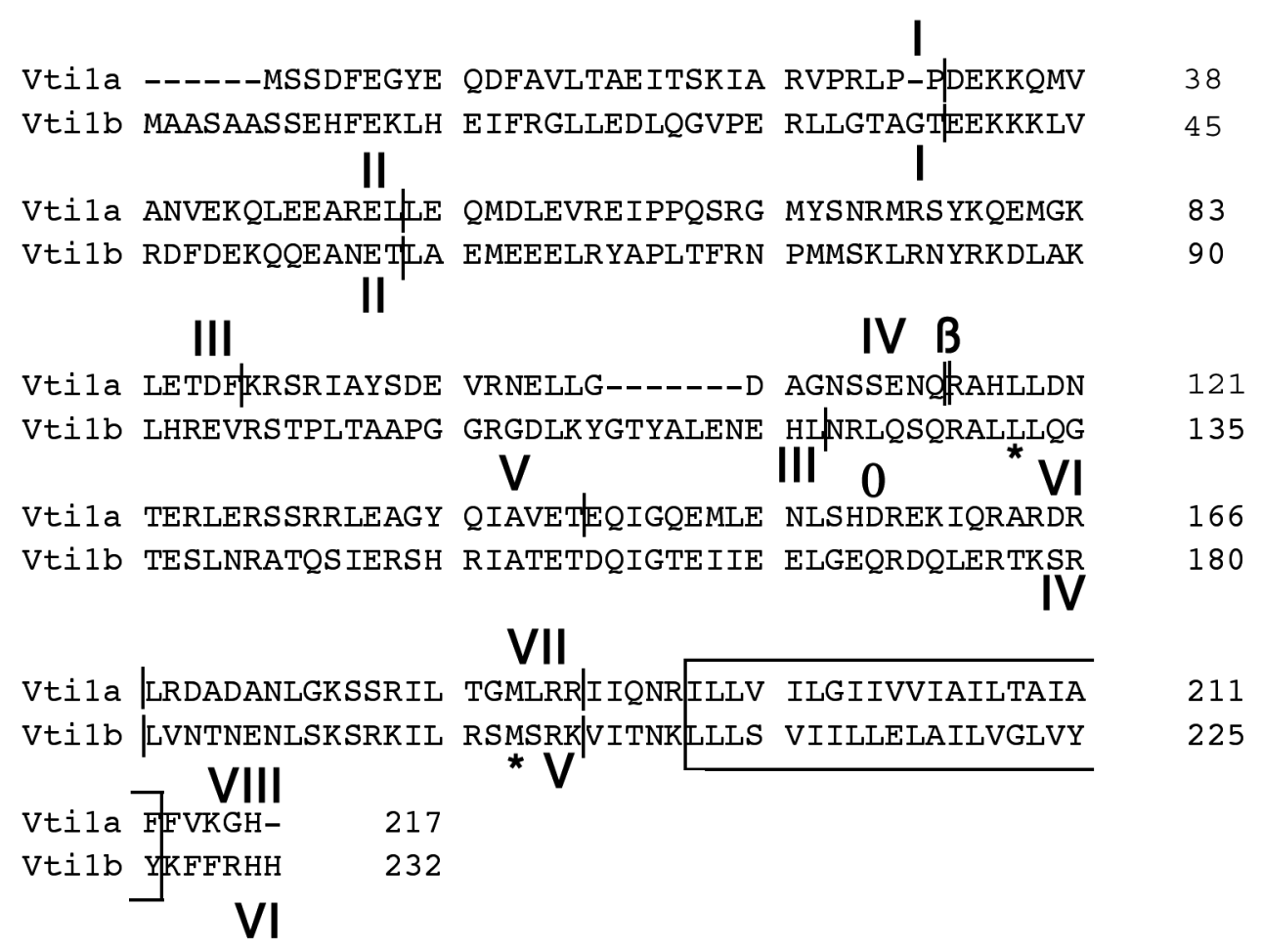

Figure 36: Exon/intron structure in mouse Vtila and Vti1b proteins lexon/intron boundaries; I-VIII numbers of exons; * boundaries of the SNARE motif; $\boldsymbol{B}$ place of additional exon in Vtila- $\beta ; \mathbf{0}-0$ layer

The mouse chromosomal DNA sequences characterised in this work did not include the complete genes. In case of Vtilb the first two exones were absent in the obtained DNA fragment. Hence, the first exon/intron boundary for Vtilb were taken from human theVtilb sequence in the Genbank database. Of course the real position of this boundary in mouse Vtilb gene may still be different. The characterised fragments of Vtila chromosomal DNA contained exones I, II, but not III and IV, therefore the boundary between exones III and IV is derived from the human sequence in fig36. An additional exon of Vtila that encodes the brain-specific insertion of 7 amino acid residues giving rise to the splice form of Vtila, termed Vtila- $\beta$, is located at a distance of $4,2 \mathrm{~kb}$ upstream of exon $\mathrm{V}$.

Vtilb consists of 6 exons, Vtila of 8 exons plus the alternatively spliced brain specific exon. It is striking that 4 of the intron-exon boundaries in Vtilb are found in homologous positions in Vtila, boundaries of exones I and II match for Vtilb and Vtila genes. This may suggest that the intron-exon structure developed before the gene duplicated and evolved into 2 different genes. 


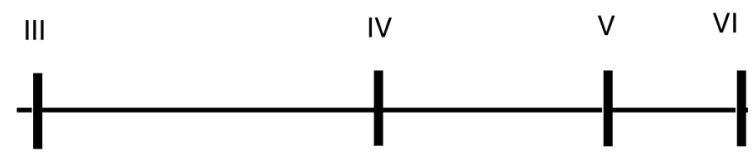

a) mVti1b

$1 \mathrm{~kb}$

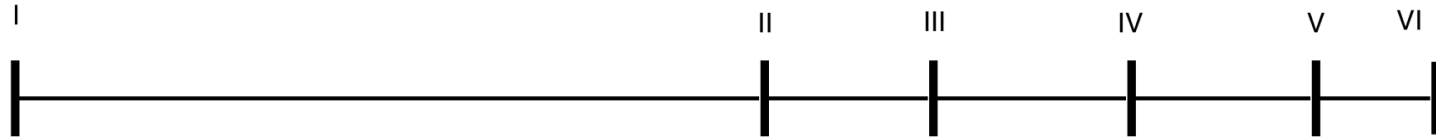

b) hVti1b

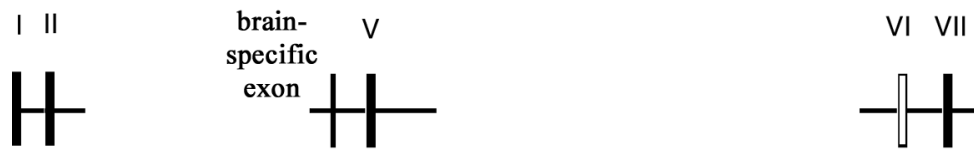

c) mVti1a

I II III VIV V $\quad$ VI VII

$\underline{10 \mathrm{~kb}}$

-1|

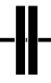

VIII

d) hVti1a

Figure 37: Comparison of mouse and human Vti loci

- determined position of an exon; - undetermined position of an exon

The Vtila chromosomal DNA with exons I, II, V, VI and VII was obtained in three phage vectors with $15 \mathrm{~kb}$ long inserts each. The mouse Vti1a gene locus is at least $50 \mathrm{~kb}$ long and may be more compact then the Vtila region of human DNA having altogether $370 \mathrm{~kb}$. The characterised mouse Vtilb genomic region has $15 \mathrm{~kb}$ in length for exons III-VI and is of similar size in comparison to the complete human Vtilb locus with $23 \mathrm{~kb}$ in length (fig $37)$.

\subsubsection{Phenotypic heterogeneity of Vti1b deficient mice}

There were two pools of Vtilb deficient mice, mice of normal size and small Vtilb deficient mice. Both types are fertile. Normal size mice have no higher postnatal lethality than wild type mice. Small mice had a critical point in their life that was reached at about three weeks. In that time they had to start to be self-dependent in their feeding. Some of small Vtilb deficient mice do not survive that critical point. The weight of small mice stayed reduced in comparison with control littermates during the complete postnatal 
period. These small Vtilb deficient mice have reduced amounts of body fat. There were no detectable skeletal abnormalities in normal size and small Vtilb deficient mice.

Several knockout studies have shown phenotypically manifested dwarfism. A targeted disruption of the insulin - like growth factor II (IGF-II) causes decreasing of body weight till 60\% of wild type littermates even on heterozygous level (DeChiara et al. 1990). A knockout of thyroid hormone $\alpha 1$ receptor causes increased mortality and dwarfism in mice (Kaneshige et al. 2001). These studies describe an obligatory phenotype, where all descendants are affected and show reduced weight in comparison to wild type mice. LAMP2 knockout study provides an example of phenotypical heterogeneity, observed also in the case of Vtilb deficiency. LAMP-2 deficient mice have an increased mortality and loss of weight (Tanaka et al. 2000). About 50\% of the LAMP-2 deficient animals died between postnatal day 20 and 40. In addition, LAMP-2 deficient mice are smaller then the wild type. The weight difference is maximal (35-40\%) between day 20 and 30. In older mice (over 60 days) the weight difference is $10-15 \%$. The situation in LAMP-2 deficiency resembles in this aspect that in Vtilb deficiency. Some Vtilb knockout mice $(17,3 \%$ of the total number) stay smaller than their littermates, whereas some of then died. However, reasons for reduced size and body weights in some Vtilb knockout mice are unknown so far and have to be investigated. Retardation in fusion with lysosomes may contribute to this phenotype (see 5.1.4).

\subsubsection{Syntaxin 8 protein levels in deficient cells and tissues}

The only clear difference, distinguishing Vtilb deficient from control mice is in syntaxin8 protein levels.

Vtilb deficient mice had much less syntaxin 8 protein then control ones. This trait was found in all small and normal size Vtilb knockout mice and was seen by wetern blotting of different tissues and of MEFs as well as by immunofluorescent localisation of syntaxin 8 in MEFs. Reduction in syntaxin 8 amounts could be seen already in heterozygotic Vtilb mice (+/-), and therefore it was correlated with the gene-dosis effect of Vtilb expression in these mice. Syntaxin 8 is one of three partners of Vtilb in a SNARE complex, including also syntaxin 7 and endobrevin (Antonin et al. 2000a). The amounts of syntaxin 7 and endobrevin in Vtilb deficient mice were unchanged in comparison to control mice. Comparing neuronal and endosomal SNARE complexes Vtilb and syntaxin 8 take the 
position of both neuronal SNAP-25 helixes in the endosomal complex. Vtilb was equivalent to the $\mathrm{N}$-terminal helix of SNAP-25, syntaxin 8 - to the $\mathrm{C}$-terminal one (Antonin et al. 2002). Although truncated and/or partial complexes can be generated for the neuronal complex, they are less stable than the ternary complex (Calakos et al. 1994; Hayashi et al. 1994). However, all four endosomal SNAREs were required to form a stable, folded complex (Antonin et al. 2000a).

The expression of syntaxin $8 \mathrm{mRNA}$ is unaffected in Vtilb deficient mice, therefore it is likely that the syntaxin 8 protein is degraded. It is possible that due to the lack of Vtilb, syntaxin 8 is unable to form a complex and is available for the proteolytic machinery in the monomeric form. Another possibility is that Vtilb is required for the localisation of syntaxin 8 . In the absence of Vtilb the mislocalized syntaxin8 may be subject to proteolysis. As syntaxin 7 and endobrevin were stable in the absence of Vti $1 \mathrm{~b}$ these data indicate that the closest relationship within the complex is between Vtilb and syntaxin8. Some knockout studies of proteins involved in membrane transport also point to secondary changes in protein expression. RIM1 $\alpha$ is an active zone protein that was identified as a putative effector for the synaptic vesicle protein Rab3A. RIM1 $\alpha$ forms a protein scaffold for regulating neurotransmitter release at active zones. When RIM1 $\alpha$ is deleted, Munc13-1 shows a change in the protein amount, decreasing by about $60 \%$ in the knockout mice. Presumably it happens because Munc13-1 binds to RIM1 $\alpha$ and becomes destabilized in its absence. An isoform Munc13-3 was moderately affected. An additional isoform of Munc13-1, Munc13-2 that does not bind RIM1 $\alpha$ showed no decrease. Similarly to changes in syntaxin 8 levels in our case, RIM1 $\alpha$ heterozygous mice also showed decrease in Munc13-1 expression (Schoch et al. 2002).

A similar situation was observed in a Rab3A knockout study. Rabphilin-3A is a peripheral membrane protein of synaptic vesicles, which binds $\mathrm{Ca}^{2+}$ and phospholipids. Rab3A or Rab3C recruit rabphilin-3A to the synaptic vesicle membrane. In Rab3A knockout mice, the steady-state concentration of rabphilin-3A is decreased by $70 \%$ in spite of normal mRNA levels. The immunoblot data are also confirmed by immunofluorescence. In the absence of Rab3A or Rab3C isoforms, rabphilin-3A fails to reach the synapse and is degraded (Li et al. 1994).

Mice lacking the $\delta$ subunit of the AP-3 complex due to its targeted disruption show no detectable protein levels of the other subunits $\beta 3, \mu 3, \sigma 3$, belonging to the AP-3 complex. 
These three subunits of the AP-3 complex became presumably unstable and rapidly degraded (Kantheti et al. 1998).

An abolishment of $\mu 1 \mathrm{~A}$-adaptin leads to reduction in amounts of other AP1 complex members, namely $\gamma$ - and $\sigma 1$-adaptins. $\gamma$ - adaptin protein levels were reduced to $70 \%$ of control and $\sigma 1$-adaptin to $30 \%$ of wild type. On the mRNA expression level there were no changes observed for both of genes (Meyer et al. 2000). A parallel to syntaxin8 reduction can be drawn in these cases. Vtilb and syntaxin 8 are members of SNARE complexes while adaptins are members of adaptor complexes. However, an adaptor complex remains assembled, while SNARE complexes undergo cycles of assembly and disassembly during the fusion reaction. Transient interactions are also typical for RIM1 $\alpha$ and Munc13 and for Rab3A and rabphilin.

\subsubsection{Retardation of endosomal cargo delivery to lysosomes in Vti1b deficient hepatocytes}

Transport to the lysosome was analysed in Vtilb deficient mice. Binding of the ligand EGF induces endocytosis of the EGF-EGF-R complex, transport via the early and late endosome to the lysosome and lysosomal degradation. Hepatocytes from normal size Vtilb knockout mice had only a moderate retardation of EGF-R degradation, whereas degradation of the EGF-receptor was significantly slowered in hepatocytes from small Vtilb deficient mice. Degradation of asialofetuin is also a marker for the endocytic pathway and lysosomal degradation. ASGP-R is recycled each time to cell surface to enter a new cycle of endocytosis, but the internalised ligand asialofetuin is transported to lysosomes for degradation. Hepatocytes of normal size Vtilb knockout mice degraded asialofetuin with a similar kinetic as wild type cells, but the rate was reduced in hepatocytes of small Vtilb deficient mice. Cathepsin D is transported from the TGN via the late endosomes to lysosomes. Hepatocytes of small Vtilb knockout mice had a slightly retarded processing of cathepsin D precursor to the intermediate form. Cathepsin D processing was normal in hepatocytes derived from normal size Vtilb deficient mice. These data fit with electronmicrographs of hepatocytes. Wild type and Vtilb deficient hepatocytes from normal size mice were indistinguishable. Abnormalities were observed in hepatocytes derived from small Vtilb deficient mice. The number of multivesicular late endosomes and of autophagosomes was higher than in wild type hepatocytes. Quite often autophagosomes were in close contact with each other or with multivesicular bodies and 
were in the process of fusion. These structures are not seen in wild type hepatocytes. These observations are consistent with the model that SNAREs are not required for docking, but in a late step during membrane fusion.

Together these data indicate that fusion with lysosomes was slowed down but not completely abolished in hepatocytes of small vtilb deficient mice. Retardation in autophagocytosis and in transport to the lysosome in hepatocytes may compromise liver function. As the liver has a central role in the metabolism of mammals this may lead to reduced growth rates. LAMP-2 deficient mice are also smaller and show delays in autophagocytosis (Tanaka et al. 2000). However, these defects were not observed in the majority of vtilb deficient mice.

\subsubsection{Comparison of membrane traffic in Vti1b-deficient cells with in vitro studies of endosomal trafficking}

Works of several groups showed that Vti1b, syntaxin 7, syntaxin 8 and endobrevin participate in endosomal trafficking.

Syntaxin 7 associates with endobrevin (VAMP-8) and is specifically required for the fusion of late endosomes in vitro. Antibodies against syntaxin 7 inhibit fusion of late endosomes with lysosomes (Mullock et al. 2000). Expression of mutant syntaxin 7 lacking the transmembrane domain alters the morphology and distribution of endosomes and blocks endocytic transport to late endosomes (Nakamura et al. 2000). Homotypic lysosome fusion is in vitro inhibited by syntaxin 7 antibodies in dose-dependent manner (Ward et al. 2000).

VAMP-8 antibodies inhibit homotypic fusion of both early and late endosomes (Antonin et al. 2000b). It is possible that syntaxin 7 participates in two different SNARE complexes. Using B16 melanoma cells, it was shown that syntaxin 7 coimmunoprecipitates with Vtilb, syntaxin 6, VAMP8 as well as VAMP7 (Wade et al. 2001).

It has been proposed that syntaxin 7 and syntaxin 8 mediate distinct steps of endosomal protein trafficking. Syntaxin 7 is mainly localized to early endosomes and may be involved in protein trafficking from the PM to the EE. Syntaxin 8 is supposed to mediate clathrin independent step of transport from EE to LE. In permeabilised HeLa cells antibodies against syntaxin 8 retard transport of EGF to lysosome, but have no effect on recycling of transferrin receptor between plasma membrane early endosome and recycling endosome (Prekeris et al. 1999). Syntaxin 8 was found on early and late endosomes in PC12 and 
COS7-cells and clearly on TGN (Prekeris et al. 1999). Another group localised syntaxin 8 in NRK cells to early endosomes. Small fractions were found on late endosomes, plasma membrane and coated pits. It was shown that syntaxin 8 coimmunoprecipitates with Vti1rp1 (Vtilb) (Subramaniam et al. 2000).

However, other data indicate that syntaxin7 and syntaxin8 act in a common step. It was shown that Vtilb, syntaxin 8, syntaxin 7 and endobrevin are members of the same SNARE complex. Endocytic transport and lysosomal degradation of EGF was retarded by Fab fragments specific for endobrevin, Vti1b, syntaxin 7 and syntaxin 8. In addition, antisera directed against Vti1b, syntaxin7 and syntaxin8 inhibited fusion of late endosomes but not of early endosomes in vitro (Antonin et al. 2000a). The crystal structure of the complex consisting of the SNARE motifs of Vtilb, endobrevin, syntaxin 7 and syntaxin 8 was solved recently (Antonin et al. 2002). It is remarkably similar to the crystal structure of the neuronal SNARE complex. Our data show that Vti1b deficient hepatocytes from small mice have a retardation in delivery of endosomal cargo to the lysosome. This supports a role of characterised SNARE complex in late endosomal fusion.

\subsubsection{What may be reasons for the phenotypic heterogeneity of Vtilb deficient mice?}

The phenotype of Vtilb deficient mice may be heterogenous because they are genetically heterogenous. The E-14 embryonic stem cells used in the present work have the genetic background Sv129Ole (Hooper et al. 1987). Vti1b heterozygous mice were obtained by crossing germ-line producing chimeras with C57BL mice. Afterwards, the mice were crossed among each other. Hence Vti1b knockout mice have genetic information from both mouse strains, Sv129Ole and C57BL.

Given that there is only a mild phenotype in some mice and no detectable defects in most Vtilb deficient mice the question arises what compensational mechanism can exist? One possibility would be that other SNARE proteins can substitute for the absent Vtilb and the reduced syntaxin 8 and form a late endosomal complex together with syntaxin 7 and endobrevin. This hypothesis would explain why syntaxin 7 and endobrevin (VAMP8) are not degraded in Vtilb deficient tissues. Several SNAREs have been shown to form multiple core complexes in vivo, and many SNAREs bind to each other in vitro after tissue solubilisation. Furthermore, recombinant purified SNAREs can bind to each other in certain combination in vitro, although the stability of the complexes greatly varies (Jahn 
and Sudhof 1999). SNARE complexes always require four helices, one from each subfamily. Many SNAREs are already known and classified onto SNARE subfamilies. Vtilb is a Qb SNARE, syntaxin 8 is Qc SNARE (Bock et al. 2001). Therefore we have to search for possible candidates among known Qb and Qc SNAREs.

The first and best candidate could be SNAP-29, because it has both Qb and Qc SNARE motifs and can in this case act as Qb and Qc SNARE. SNAP-29 is predominantly soluble and its function in membrane traffic and SNARE partners remain unclear. SNAP-29 does not coimmunoprecipitate with syntaxin 7 and endobrevin in wild type cells (Antonin et al. 2000a). However, SNAP-29 shares only $24,6 \%$ amino acid identity with Vtilb and $28,1 \%$ with syntaxin 8 in the SNARE motif (Antonin et al. 2000a).

Second candidates could be Vtila (Qb) and syntaxin 6 (Qc). They coimmunoprecipitate together with VAMP4 and syntaxin 16 and form a SNARE complex of conserved structure because one SNARE motif of each subgroup is present. The complex may play a role in early endosomal fusion (Kreykenbohm et al. 2002). Experiments of Mallard et al. provide interaction data suggesting the formation of a specific SNARE complex between syntaxin 6, syntaxin 16 and Vtila. By coimmunoprecipitation it was shown that syntaxin 6/syntaxin 16/Vtila interact with either VAMP3/cellubrevin or VAMP4, but not with VAMP7TIVAMP of VAMP8/endobrevin. The authors state as unpublished data that syntaxin 6 but not syntaxin 5 stimulated binding of syntaxin 16 to GST-VAMP4 (Mallard et al. 2002). It is still possible that in the absence of its homologue and with reduced levels of syntaxin 8 Vtila and syntaxin 6 can form a lower affinity complex and participate in an additional fusion step. It is supported by the fact that syntaxin 6 is most homologous to syntaxin 8 (Subramaniam et al. 2000). Syntaxin 8 and syntaxin 6 share $32 \%$ amino acid identity in the SNARE motif (Steegmaier et al. 1998). As Vtila is distributed among several organelles small amounts are present in late endosomes. Vtilb and Vtila proteins have $39 \%$ of amino acid identity in the SNARE motif. An experiment using Vti1b knockout tissue homogenates could clarify whether SNAP-29 or Vtila/syntaxin 6 participate in a late endosomal complex together with syntaxin 7 and endobrevin.

Less plausible would be a participation of membrin $(\mathrm{Qb})$ and mbet1 $(\mathrm{Qc})$ in a late endosomal complex of Vtilb deficient cells. They do not participate in endosomal membrane traffic, but are involved in ER to Golgi transport as members of a SNARE complex with sec22b and syntaxin 5 (Xu et al. 2000). 
Always there is a possibility that yet undiscovered SNAREs or proteins which have not yet been characterised as SNAREs can participate in a late endosomal SNARE complex. Vti1b deficient mice of normal size may express substituting SNAREs at a higher level than small mice.

Another possibility is that completely different SNARE complex may fulfil the function of the endobrevin, syntaxin 7,Vti1b, syntaxin 8 complex and fuse late endosomes efficiently. This redundant SNARE complex should only have a minor role in the presence of Vtilb, because antibodies against Vtilb, syntaxin 7, syntaxin 8 and endobrevin reduced fusion of late endosomes in vitro by $75 \%$ (Antonin et al. 2000a). Wade et al. coimmunoprecipitated syntaxin 7 with Vtilb, endobrevin and small amounts of syntaxin 6. Authors propose that syntaxin 7/mVtilb/syntaxin 6 may form SNARE complexes with either VAMP7 or VAMP8 to regulate fusion events within the late endosomal pathway in melanoma cells (Wade et al. 2001).

In streptolysin-O-permeabilized cells, antibodies against VAMP-7 inhibit the breakdown of epidermal growth factor but not the recycling of transferrin (Advani et al. 1999). A significant proportion of VAMP7 was found in syntaxin 7 immunoprecipitate (Wade et al. 2001). A bacterially expressed human VAMP7 lacking the transmembrane domain inhibited both late endosome-lysosome fusion and homotypic lysosome fusion in vitro (Ward et al. 2000).These data support the hypothesis that another SNARE complex may in parallel regulate fusion of late endosomes. However, other SNAREs of this complex are not known so far. In small Vtilb deficient mice such compensation may be kept only at background levels for unknown reasons. The genetical background probably plays a role here. It is possible that cells of normal size Vtilb knockout mice express proteins of a parallel operating SNARE complex at higher level then cells of small Vtilb deficient mice do. It is also possible that the localisation of other SNAREs differs or that lysosomal transport works more efficient due to other components of the transport machinery and their regulation.

\subsubsection{Comparison of Vti1b deficiency to other knockout studies and an overview of existent organellar disease models}

There are several studies that utilise a knockout strategy to understand the role of particular SNARE proteins in membrane traffic and cellular metabolism. One of such studies was done to show whether VAMP-3 is required for GLUT4 recruitment to the cell surface. 
Enhanced glucose uptake in response to physiological stimuli was previously shown to recruit GLUT4 protein from intracellular vesicles to the cell surface (Lund et al. 1995; Olson et al. 1997). Several studies indicate that syntaxin4 and SNAP-23 on the plasma membrane are required for fusion of GLUT4 vesicles. These GLUT4 vesicles contain both VAMP2 and VAMP3/cellubrevin. To distinguish between the functional properties of VAMP2 and VAMP3 in that case, VAMP3 targeted disruption was applied. The data clearly demonstrate that VAMP3 absence has no significant effect on whole-body glucose metabolism or insulin-stimulated glucose uptake. Researchers found VAMP3 even dispensable for both insulin- and exercise-stimulated glucose uptake in vivo(Yang et al. 2001b). It is most likely that VAMP2 can compensate for the genetic loss of VAMP3 during muscle and adipose tissue development because VAMP2 and VAMP3 differ only in a single amino acid residue in the SNARE motif.

Another study was intended to show the role of syntaxin 4 for GLUT4 protein translocation after insulin stimulation. Syntaxin 4 deficient mice have early embryonic lethality, so it was impossible to study phenotypes in its full absence. Syntaxin 4 shares $42 \%$ amino acids identity with its closest homolog syntaxin1B, but syntaxin1B which is expressed predominantly in neurons cannot complement for the loss of syntaxin4. A lack of complementation by related protein may be due to expression patterns, localisation or failure to interact with other components of the fusion machinery. Heterozygous syntaxin 4 mice have $40 \%$ less syntaxin 4 and were shown to develop insulin resistance, as manifested by significant decreases in rates of whole-body glucose disposal and glycolysis. The decrease in insulin- stimulated skeletal muscle glucose uptake occurred in parallel with a reduction in GLUT4 translocation. So syntaxin4 was shown to be important in GLUT4 translocation in skeletal muscle (Yang et al. 2001a).

An aim of another study of a SNARE protein was to show the role of synaptobrevin 2 in synaptic transmission. Synaptobrevin 2 (VAMP2) knockout mice die immediately after birth. It was still possible to study a role of that protein in cultured hippocampal neurons using electrophysiological methods. In the absence of synaptobrevin 2, spontaneous synaptic vesicle fusion and fusion induced by hypertonic sucrose were decreased $\sim 10$ fold, but fast $\mathrm{Ca}^{2+}$-triggered fusion was decreased more than 100-fold. Thus, synaptobrevin 2 may function in catalysing fusion reactions and stabilizing fusion intermediates but may not absolutely be required for synaptic vesicle fusion (Schoch et al. 2001). The R-SNARE 
VAMP4 which is also localised to synaptic vesicles (Kreykenbohm et al. 2002) may substitute for synaptobrevin.

Currently several human diseases and mouse mutants are described that are supposed to be connected to the formation of lysosomes and lysosome-related organelles. Most of these disorders are accompanied by abnormal pigmentation. Lysosomes are morphologically heterogeneous, often resembling other organelles of the endocytic and secretory pathways. Therefore, they are currently distinguished from other organelles on the basis of an operational definition, which describes them as membrane-bound acidic organelles that contain mature acid-dependent hydrolases and LAMPs but lack mannose 6-phosphate receptors (MPRs). Properties of lysosomes are shared with a group of cell-type specific compartments referred as "lysosome-related organelles", which include melanosomes, lytic granules, MHC class II compartments, platelet-dense granules, basophil granules, azurophil granules and Drosophila pigment granules. Mouse mutants can be good models to study human diseases.

The mocha mutant has defect melanosomes, abnormal lysosomes and platelet dense granules. This mutant is a model for type 2 of Hermansky-Pudlak syndrome, which is also characterised by neurological defects. Mutation in AP-3 $\delta$ in the mocha mouse links endosomal transport to storage deficiency in platelets, melanosomes and synaptic vesicles (Kantheti et al. 1998).

Defects in platelet dense granules and pigmentation characterise the mouse mutant pallid (pa).This mutant is probably defective in a more downstream event of vesicle trafficking vesicle docking and fusion. The affected protein termed pallidin interacts with syntaxin 13 . Participation of syntaxin 13 in endosomal trafficking was described by two independent groups (Advani et al. 1998; Prekeris et al. 1998). The level of syntaxin 13 is reduced approximately $50 \%$ in $p a$ animals compared to $\mathrm{C} 57 \mathrm{BL} / 6 \mathrm{~J}$ mice. The mRNA level is not affected, suggesting that loss of pallidin may lead to instability of syntaxin 13 (Huang et al. 1999). In this type of storage pool deficiency (SPD) reduction of syntaxin 13 amounts resembles destabilization of syntaxin 8 studied in this work.

Enlarged melanosomes have also been described for pale ear melanocytes. Ammonia induced secretion of lysosomal hydrolases is defective in pale ear fibroblasts (Brown et al. 1985). 
A characteristic feature of Chediak-Higashi syndrome at the cellular level is the presence of giant lysosomes, melanosomes, MIIC, lytic granules and azurophil granules. Mouse model for Chediak-Higashi syndrome is the beige mouse strain that carries a mutation in the LYST/Beige protein.

Abnormal organelle morphology also has been reported for neuroectodermal melanolysosomal disease (Elejalde et al. 1979). Even though they seem not to be connected to SNAREs directly, they show the importance of having proper lysosomal function.

\subsubsection{Outlook}

Vtilb deficient mice are good model to study late endosomal trafficking. A central goal of later studies should be to determine the reasons for compensatory mechanisms of Vtilb deficiency.

To get rid of the genetical heterogeneity of the Vtilb deficient mice they could be crossed back to Sv129Ole mice or to C57BL mice. Both crossings are going on at this time. If the heterogeneity is due to the genetic background, this would lead to increasing numbers of small mice in later generations of deficient mice of either genetic background. Immunoprecipitation of SNARE complexes from knockout tissue homogenates have to be done using antibodies directed against syntaxin 7 and directed against the putative novel partners SNAP-29, Vtila and syntaxin 6. Expression of other SNAREs has to be examined in more detail to find out if their levels are changed in deficient tissues. More attention should be paid to liver pathologies of these mice. The question why only some mice stay smaller than their littermates is still open and should be answered. Degradation of longlived proteins has to be examined in hepatocytes of small mice. Interesting could be the comparison of syntaxin 7 as well as endobrevin localisation in cells from wild type, Vtilb deficient mice of normal size and of small size using electron microscopy. If novel SNAREs are recruited into a SNARE complex with syntaxin 7 it should be analysed whether their subcellular distribution is changed. An in vitro late endosomal fusion assay established from wild type as well as Vtilb deficient embryonic fibroblasts, would be helpful to determine which complex in cells of normal size mice operates in that fusion step. 


\section{Summary}

Genomic DNA for Vtilb and Vtila was isolated and the chromosomal regions characterised. Using targeted gene disruption mouse mutants lacking Vtilb constitutively were generated. It was shown that Vtilb was a non-essential protein. The absence of Vtilb reduced the levels of syntaxin 8 protein in all cells and tissues while syntaxin 8 mRNA levels remained unchanged. Vtilb knockout had phenotypic heterogeneity which was manifested by the appearance of mice of normal and small size. Normal size Vtilb knockout mice showed no detectable defects in late endosomal trafficking, whereas hepatocytes from small ones displayed a retardation in cargo transport from late endosomes to lysosomes marked by slower EGF-R degradation, delayed asialofetuin degradation and reduced cathepsin D maturation. Electron microscopic data showed that the number of multivesicular late endosomes and of autophagosomes was higher in hepatocytes of small Vtilb deficient mice, quite often autophagosomes were in close contact and were in the process of fusion. That was not observed in hepatocytes of wild type and normal size Vtilb deficient mice.

It was also shown that the Vtila chromosomal region is at least three times larger than the Vtilb locus. Two targeting DNA constructs were generated utilising two different knockout strategies for obtaining Vtila deficient mice. Two embryonic stem cell clones carrying a constitutively mutated Vtila gene copy were selected and used for obtaining chimeric mice. 


\section{$7 \quad$ References}

Advani, R. J., H. R. Bae, J. B. Bock, D. S. Chao, Y. C. Doung, et al. (1998). "Seven novel mammalian SNARE proteins localize to distinct membrane compartments." Journal of Biological Chemistry 273: 10317-10324.

Advani, R. J., B. Yang, R. Prekeris, K. C. Lee, J. Klumperman, et al. (1999). "VAMP-7 mediates vesicular transport from endosomes to lysosomes.” Journal of Cell Biology 146: 765-775.

Ahle, S. and E. Ungewickell (1989). "Identification of a clathrin binding subunit in the HA2 adaptor protein complex." Journal of Biological Chemistry 264(33): 20089-93.

Alwine, J. C., D. J. Kemp and G. R. Stark (1977). "Method for detection of specific RNAs in agarose gels by transfer to diazobenzyloxymethyl-paper and hybridization with DNA probes." Proceedings of the National Academy of Sciences of the United States of America 74(12): 5350-4.

Anderson, R. G., J. L. Goldstein and M. S. Brown (1976). "Localization of low density lipoprotein receptors on plasma membrane of normal human fibroblasts and their absence in cells from a familial hypercholesterolemia homozygote." Proceedings of the National Academy of Sciences of the United States of America 73(7): 2434-8.

Antonin, W., D. Fasshauer, S. Becker, R. Jahn and T. Schneider (2002). "Crystal structure of the endosomal SNARE complex reveals common structural principles of all SNAREs.” Nat. Struct. Biol. 9: 107-111.

Antonin, W., C. Holroyd, D. Fasshauer, S. Pabst, G. Fischer von Mollard, et al. (2000a). "A SNARE complex mediating fusion of late endosomes defines conserved properties of SNARE structure and function.” EMBO Journal 19: 6453-6464.

Antonin, W., C. Holroyd, R. Tikkanen, S. Höning and R. Jahn (2000b). “The R-SNARE endobrevin/VAMP-8 mediates homotypic fusion of early and late endosomes." Mol. Biol. Cell 11: 3289-3298. 
Antonin, W., D. Riedel and G. Fischer von Mollard (2000c). "The SNARE Vtila-ß3 is localized to small synaptic vesicles and participates in a novel SNARE complex.” J. Neurosc. 20: 5724-5732.

Baba, M., M. Osumi and Y. Ohsumi (1995). "Analysis of the membrane structures involved in autophagy in yeast by freeze-replica method." Cell Structure and Function 20(6): 465-71.

Bednarek, S. Y., L. Orci and R. Schekman (1996). "Traffic COPs and formation of vesicle coats." Trends in Cell Biology 6: 468-473.

Berger, S. L. (1984). "The use of Cerenkov radiation for monitoring reactions performed in minute volumes: examples from recombinant DNA technology.” Analytical Biochemistry 136(2): 515-9.

Bock, J. B., H. T. Matern, A. A. Peden and R. H. Scheller (2001). “A genomic perspective on membrane compartment organization." Nature 409: 839-841.

Breitfeld, P. P., C. F. Simmons, G. J. Strous, H. J. Geuze and A. L. Schwartz (1985). “Cell biology of the asialoglycoprotein receptor system: a model of receptor-mediated endocytosis.” International Review of Cytology 97: 47-95.

Brown, J. A., E. K. Novak and R. T. Swank (1985). "Effects of ammonia on processing and secretion of precursor and mature lysosomal enzyme from macrophages of normal and pale ear mice: evidence for two distinct pathways." Journal of Cell Biology 100(6): 1894-904.

Brown, M. S., R. G. Anderson, S. K. Basu and J. L. Goldstein (1982). "Recycling of cellsurface receptors: observations from the LDL receptor system." Cold Spring Harbor Symposia On Quantitative Biology 46 Pt 2: 713-21.

Brown, M. S. and J. L. Goldstein (1976). "Receptor-mediated control of cholesterol metabolism." Science 191(4223): 150-4.

Bruns, D. and R. Jahn (2002). “Molecular determinants of exocytosis.” Eur J Physiol 443: 333-338.

Calakos, N., M. K. Bennett, K. E. Peterson and R. H. Scheller (1994). "Protein-protein interactions contributing to the specificity of intracellular vesicular traffic." Science 263: 1146-1149. 
Cao, X., N. Ballew and C. Barlowe (1998). "Initial docking of ER-derived vesicles requires Uso $1 p$ and Yptlp but is independent of SNARE proteins.” EMBO Journal 17: 2156-2165.

Colombo, M. I., W. Beron and P. D. Stahl (1997). "Calmodulin regulates endosome fusion." Journal of Biological Chemistry 272(12): 7707-12.

Cooper, T. G. (1981). Biochemische Arbeitsmetoden. Berlin, New York, Walter de Gruyter.

de_Chastellier, C., A. Ryter and L. Thilo (1983). "Membrane shuttle between plasma membrane, phagosomes, and pinosomes in Dictyostelium discoideum amoeboid cells." European Journal of Cell Biology 30(2): 233-43.

DeChiara, T. M., A. Efstratiadis and E. J. Robertson (1990). “A growth-deficiency phenotype in heterozygous mice carrying an insulin-like growth factor II gene disrupted by targeting." Nature 345(6270): 78-80.

Dilcher, M., B. Köhler and G. Fischer von Mollard (2001). "Genetic interactions with the yeast Q-SNARE VTI1 reveal novel functions for the R-SNARE YKT6.” Journal of Biological Chemistry 276: 34537-34544.

Dunant, Y. and M. Israel (1998). "In vitro reconstitution of neurotransmitter release." Neurochemical Research 23(5): 709-18.

Dunn, W. A. and A. L. Hubbard (1984). "Receptor-mediated endocytosis of epidermal growth factor by hepatocytes in the perfused rat liver: ligand and receptor dynamics." Journal of Cell Biology 98(6): 2148-59.

Elejalde, B. R., J. Holguin, A. Valencia, E. F. Gilbert, J. Molina, et al. (1979). “Mutations affecting pigmentation in man: I. Neuroectodermal melanolysosomal disease.” American Journal of Medical Genetics 3(1): 65-80.

Fasshauer, D., W. Antonin, M. Margittai, S. Pabst and R. Jahn (1999). "Mixed and noncognate SNARE complexes." Journal of Biological Chemistry 274: 1544015446.

Fasshauer, D., W. Eliason, A. Brunger and R. Jahn (1998a). "Identification of a minimal core of the synaptic SNARE complex sufficient for reversible assembly and disassembly." Biochemistry 37: 10354-10362.

Fasshauer, D., R. B. Sutton, A. T. Brunger and R. Jahn (1998b). "Conserved structural features of the synaptic fusion complex: SNARE proteins reclassified as Q- and 
R-SNAREs.” Proceedings of the National Academy of Sciences of the United States of America 95: 15781-15786.

Feinberg, A. P. and B. Vogelstein (1983). “A technique for radiolabeling DNA restriction endonuclease fragments to high specific activity." Analytical Biochemistry 132(1): 6-13.

Fengsrud, M., E. S. Erichsen, T. O. Berg, C. Raiborg and P. O. Seglen (2000). "Ultrastructural characterization of the delimiting membranes of isolated autophagosomes and amphisomes by freeze-fracture electron microscopy." European Journal of Cell Biology 79(12): 871-82.

Fischer von Mollard, G., S. F. Nothwehr and T. H. Stevens (1997). “The yeast v-SNARE Vtilp mediates two vesicle transport pathways through interactions with the tSNAREs Sed5p and Pep12p.” Journal of Cell Biology 137: 1511-1524.

Fischer von Mollard, G. and T. H. Stevens (1998). “A Human homolog can functionally replace the yeast v-SNARE Vtilp in two vesicle transport pathways.” Journal of Biological Chemistry 273: 2624-2630.

Fischer von Mollard, G. and T. H. Stevens (1999). "The Saccharomyces cerevisiae vSNARE Vtilp is required for multiple membrane transport pathways to the vacuole.” Mol. Biol. Cell 10: 1719-1732.

Fukuda, R., J. Mc New, T. Weber, F. Parlati, T. Engel, et al. (2000). "Functional architecture of an intracellular membrane t-SNARE." Nature 407: 198-202.

Govindan, B., R. Bowser and P. Novick (1995). "The role of Myo2, a yeast class V myosin, in vesicular transport." Journal of Cell Biology 128(6): 1055-1068.

Grote, E., C. Carr and P. Novick (2000). "Ordering the final events in yeast exocytosis." Journal of Cell Biology 151: 439-452.

Harvey, W. R. and H. Wieczorek (1997). “Animal plasma membrane energization by chemiosmotic H+ V-ATPases.” Journal of Experimental Biology 200 ( Pt 2): 203-16.

Hayashi, T., H. McMahon, S. Yamasaki, T. Binz, Y. Hata, et al. (1994). "Synaptic vesicle membrane fusion complex: action of clostridial neurotoxins on assembly." EMBO Journal 13(21): 5051-5061. 
Henell, F., A. Berkenstam, J. Ahlberg and H. Glaumann (1987). "Degradation of shortand long-lived proteins in perfused liver and in isolated autophagic vacuoles-lysosomes." Experimental and Molecular Pathology 46(1): 1-14.

Hirst, J. and M. S. Robinson (1998). “Clathrin and adaptors.” Biochimica Et Biophysica Acta 1404(1-2): 173-93.

Hooper, M., K. Hardy, A. Handyside, S. Hunter and M. Monk (1987). “HPRT-deficient (Lesch-Nyhan) mouse embryos derived from germline colonization by cultured cells." Nature 326(6110): 292-5.

Huang, L., Y. M. Kuo and J. Gitschier (1999). “The pallid gene encodes a novel, syntaxin 13-interacting protein involved in platelet storage pool deficiency." Nature Genetics 23(3): 329-32.

Huizing, M., Y. Anikster and W. A. Gahl (2000). "Hermansky-Pudlak syndrome and related disorders of organelle formation." Traffic 1(11): 823-35.

Jahn, R. and T. Sudhof (1999). "Membrane fusion and exocytosis.” Annu. Rev. Biochem 68: $863-911$.

Kane, P. M. and K. J. Parra (2000). “Assembly and regulation of the yeast vacuolar H(+)ATPase.” Journal of Experimental Biology 203 Pt 1: 81-7.

Kaneshige, M., H. Suzuki, K. Kaneshige, J. Cheng, H. Wimbrow, et al. (2001). “A targeted dominant negative mutation of the thyroid hormone $\alpha 1$ receptor causes increased mortality, infertility, and dwarfism in mice." Proceedings of the National Academy of Sciences of the United States of America 98(26): 1509515100.

Kantheti, P., X. Qiao, M. E. Diaz, A. A. Peden, G. E. Meyer, et al. (1998). "Mutation in AP-3 delta in the mocha mouse links endosomal transport to storage deficiency in platelets, melanosomes, and synaptic vesicles.” Neuron 21: 111-122.

Kasper, D., F. Dittmer, K. von_Figura and R. Pohlmann (1996). "Neither type of mannose 6-phosphate receptor is sufficient for targeting of lysosomal enzymes along intracellular routes." Journal of Cell Biology 134(3): 615-23.

Kirchhausen, T. (2000). “Clathrin.” Annual Review of Biochemistry 69: 699-727.

Klein, G. and M. Satre (1986). "Kinetics of fluid-phase pinocytosis in Dictyostelium discoideum amoebae." Biochemical and Biophysical Research Communications 138(3): 1146-52. 
Klumperman, J., A. Hille, T. Veenendaal, V. Oorschot, W. Stoorvogel, et al. (1993).

"Differences in the endosomal distributions of the two mannose 6-phosphate receptors." Journal of Cell Biology 121(5): 997-1010.

Kornfeld, S. and I. Mellman (1989). “The biogenesis of lysosomes.” Ann. Rev. Cell Biol. 5: $483-525$.

Kreykenbohm, V., D. Wenzel, W. Antonin, V. Atlachkine and G. Fischer von Mollard (2002). "The SNAREs vtila and vtilb have distinct localization and SNARE complex partners." European Journal of Cell biology 81: 273-280.

Lazar, T., M. Götte and D. Gallwitz (1997). "Vesicular transport: how many Ypt/RabGTPases make a eukaryotic cell.” Trends Biochem. 22: 468-472.

Le_Borgne, R. and B. Hoflack (1998). "Protein transport from the secretory to the endocytic pathway in mammalian cells.” Biochimica Et Biophysica Acta 1404(1-2): 195-209.

Lentz, B. R., V. Malinin, M. E. Haque and K. Evans (2000). "Protein machines and lipid assemblies: current views of cell membrane fusion." Current Opinion in Structural Biology 10(5): 607-15.

Li, C., K. Takei, M. Geppert, L. Daniell, K. Stenius, et al. (1994). "Synaptic targeting of rabphilin-3A, a synaptic vesicle $\mathrm{Ca} 2+/$ phospholipid-binding protein, depends on rab3A/3C." Neuron 13(4): 885-98.

Lund, S., G. D. Holman, O. Schmitz and O. Pedersen (1995). "Contraction stimulates translocation of glucose transporter GLUT4 in skeletal muscle through a mechanism distinct from that of insulin." Proceedings of the National Academy of Sciences of the United States of America 92(13): 5817-21.

Lupashin, V. V., I. D. Pokrovskaya, J. A. McNew and M. G. Waters (1997). "Characterization of a novel yeast SNARE protein implicated in Golgi retrograde traffic." Mol. Biol. Cell 8: 2659-2676.

Mallard, F., B. Tang, T. Galli, D. Tenza, A. Saint-Pol, et al. (2002). "Early/recycling endosomes-to-TGN transport involves two SNARE complexes and a Rab6 isoform.” Journal of Cell Biology 156: 653-664.

Martinez, O. and B. Goud (1998). "Rab proteins." Biochim. Biophys. Acta 1404: 101-112. Mayer, A. (2001). "What drives membrane fusion in eucaryotes?" Trends in Biochemical Sciences 26(12): 717-723. 
Mayer, A. and W. Wickner (1997). "Docking of yeast vacuoles is catalyzed by the Ras-like GTPase Ypt7p after symmetric priming by Sec18p (NSF).” Journal of Cell Biology 136(2): 307-17.

McNew, J. A., F. Parlati, R. Fukuda, R. J. Johnston, K. Paz, et al. (2000). “Compartimental specificity of cellular membrane fusion encoded in SNARE proteins." Nature 407: 153-158.

Melikyan, G. B., R. M. Markosyan, M. G. Roth and F. S. Cohen (2000). “A point mutation in the transmembrane domain of the hemagglutinin of influenza virus stabilizes a hemifusion intermediate that can transit to fusion." Molecular Biology of the Cell 11(11): 3765-75.

Meredith, M. J. (1988). "Rat hepatocytes prepared without collagenase: prolonged retention of differentiated characteristics in culture." Cell Biology and Toxicology 4(4): 405-25.

Meyer, C., D. Zizioli, S. Lausmann, E. L. Eskelinen, J. Hamann, et al. (2000). “mu1Aadaptin-deficient mice: lethality, loss of AP-1 binding and rerouting of mannose 6-phosphate receptors." EMBO Journal 19(10): 2193-203.

Molloy, S. S., E. D. Anderson, F. Jean and G. Thomas (1999). "Bi-cycling the furin pathway: from TGN localization to pathogen activation and embryogenesis." Trends Cell Biol 9(1): 28-35.

Montecucco, C. and G. Schiavo (1995). "Structure and function of tetanus and botulinum neurotoxins." Quarterly Reviews of Biophysics 28(4): 423-72.

Mukherjee, S., R. N. Ghosh and F. R. Maxfield (1997). “Endocytosis.” Physiological Reviews 77(3): 759-803.

Mullock, B. M., C. W. Smith, G. Ihrke, N. A. Bright, M. Lindsay, et al. (2000). "Syntaxin 7 is localized to late endosome compartments, associates with VAMP 8, and is required for late endosome-lysosome fusion.” Mol. Biol. Cell 11: 3137-3153.

Nakamura, N., A. Yamamoto, Y. Wada and M. Futai (2000). "Syntaxin 7 mediates endocytic traffic to late endosomes.” Journal of Biological Chemistry 275: 65236529.

Nichols, B. J. and J. Lippincott_Schwartz (2001). "Endocytosis without clathrin coats." Trends Cell Biol 11(10): 406-12. 
Niemann, H., J. Blasi and R. Jahn (1994). “Clostridial neurotoxins: new tools for dissecting exocytosis." Trends in Cell Biology 4: 179-185.

O_Halloran, T. J. and R. G. Anderson (1992). "Clathrin heavy chain is required for pinocytosis, the presence of large vacuoles, and development in Dictyostelium." Journal of Cell Biology 118(6): 1371-7.

Olson, A. L., J. B. Knight and J. E. Pessin (1997). "Syntaxin 4, VAMP2, and/or VAMP3/cellubrevin are functional target membrane and vesicle SNAP receptors for insulin-stimulated GLUT4 translocation in adipocytes." Molecular and Cellular Biology 17(5): 2425-35.

Parlati, F., J. A. McNew, R. Fukuda, R. Miller, T. H. Söllner, et al. (2000). “Topological restriction of SNARE-dependent membrane fusion." Nature 407: 194-198.

Peden, A., G. Park and R. H. Scheller (2001). “The Di-leucine motif of vesicle-associated membrane protein 4 is required for its localisation and AP-1 binding." Journal of Biological Chemistry 276(52): 49183-49187.

Peters, C., P. Andrews, M. Stark, S. Cesaro-Tadic, A. Glatz, et al. (1999). "Control of the terminal step of intracellular membrane fusion by protein phosphatase 1." Science 285: 1084-1087.

Peters, C., M. Bayer, S. Bühler, J. Andersen, M. Mann, et al. (2001). “Trans-complex formation by proteolipid channels in the terminal phase of membrane fusion." Nature 409: 581-588.

Peters, C. and A. Mayer (1998). " $\mathrm{Ca}^{2+} /$ calmodulin signals the completion of docking and triggers a late step in vacuole fusion." Nature 396: 575-580.

Pohlmann, R., M. W. Boeker and K. von_Figura (1995). “The two mannose 6-phosphate receptors transport distinct complements of lysosomal proteins.” Journal of Biological Chemistry 270(45): 27311-8.

Porat, A. and Z. Elazar (2000). "Regulation of intra-Golgi membrane transport by calcium.” Journal of Biological Chemistry 275(38): 29233-7.

Prekeris, R., J. Klumperman, Y. A. Chen and R. H. Scheller (1998). "Syntaxin 13 mediates cycling of plasma membrane proteins via tubulovesicular recycling endosomes." Journal of Cell Biology 143: 957-971. 
Prekeris, R., B. Yang, V. Oorschot, J. Klumperman and R. H. Scheller (1999).

"Differential roles of syntaxin 7 and syntaxin 8 in endosomal trafficking." Mol. Biol. Cell 10: 3891-3908.

Pryor, P. R., B. M. Mullock, N. A. Bright, S. R. Gray and J. P. Luzio (2000). "The role of intraorganellar $\mathrm{Ca}(2+)$ in late endosome-lysosome heterotypic fusion and in the reformation of lysosomes from hybrid organelles." Journal of Cell Biology 149(5): 1053-62.

Razinkov, V. I., G. B. Melikyan and F. S. Cohen (1999). "Hemifusion between cells expressing hemagglutinin of influenza virus and planar membranes can precede the formation of fusion pores that subsequently fully enlarge." Biophysical Journal 77(6): 3144-51.

Robinson, M. S. (1994). "The role of clathrin, adaptors and dynamin in endocytosis." Current Opinion in Cell Biology 6(4): 538-44.

Saiki, R. K., T. L. Bugawan, G. T. Horn, K. B. Mullis and H. A. Erlich (1986). “Analysis of enzymatically amplified beta-globin and HLA-DQ alpha DNA with allelespecific oligonucleotide probes." Nature 324(6093): 163-6.

Saiki, R. K., D. H. Gelfand, S. Stoffel, S. J. Scharf, R. Higuchi, et al. (1988). "Primerdirected enzymatic amplification of DNA with a thermostable DNA polymerase." Science 239(4839): 487-91.

Sambrook, J., E. F. Fritsch and T. Maniatis (1989). Molecular Cloning: A Laboratory Manual. Cold Spring Harbor, New York, Cold Spring Harbor Laboratory.

Scales, S. J., J. B. Bock and R. H. Scheller (2000). "The specifics of membrane fusion." Nature 407: 144-146.

Schmid, S. L. (1997). "Clathrin-coated vesicle formation and protein sorting: an integrated process." Annual Review of Biochemistry 66: 511-48.

Schoch, S., P. E. Castillo, T. Jo, K. Mukherjee, M. Geppert, et al. (2002). "RIM1 $\alpha$ forms a protein scaffold for regulating neurotransmitter release at active zone." Nature 415(17 January): 321-326.

Schoch, S., F. Deak, A. Königstorfer, M. Mozhayeva, Y. Sara, et al. (2001). “SNARE function analyzed in synaptobrevin/VAMP knockout mice.” Science 294: 1117 1122. 
Seglen, P. O. (1976). "Preparation of isolated rat liver cells." Methods in Cell Biology 13: 29-83.

Simmen, T., S. Höning, A. Icking, R. Tikkanen and W. Hunziker (2002). “AP-4 binds basolateral signals and participates in basolateral sorting in epithelial MDCK cells.” Nature Cell Biology 4(February): 154-159.

Sorkin, A. D., L. V. Teslenko and N. N. Nikolsky (1988). "The endocytosis of epidermal growth factor in A431 cells: a $\mathrm{pH}$ of microenvironment and the dynamics of receptor complex dissociation.” Experimental Cell Research 175(1): 192-205.

Southern, E. M. (1975). "Detection of specific sequences among DNA fragments separated by gel electrophoresis.” Journal of Molecular Biology 98(3): 503-17.

Steegmaier, M., B. Yang, J. Yoo, B. Huang, M. Shen, et al. (1998). “Thre novel proteins of the syntaxin/SNAP-25 family." Journal of Biological Chemistry 273: 3417134179.

Steinman, R. M., I. S. Mellman, W. A. Muller and Z. A. Cohn (1983). "Endocytosis and the recycling of plasma membrane." Journal of Cell Biology 96(1): 1-27.

Stromhaug, P. E. and D. J. Klionsky (2001). “Approaching the molecular mechanism of autophagy." Traffic 2(8): 524-31.

Subramaniam, V. N., E. Loh, H. Horstmann, A. Habermann, Y. Xu, et al. (2000). "Preferential association of syntaxin 8 with the early endosome." J. Cell Sci. 113: $997-1008$.

Sutton, R. B., D. Fasshauer, R. Jahn and A. T. Brunger (1998). "Crystal structure of a SNARE complex involved in synaptic exocytosis at $2.4 \AA$ resolution.” Nature 395: $347-353$.

Tanaka, Y., G. Guhde, A. Suter, E. Eskelinen, D. Hartmann, et al. (2000). “Accumulation of autophagic vacuoles and cardiomyopathy in LAMP-2-deficient mice." Nature 406: 902-906.

Thilo, L. and G. Vogel (1980). "Kinetics of membrane internalization and recycling during pinocytosis in Dictyostelium discoideum." Proceedings of the National Academy of Sciences of the United States of America 77(2): 1015-9.

Tolleshaug, H., T. Berg, M. Nilsson and K. R. Norum (1977). "Uptake and degradation of 125I-labelled asialo-fetuin by isolated rat hepatocytes." Biochimica Et Biophysica Acta 499(1): 73-84. 
Ungermann, C., K. Sato and W. Wickner (1998). "Defining the functions of trans-SNARE pairs." Nature 396: 543-548.

Ungermann, C., G. F. von_Mollard, O. N. Jensen, N. Margolis, T. H. Stevens, et al. (1999). "Three v-SNAREs and two t-SNAREs, present in a pentameric cisSNARE complex on isolated vacuoles, are essential for homotypic fusion." Journal of Cell Biology 145(7): 1435-42.

Wade, N., N. Bryant, L. Connolly, R. Simpson, J. Luzio, et al. (2001). "Syntaxin 7 complexes with mouse Vps10p tail interactor 1b, syntaxin 6, vesicle-associated membrane protein (VAMP)8, and VAMP7 in b16 melanoma cells.” Journal of Biological Chemistry 276: 19820-19827.

Ward, D., J. Pevsner, M. A. Scullion, M. Vaughn and J. Kaplan (2000). "Syntaxin 7 and VAMP-7 are SNAREs required for late endosome-lysosome and homotypic lysosome fusion in alveolar macrophages." Mol. Biol. Cell 11: 2327-2333.

Weimbs, T., K. Mostov, S. H. Low and K. Hofmann (1998). “A model for structural similarity between different SNARE complexes based on sequence relationships." Trends in Cell Biology 8: 260-262.

Wickner, W. (2002). "Yeast vacuoles and membrane fusion pathways.” EMBO Journal 21(6): 1241-1247.

Xu, D., A. P. Joglekar, A. L. Williams and J. C. Hay (2000). "Subunit structure of a mammalian ER/Golgi SNARE complex.” Journal of Biological Chemistry 275(50): 39631-9.

Xu, Y., S. H. Wong, B. L. Tang, V. N. Subramaniam, T. Zhang, et al. (1998). “A 29kilodalton Golgi soluble N-ethylmaleimide-sensitive factor attachment protein receptor (Vti1-rp2) implicated in protein trafficking in the secretory pathway." Journal of Biological Chemistry 273: 21783-21789.

Yang, B., L. Gonzalez, R. Prekeris, M. Steegmaier, R. J. Advani, et al. (1999). "SNARE proteins are not selective. Implications for membrane fusion specificity.” Journal of Biological Chemistry 274: 5649-5653.

Yang, C., K. J. Coker, J. K. Kim, S. Mora, D. C. Thurmond, et al. (2001a). "Syntaxin 4 heterozygous knockout mice develop muscle insulin resistance.” Journal of Clinical Investigation 107(10): 1311-8. 
Yang, C., S. Mora, J. W. Ryder, K. J. Coker, P. Hansen, et al. (2001b). "VAMP3 null mice display normal constitutive, insulin- and exercise-regulated vesicle trafficking." Molecular and Cellular Biology 21(5): 1573-80.

Zimmerberg, J. and L. V. Chernomordik (1999). "Membrane fusion.” Adv Drug Deliv Rev 38: $197-205$. 


\section{Acknowledgements}

I would like to express my gratitude to Prof. Dr. K.von Figura for his excellent supervision, helpful tips, advices and comments which led to successful experiments and important data.

I am grateful to Prof Dr. G. Gottschalk for co-reference.

A special acknowledgment to Dr. G. Fischer von Mollard for giving me the opportunity to do this work. This has been an exciting project for me and I thank her for guiding me. I have also benefitted from the stimulating discussions and her excellent supervision. I acknowledge her for the critical reading of the thesis.

Thanks also go to Eeva-Liisa Eskelinen, who did the electron microscopic studies of hepatocytes.

I acknowledge all employees and research workers of the Department of Biochemistry II for their cooperation. I gratefully acknowledge Dr. Peter Schu and Dr. Paul Saftig for their helpful advices and support.

I thank Elizabeth Munk and other workers of the animal house for their active support.

I thank Anna-Lena Illert for teaching me the art of liver perfusion.

I acknowledge Mike Dilcher, Beate Köhler and Nina Müllers for creating a healthy working atmosphere in our laboratory, with supportive advices, help, good spirits and humour.

I thank Vera Kreykenbohm for helping me to gain technical skills in handling Adobe Illustrator and for helping me with the graphics of the thesis.

Finally, I owe a debt to my parents who supported me honourably all these years. 


\section{Curriculum vitae}

I was born on 9th August 1973 as first child of Ekaterina Aleksandrovna Atlachkine (nee Belokopytova) and Vladimir Ivanovitch Atlachkine in Kvitok (Tayshetsky district, Irkutsk region of Russia).

From 1980 till 1983 I had my elementary education in a school in Sosnovoborsk (Krasnoyarsky region, Russia). In 1984 I joined a high school in Sosnovoborsk and successfully completed in 1990 with school-leaving certificate.

In the winter semester 1990 I started to study biology at the State University of Krasnoyarsk where I joined the department of ichtyology in 1992 for specialisation. I started my diploma thesis in summer 1994. In June 1995 I submitted my diploma thesis entitled "Ecological and morphological characteristics of fish of lakes Arachley and Shaksha (Chita region of Russia)" followed by an oral diploma examination.

In august 1995 I joined the ichtyology department of the Limnological Institute of Siberian Brunch Russian Academy of Sciences (Irkutsk, Russia) was joined for labrotation. In June 1996 I joined the molecular biology laboratory of the same institute was joined for labrotation, which I successfully finished in September 1997. From September 1997 till June 1998 I was working as research assistant in a project on "Philogenetic relationships of picoplanctonic green algae of the lake Baikal" in the molecular biology laboratory of the Limnological Institute.

From June 1998 till January 1999 I was holging a scholarship of the fund SATW (Swiss Academy of Technical Sciences) - Branco-Weiss. In that time I worked as a trainee at the Ecotoxicology laboratory for non-target arthropods (Novartis Crop Protection AG, Basel, Switzerland).

In February of 1999 I moved to Germany and started the $\mathrm{PhD}$ thesis presented here with the title "Characterisation of Vtilb and Vtila proteins and generation of knock-out mice" at the Georg-August University of Göttingen in the department of Prof. Dr. K. von Figura under the supervision of Dr. G. Fischer von Mollard. 